\title{
BIOREDUCIBLE POLY(AMIDO AMINE)S FOR SIRNA DELIVERY
}

\author{
PROEFSCHRIFT \\ ter verkrijging van \\ de graad van doctor aan de Universiteit Twente, \\ op gezag van de rector magnificus, \\ prof. dr. H. Brinksma, \\ volgens besluit van het College voor Promoties \\ in het openbaar te verdedigen \\ op woensdag I juni 2011 om I6.45 uur
}

door

Leonardus Joannes van der Aa

geboren op 3I oktober 1980

te Hengelo $(\mathrm{O})$ 
Dit proefschrift is goedgekeurd door:

prof. dr. J.F.J. Engbersen (promotor)

dr. R.M. Schiffelers (assistent promotor)

Dit werk is auteursrechtelijk beschermd

L.J. van der Aa

2OII

ISBN: 978-90-365-3184-9

2 
Samenstelling van de beoordelingscommissie:

Voorzitter: $\quad$ prof. dr. G. van der Steenoven

Universiteit Twente

Secretaris:

prof. dr. G. van der Steenoven

Universiteit Twente

Promotor: $\quad$ prof. dr. J.F.J. Engbersen

Universiteit Twente

Assistent promotor:

dr. R.M. Schiffelers

Universiteit Utrecht

Leden:

prof. dr. P.J. Dijkstra

Universiteit Twente

prof. dr. A.G.J.M. van Leeuwen

Universiteit Twente

prof. dr. K. Braeckmans

Universiteit Gent

prof. dr. R.G.H. Lammertink

Universiteit Twente 
The research in this thesis was carried out from 2006 until 2010 in the research group Biomedical Chemistry of the MIRA institute for Biomedical Technology and Technical Medicine, University of Twente, Enschede, The Netherlands.

\section{UNIVERSITY OF TWENTE.}

The research is supported by The Dutch Technology Foundation STW, which is part of the Netherlands Organisation for Scientific Research (NWO) and partly funded by the Ministry of Economic Affairs, Agriculture and Innovation (project number 07468).

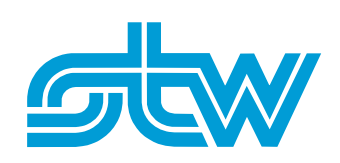

This thesis is further supported by PolyVation BV

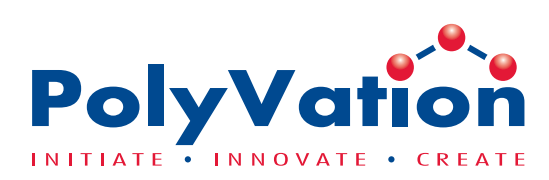

and 'De Nederlandse vereniging voor Biomaterialen en Tissue Engineering (NBTE)'

Cover design by Carolina Zayat

\section{carolinazayat.com}

Printed by Wöhrmann Print Service, Zutphen, The Netherlands 


\section{Voorwoord}

Klaar! Het onderzoek is gedaan en het proefschrift is af.

Voor het tot stand komen van dit proefschrift heb ik de afgelopen vier jaar een kleine 650 gram aan materialen gesynthetiseerd, een getal dat pas indrukwekkend wordt als je erbij vermeldt dat dat de gezamenlijke opbrengst is van 338 syntheses. Dat slechts 57 materialen uiteindelijk de eindstreep hebben gehaald en een plekje hebben gekregen in dit proefschrift, lijkt nogal teleurstellend, maar illustreert perfect wat het doen van onderzoek behelst: leren met vallen en opstaan. Ik heb inderdaad veel geleerd. Niet alleen op het gebied van synthese, maar ook op celbiologisch gebied heb ik veel kennis vergaard. Daarvoor ben ik veel mensen dank verschuldigd.

Allereerst bedank ik graag mijn promotor Johan Engbersen. Toen ik in de nazomer van 2006 op het IJsselmeer aan het nadenken was over de keuze tussen promoveren of bedrijfsleven, kwam er een verlossend telefoontje van jou. Je had twee vacante promotieplaatsen en na een bliksembezoek aan Enschede was ik meteen enthousiast. In een tweede gesprek hebben we de boel bezegeld en nog voor het einde van het jaar ben ik begonnen aan wat uiteindelijk dit proefschrift is geworden. Daarin vervulde jij een zeer goede dubbelfunctie als dagelijks begeleider en promotor. Ik vond het fijn dat ik te pas en te onpas je kantoor binnen kon lopen voor een vraag of probleem. Ik heb veel gehad aan je eindeloze chemische creativiteit, liefde voor reactiemechanismen en, met name gedurende de laatste loodjes, zeer zorgvuldige correcties van mijn manuscripten.

Hoewel de bovenstaande elementen essentieel waren voor mijn proefschrift, had het niet de huidige vorm gekregen zonder hulp van de overige staf van BMC of één van de andere PBM telgen. Allereerst Jan Feijen, bedankt voor alle inbreng, met name gedurende de maandagochtend presentaties. Als geestelijk vader van zowel alle uit PBM ontsproten groepen als van mijn universitaire loopbaan, vind ik het erg jammer dat je niet bij mijn promotie aanwezig kunt zijn en zitting kunt nemen in mijn promotie commissie. Piet, ook jij stond zes jaar geleden aan de wieg van bovengenoemde loopbaan en ik ben blij je als hooggeleerde opponent te mogen begroeten bij de afsluiting daarvan. Karin, zonder jouw wakend oog over alle administratieve processen (en over mijn sleutelbos) en je interesse in alle dagelijkse beslommeringen, was het leven als promovendus een stuk zwaarder geweest. Zlata, ik kon het zo gek niet bedenken en jij kon het bestellen! Bel je me als je gaat trakteren? Lekker, baklava! Hetty, op wetenschappelijk gebied hebben we niet zoveel samen gedaan, maar gelukkig was je ook erg vaardig in het verhelpen van mijn computerproblemen. Dirk, het was erg prettig om een kritisch polymeerchemicus in de buurt te hebben en André, voor jou gaat dezelfde

Voorwoord $\cdot \mathbf{5}$ 
vlieger op voor de celbiologie. Anita en Marc, dankzij jullie alertheid op de laboratoria heb ik daar vele uren veilig kunnen doorbrengen.

Ook de samenwerking met de projectpartners uit Utrecht heb ik als zeer prettig ervaren. Raymond, in chemie zijn wij in Twente erg goed, maar op het vlak van siRNA konden we nog een hoop bijleren. Daar heb jij de afgelopen jaren goed in voorzien en ik ben blij dat je ook als assistent promotor wil helpen mijn promotie tot een goed einde te brengen. Pieter, helaas heeft het noodlot van de muizen niet alleen de in vivo experimenten vroegtijdig beëindigd, maar ook opname daarvan in dit proefschrift verhinderd. Ik hoop dat je op korte termijn toch nog interessante resultaten zult boeken. Mies van Steenbergen wil ik hartelijk danken voor zijn kennis en bijdragen aan de GPC analyses.

Natuurlijk wil ik ook graag mijn studenten bedanken voor hun bijdragen. Jasmin, jij hebt de basis gelegd voor Hoofdstuk 5 . Leonie, jij hebt aan de wieg gestaan van Hoofdstuk 6 en 7. Gijs, Thomas en Jan, jullie hebben alle drie veel pionierswerk verricht voor de laatste twee hoofdstukken. Marieke, jouw werk is niet direct in dit proefschrift terug te vinden, maar heeft zeker veel kennis over PEGyleren opgeleverd, die we hebben gebruikt voor de polymeren voor in vivo werk.

Naast alle secundaire voorwaarden, was het voor mij zeker zo belangrijk dat ik elke dag met plezier naar mijn werk kon gaan. Niet alleen de vaak veel te lange koffie en lunchpauzes, maar ook alle borrels, barbecues, triatlons, de werkweken en niet te vergeten het zeilweekend zullen nog lang in mijn geheugen gegrift blijven. Een gezellige groep collega's was daar debet aan en een aantal van hen in het bijzonder. Martin, we volgen al ruim tien jaar het zelfde pad aan de universiteit en ik ben erg blij dat ik je tijdens onze promoties echt goed heb leren kennen. Bedankt voor alle interessante discussies op ons kantoor, in het lab, aan de koffie of in de auto naar Groningen. Hoewel we nu formeel geen collega's meer zijn, scheiden onze wegen niet heel ver van elkaar en ik hoop dat we elkaar nog vaak blijven tegenkomen. Niels, vooral op informeel vlak hebben we veel samen gedaan: de organisatie van de triatlon en werkweek, veel speciaalbier avonden en bovenal samen alles afzeiken. Fijn dat je nu als paranimf ook een formele rol kunt spelen in mijn promotie, tijdens de verdediging althans. Sytze, hoewel je menig bieravond verzaakte vanwege een afwijkend dag-, nacht- en drinkpatroon, hebben we ook veel parallellen. Samen op de middelbare school, dezelfde studie, beiden promoveren en allebei een Italiaanse auto, al hecht jij aan dat laatste iets meer waarde dan ik. Fijn dat ook jij als paranimf mijn promotie in goede banen wilt leiden. Andries, als bioloog was je altijd een makkelijke schietschijf, maar ik heb in het celkweeklab vaak dankbaar van je expertise gebruik mogen maken. Ook jij en Sjoerd deelden mijn liefhebberij voor speciaalbier, wat menig zondagavond heeft veraangenaamd. Siggi, vielen dank voor je positieve invloed op mijn Duits en je sociale betrokkenheid zowel op als buiten het werk. Erhan, als hardste werker die ik ook heb

6. Voorwoord 
gekend, bewonder ik het aantal borrels en andere activiteiten waar je altijd van de partij was. Jos, de laatste maanden initiator van onze deelnames aan de pubquiz, gelukkig ging je dat beter af dan een Sint Bernardus. Marloes en Kim, in het celkweeklab heb ik veel van jullie geleerd en ook jullie liefde voor rosé vrolijkte menig borrel op. Erwin, hoewel we maar een paar maanden echt collega zijn geweest, bracht je eindelijk weer wat nieuw leven in de brouwerij die langzaam leegliep. Ahhhh nee, ééécht, vergeet ik bijna Janine. Fijn dat jij af en toe wat vrouwelijke inbreng had in ons mannenclubje, al kan ik het niet laten om nog even te vermelden dat de speculaties over een relatie tussen A en $\mathrm{K}$ niet jou maar Niels en mij een krat bier hebben opgeleverd. Verder moeten hier zeker nog genoemd worden: Arkadi, Miguel, Chao, Rong, Christine, Mark ten B, Ingrid, Ferry, Frederico, Gregory, Sri Dewi, Jung Seok, Sandra de V, Vincent, Mark P, Sandra T, Di en Hongzhi.

Het klinkt een beetje raar, maar wat sommige mensen hebben met dieren, heb ik met oude huizen (en wat sommige mensen met huizen hebben, heb ik met dieren, maar dat terzijde). Daarom moet ik in deze paragraaf toch ook even mijn huis noemen. In het tweede jaar van mijn promotie heb ik een oud huis in Enschede gekocht, waar ik enorm veel aan heb gerestaureerd. Hoewel sommige mensen er niet aan moeten denken naast hun promotie, was het klussen voor mij echt een enorm fijne afleiding naast het onderzoek. Nu ga ik dan verhuizen en met heel veel pijn in mijn hart heb ik een 'te koop' bord op het raam geplakt.

Uiteraard verdient ook het thuisfront een plekje in dit hoofdstuk. Met enige afkeer las ik in deze passages altijd hoeveel steun de gemiddelde promovendus gedurende zijn promotie heeft aan zijn ouders. Papa en mama, hoewel jullie niet echt een actieve rol hadden in mijn onderzoek, is dat voor mij eigenlijk niet anders. lk heb een fijne jeugd gehad en jullie zijn er enorm goed in zijn geslaagd om mij te leren op mijn eigen benen te staan. Dat is een groot goed, waarzonder het denk ik onmogelijk is zoiets groots als een proefschrift af te maken en waar ik mijn hele verdere leven mee vooruit kan. Ronald en Marloes, jullie hebben daar als broer en zus misschien een wat onbewustere, maar minstens zo belangrijke rol in gespeeld. Leuk dat jij nu ook een gooi naar een doctorstitel gaat doen Marloes. Mama, sorry dat ik je wat promoveren betreft soms heb afgeserveerd met wikipedia, maar hopelijk vallen alle kwartjes woensdag I juni alsnog op zijn plaats. Papa, bedankt voor de bijna maandelijkse sociale controle op de Zuidhorst. Gelukkig kwam je ondanks de Autobar automaat toch steeds langs voor een kopje koffie.

Kyra, jij hebt jammer genoeg maar de helft van mijn promotie mee mogen maken. Sinds de zomer van 2010 zelfs nog van een stukje dichterbij. Hoewel dat in de optiek van 'meer tijd voor elkaar' niet het beste moment was om bij elkaar in te trekken, ben ik enorm blij dat je naar Enschede bent gekomen. Je hebt me uitstekend door het zwaarste deel van de promotie geloodst en ik ben er van overtuigd dat wij samen ook de rest van 
de wereld aan kunnen. Het eerste bewijsstuk hebben we daarvan denk ik al geleverd door samen naar Lelystad te verhuizen.

Hans

$8 \cdot$ Voorwoord 


\section{Contents}

Chapter 1 General introduction II

Chapter 2 Perspective on polymeric carrier systems for siRNA delivery I9

Chapter 3 Optimization of poly(amido amine)s as vectors for siRNA 47 delivery

Chapter 4 Optimizing the $\mathrm{p}(\mathrm{CBA}-\mathrm{ABOL} / \mathrm{EDA})$ system as polymeric 69 carrier for siRNA: fine-tuning of the charge density by small variations in the $\mathrm{ABOL} / \mathrm{EDA}$ ratio

Chapter 5 Optimizing the $\mathrm{p}(\mathrm{CBA}-\mathrm{ABOL} / \mathrm{EDA})$ system as polymeric 77 carrier for siRNA: tuning hydrophobicity by changing the alcoholic sidegroup

Chapter 6 Introducing pyridyl disulfides in p(CBA-ABOL/EDA) 95 crosslinking of polyplexes

Chapter 7 Introducing pyridyl disulfides in p(CBA-ABOL/EDA) - postII9 PEGylation of siRNA containing polyplexes

Chapter 8 Intercalating quaternary nicotinamide-based poly(amido I4I amine)s for gene delivery

Chapter 9 Intercalating poly(amido amine)s for gene delivery based on I65 quaternary nicotinamide derivatives

Appendix A Determining the molecular weight of poly(amido amine)s I87 by viscosimetry and the influence of molecular weight on the transfection efficiency

Appendix B Summary 2OI

Nederlandse samenvatting

Curriculum Vitae 


\title{
Chapter
}

\section{General introduction}

\author{
L.J. van $\operatorname{der} A a$ \\ P. Vader \\ R.M. Schiffelers \\ G. Storm \\ J.F.J. Engbersen
}

Part of this chapter is accepted for publication in: Current Topics in Medicinal Chemistry 


\subsection{Gene therapy}

The use of genes as medicine for both inherited and acquired diseases, gene therapy, gained an enormous interest over the last decades. Gene therapy relies on the on site treatment of diseases by the delivery of the specific gene of interest in the targeted tissue. Transcription of this gene results in the desired therapeutic effect, established by the production or blocking of production of specific proteins to cure the disease, induced by the delivery of DNA or RNA therapeutics, respectively. However, before widespread use of gene therapy in a clinical setting is possible, several hurdles have to be overcome. Due to the relatively large molecular weight and highly negative charge of the therapeutic nucleotides, they cannot readily cross cellular membranes. Furthermore, they are susceptible to degradation by endogenous enzymes, like serum nucleases, and rapidly cleared by the kidneys upon systemic administration [I]. At this moment, the success of gene therapy is dependent on delivery systems that modulate the pharmacokinetics and intracellular trafficking of the therapeutic genes. These systems should protect these genes against degradation, reduce distribution to nontargeted sites and facilitate cellular uptake at the targeted site.

Generally two classes of delivery systems can be distinguished, namely viral and non-viral carriers. Although viruses possess outstanding transfection efficacies, their application as therapeutic gene delivery vehicles have some inherent drawbacks as limited loading capacity, complicated large scale production and, most importantly, severe safety risks due to immunogenicity after repeated administration. This gives them only limited potential for broad clinical applications [2]. Non-viral delivery systems, which comprise cationic polymers and lipids, may circumvent some of the shortcomings of viruses. Although their efficiency is still inferior to their viral counterparts, substantial progress has been made in the last decade to develop and improve these delivery systems.

\subsection{RNA interference (RNAi)}

A relatively new development is the use of RNA interference (RNAi) in gene therapy. RNAi is an evolutionary conserved mechanism for regulation of gene expression in cells. Fire et al. discovered that introduction of double stranded RNA (dsRNA) can lead to silencing of gene expression in Caenorhabditis elegans [3]. Three years later, this phenomenon was also described in mammalian cells [4]. Since its discovery, RNAi has emerged as one of the most powerful tools in the study of functional genomics and offers hope as a new therapeutic strategy for various diseases, including cancer.

12. Chapter 1 

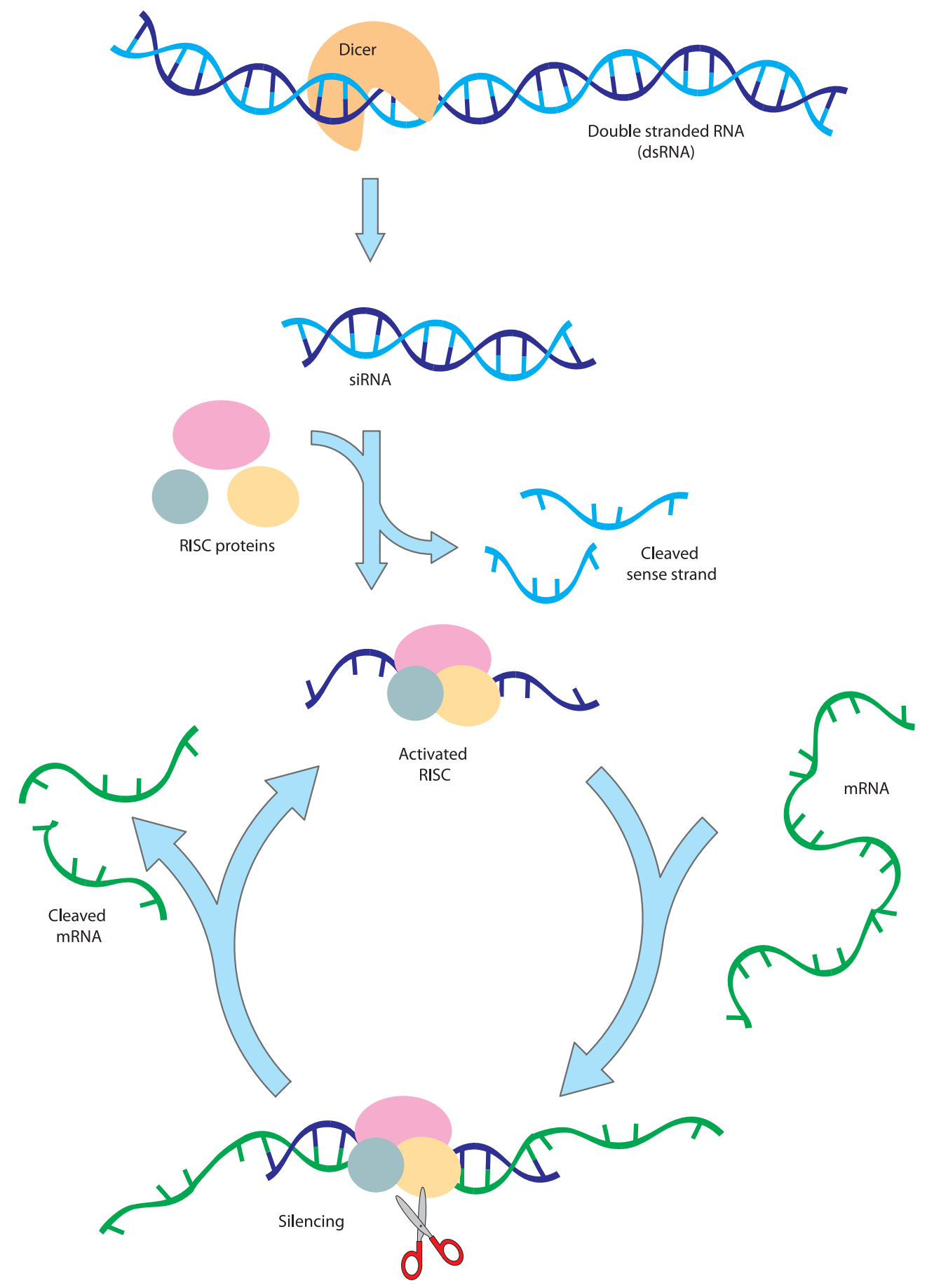

Figure 1.1: Schematic representation of the RNA interference process using siRNA. 
The RNAi response is triggered by dsRNA present inside cells (Figure I.I). The dsRNA is recognized by Dicer, a RNAse Ill-type enzyme, which cleaves it into short fragments of approximately $2 \mathrm{I}-23$ nucleotides long, also known as small interfering RNA (siRNA) [5]. The siRNA is then incorporated in the RNA-induced silencing complex (RISC), which becomes activated, cleaves the sense strand of the siRNA and is guided by the antisense strand to degrade mRNA that is recognized via complementary basepairing [6]. The antisense-loaded RISC can then move on to destroy additional mRNAs, which makes RNAi via RISC a powerful catalytic event [7]. siRNAs can easily be produced synthetically and then directly introduced into cells by use of a suitable gene carrier system. Theoretically, any gene can be silenced when the siRNA is properly designed, which gives the application of RNAi with siRNA a very broad therapeutic potential.

\subsection{Poly(amido amine)s}

Cationic polymers appeared to be good candidates as gene delivery materials, since they interact electrostatically with negatively charged nucleotides, resulting in the spontaneous formation of nanosized polymer/nucleotide

complexes (polyplexes). Typical polymers that have been explored to encapsulate and deliver siRNA are linear and branched poly(ethyleneimine) (PEI), poly(L-lysine) (PLL), chitosan, linear poly(amido amine)s (PAA), linear poly(amido
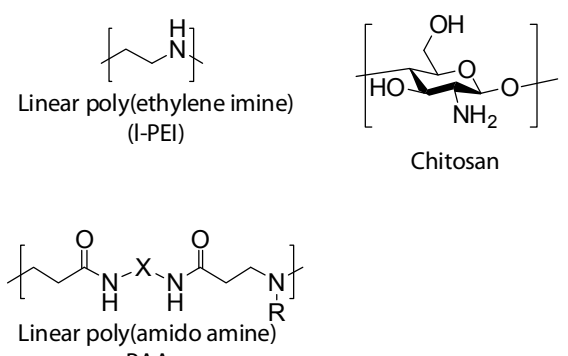

$$
\text { PAA }
$$

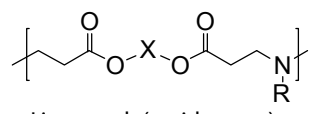

Linear poly(amido ester) PAE

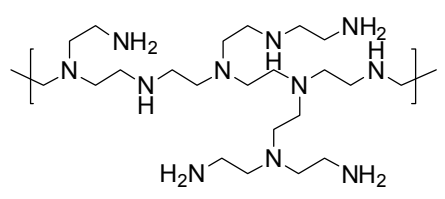

Branched poly(ethylene imine) (b-PEI)

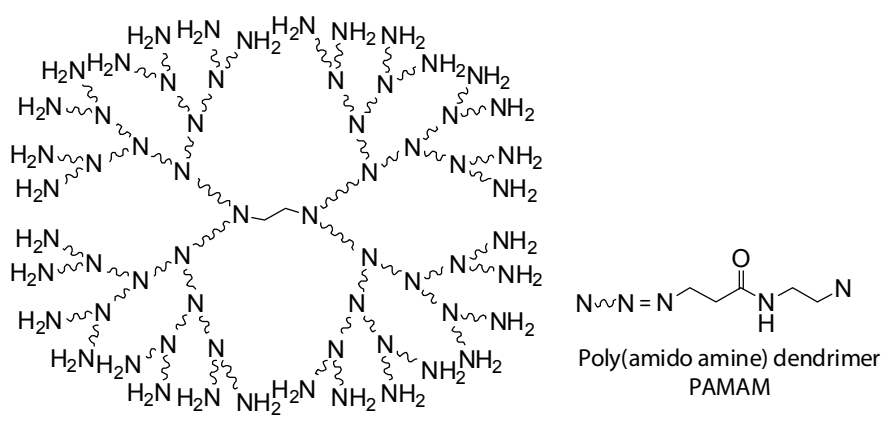

Figure 1.2: Structures of frequently used polymers for siRNA complexation.

$14 \cdot$ Chapter 1 
ester)s (PAE) and poly(amido amine) dendrimers (PAMAM) and their structural representations are shown in Figure I.2 [8-13]. Most systems are however hampered by low transfection efficiencies, usually related to poor plasma stability, endosomal uptake and escape and polyplex unpacking. Many systems also show a high cytotoxicity, frequently associated with the non-degradable character of the polymer.

Linear poly(amido amine)s are versatile polymers with a peptidomimetic structure, which are easily synthesized in a Michael type addition polymerization from amines with bisacrylamides (Scheme I.I). The versatility of these polymers originates in the wide range of specific functionalities (X, R, R' or R" in Scheme I.I) that can be included in the polymer by applying a plethora of different monomers, provided that they contain acrylamide or amine functionalities. The basic tertiary amines in the polymer backbone provide the polymer its cationic character. Poly(amido amine)s are generally good water soluble, low cytotoxic and degradable in aqueous solutions by means of hydrolytic cleavage of the amidic bonds [14]. Especially the incorporation of a disulfide bond in the bisacrylamide monomer increases the intracellular degradation of these polymers enormously by a cytosolic disulfide reduction reaction, resulting in enhanced transfection efficiencies and decreased cytotoxicities [I5-I6]. All these properties make this class of polymers an excellent candidate for gene delivery applications.

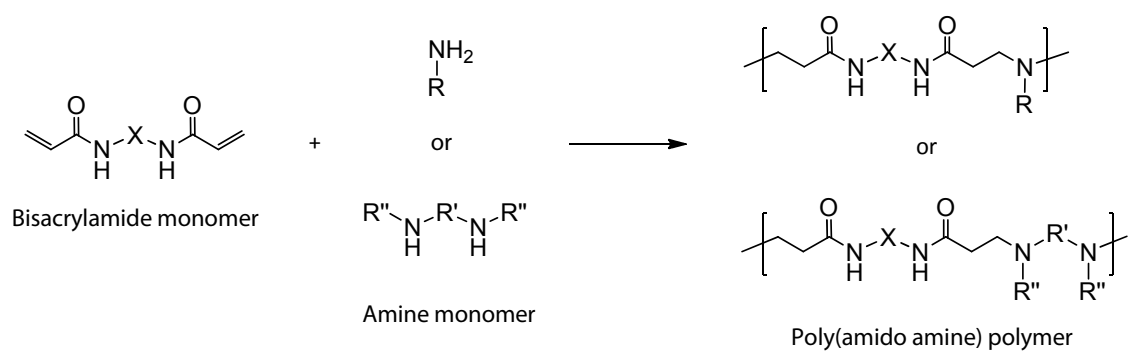

Scheme 1.1: General synthesis of linear poly(amido amine)s by Michael addition polymerization between bisacrylamide and amine compounds.

\subsection{Objective}

In the previous decade many successes were booked with the development of poly(amido amine) based carriers for plasmid DNA delivery [15-I9]. The aim of this study is to adapt and further improve these successful systems for siRNA delivery and to optimize them for gene silencing applications. Therefore, structure function relationships of these polymers were systematically investigated to optimize 
complexation of small polynucleotides, provide maximal stability in physiological media, maximize gene silencing efficiency and reduce cytotoxicity.

\subsection{Outline of the thesis}

In this thesis the development of bioreducible poly(amido amine)s (SS-PAAs) for the intracellular delivery of siRNA is reported. In Chapter $\mathbf{2}$ the progress in the global research on polymeric carriers for siRNA, as reported in scientific literature, is outlined with the aim to give an overview of the complete process of polymeric siRNA delivery and to understand the problems that are currently encountered. A description of the research in this thesis is started in Chapter $\mathbf{3}$ where an already successfully used SS-PAA in DNA delivery, is explored for siRNA delivery. The cationic charge density in this polymer was varied and increased by the introduction of (protonatable) diamino ethylene units to improve the interaction between the polymer and siRNA molecules to form small and stable polyplexes. The effects of the introduction of extra cationic charge units was evaluated for cellular uptake, in vitro gene silencing, and cytotoxicity. The fine-tuning of the charge balance in the most promising polymer is further described in Chapter 4, and a description of the optimization of the hydrophilic/lipophilic balance of the resulting polymer is given by increasing the spacer length of the lipophilic alcohol side chain in Chapter 5. The effects of hydrophobicity on polyplex formation, membranolytic ability, gene silencing and cytotoxicity have been investigated. The best performing SS-PAA, resulting from Chapter 3, 4 and 5, has been selected for further research and this polymer was equipped with pyridyl disulfide side groups, as described in Chapter 6. These groups can be used for post-modification by thiol functionalized molecules, resulting in a reversible modification via a bioreducible disulfide linker. Preformed siRNA containing polyplexes are stabilized in a postcrosslinking reaction with a bifunctional thiol molecule as a first step towards in vivo application, resulting in cage-like polyplex structures. The influence of the crosslinking degree on the particle properties and gene silencing are studied extensively. In Chapter 7 the same pyridyl disulfide containing SS-PAAs are subsequently described in their use for post-PEGylation by thiol functionalized PEG chains as a second step to prepare siRNA complexes that are stable under in vivo conditions. The influence of PEGylation degree and PEG chain length on particle properties, nuclease protection and gene silencing have been examined in detail. The development of a novel SS-PAA for nucleic acid complexation is described in Chapter 8. Complex formation with this polymer relies, next to electrostatic interactions, on intercalative interactions between quaternary nicotinamide side chains and double stranded nucleic acids like siRNA and DNA. By varying the quaternary nicotinamide content in the polymer, the effect of

$16 \cdot$ Chapter 1 
intercalation has been studied on polyplex formation and stabilization, gene silencing, gene expression and cytotoxicity. Chapter 9 describes the effects of the intercalation capacity of the quaternary nicotinamide by using different structurally related nicotinamide derivatives. The relative intercalation capacity of these derivatives was measured and their effects on polyplex formation, cellular uptake, gene silencing and gene expression were studied in detail. Appendix A finally describes a method to determine the molecular weight of SS-PAAs by viscosimetry and also demonstrates the effect of the polymer molecular weight on particle formation and gene silencing properties.

\subsection{References}

I. de Fougerolles, A., et al., Interfering with disease: a progress report on siRNAbased therapeutics. Nat Rev Drug Discov, 2007. 6(6): p. 443-53.

2. Aigner, A., Delivery systems for the direct application of SiRNAs to induce RNA interference (RNAi) in vivo. Journal of Biomedicine and Biotechnology, 2006: p. I5.

3. Fire, A., et al., Potent and specific genetic interference by double-stranded RNA in Caenorhabditis elegans. Nature, I998. 391(6669): p. 806-II.

4. $\quad$ Elbashir, S.M., et al., Duplexes of 2I-nucleotide RNAs mediate RNA interference in cultured mammalian cells. Nature, 200I. 4II(6836): p. 494-8.

5. $\quad$ Bernstein, E., et al., Role for a bidentate ribonuclease in the initiation step of RNA interference. Nature, 200I. 409(68I8): p. 363-6.

6. $\quad$ Martinez, J., et al., Single-stranded antisense siRNAs guide target $R N A$ cleavage in RNAi. Cell, 2002. IIO(5): p. 563-74.

7. Hutvagner, G. and P.D. Zamore, $A$ microRNA in a multiple-turnover $R N A i$ enzyme complex. Science, 2002. 297(5589): p. 2056-6o.

8. de Martimprey, H., et al., Polymer nanocarriers for the delivery of small fragments of nucleic acids: Oligonucleotides and siRNA. European Journal of Pharmaceutics and Biopharmaceutics, 2009. 7I(3): p. 490-504.

9. Zhang, S.B., et al., Cationic lipids and polymers mediated vectors for delivery of siRNA. Journal of Controlled Release, 2007. I23(I): p. I-Io.

Io. Kim, W.J. and S.W. Kim, Efficient siRNA Delivery with Non-viral Polymeric Vehicles. Pharmaceutical Research, 2009. 26(3): p. 657-666.

II. Doody, A. and D. Putnam, RNA-interference effectors and their delivery. Critical Reviews in Therapeutic Drug Carrier Systems, 2006. 23(2): p. I37-I64.

I2. Vanden-Broucke, R.E., et al., Prolonged gene silencing in hepatoma cells and primary hepatocytes after small interfering $R N A$ delivery with biodegradable poly(beta-amino esters). Journal Of Gene Medicine, 2008. Io(7): p. 783-794.

I3. Yin, Q., et al., Bioreducible poly ([beta]-amino esters)/shRNA complex nanoparticles for efficient RNA delivery. Journal Of Controlled Release. In Press, Corrected Proof. 
I4. Ferruti, P., M.A. Marchisio, and R. Duncan, Poly(amido-amine)s: Biomedical applications. Macromolecular Rapid Communications, 2002. 23(5-6): p. 332-355.

I5. Piest, M., et al., Novel poly(amido amine)s with bioreducible disulfide linkages in their diamino-units: Structure effects and in vitro gene transfer properties. Journal of Controlled Release, 2008. I30(I): p. 38-45.

I6. Lin, C., et al., Novel Bioreducible Poly(amido amine)s for Highly Efficient Gene Delivery. Bioconjugate Chemistry, 2007. I8(I): p. I38-I45.

I7. Lin, C., et al., Linear poly(amido amine)s with secondary and tertiary amino groups and variable amounts of disulfide linkages: Synthesis and in vitro gene transfer properties. Journal of Controlled Release, 2006. II6(2): p. I30-I37.

I8. Mateos-Timoneda, M.A., et al., Poly(amido amine)s as Gene Delivery Vectors: Effects of Quaternary Nicotinamide Moieties in the Side Chains.

ChemMedChem, 2007. 3: p. 478-486.

I9. Christensen, L.V., et al., Reducible poly(amido ethylenimine)s designed for triggered intracellular gene delivery. Bioconjugate Chemistry, 2006. I7(5): p. I233-I24O. 


\title{
Chapter
}

\section{Perspective on polymeric carrier systems for siRNA delivery}

\author{
L.J. van $\operatorname{der} A a$ \\ P. Vader \\ R.M. Schiffelers \\ G. Storm \\ J.F.J. Engbersen
}




\begin{abstract}
RNA interference is a relatively new approach in gene therapy and is considered to be very promising, since - in contrast to therapeutic DNA - a nuclear entry is not necessary for the interfering therapeutic polynucleotide in order to be effective. However, successes in (pre-) clinical studies are still limited due to the lack of efficient delivery systems for the mediator, small interfering RNA (siRNA), to the targeted site. The key to success can be the delivery of the siRNA molecules by polymer-based vectors, since these systems can be chemically tailored for efficient siRNA protection and intracellular delivery. Although results with polymeric vectors are increasingly encouraging, there are still many hurdles to be tackled towards clinical application. Insight into the polymer structure / function relationships in siRNA complexation / decomplexation, cellular delivery, intracellular trafficking and pharmacokinetics will help to design and optimize better delivery systems. This chapter describes the complete route from siRNA complexation to in vivo delivery of siRNA with the use of polymeric carriers, thereby extensively illustrated with examples from recent literature.
\end{abstract}

\title{
2.1 Introduction
}

The concept of treating an innumerable amount of diseases by the use of gene therapy, and especially by RNA interference (RNAi), is very promising. In theory, by using RNAi gene therapy, diseases like cancer can be treated on exactly the right location in the body, without side effects to other tissue. The process of RNAi gene therapy mainly involves the transfer of the therapeutic siRNA into the cells of the target tissue. However, the simple administration of an siRNA solution is no option, since the negatively charged nucleotides are not readily taken up by the cells and are rapidly degraded by omnipresent nucleases. To protect the siRNA on its way to the targeted site and to stimulate cellular uptake, a cargo material is necessary. Viruses are highly specified in the delivery of genes, but are actually no option due to safety considerations as described in Chapter I. Cationic lipids and polymers are good alternatives for viruses and the delivery of siRNA with cationic polymers is discussed in this chapter.

In Figure 2.I the complete process of siRNA transfection using cationic polymers is illustrated schematically. In brief, siRNA is first mixed with cationic polymers to spontaneously form nanosized polymer/siRNA complexes (polyplexes) by electrostatic interactions. These polyplexes protect the siRNA molecules against enzymatic degradation and enhance cellular uptake by endocytosis. Furthermore, these polyplexes can be supplied with particular ligands (not shown in Figure 2.I) to make them cell specific and bind them to the targeted cells. After endocytosis, the polyplexes have to escape the endolysosomal pathway to be effective in the cytosol and to prevent

20 . Chapter 2 
degradation in the lysosomes. When the polyplexes are escaped into the cytosol, the siRNA molecules have to be released by polyplex dissociation at the area of destination and become available for the RNAi process. Finally, degradation or exocytosis of the cationic polymer will clean up the residual cationic polymer. In this chapter all the steps and the corresponding difficulties in the polyplex formation and cellular delivery of siRNA are described extensively. Each step is supplied with an overview of creative innovations in the polymeric gene delivery systems reported in the recent literature. Although the delivery of siRNA parallels the delivery of DNA to a large extent, in this chapter we will primarily focus on applications with siRNA.

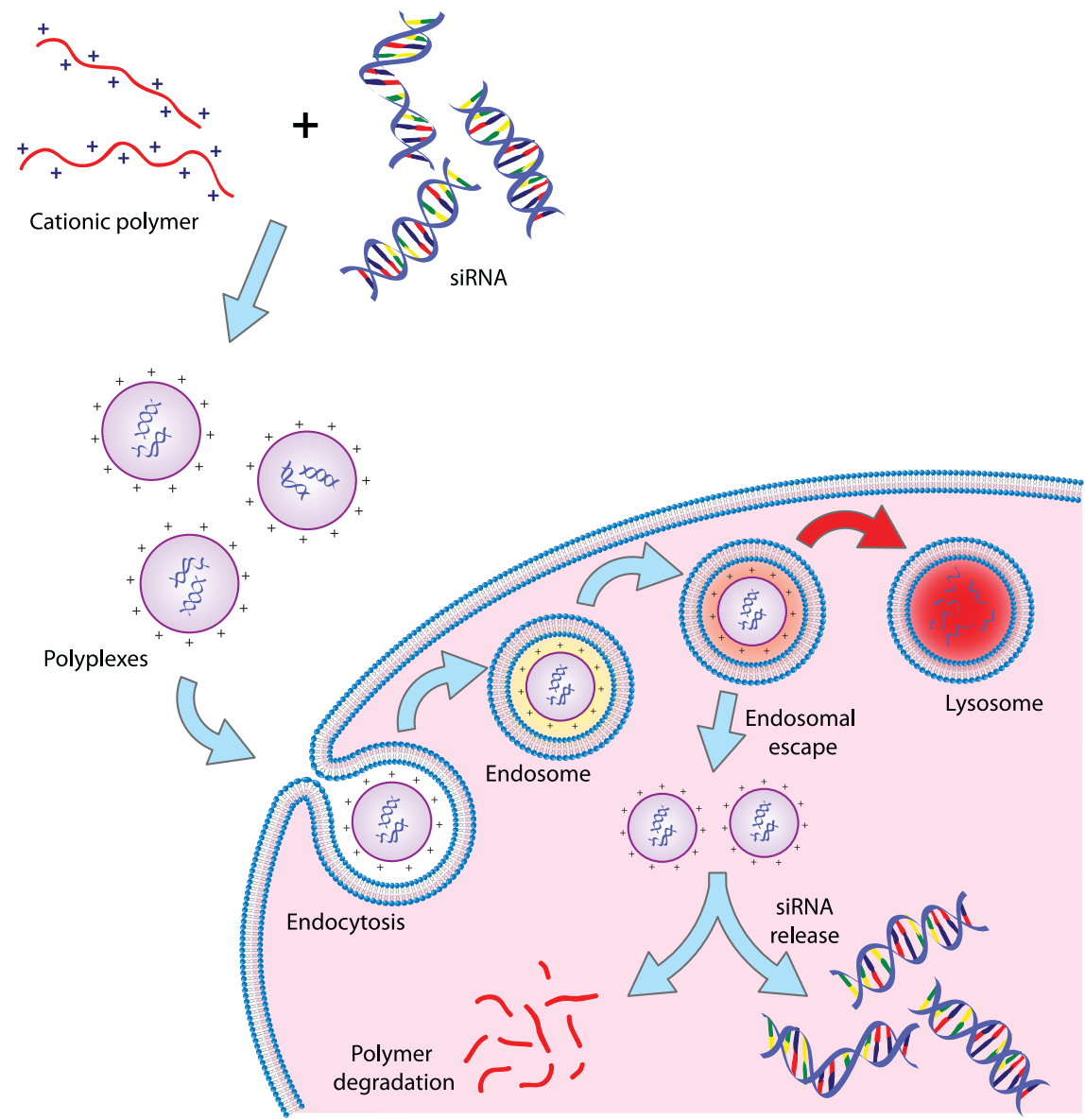

Figure 2.1: Schematic representation of the siRNA transfection process. 


\subsection{Formation of siRNA-polymer nanoparticles (polyplexes)}

The first polymeric systems that were investigated for siRNA delivery were derived from systems that have shown to be successful in plasmid DNA (pDNA) delivery. However, there are some fundamental differences between siRNA and pDNA, which makes a simple replacement of pDNA by siRNA in a delivery system not as straightforward as it might seem. The huge difference in number of nucleotides in pDNA (usually several thousand base pairs long) and siRNA (only 2I-27 base pairs), and therefore also the amount of negatively charged sites in these molecules, makes the interactions with polymers distinctly different. In pDNA polyplexes, many cooperative interactions can be formed between these two types of oppositely charged macromolecules with only limited loss of translational and conformational entropy in these macromolecules. Thereby, the condensed folding of the pDNA in these complexes provides many spatial possibilities to optimize DNA-polymer interactions. In contrast, siRNA molecules behave like rigid rods [2] and this absence of spatial flexibility poses high constraints on the formation of cooperative interactions with the polymer. Compared to pDNA, with siRNA less cooperative interactions with the polycationic polymer are possible and these interactions occur with higher loss of rotational (polymer) and translational (siRNA and polymer) entropy. These weaker intermolecular forces can lead to incomplete siRNA complexation or excessive size and poor stability of the formed complexes [3]. Creative strategies have already been applied to use existing DNA transfection reagents with siRNA. Complementary sticky overhangs of adenine and thymine were introduced by Behr et al. to reversibly concatemerize the siRNA molecules to make them gene like (ssiRNA) [4], and in the lipoplex field siRNA was cocomplexed with long carrier DNA that serves as an entangler in the complex [5-6].

The complex formation between siRNA and the polymer molecules is usually based on opposite charge attraction between the anionic polynucleotide and the cationic polymer. This process is favorable because of the entropic gain upon the release of bound counterions $[7-8]$ and water molecules due to reduced hydration. The stability of the polyplexes can be improved by combining the coulombic interactions with for instance intercalation [9], hydrogen bonding [IO] and hydrophobic interactions [II-I2]. Moreover, after formation of polyplexes, they can be additionally stabilized by crosslinking of the complexed polymer to create a polymeric network around the entrapped siRNA molecules [13-I5]. Additional parameters, like molecular weight and polymer architecture (linear or branched), which are known to be of effect in the transfection process do not seem to significantly influence the siRNA-polymer complexation process [16-I7]. 


\subsection{Cellular uptake of polyplexes}

Polyplexes are taken up by the cells by endocytosis after interaction with the cellular membrane, which can be specific or non-specific. Specific interactions are usually receptor-mediated, which requires the polymer to be functionalized with a specific ligand for this receptor. Examples are functionalization with transferrin or folic acid for tumor targeting. Non-specific interactions are generally based on electrostatic forces between the cationic polymer and negatively charged sulfated proteoglycans, like heparan sulfate, present on the cellular membrane [I8].

After the initial binding, cells possess different endocytotic uptake pathways for non-specific endocytosis, like clathrin and caveolae mediated endocytosis, macropinocytosis or phagocytosis [19-20]. However, cellular internalization routes are a turbulent research field and at present it is not clear how siRNA complexes are exactly taken up. Studies of uptake routes of polymeric siRNA particles are hard to find in literature. Only a few studies investigating the uptake of pDNA complexes have been reported [2I-23], but it is difficult to draw general conclusions for siRNA complexes from those results.

\subsection{Endosomal escape of siRNA polyplexes}

Internalization of polyplexes after binding to the cell receptor of cell membrane starts with invagination of the cell membrane and closure of the membrane to form small vesicles, called endosomes. Endosomes are transporter compartments, which either recycle the internalized molecules back to the cell surface or transform to late endosomes and finally fuse with lysosomes. Owing to the digestive function of the lysosomes, they have an acidic nature and contain several degrading enzymes. This milieu is not favorable for nucleotides. Therefore it is highly important that the polyplexes (or their cargo) escape from the endosomes before externalization or degradation occurs in the lysosomes. Different theories about possible escape mechanisms are currently pursued in literature. Although there is still some debate on the exact mechanism, there are strong indications that polymers which possess good buffering properties between $\mathrm{pH} 5$ and 7.4 positively correlate with good endosomal escape properties.

An important theory about the action of the polymer in the endosomal escape process is the proton sponge hypothesis, as is schematically illustrated in Figure 2.2. This hypothesis was firstly postulated by Behr and coworkers, using PEI or a lipopolyamine [24-25]. According to this theory, the (unprotonated) basic sites of the cationic polymers act as buffer moieties by taking up the protons that are pumped in the endosomes on the way from endocytosis towards fusion with lysosomes. As a result 
of this $\mathrm{pH}$ buffering by the polymer, the endosomal ATPases have to pump in extra protons to reach the lysosomal $\mathrm{pH}$. This proton influx simultaneously leads to an influx of chloride counterions. As a consequence of the increased osmolarity, an osmotic swelling occurs, which is believed to cause the rupture of the endosomal membrane, releasing the polyplexes into the cytosol.

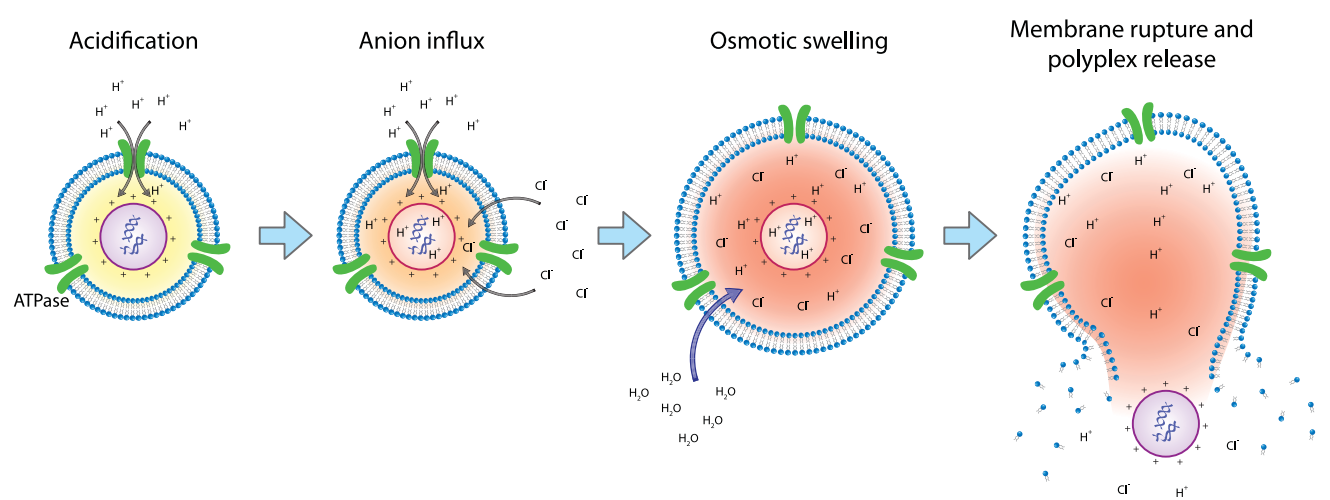

Figure 2.2: Schematic representation of the proton sponge effect.

Although this theory offers a reasonable explanation for the endosomal escape of polymers that buffer in the endosomal $\mathrm{pH}$ range, the proton sponge theory remains under debate. Funhoff et al. measured a decrease instead of an expected increase in gene expression by improving the buffer capacity of pDMAEMA with the incorporation of an extra amine in the side chain (pDAMA) [26]. Godbey et al. monitored the $\mathrm{pH}$ of the endosomes and lysosomes with fluorescent $\mathrm{pH}$ indicators in PEI-mediated transfection studies [27]. Based on absence of a $\mathrm{pH}$ change in the lysosomes they concluded that there was no evidence for a proton sponge escaping mechanism. Oppositely, Sonawane et al. demonstrated a high chloride accumulation after endocytosis of the buffering polymers PEI and PAMAM and a sharp decrease of chloride after one hour, suggesting a release of the polyplexes as postulated in the proton sponge hypothesis [28]. In addition, PLL, which is a poor buffering polymer, did not show high chloride accumulation.

For polymers lacking a high buffer capacity, chloroquine is added frequently to the cell culture medium to enhance endosomal escape. Although chloroquine is known for boosting the buffer capacity, Cheng and coworkers unraveled the exact mechanism by synthesizing chloroquine analogues with subtle structural changes [29]. Although they performed their study with pDNA, the outcome is also very useful for siRNA. Chloroquine accumulates in endocytotic vesicles up to concentrations of Ioo times the concentration in the medium. The acidic nature of these vesicles leads to protonation of the uncharged chloroquine, preventing membrane crossing [30]. The high concentration of chloroquine in the endosomes is not only responsible for the increased

24 - Chapter 2 
buffering, but even promotes the unpacking of the polyplexes. Since the quinoleic part of chloroquine can intercalate in double stranded nucleotides, it will compete in charge neutralization of the polynucleotide with the cationic polymer and hence destabilize the polyplexes. Cheng postulates that chloroquine intercalation of pDNA prevents degradation on its way to the nucleus. However, whether such intercalation would interfere in the silencing process in case of siRNA has not been investigated thus far. In the end, polymers that are endosomolytic by themselves are strongly in favor to polymers that require chloroquine, since chloroquine potentially disrupts every endosomal vesicle in the cell. Furthermore, systems that require the use chloroquine will never be applicable in vivo and are therefore clinically not relevant.

Besides causing endosomal swelling, others have argued that the increasing cationic character of the polymers upon endosomal acidification causes increased interaction with the endosomal membrane, leading eventually to membrane disruption and lysis. Fischer et al. showed the membranolytic ability of several frequently used cationic polymers by measuring LDH release from L292 mouse fibroblasts [I6]. Both PEI and PLL showed a LDH release of almost 50\% for low polymer concentrations (O.OI $\mathrm{mg} / \mathrm{ml}$ ) over I hour. In contrast, PAMAM and amine modified dextran did not show significant $\mathrm{LDH}$ release, even at $\mathrm{I} \mathrm{mg} / \mathrm{ml}$. Similar behavior for these polymers was observed by Hong et al. in $\mathrm{KB}$ and Rat 2 cells [3I]. A correlation with the transfection efficiency was not given in these studies, since they used polymer solutions without the presence of RNA or DNA.

A pH-dependent membranolytic behavior was shown by Miyata et al. [32]. They prepared PEG-poly(aspartic acid) copolymers, functionalized with diethylenetriamine (PAsp(DET)) side chains. The ingenuity of this system is that the primary and secondary amine of DET share a proton at physiological, resulting in the gauche conformation (Scheme 2.I). At $\mathrm{pH} 5$ both amines are individually protonated, resulting in the energetically more favorable anti conformation. $\mathrm{LDH}$ release and hemolysis experiments demonstrate only membrane interaction at $\mathrm{pH} 5$, thus for the protonated anti conformation. It was not clarified whether this destabilization behavior was due to the conformational change or to the higher charge density at low $\mathrm{pH}$, but it is clear that (branched) PEI contains analogous structures and such conformational changes in PEI may also beneficially contribute to the escaping properties of PEI. Recently, the PAsp(DET) carrier was improved with additional stearoyl moieties, resulting in a better membrane penetration and hence a further improved endosomal escape [33]. In the field of lipidic carriers, Wang et al prepared a surfactant (EHCO) containing an ethylene diamine in the headgroup [34]. Although they did not attribute their observations to the conformational change upon the second protonation, they observed a similar $\mathrm{pH}$ dependent membranolytic behavior for this surfactant. Haag and coworkers synthesized a polyglycerolamine and attributed the good nucleotide binding, high gene 
silencing and low cytotoxicity also to the shared protonation of the 1,2-diaminounits [35].

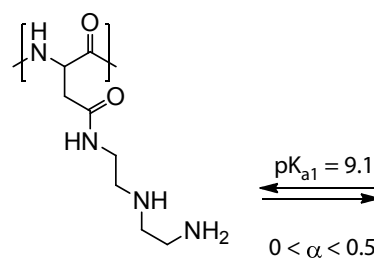

gauche $\sim 80 \%$

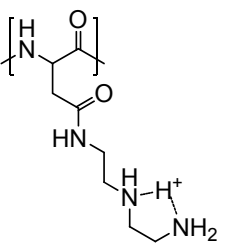

gauche

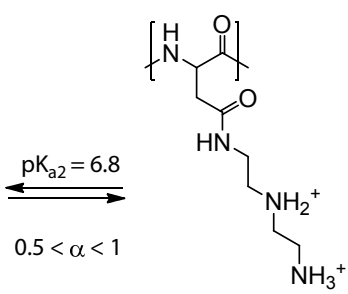

anti

Scheme 2.1: Membranolytic protonation behavior of the diethylenetriamine (DET) side groups on PEGpoly(aspartic acid) copolymers [32]. $a$ is the total fraction of protonation of the DET sidegroup.

Xiong et al. modified a biodegradable amphiphilic poly(ethylene glycol)-blockpolyester with three different polyamines (spermine (SP), tetraethlyenepentamine (TP), and $N, N$-dimethyldipropylenetriamine (DP)) to introduce cationic charge and endosomal escape properties (Figure 2.3) [I]. All materials formed small polyplexes, but only the polymers possessing side chains with terminal primary amines yielded silencing. This was attributed to the ability to penetrate membranes at low $\mathrm{pH}$. Knockdown values of $50-60 \%$ were achieved by silencing P-glycoprotein on MDA435/LCC6 tumor cells and were comparable with b-PEI. The endosomal escape for SP and TP modified polymers occurred in a similar time span. However, the authors did not clarify if there was a difference in buffer capacity or lytic activity at

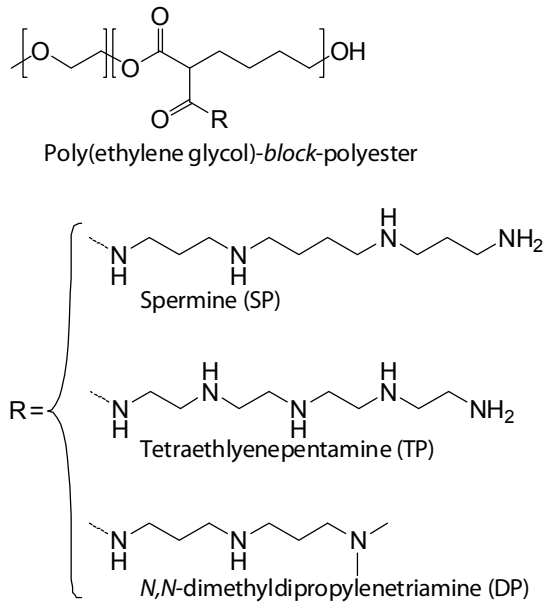

Figure 2.3: General structure of polyamine grafted poly(ethylene glycol)-blockpolyester as they were prepared by Xiong [1]. $R$ represents the polyamines spermine (SP), tetraethlyenepentamine (TP) or $\mathrm{N}, \mathrm{N}$ dimethyldipropylenetriamine (DP). low $\mathrm{pH}$, so the successful endosomal escape cannot be assigned exclusively to one of those parameters.

Fusogenic peptides are sometimes used to enhance endosomal escape. However, these studies have mainly focused on siRNA-peptide conjugates, although a few examples have been described of such systems in combination with polymers. HGP, a lytic peptide from the endodomain of HIV envelope gp4I, was coupled to branched PEI

26. Chapter 2 
with a molecular weight of $25 \mathrm{~kg} / \mathrm{mol}$ by Kwon et al. [36]. Increased silencing of GAPDH in HeLa cells was reported for HPG-modified PEI (82\%) in contrast to nonfunctionalized PEI (53\%). Complex internalization, analyzed with fluorescently labeled complexes, was identical for modified and unmodified PEI, but confocal images showed a lower extent of colocalization of the HGP-modified complexes with endosomes after 3 hours. These results illustrate that HGP-PEI specifically penetrates endosomal membranes. The membranolytic melittin, a major bioactive component of bee venom, was used ingeniously by Meyer et al. [37]. Toxic extracellular membrane interactions were eliminated by protecting the primary amines on melittin with dimethylmaleic anhydride (DMMAn). This pH-labile protecting group is released upon acidification in the endosomes, resulting in a reactivation of the membranolytic capability of the peptide. The protected melittin was coupled reversibly to PLL-PEG and branched PEIPEG copolymers via a disulfide linker (Figure 2.4). Melittin modified polyplexes greatly enhanced the luciferase knockdown in luciferase expressing Neuro 2A-eGFPLuc cells. PEI-PEG-DMMAn-Mel achieved 60\% knockdown versus $20 \%$ for PEI -PEG and 50\% for PEI only. PLL-PEG-DMMAn-Mel accomplished even 90\% knockdown, where PLL PEG and PLL only did not show any significant knockdown. In a later study of the same group the PLL-PEG-DMMAn-Mel system appeared to dissociate in the presence of low concentrations of heparin [38]. Reversible conjugation of the siRNA to the PLL via a disulfide linker prevented this dissociation and did not affect the silencing properties.

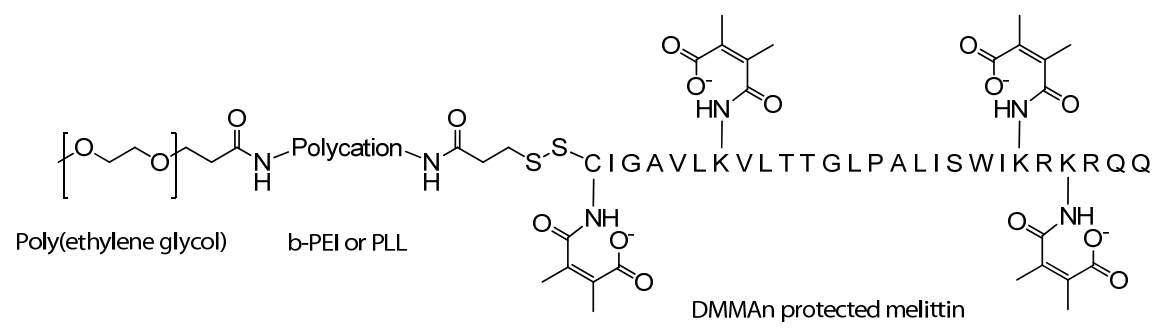

Figure 2.4: Schematic structure of melittin functionalized polycation (PEG-b-PEI or PEG-PLL). The dimethylmaleic anhydride protecting groups (DMMAn) are released upon acidification, restoring the lytic activity of melittin after endocytosis.

\section{5 siRNA release from polyplexes}

Since polyplex formation is a spontaneous process that is entropically driven by the release of bound water molecules and counterions, it is unlikely that the complexes will dissociate spontaneously after endosomal escape. However, the cytosolic environment plays a major role in vector unpacking. PEI and dendritic PLL polyplexes were exposed 
to cytosolic liquid by Okuda et al. [39]. The polyplexes dissociated at low polymer concentrations and this was attributed to interactions of the polymers with cytosolic proteins. Huth and coworkers performed comparable experiments, and concluded that interactions with cytosolic RNA were mainly responsible for the dissociation [40]. Irrespective of the compounds causing polyplex dissociation, the unpacking is relatively slow and to a certain degree reversible. Release of siRNA by polymer degradation is much faster and irreversible. It has been shown that incorporation of hydrolysable or reducible linkers in the polymer chain can boost transfection efficiencies significantly.

The disulfide moiety is one of the most popular reducible linkers and this group can be reductively cleaved by reaction with thiol reagents like the biologically active reducing agent glutathione. Since the glutathione concentration in the intracellular space is three orders of magnitude higher than in the extracellular environment [4I-42], disulfide-containing polymers are relatively stable in the transport phase to the cell, but will be rapidly degraded in the effector phase within the cytosol. An additional advantage of the separation into small polymer fragments is the decreased cytotoxicity of the polymer [43]. The positive effects of disulfide linkages in poly(amido amine)mediated gene delivery are extensively explored by our group and in literature [44-49], and in this thesis we will show that these versatile polymers can also be engineered for siRNA delivery. A reducible branched PEI (SS-PEI) (Figure 2.5a) was synthesized by Breunig by introducing disulfides via crosslinking linear low molecular weight PEI (2.6 $\mathrm{kg} / \mathrm{mol}$ ) with $3 \%$ Lomant's reagent [50]. Silencing ability of this polymer was measured by knocking down EGFP in CHO-KI cells. Although the silencing was slightly lower than with branched PEI (55\% versus $75 \%$ ), confocal laser scanning images indicated that SS-PEI indeed promotes the intracellular release of siRNA. Furthermore, significantly lower toxicity was observed for SS-PEI compared to non-reducible b-PEI.

A poly(amido ethyleneimine) PAEI was used by Jeong et al. to have PEI-like structures in a reducible amide backbone (Figure 2.5b) [5I]. VEGF in PC-3 cells was targeted in the in vitro knockdown studies. At polymer/siRNA weight ratio 6 and $\mathrm{I} 2$, the concentration of secreted VEGF in the supernatant was reduced from $700 \mathrm{pg} / \mathrm{ml}$ to approximately $150 \mathrm{pg} / \mathrm{ml}$, whereas l-PEI only effectuated a reduction to $350 \mathrm{pg} / \mathrm{ml}$. The intracellular release was imaged by confocal microscopy and was shown to be significantly better for PAEI than for 1-PEI. Also the cell viability was conspicuously higher for PAEI at all measured concentrations. Similar results were obtained by the same group with a disulfide containing poly(amido amine) containing an aminohexyl sidegroup (p(CBA-DAH), Figure 2.5c) [52]. Model studies of polyplex degradation with DTT proved complete siRNA release within two hours and in PC-3 cells liberated siRNA was observed throughout the entire cells after I8 hours. This resulted in a significant higher VEGF knockdown as compared with cells treated with branched PEI polyplexes, 
Disulfide crosslinked PEI $\begin{gathered}\text { (SS-PEI) } \\ \text { a. }\end{gathered}$

b. (PAEI)

c.<smiles>CCCC(=O)NCCSSCCNC(=O)CC[N+](C)(C)C</smiles>
IN $\checkmark=0$

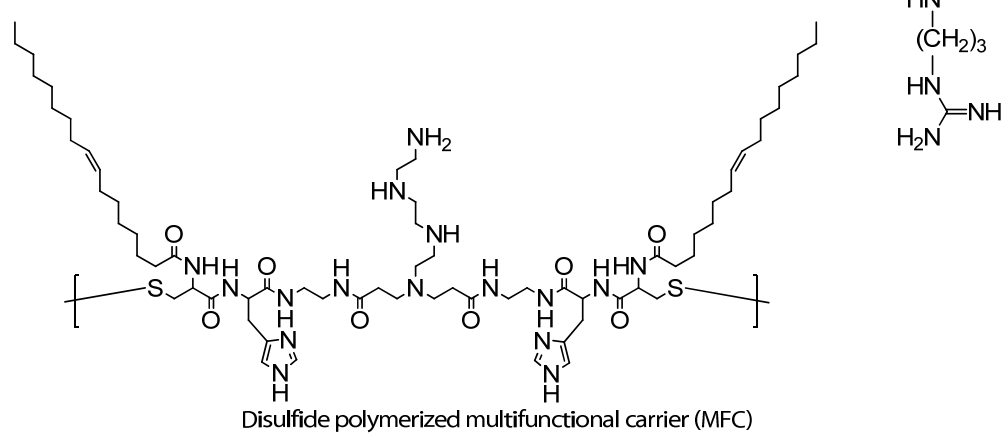<smiles>COCCOCC(C)CCC(C)(C)NC(CCCCN)C(C)(C)NC(C)C(C)=O</smiles>

Sulfhydryl functionalized PEG-PLL for disulfide crosslinked polyion complexes PIC

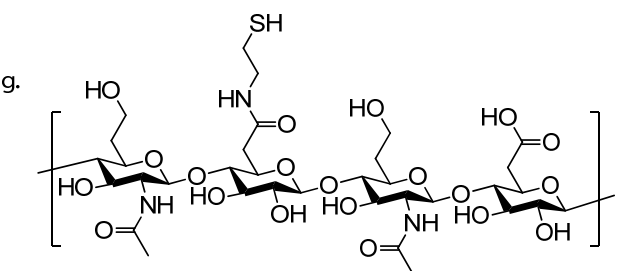

Sulfhydryl functionalized hyaluronic acid for disulfide crosslinked nanogels

Figure 2.5: Disulfide containing polymers to promote cytosolic degradation upon glutathione mediated disulfide reduction. 
without any cytotoxicity. The arginine functionalized polymer ( $\mathrm{p}(\mathrm{CBA}-\mathrm{DAH}-\mathrm{R})$, Figure 2.5d) was obtained by modification of the primary amine sidegroups of $\mathrm{p}(\mathrm{CBA}-\mathrm{DAH})$ and was used in a similar study [53]. Polyplex dissociation could be nicely visualized by confocal microscopy and knockdown of VEGF in PC-3, KB, HeLa, A278o and A549 cells showed similar efficiencies in all cells. Additionally, the toxicity profile of p(CBA-DAH$\mathrm{R}$ ) is excellent since it does not show any toxicity at a polymer/siRNA weight ratio up to 6o/r.

Wang et al. reported a polymer that was polymerized by disulfide formation, which they named 'multifunctional carrier' (MFC) (Figure 2.5e) [54]. Silencing was compared to DOTAP instead of PEI, due to the lipidic character of the MFC. Luciferase was knocked down to $40 \%$ of its original level against $60 \%$ for DOTAP. siRNA release from the carrier upon exposing the polyplexes to a reductive environment was unfortunately not reported, but in earlier work similar polyplexes with DNA proved to be reducible in the presence of DTT [55].

The group of Katoaka developed stable disulfide crosslinked polyion complexes (PIC) [I4]. PEG-PLL was treated with Traut's reagent to introduce sulfhydryl moieties on the primary amines of PLL with different degrees of thiolation (Figure 2.5f). The siRNA complexes were crosslinked using DMSO after complexation. The optimal thiolation degree to form stable particles turned out to be $14 \%$. Luciferase knockdown in presence of serum was Ioo times more efficient with these polyplexes than with their uncrosslinked analogues. The difference was attributed to the increased extracellular stability of the polyplexes created by the disulfide crosslinks.

Disulfides were also used in a hyaluronic acid / siRNA nanogel complex by Park et al. by the emulsification of a mixture of thiolated hyaluronic acid and siRNA, which were simultaneously crosslinked via oxidation of the free thiol groups (Figure 2.5g) [15]. The nanogels showed a quick release of siRNA after exposure to glutathione and showed a GFP silencing in HCT-II6 cells, that was comparable to polyplexes from b-PEl (40\% remaining GFP expression). The silencing efficiency was not affected by the presence of serum and the nanogels did not show any cytotoxicity.

Another possibility to enhance the release of siRNA by intracellular degradation of the polymer is by introducing acid-sensitive linkers in the polymer. The acid catalyzed hydrolysis of the linkers is induced by the acidification of the endosomal compartment during the endosomal maturation, which could lead to (partial) premature release of siRNA. This should not be a problem as long as the siRNAs do not end up in the lysosomes. Typical biocompatible pH-labile linker groups are acetals, ketals, orthoesters and hydrazones. They have been occasionally applied for gene delivery, though recently they have been investigated more frequently. Thus far, pH-labile linkers have been merely used for detaching PEG coatings, but recently the groups of Wagner and Kwon

30 - Chapter 2 
also used ketalized PEI to prepare polyplexes that destabilize in an acidic environment. Kwon et al. functionalized primary amines of LMW branched PEI $(800 \mathrm{~g} / \mathrm{mol})$ and HMW branched PEI $(25 \mathrm{~kg} / \mathrm{mol})$ at several degrees of ketal modification (Figure 2.6a). The ketalization was performed by activation with para-nitrophenyl chloroformate, followed by a substitution with diamine dimethylketal [56-57]. The rationale for this modification was twofold: the reduction in the amount of primary amines would mitigate the cytotoxicity of PEI and, moreover, would weaken the interaction of the polymer with siRNA, thereby facilitating the release of siRNA from the polyplex. Half lives at $\mathrm{pH} 5.0$ of hydrolytic degradation of the ketal linkers ranged between 2 and 5 hours, depending on the degree of ketalization, resulting in siRNA release after 90 minutes [58]. Gel electrophoresis experiments showed that LMW and HMW ketalized PEI were able to complex siRNA and release it upon hydrolysis up to N/P 40. TEM micrographs of swollen complexes after hydrolysis confirmed these observations. LMW ketalized PEI did not produce any silencing, since all of these complexes were localized mainly in the nucleus. HMW ketalized PEI on the other hand effectuated almost $80 \%$ knockdown of eGFP in NIH $3 \mathrm{~T}_{3}$ cells. A higher N/P ratio was needed for ketalized HMW PEI than for unmodified PEI to obtain similar results. On the other hand, the ketalized polymers did not show any toxicity, whereas PEI is extremely toxic above N/P 20. The degree of ketalization for optimal silencing appeared to be $23 \%$ of the primary amines.

The same group also investigated the effect of attaching primary amino groups via a ketal spacer to linear PEI (Figure 2.6b) [59]. LMW (2.5 kg/mol) and HMW PEI (25 $\mathrm{kg} / \mathrm{mol}$ ) were reacted with acrylamide-functionalized ketal linkers with a ketalization degree of 22 and $24 \mathrm{~mol} \%$, respectively. Hydrolysis of the ketal functions at $\mathrm{pH} 5.0$ proceeded with half lives around 2 hours. HMW ketalized PEI formed slightly larger polyplexes than non-modified PEl. Again, polyplex dissociation after hydrolysis was proven by gel electrophoresis and TEM. Confocal laser scanning micrographs revealed cytosolic dissociation of the ketalized polyplexes, whereas nonfunctionalized polyplexes were present in the nucleus. eGFP silencing efficiencies of $75 \%$ were obtained in $\mathrm{NIH}{ }_{3} \mathrm{~T}_{3}$ cells with ketalized LMW PEI in absence as well as in presence of serum with cell viabilities of $80 \%$. Comparison with polyplexes

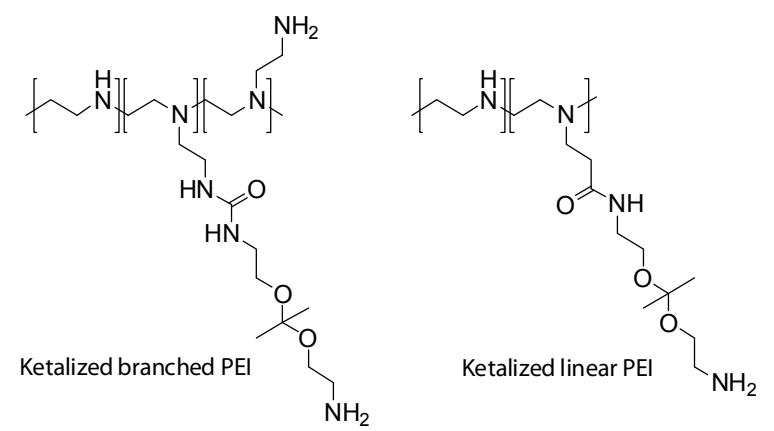

Figure 2.6: Acid labile dimethyl ketal grafted primary amines on branched (a) and linear PEI (b) to destabilize the siRNA complexes after endocytosis. 
using PEI with a non-degradable linker to the primary amine functions confirmed that the improved silencing properties were indeed caused by the acid labile ketal linker.

\subsection{In vivo delivery of siRNA}

For therapeutic application of siRNA, intracellular delivery is not the only challenge. For effective therapy without severe side effects, specific delivery of siRNA to the target site is necessary. Localized administration of siRNA avoids many of the difficulties associated with distribution of siRNA to non-target sites. However, many tissues can only be reached via the bloodstream, which requires systemic administration of the formulation.

\subsubsection{Local administration}

Several tissues are feasible for local administration of siRNA, including the eye, skin, muscles, lungs, brain and local tumors [6o-62]. Among the cationic polymers used in vivo, PEI (chemical structure in Figure I.2 of Chapter I) has been most widely applied. For example, an interesting application of PEI has been recently described by Merkel et al. [63]. In their study they showed, using actin-EGFP expressing mice, that intratracheal application of EGFP siRNA formulated in b-PEI $25 \mathrm{~kg} / \mathrm{mol}$ polyplexes leads to efficient EGFP silencing in the lung. The PEI polymers were first grafted with poly(ethylene glycol) (PEG), which increased protection and residing times in the lung of the PEG$\mathrm{PEI} / \mathrm{siRNA}$ complexes compared to PEI/siRNA complexes. In another example, b-PEI $(25 \mathrm{~kg} / \mathrm{mol}$ ) was conjugated to hyaluronic acid (HA) (Figure 2.7), an anionic biopolymer involved in wound healing, cell motility and angiogenesis [64]. The authors hypothesized that coating of the PEI/siRNA polyplexes with HA would enhance serum stability and facilitate cellular uptake via HA receptor-mediated endocytosis. In vitro, siRNA/PEI-HA complexes exhibited higher gene silencing efficiency than siRNA-PEI complexes, which was maintained in the presence of up to $50 \%$ serum. Furthermore, intratumoral injections of PEI-HA complexes containing anti-VEGF siRNA resulted in downregulation of VEGF in BI6FI tumors and effective inhibition of tumor growth. These systems could potentially be used for the treatment of diseases in tissues with HA receptors, such as liver cancer and kidney cancer [65].

The polysaccharide chitosan (chemical structure in Figure I.2 of Chapter I) is a good candidate for drug delivery because of its biodegradability, biocompatibility and low immunogenicity [66]. Chitosan-based systems have therefore also been investigated as siRNA delivery systems for different kinds of applications. Howard et al. introduced a chitosan-based siRNA nanoparticle delivery system for RNA interference in vitro and in

32 - Chapter 2 
vivo. Nasal administration of chitosan/siRNA particles resulted in approximately $40 \%$ silencing in bronchiole epithelial cells of transgenic EGFP mice, highlighting the potential application of these systems for treatment of mucosal diseases [67]. In a study by De Martimprey et al., chitosan was used for coating of nanoparticles [68]. They used a core-shell type of nanoparticles, where the core consisted of biodegradable poly(isobutylcyanoacrylate) polymer and the shell of positively charged chitosan (chemical structure after chitosan coupling does not become clear from the cited reference). Intratumoral injection of nanoparticles containing siRNA against the fusion oncogene ret/PTCI gave $82 \%$ silencing of the gene, resulting in significant inhibition of tumor growth. They also showed increased stability of nanoparticle-associated siRNA in tumors compared to free siRNA. Interestingly, because of their dual composition, these particles could additionally be loaded with hydrophobic compounds in the core, allowing for siRNA treatment in association with other anticancer molecules. Recently, chitosan nanoparticles were also used in cream for transdermal delivery of siRNA for the treatment of asthma [69].

Atellocollagen is a highly purified pepsin-treated type I collagen from calf dermis. It is low in immunogenicity and oligonucleotide-loaded polyplexes have shown nuclease resistance and increased cellular uptake [70]. It has been most widely used for intratumoral delivery of siRNA in preclinical settings to treat different kinds of cancer, including pancreatic cancer [71], HPVI6+ cervical cancer [72] and non-seminomatous germ cell cancer [73].

Long-term, local, sustained release of siRNA has been investigated using poly(DLlactic/glycolic acid) (PLGA) microspheres (Figure 2.7). In a study by Murata et al., antiVEGF siRNA, together with arginine or branched PEI as transfection agent, was encapsulated in PLGA microspheres and its release in phosphate buffer $(\mathrm{pH} 7.4)$ was shown to be sustained for over one month. Intratumoral injection of these systems obviously suppressed tumor growth for over three weeks [74].

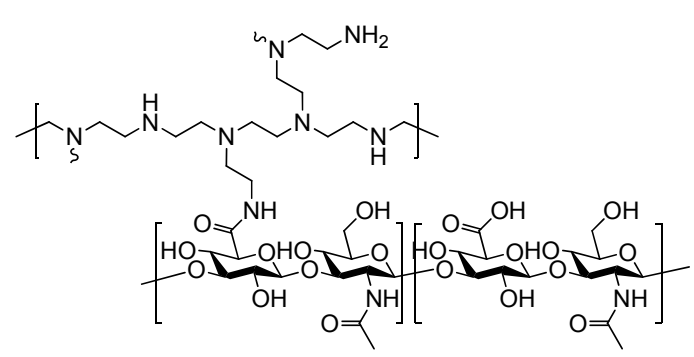

b-PEl coated hyaluronic acid

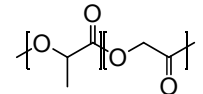

Poly(DL-lactic/glycolic acid) (PLGA)

Figure 2.7: Structural representation of the polymers used for local in vivo delivery of siRNA polyplexes. 


\subsubsection{Systemic administration}

Systemic administration of polyplexes is an attractive approach for delivery of siRNA to disseminated sites. While naked siRNA is fast degraded by serum nucleases in vivo, appropriate formulation of siRNA can prevent this and thereby increase its circulation time. Positively charged polyplexes, however, rapidly aggregate in the presence of salt or serum, which can lead to physical entrapment of the polyplexes within pulmonary capillary beds [75]. Furthermore, opsonization of polyplexes leads to rapid clearance by the reticuloendothelial systems (RES), resulting in uptake in RES-rich tissues such as the liver and spleen [76].

The biocompatibility of polyplexes can be enhanced by modification of their surface with non-ionic polymers like PEG. PEGylation of cationic polymers has been reported to reduce interaction with blood components and extend circulation times [77]. In a recent study, Merkel et al. traced pharmacokinetics and biodistribution of intravenously administered siRNA polyplexes formed with PEI $25 \mathrm{~kg} / \mathrm{mol}$ or PEGylated PEIs (b-PEI- $g$-PEG) (Figure 2.9a). They demonstrated that PEGylated polyplexes showed significantly less uptake in liver and spleen compared to PEI polyplexes [78]. In another study from the same group, the in vivo pharmacokinetics and tissue distribution of a broad panel of these PEI(-PEG)-based siRNA polyplexes after intravenous injection were investigated. They showed that the fate of the complexes mainly depended on the degree of uptake in liver, spleen, lung and kidney, and that the in vivo behavior of the polyplexes was determined by parameters such as siRNA complexation efficiency, complex stability in the presence of proteins, complex binding to plasma proteins and erythrocyte aggregation [79]. A new micelle-based delivery system for siRNA based on the formation of polyelectrolyte micelles between PEGylated siRNA and b-PEI (25 $\mathrm{kg} / \mathrm{mol}$ ) has been described by Kim et al. [8o]. The self-assembled, core-shell structures containing VEGF siRNA were used for anti-angiogenic therapy. Biodistribution experiments showed that 24 hours after intravenous (i.v.) injection, siRNA levels in PC-3 tumors were significantly higher for siRNA-PEG/PEI micelles than for siRNA/PEI formulations. For anti-angiogenic therapy, micelles were injected intravenously on days o, 4, Iо, I8 and 28 after tumors had reached $50 \mathrm{~mm}^{3}$, which gave efficient VEGF silencing, leading to decreased microvessel density in tumors and significantly lower tumor volumes.

The body distribution of siRNA polyplexes can also be changed using targeting agents. In their study on PEG-coated poly(propylene imine) dendrimer siRNA complexes (Figure 2.9b), Taratula et al. showed that tumor targeting by a Luteinizing Hormone-Releasing Hormone (LHRH) peptide conjugated to the distal end of the PEG polymer significantly altered the fate of the dendrimer and siRNA. After systemic injection, non-targeted dendrimer and delivered siRNA were found mainly in the liver and the kidney, while only trace amounts accumulated in the tumor. In contrast,

$34 \cdot$ Chapter 2 
targeted dendrimer and delivered siRNA were predominately found in the tumor [8I]. In a study from a different group, however, it was claimed that both non-targeted and targeted siRNA nanoparticles exhibit similar biodistribution and tumor localization [82].

Actively targeted polyplexes were also constructed by PEGylation of branched PEI polyplexes with a cyclic Arg-Gly-Asp (RGD) peptide ligand attached at the distal end of the PEG (Figure 2.9c). RGD peptides are recognized by integrins, expressed by tumor neovasculature. Polyplexes were prepared using siRNA against vascular endothelial growth factor receptor-2 (VEGFR-2) and their uptake was found to be dependent on the presence of the ligand. After intravenous administration, selective uptake in tumors, siRNA sequence-specific inhibition of VEGFR-2 as well as inhibition of angiogenesis and tumor growth rate were shown [83]. Tietze et al. used the serum protein transferrin (Tf) as both targeting and surface shielding agent for oligoethyleneimine (OEI) polyplexes. They showed that incorporation of $\mathrm{Tf}$ in the polyplexes prevented their aggregation and reduced their surface charge. Furthermore, systemic delivery of Tf-OEI polyplexes formulated with siRNA against RAN (three intravenous applications at a 3 days interval) resulted in $>80 \%$ silencing, apoptosis of neuro2A tumor cells and reduced tumor growth [84].

Passively targeting of tumor tissue is possible due to the so called EPR (enhanced permeation and retention) effect (Figure 2.8). This effect of passive accumulation in tumors after systemic administration has been described for many molecular agents and is caused by defective vasculature combined with impaired lymphatic drainage observed universally for solid tumors [85]. Yuan at al reported an average pore size in these leaky vessels of around $400 \mathrm{~nm}$, resulting in an enhanced permeability for macromolecules and nanoparticles of sizes below that cut-off value [86]. PEI-complexed siRNA has been successfully used to deliver intact siRNAs into subcutaneous tumor xenografts after intraperitoneal (i.p.) administration [87-88]. Using ${ }^{32}$ P-labeled siRNA, Urban-Klein et al. showed that, compared to other organs, particularly strong siRNA signals were observed in the tumors, 30 minutes and 4 hours after administration. The authors contributed the preferential uptake in tumors to high vascularization in the tumor and the EPR effect. Northern blotting revealed a

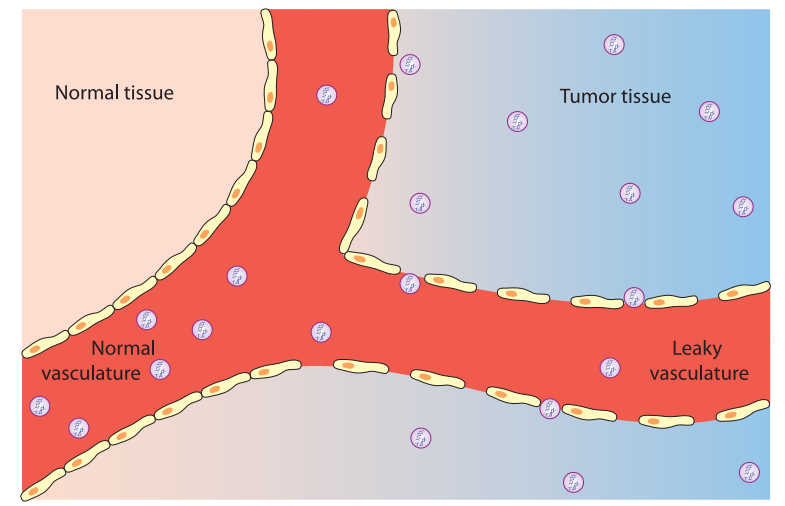

Figure 2.8: Passive tumor targeting by the enhanced permeation and retention (EPR) effect. 
$\sim 50 \%$ reduction of the target gene (HER-2) in the tumors, which resulted in a significant reduction of tumor growth. I.p. injection of naked HER-2 siRNA failed to show any inhibitory effect [88].

Dynamic PolyConjugates are interesting systems for the delivery of siRNA to hepatocytes [89]. In these systems, siRNA, shielding agent PEG and the hepatocyte targeting agent $\mathrm{N}$-acetylgalactosamine (NAG) are reversibly attached to a endosomolytic

a.

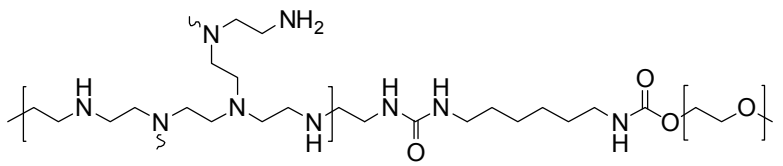

Branched poly(ethylene imine)-graft-poly(ethylene glycol) (b-PEI-g-PEG)

b.

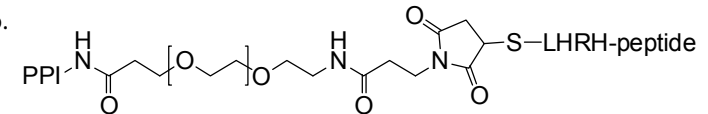

LHRH-PEG-coated poly(propylene imine) (PPI) dendrimer

c.

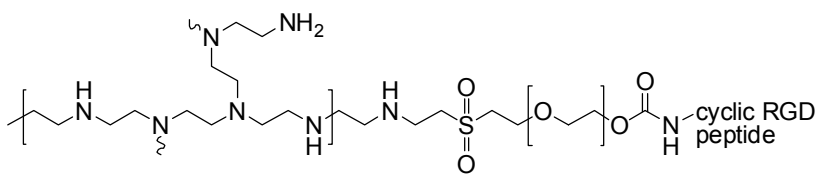

Branched poly(ethylene imine)-graft-poly(ethylene glycol) with a distal cyclic RGD

d.

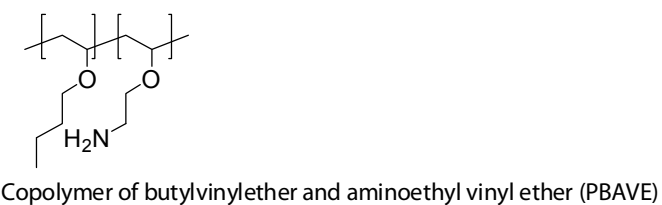

Figure 2.9: Structural representation of the polymers used for systemic in vivo delivery of siRNA polyplexes. polymer composed of butyl and amino vinyl ethers (PBAVE) (Figure 2.9d). In the low $\mathrm{pH}$ environment of the endosomes, the system disassembles, unmasking the polymer's amine groups and activating its endosomolytic properties. Using this technology, effective silencing of apolipoprotein B (apoB) in the liver was demonstrated after i.v. injection, which resulted in a significant reduction in serum cholesterol. It is anticipated that incorporation of other ligands into the system enables targeting to other tissues or cell types.

Very promising results have been obtained using cyclodextrin-containing polymers (CDP) [90] (Figure 2.IOa). These polymers are also polycationic and contain imidazole endgroups to assist in the intracellular trafficking [9r]. The polymers self-assemble with siRNA to form colloidal particles of about $50 \mathrm{~nm}$. For systemic delivery, Hu-Lieskovan et al. stabilized these particles using an PEG-adamantane conjugate (PEG-AD) (Figure 2.Iob), based on inclusion complex formation between adamantane and cyclodextrin (Figure 2.Ioc and d). Some of the PEG chains contained transferrin as a tumor-targeting ligand. Reduction of the EWS-FLII protein, involved in tumorigenesis of Ewing's family of tumors (EFT), was demonstrated after tail-vein injection of EWS-FLII siRNA loaded

$36 \cdot$ Chapter 2 
CDP nanoparticles on two consecutive days, while long-term delivery (twice weekly for 4 weeks) almost completely inhibited growth of metastasized EFT [92]. These systems may have a broad applicability in cancer therapy, targeting different genes and/or tumor types. For instance, administration of these particles carrying siRNA against ribonucleotide reductase subunit $\mathrm{M}_{2}$ (RRM2) also led to growth inhibition of subcutaneous Neuro2A tumors [93]. Similar nanoparticles are currently also being evaluated in the clinic for the treatment of cancer, as the first systemically delivered siRNA complexes (CALAA-or from Calando Pharmaceuticals).

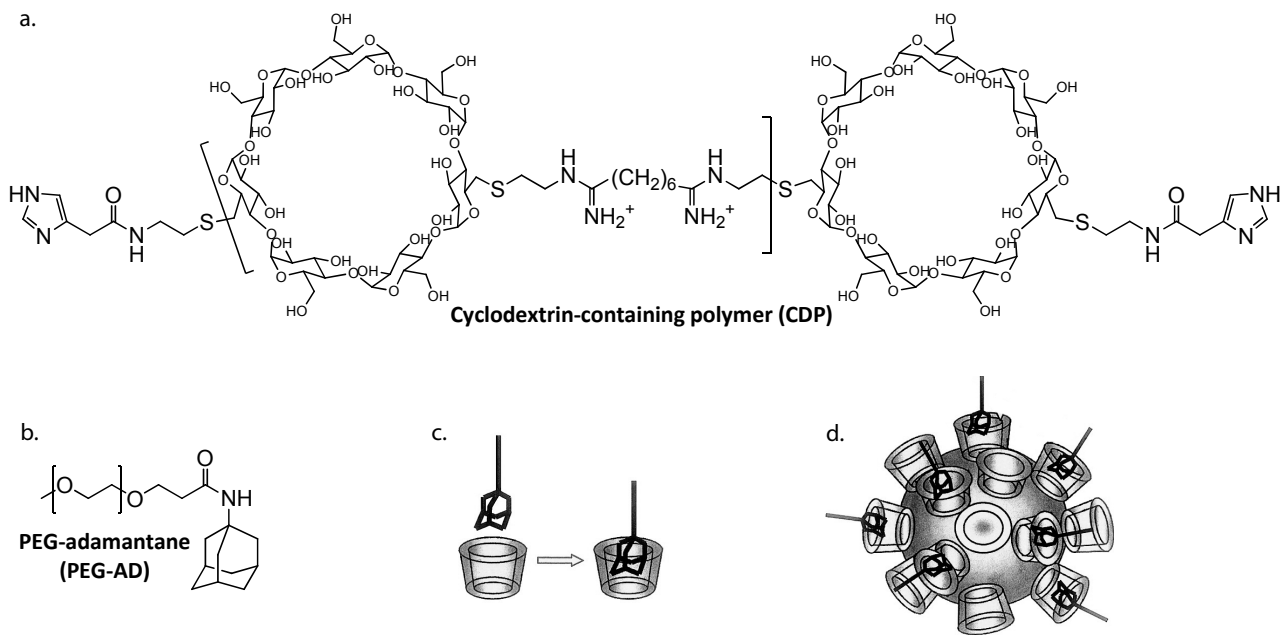

Figure 2.10: Schematic representations of the cyclodextrin-containing polymer (CDP) (a); adamantane functionalized PEG (PEG-AD) (b); the PEG-AD inclusion complex formation with cyclodextrin (blue cups) and the PEGylated CDP/siRNA complex [90].

\subsection{Safety issues}

Although polymers have the potential to be widely used in the clinic for the delivery of siRNA, their toxic effects are still an obstacle. These effects can be classified into acute and delayed effects and are dependent on characteristics such as molecular weight and degree of branching of the polymer and the size and zeta potential of the polyplexes. Acute effects result from the cationic nature of the polymer. For PEI, it has been shown that systemic administration leads to interaction of the cationic polymers with negatively charged serum proteins and red blood cells, causing precipitation in high clusters and adherence to cell surfaces [94]. These effects can be prevented by shielding of the charge using non-ionic polymers like PEG. More important and difficult to overcome are delayed effects that occur after polyplexes have left the 
circulation and are taken up by cells. After decomplexation, the polymers can interact with cellular components and interfere with normal cellular processes. Furthermore, they can cause several changes to cells, including cell shrinkage, reduced number of mitoses and vacuolization of the cytoplasm [95].

Despite these considerations, very promising results have been obtained in a study by Heidel et al., who were the first to test the safety of their polyplexes in non-human primates [96]. For their targeted CDP polyplexes (see previous section) they performed an extensive toxicity study in cynomolgus monkeys. After escalating intravenous doses of 3, 9 and $27 \mathrm{mg}$ siRNA/kg, blood samples were drawn for analyses of complete blood counts, serum chemistry, coagulation parameters, complement factors, antibodies, cytokines and pharmacokinetics. In general, the particles were well tolerated at doses of 3 and $9 \mathrm{mg}$ siRNA $/ \mathrm{kg}$. At $27 \mathrm{mg}$ siRNA $/ \mathrm{kg}$, an increase in blood urea nitrogen and creatinine was found, indicative of renal dysfunction. Furthermore, mild increases in aspartate transaminase and alanine amino transferase also suggest that there may have been some effect on the liver. Coagulation parameters were not affected, whereas modest evaluation in specific cytokines was observed, suggesting limited immunostimulation. Overall, no clinical signs of toxicity attributable to the treatments were observed. These data suggest that multiple, systemic doses of the nanoparticles can be safely administered to non-human primates.

Recent toxicogenomic studies have shown that polymers can also elicit wide ranging gene changes in cells [97]. Altered gene expression profiles for cells that had taken up polymers have already been shown for several polymers including PEI [97], PPI [98], PEG [99] and PAMAM-based dendrimers [Iоo]. These off-target effects can affect the safety of the formulation. Currently, biodegradable polymers are investigated with increased interest to overcome these kind of problems. In this thesis biodegradable disulfide containing poly(amido amine)s (SS-PAAs) are proposed and investigated as a non-toxic alternative in siRNA delivery.

\subsection{Conclusions}

RNAi has become one of the most promising approaches in the development of therapy for a wide range of diseases, but successes in (pre-) clinical studies are still limited due to inefficient delivery of siRNA to the target site. Polymer-based systems are promising delivery systems that can be chemically tailored for efficient siRNA protection and intracellular delivery. Although results of studies using polymers are increasingly encouraging, more insight into the mechanism of cellular delivery and pharmacokinetics of these systems will help to develop novel and better delivery systems. Moving towards clinical use, safety issues will become of higher importance,

38 - Chapter 2 
which will broaden the need for safe and biodegradable systems that are well characterized for their off-target effects.

\subsection{References}

I. Xiong, X.B., H. Uludag, and A. Lavasanifar, Biodegradable amphiphilic poly(ethylene oxide)-block-polyesters with grafted polyamines as supramolecular nanocarriers for efficient siRNA delivery. Biomaterials, 2009. 30(2): p. 242-253.

2. $\quad$ Gary, D.J., N. Puri, and Y.-Y. Won, Polymer-based siRNA delivery: Perspectives on the fundamental and phenomenological distinctions from polymer-based DNA delivery. Journal of Controlled Release, 2007. I2I(I-2): p. 64-73.

3. Spagnou, S., A.D. Miller, and M. Keller, Lipidic carriers of siRNA: Differences in the formulation, cellular uptake, and delivery with plasmid DNA. Biochemistry, 2004. 43(42): p. I3348-I3356.

4. Bolcato-Bellemin, A.L., et al., Sticky overhangs enhance siRNA-mediated gene silencing. Proceedings of the National Academy of Sciences of the United States of America, 2007. 104(4I): p. I6050-16055.

5. Rhinn, H., et al., How to make siRNA lipoplexes efficient? Add a DNA cargo. Biochimica Et Biophysica Acta-General Subjects, 2009. I79o(4): p. 219-230.

6. Li, S.D., et al., Tumor-targeted delivery of siRNA by self-assembled nanoparticles. Molecular Therapy, 2008. I6(I): p. I63-169.

7. DeRouchey, J., R.R. Netz, and J.O. Radler, Structural investigations of DNApolycation complexes. European Physical Journal E, 2005. I6(I): p. 17-28.

8. Mascotti, D.P. and T.M. Lohman, Thermodynamic Extent of Counterion Release Upon Binding Oligolysines to Single-Stranded Nucleic-Acids. Proceedings of the National Academy of Sciences of the United States of America, I990. 87(8): p. 3I42-3146.

9. $\quad$ Mateos-Timoneda, M.A., et al., Poly(amido amine)s as Gene Delivery Vectors: Effects of Quaternary Nicotinamide Moieties in the Side Chains.

ChemMedChem, 2007. 3: p. 478-486.

Io. Mascotti, D.P. and T.M. Lohman, Thermodynamics of oligoarginines binding to RNA and DNA. Biochemistry, 1997.36(23): p. 7272-7279.

II. Philipp, A., et al., Hydrophobically Modified Oligoethylenimines as Highly Efficient Transfection Agents for siRNA Delivery. Bioconjugate Chemistry, 2009. 20(II): p. 2055-206I.

I2. Oskuee, R.K., et al., The impact of carboxyalkylation of branched polyethylenimine on effectiveness in small interfering RNA delivery. Journal Of Gene Medicine, 2010. 12(9): p. 729-738.

I3. Varkouhi, A.K., et al., Gene Silencing Activity of siRNA Polyplexes Based on Thiolated N,N,N-Trimethylated Chitosan. Bioconjugate Chemistry, 2 oro. 2I(I2): p. 2339-2346. 
I4. Matsumoto, S., et al., Environment-Responsive Block Copolymer Micelles with a Disulfide Cross-Linked Core for Enhanced siRNA Delivery.

Biomacromolecules, 2009. Io(I): p. II9-I27.

I5. Lee, H., et al., Target-specific intracellular delivery of siRNA using degradable hyaluronic acid nanogels. Journal Of Controlled Release, 2007. II9(2): p. 245252.

I6. Fischer, D., et al., In vitro cytotoxicity testing of polycations: influence of polymer structure on cell viability and hemolysis. Biomaterials, 2003. 24(7): p. II2I-II3I.

I7. Grayson, A.C.R., A.M. Doody, and D. Putnam, Biophysical and structural characterization of polyethylenimine-mediated siRNA delivery in vitro. Pharmaceutical Research, 2006. 23(8): p. I868-I876.

I8. Mislick, K.A. and J.D. Baldeschwieler, Evidence for the role of proteoglycans in cation-mediated gene transfer. Proceedings of the National Academy of Sciences of the United States of America, I996. 93(22): p. I2349-I2354.

I9. Khalil, I.A., et al., Uptake pathways and subsequent intracellular trafficking in nonviral gene delivery. Pharmacological Reviews, 2006. 58(I): p. 32-45.

20. Wieffer, M., T. Maritzen, and V. Haucke, SnapShot: Endocytic Trafficking. Cell, 2009. $137(2)$ : p. 3.

2I. van der Aa, M., et al., Cellular uptake of cationic polymer-DNA complexes via caveolae plays a pivotal role in gene transfection in COS-7 cells. Pharmaceutical Research, 2007. 24(8): p. I590-I598.

22. Rejman, J., A. Bragonzi, and M. Conese, Role of clathrin-and caveolaemediated endocytosis in gene transfer mediated by lipo-and polyplexes.

Molecular Therapy, 2005. I2(3): p. 468-474.

23. Vercauteren, D., et al., Flotillin-dependent endocytosis and a phagocytosis-like mechanism for cellular internalization of disulfide-based poly(amido amine)/DNA polyplexes. Biomaterials, 20II. 32(II): p. 3072-3084.

24. Boussif, O., et al., $A$ Versatile Vector for Gene and Oligonucleotide Transfer into Cells in Culture and in-Vivo - Polyethylenimine. Proceedings of the National Academy of Sciences of the United States of America, I995. 92(I6): p. 7297-730I.

25. Behr, J.P., The proton sponge: A trick to enter cells the viruses did not exploit. Chimia, I997. 5I(I-2): p. 34-36.

26. Funhoff, A.M., et al., Endosomal escape of polymeric gene delivery complexes is not always enhanced by polymers buffering at low $\mathrm{pH}$. Biomacromolecules, 2004. 5(I): p. 32-39.

27. Godbey, W.T., et al., Poly(ethylenimine)-mediated transfection: A new paradigm for gene delivery. Journal of Biomedical Materials Research, 2000. 5I(3): p. 32I-328.

28. Sonawane, N.D., F.C. Szoka, and A.S. Verkman, Chloride accumulation and swelling in endosomes enhances DNA transfer by polyamine-DNA polyplexes. Journal of Biological Chemistry, 2003. 278(45): p. 44826-44831.

29. Cheng, J.J., et al., Structure - Function correlation of chloroquine and analogues as transgene expression enhancers in nonviral gene delivery. Journal of Medicinal Chemistry, 2006. 49(22): p. 6522-6531. 
30. Wattiaux, R., et al., Endosomes, lysosomes: their implication in gene transfer. Advanced Drug Delivery Reviews, 2000. 4I(2): p. 20I-208.

31. Hong, S.P., et al., Interaction of polycationic polymers with supported lipid bilayers and cells: Nanoscale hole formation and enhanced membrane permeability. Bioconjugate Chemistry, 2006. I7(3): p. 728-734.

32. Miyata, K., et al., Polyplexes from Poly(aspartamide) Bearing I,2Diaminoethane Side Chains Induce pH-Selective, Endosomal Membrane Destabilization with Amplified Transfection and Negligible Cytotoxicity. Journal of the American Chemical Society, 2008. 130(48): p. I6287-16294.

33. Kim, H.J., et al., Introduction of stearoyl moieties into a biocompatible cationic polyaspartamide derivative, $P A s p(D E T)$, with endosomal escaping function for enhanced siRNA-mediated gene knockdown. Journal Of Controlled Release, 2010. I45(2): p. I4I-I48.

34. Wang, X.L., R.Z. Xu, and Z.R. Lu, A peptide-targeted delivery system with $p H$ sensitive amphiphilic cell membrane disruption for efficient receptor-mediated SiRNA delivery. Journal of Controlled Release, 2009. 134(3): p. 207-213.

35. Fischer, W., et al., Dendritic Polyglycerols with Oligoamine Shells Show Low Toxicity and High siRNA Transfection Efficiency in Vitro. Bioconjugate Chemistry, 20IO. 2I(IO): p. I744-I752.

36. Kwon, E.J., J.M. Bergen, and S.H. Pun, Application of an HIV gp4I-derived peptide for enhanced intracellular trafficking of synthetic gene and siRNA delivery vehicles. Bioconjugate Chemistry, 2008. 19(4): p. 920-927.

37. Meyer, M., et al., Breathing life into polycations: Functionalization with $\mathrm{pH}$ responsive endosomolytic peptides and polyethylene glycol enables siRNA delivery. Journal of the American Chemical Society, 2008. I30(II): p. 3272-+.

38. Meyer, M., et al., Synthesis and Biological Evaluation of a Bioresponsive and Endosomolytic siRNA-Polymer Conjugate. Molecular Pharmaceutics, 2009. 6(3): p. $752-762$.

39. Okuda, T., T. Niidome, and H. Aoyagi, Cytosolic soluble proteins induce DNA release from DNA-gene carrier complexes. Journal of Controlled Release, 2004. 98(2): p. 325-332.

40. Huth, S., et al., Interaction of polyamine gene vectors with RNA leads to the dissociation of plasmid DNA-carrier complexes. Journal of Gene Medicine, 2006. 8(I2): p. I4I6-I424.

4I. Wu, G.Y., et al., Glutathione metabolism and its implications for health. Journal of Nutrition, 2004. 134(3): p. 489-492.

42. Manickam, D.S. and D. Oupicky, Polyplex gene delivery modulated by redox potential gradients. Journal Of Drug Targeting, 2006. I4(8): p. 519-526.

43. Breunig, M., et al., Breaking up the correlation between efficacy and toxicity for nonviral gene delivery. Proceedings of the National Academy of Sciences of the United States of America, 2007. I04(36): p. I4454-I4459.

44. Lin, C., et al., Novel Bioreducible Poly(amido amine)s for Highly Efficient Gene Delivery. Bioconjugate Chemistry, 2007. I8(I): p. I38-I45.

45. Miguel A. Mateos-Timoneda, Martin C.L.Wim E.H.J.F.Johan F.J.E., Poly(amido amine)s as Gene Delivery Vectors: Effects of Quaternary Nicotinamide Moieties in the Side Chains, in ChemMedChem. 2007. p. 478-486. 
46. Piest, M., et al., Novel poly(amido amine)s with bioreducible disulfide linkages in their diamino-units: Structure effects and in vitro gene transfer properties. Journal of Controlled Release, 2008. 130(I): p. 38-45.

47. Lin, C., et al., Linear poly(amido amine)s with secondary and tertiary amino groups and variable amounts of disulfide linkages: Synthesis and in vitro gene transfer properties. Journal of Controlled Release, 2006. II6(2): p. I30-I37.

48. Chen, J., C. Wu, and D. Oupicky, Bioreducible Hyperbranched Poly(amido amine)s for Gene Delivery. Biomacromolecules, 2009. Io(Io): p. $292 \mathrm{I}-2927$.

49. Manickam, D.S., et al., Effect of innate glutathione levels on activity of redoxresponsive gene delivery vectors. Journal Of Controlled Release, 20IO. I4I(I): $\mathrm{p}$. 77-84.

50. Breunig, M., et al., Mechanistic investigation of poly(ethylene imine)-based siRNA delivery: Disulfide bonds boost intracellular release of the cargo. Journal of Controlled Release, 2008. 130(I): p. 57-63.

5I. Hoon Jeong, J., et al., Reducible poly(amido ethylenimine) directed to enhance RNA interference. Biomaterials, 2007. 28(I0): p. I912-1917.

52. Kim, S.H., et al., Reductive Degradation Behavior of Bioreducible Poly(disulfide amine) for Enhancing SiRNA Efficiency. Macromolecular Bioscience, 2010. Io(8): p. 898-905.

53. Kim, S.H., et al., VEGF siRNA Delivery System Using Arginine-Grafted Bioreducible Poly(disulfide amine). Molecular Pharmaceutics, 2009. 6(3): p. 718-726.

54. Wang, X.-L., et al., A multifunctional and reversibly polymerizable carrier for efficient siRNA delivery. Biomaterials, 2008. 29(I): p. 15-22.

55. Wang, X.L., R. Jensen, and Z.R. Lu, A novel environment-sensitive biodegradable polydisulfide with protonatable pendants for nucleic acid delivery. Journal of Controlled Release, 2007. 120(3): p. 250-258.

56. Shim, M.S. and Y.J. Kwon, Controlled cytoplasmic and nuclear localization of plasmid DNA and siRNA by differentially tailored polyethylenimine. Journal of Controlled Release, 2009. 133(3): p. 206-213.

57. Shim, M.S. and Y.J. Kwon, Controlled delivery of plasmid DNA and siRNA to intracellular targets using ketalized polyethylenimine. Biomacromolecules, 2008. 9(2): p. 444-455.

58. Shim, M.S., et al., Dynamics of Nucleic Acid/Cationic Polymer Complexation and Disassembly Under Biologically Simulated Conditions Using In Situ Atomic Force Microscopy. Microscopy Research and Technique, 2010. 73(9): p. $845-856$.

59. Shim, M.S. and Y.J. Kwon, Acid-Responsive Linear Polyethylenimine for Efficient, Specific, and Biocompatible siRNA Delivery. Bioconjugate Chemistry, 2009. 20(3): p. 488-499.

6o. $\quad$ Oliveira, S., et al., Delivery of siRNA to the target cell cytoplasm: photochemical internalization facilitates endosomal escape and improves silencing efficiency, in vitro and in vivo. Curr Pharm Des, 2008. I4(34): p. 368697.

61. Bitko, V., et al., Inhibition of respiratory viruses by nasally administered siRNA. Nat Med, 2005. II(I): p. 50-5.

42. Chapter 2 
62. Kim, B., et al., Inhibition of ocular angiogenesis by siRNA targeting vascular endothelial growth factor pathway genes: therapeutic strategy for herpetic stromal keratitis. Am J Pathol, 2004. 165(6): p. 2177-85.

63. Merkel, O.M., et al., Nonviral siRNA delivery to the lung: investigation of PEGPEI polyplexes and their in vivo performance. Mol Pharm, 2009. 6(4): p. I24660.

64. Price, R.D., et al., The role of hyaluronic acid in wound healing: assessment of clinical evidence. Am J Clin Dermatol, 2005. 6(6): p. 393-402.

65. Jiang, G., et al., Target specific intracellular delivery of siRNA/PEI-HA complex by receptor mediated endocytosis. Mol Pharm, 2009. 6(3): p. 727-37.

66. Prabaharan, M. and J.F. Mano, Chitosan-based particles as controlled drug delivery systems. Drug Deliv, 2005. 12(I): p. 4I-57.

67. Howard, K.A., et al., RNA interference in vitro and in vivo using a novel chitosan/siRNA nanoparticle system. Mol Ther, 2006. I4(4): p. 476-84.

68. de Martimprey, H., et al., siRNA nanoformulation against the ret/PTCI junction oncogene is efficient in an in vivo model of papillary thyroid carcinoma. Nucleic Acids Res, 2008. 36(I): p. e2.

69. Wang, X., et al., Prevention of airway inflammation with topical cream containing imiquimod and small interfering $R N A$ for natriuretic peptide receptor. Genet Vaccines Ther, 2008. 6: p. 7.

70. Ochiya, T., et al., Biomaterials for gene delivery: atelocollagen-mediated controlled release of molecular medicines. Curr Gene Ther, 200I. I(I): p. 3I-52.

7I. Iwaki, K., et al., $A$ small interfering $R N A$ targeting proteinase-activated receptor-2 is effective in suppression of tumor growth in a PancI xenograft model. Int J Cancer, 2008. I22(3): p. 658-63.

72. Yamato, K., et al., New highly potent and specific E6 and E7 siRNAs for treatment of HPVI6 positive cervical cancer. Cancer Gene Ther, 2008. 15(3): p. I40-53.

73. Minakuchi, Y., et al., Atelocollagen-mediated synthetic small interfering RNA delivery for effective gene silencing in vitro and in vivo. Nucleic Acids Res, 2004. 32(I3): p. eIo9.

74. Murata, N., et al., Anti-tumor effects of anti-VEGF siRNA encapsulated with PLGA microspheres in mice. J Control Release, 2008. 126(3): p. 246-54.

75. Howard, K.A., Delivery of RNA interference therapeutics using polycationbased nanoparticles. Adv Drug Deliv Rev, 2009. 6I(9): p. 710-20.

76. Owens, D.E., 3rd and N.A. Peppas, Opsonization, biodistribution, and pharmacokinetics of polymeric nanoparticles. Int J Pharm, 2006. 307(I): p. 93IO2.

77. $\quad$ Ogris, M., et al., PEGylated DNA/transferrin-PEI complexes: reduced interaction with blood components, extended circulation in blood and potential for systemic gene delivery. Gene Ther, 1999. 6(4): p. 595-605.

78. Merkel, O.M., et al., Stability of siRNA polyplexes from poly(ethylenimine) and poly(ethylenimine)-g-poly(ethylene glycol) under in vivo conditions: effects on pharmacokinetics and biodistribution measured by Fluorescence Fluctuation Spectroscopy and Single Photon Emission Computed Tomography (SPECT) imaging. J Control Release, 2009. I38(2): p. I48-59. 
79. Malek, A., et al., In vivo pharmacokinetics, tissue distribution and underlying mechanisms of various PEI(-PEG)/siRNA complexes. Toxicol Appl Pharmacol, 2009. 236(I): p. 97-I08.

8o. Kim, S.H., et al., Local and systemic delivery of VEGF siRNA using polyelectrolyte complex micelles for effective treatment of cancer. J Control Release, 2008. 129(2): p. I07-I6.

8I. Taratula, O., et al., Surface-engineered targeted PPI dendrimer for efficient intracellular and intratumoral siRNA delivery. J Control Release, 2009. I40(3): p. 284-93.

82. Bartlett, D.W., et al., Impact of tumor-specific targeting on the biodistribution and efficacy of siRNA nanoparticles measured by multimodality in vivo imaging. Proc Natl Acad Sci U S A, 2007. 104(39): p. 15549-54.

83. Schiffelers, R.M., et al., Cancer siRNA therapy by tumor selective delivery with ligand-targeted sterically stabilized nanoparticle. Nucleic Acids Res, 2004. 32(I9): p. eI49.

84. Tietze, N., et al., Induction of apoptosis in murine neuroblastoma by systemic delivery of transferrin-shielded siRNA polyplexes for downregulation of Ran. Oligonucleotides, 2008. 18(2): p. 161-74.

85. Maeda, H., et al., Tumor vascular permeability and the EPR effect in macromolecular therapeutics: a review. J Control Release, 2000. 65(I-2): p. 27I84 .

86. Yuan, F., et al., Vascular permeability in a human tumor xenograft: molecular size dependence and cutoff size. Cancer Research, I995. 55(I7): p. 3752-3756.

87. Grzelinski, M., et al., RNA interference-mediated gene silencing of pleiotrophin through polyethylenimine-complexed small interfering RNAs in vivo exerts antitumoral effects in glioblastoma xenografts. Hum Gene Ther, 2006. I7(7): p. 75I-66.

88. Urban-Klein, B., et al., RNAi-mediated gene-targeting through systemic application of polyethylenimine (PEI)-complexed siRNA in vivo. Gene Ther, 2005. I2(5): p. 46I-6.

89. Rozema, D.B., et al., Dynamic PolyConjugates for targeted in vivo delivery of siRNA to hepatocytes. Proc Natl Acad Sci U S A, 2007. I04(32): p. I2982-7.

90. Davis, M.E., The first targeted delivery of siRNA in humans via a selfassembling, cyclodextrin polymer-based nanoparticle: from concept to clinic. Mol Pharm, 2009. 6(3): p. 659-68.

9I. Davis, M.E., et al., Self-assembling nucleic acid delivery vehicles via linear, water-soluble, cyclodextrin-containing polymers. Curr Med Chem, 2004. II(2): p. I79-97.

92. Hu-Lieskovan, S., et al., Sequence-specific knockdown of EWS-FLII by targeted, nonviral delivery of small interfering RNA inhibits tumor growth in a murine model of metastatic Ewing's sarcoma. Cancer Res, 2005. 65(I9): p. 898492.

93. Bartlett, D.W. and M.E. Davis, Impact of tumor-specific targeting and dosing schedule on tumor growth inhibition after intravenous administration of siRNA-containing nanoparticles. Biotechnol Bioeng, 2008. 99(4): p. 975-85.

44 - Chapter 2 
94. Fischer, D., et al., A novel non-viral vector for DNA delivery based on low molecular weight, branched polyethylenimine: effect of molecular weight on transfection efficiency and cytotoxicity. Pharm Res, I999. I6(8): p. I273-9.

95. Lv, H., et al., Toxicity of cationic lipids and cationic polymers in gene delivery. J Control Release, 2006. II4(I): p. I00-9.

96. Heidel, J.D., et al., Administration in non-human primates of escalating intravenous doses of targeted nanoparticles containing ribonucleotide reductase subunit M2 siRNA. Proc Natl Acad Sci U S A, 2007. 104(I4): p. 57I5-2I.

97. Akhtar, S. and I. Benter, Toxicogenomics of non-viral drug delivery systems for RNAi: potential impact on siRNA-mediated gene silencing activity and specificity. Adv Drug Deliv Rev, 2007.59(2-3): p. I64-82.

98. Omidi, Y., et al., Polypropylenimine dendrimer-induced gene expression changes: the effect of complexation with DNA, dendrimer generation and cell type. J Drug Target, 2005. 13(7): p. 43I-43.

99. Kabanov, A.V., et al., Polymer genomics: shifting the gene and drug delivery paradigms. J Control Release, 2005. I0I(I-3): p. 259-7I.

Ioo. Hollins, A.J., et al., Toxicogenomics of drug delivery systems: Exploiting delivery system-induced changes in target gene expression to enhance siRNA activity. J Drug Target, 2007. I5(I): p. 83-8. 
46 - Chapter 2 


\title{
Chapter
}

\section{Optimization of poly(amido amine)s as vectors for siRNA delivery}

\author{
L.J. van $\operatorname{der} A a$ \\ P. Vader \\ R.M. Schiffelers \\ G. Storm \\ J.F.J. Engbersen
}




\begin{abstract}
By Michael addition polymerization of $N, N^{\prime}$-cystaminebisacrylamide (CBA) with variable ratios of 4-amino-I-butanol (ABOL) and ethylene diamine (EDA) or triethylenetetramine (TETA), poly(amido amine) copolymers could be obtained with tunable charge densities. The copolymers were optimized to serve as non-viral vectors in RNA interference (RNAi) to form stable, nanosized polyplexes with siRNA with maximum transfection efficacy. It was observed that at least $20-30 \%$ EDA or TETA amino units in the copolymers is necessary to encapsulate siRNA into small and stable polyplexes $(<200 \mathrm{~nm})$. Incorporation of higher amounts of EDA or TETA in the copolymers did not further improve polyplex formation and stability, but the increased cationic charge density in these copolymers resulted in increased cytotoxicity and hemolytic activity of the polymer. Copolymers with $20 \%$ EDA showed excellent gene silencing properties in vitro (70\% luciferase knockdown in Hi299 cells) with negligible cytotoxicity.
\end{abstract}

\title{
3.1 Introduction
}

Gene therapy has developed in the past decades to a promising strategy that has the potential to cure an innumerable range of diseases. The discovery of small interfering RNA (siRNA) even further boosted the research in this field, since for gene silencing a nuclear entry is not required to be effective. Numerous cationic polymers like poly(Llysine) (PLL), poly(ethylene imine) (PEI) [I-2], poly(2-(dimethylamino)ethyl methacrylate) (pDMAEMA) [3], chitosan [4], poly(amido amine) (PAA) [5-6] and PAA dendrimers [7] have been intensively investigated for the delivery of DNA during the past decade.

Recently, our group has developed several disulfide-containing poly(amido amine)s (SS-PAAs) that showed very promising properties as polymeric transfection reagents [8I2]. The disulfide linkages in these polymers are stable under physiological conditions, but enable a fast degradation in the reductive environment in the cytosol [9, I3]. Synthesis of these SS-PAAs easily allows for variations in the design to suit for the appropriate application. Previous studies have been primarily focused on the optimization of plasmid DNA transfection and it turned out that the SS-PAA composed of $N, N$-cystaminebisacrylamide (CBA) units and 4-amino-I-butanol (ABOL) showed excellent transfection properties in in vitro experiments in different cell lines [5, 9].

However, as described in Chapter 2, there are some fundamental differences between the long DNA and the short siRNA molecules, which means that existing DNA transfection systems usually cannot be simply transferred one to one for use in siRNA delivery. In this study we developed an SS-PAA specialized for siRNA delivery. The

48 - Chapter 3 
polymers are based on CBA and ABOL, copolymerized with ethylene diamine (EDA) or triethylenetetramine (TETA). In previous studies for pDNA transfection, copolymers of CBA and $\mathrm{ABOL}$ turned out to be efficient and non-toxic vectors. The CBA unit in the polymer introduces reducible disulfide linkages in the backbone; the butanolic side chain of ABOL gives the polymers the proper hydrophobicity / hydrophilicity balance, which apparently optimizes the transfection although the exact mechanism is still not clarified [ro]. To make these polymers suitable for siRNA delivery, we considered that an increased interaction between the polymers and the nucleotides would be necessary. Therefore, the amine density in the polymer backbone was increased by copolymerizing EDA or TETA in different ratios, to increase the electrostatic interactions. The amine containing moiety has a PEI like structure and since PEI (and polymers with high cationic charge in general) are known to be toxic [14], the amine density was tuned for optimal transfection efficiency with minimal toxicity. Additionally, since gene silencing can also be activated by siRNA that is produced inside the cell after transfection with an encoding plasmid DNA, the potential of the polymeric vectors for gene expression with pDNA were also investigated in this chapter.

\subsection{Materials and methods}

\subsubsection{Materials}

All chemicals and reference materials, 4-amino-I-butanol (ABOL, Aldrich), ethylene diamine (EDA, Merck), triethylenetetramine (TETA, Aldrich), $N, N$ ' cystaminebisacrylamide (CBA, Polysciences), sodium 3'-[I-phenylamino-carbonyl]-3,4tetrazolium]-bis[4-methoxy-6-nitro]benzenesulfonic acid hydrate (XTT, Polysciences), phenazine methosulfate (PMS, Aldrich), branched poly(ethylene imine) $(25 \mathrm{~kg} / \mathrm{mol}$, Aldrich), linear poly(ethylene imine) (Exgen 500, $22 \mathrm{~kg} / \mathrm{mol}$, Fermentas) and Lipofectamine 2000 (Invitrogen) were purchased in the highest purity and used without further purification. For culturing the H1299 Fluct cells RPMI I640 medium (Lonza) completed with $2 \%(\mathrm{v} / \mathrm{v})$ PennStrepp (Lonza), I\% (v/v) glutamine (Lonza) and Io\% (v/v) fetal bovine serum (Lonza) was used, COS-7 cells were cultured in DMEM containing $4,5 \mathrm{~g} / \mathrm{l}$ glucose (Invitrogen) completed with 2\% (v/v) PennStrepp (Lonza), I\% (v/v) glutamine (Lonza) and Io\% (v/v) fetal bovine serum (Lonza). Negative control siRNA was purchased from Qiagen, anti-luciferase siRNA was kindly supplied by the University of Utrecht and the plasmid pCMV-GFP was purchased from Plasmid Factory (Bielefeld, Germany). Luciferase assay reagent was obtained from Promega. 


\subsubsection{Synthesis of $p(C B A-A B O L / E D A)$ copolymers}

Copolymers with different degrees of 4-amino-I-butanol (ABOL) and ethylene diamine (EDA) were synthesized by a Michael addition polymerization (Scheme 3.I). To prevent branching as much as possible, $N, N$ '-cystaminebisacrylamide (CBA) and $\mathrm{ABOL}$ were first prepolymerized. In a typical example $700 \mathrm{mg}(2.69 \mathrm{mmol}) \mathrm{CBA}$ and $\mathrm{I} 8 \mathrm{o} \mathrm{mg}$ ( $2.02 \mathrm{mmol}) \mathrm{ABOL}$ were dissolved in methanol / water $(4 / \mathrm{I} \mathrm{v} / \mathrm{v})$ and were allowed to react at $45^{\circ} \mathrm{C}$ in the dark in a nitrogen atmosphere (I). The reaction mixture became homogeneous within one hour. Double bond consumption was monitored by ${ }^{\mathrm{I}} \mathrm{H}$ NMR (methanol- $\mathrm{d}_{4}$ ) and after six days no significant consumption was observed anymore (data not shown). After six days of prepolymerization, $40.5 \mathrm{mg}$ (0.67 mmol) EDA was added and the reaction was proceeded for another two days. Then the polymerization was terminated by addition of a 10\% molar excess EDA, to consume remaining toxic acrylamide endgroups. After termination, the reaction mixture was diluted with hydrochloric acid (IM) and water, purified by ultrafiltration (MWCO гоoо, pH5), filtered through a $0.45 \mu \mathrm{m}$ syringe filter and recovered as its $\mathrm{HCl}$ salt by lyophilization. ${ }^{\mathrm{I}} \mathrm{H}$ NMR $\left(\mathrm{D}_{2} \mathrm{O}\right) \delta(\mathrm{ppm})=\mathrm{I} .58\left(\mathrm{~m}, 2 \mathrm{H}, \boldsymbol{C H}_{2} \mathrm{CH}_{2} \mathrm{NR}\right) ; \mathrm{I} .78\left(\mathrm{~m}, 2 \mathrm{H}, \boldsymbol{C H}_{2} \mathrm{CH}_{2} \mathrm{OH}\right) ; 2.69(\mathrm{t}$, $\left.4 \mathrm{H}, \mathrm{NHCH} \mathrm{CH}_{2} \mathrm{NH}\right) ; 2.76\left(\mathrm{t}, 2 \mathrm{H}, \mathrm{CH}_{2} \mathrm{CONH}\right) ; 2.82\left(\mathrm{t}, 4 \mathrm{H}, \mathrm{CH}_{2} \mathrm{SSCH} \mathrm{CH}_{2}\right) ; 3.2 \mathrm{I}(\mathrm{t}, 2 \mathrm{H}$, $\left.\mathrm{CH}_{2} \mathrm{CH}_{2} \mathrm{NR}\right) ; 3.32$ (t, $\left.2 \mathrm{H}, \mathrm{COCH}_{2} \mathrm{CH}_{2} \mathrm{NH}\right) ; 3.44\left(\mathrm{t}, 4 \mathrm{H}, \mathrm{CH}_{2} \mathrm{NRCH}\right.$ ); $3.5 \mathrm{I}(\mathrm{t}, 4 \mathrm{H}$, $\left.\mathrm{NH} \mathrm{CH}_{2} \mathrm{CH}_{2} \mathrm{SSCH}_{2} \mathrm{CH}_{2} \mathrm{NH}\right) ; 3.6 \mathrm{I}\left(\mathrm{t}, 2 \mathrm{H}, \mathrm{CH}_{2} \mathrm{OH}\right.$ ).
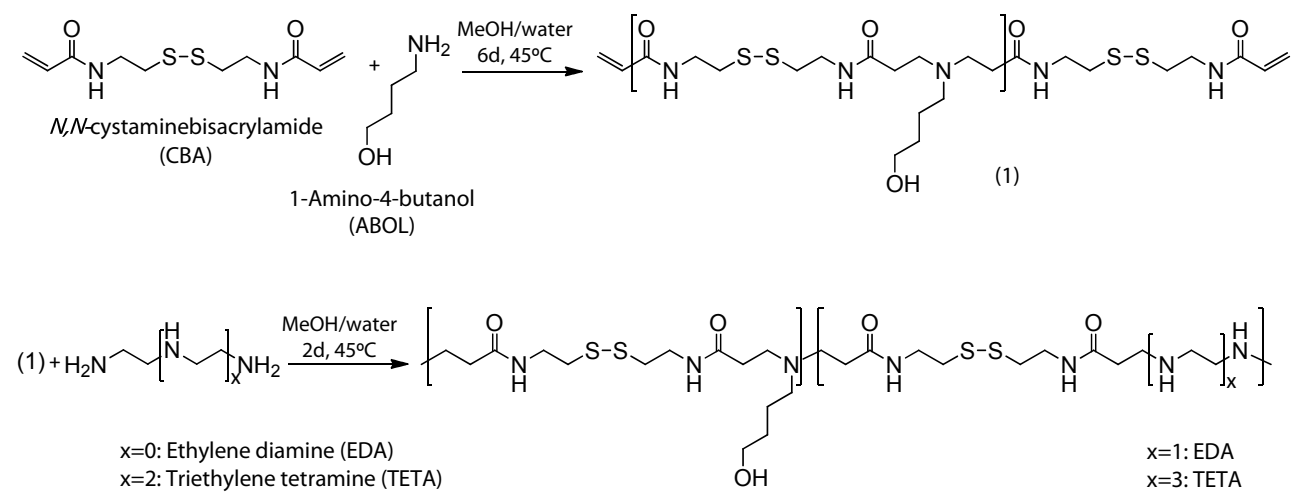

Scheme 3.1: Synthesis of the $p(C B A-A B O L / E D A)$ and $p(C B A-A B O L / T E T A)$ copolymers.

\subsubsection{Synthesis of $p(C B A-A B O L / T E T A)$ copolymers}

Copolymers with triethylenetetramine (TETA) moieties in the backbone were synthesized similarly as their EDA analogs with the only difference being that the reaction with TETA proceeded for $\mathrm{I} 6$ hours instead of two days. ${ }^{\mathrm{I}} \mathrm{H}$ NMR $\left(\mathrm{D}_{2} \mathrm{O}\right) \delta(\mathrm{ppm})$

50 - Chapter 3 
$=\mathrm{I} .58\left(\mathrm{~m}, 2 \mathrm{H}, \boldsymbol{C H}_{2} \mathrm{CH}_{2} \mathrm{NR}\right) ; \mathrm{I} .78\left(\mathrm{~m}, 2 \mathrm{H}, \boldsymbol{C H}_{2} \mathrm{CH}_{2} \mathrm{OH}\right) ; 2.73\left(\mathrm{t}, \mathrm{I} 2 \mathrm{H}, \mathrm{NH} \boldsymbol{C H}_{2} \mathrm{CH}_{2} \mathrm{NH}\right) ;$ 2.76 (t, $\left.2 \mathrm{H}, \mathrm{CH}_{2} \mathrm{CONH}\right) ; 2.82$ (t, $4 \mathrm{H}, \mathrm{CH}_{2} \mathrm{SSCH}$ ); $3.2 \mathrm{I}$ (t, $\left.2 \mathrm{H}, \mathrm{CH}_{2} \mathrm{CH}_{2} \mathrm{NR}\right) ; 3.32(\mathrm{t}, 2 \mathrm{H}$, $\mathrm{COCH}_{2} \mathrm{CH}_{2} \mathrm{NH}$ ); 3.44 (t, $4 \mathrm{H}, \mathrm{CH}_{2} \mathrm{NRCH}$ ); $3.5 \mathrm{I}\left(\mathrm{t}, 4 \mathrm{H}, \mathrm{NHCH} \mathrm{CH}_{2} \mathrm{SSCH}_{2} \mathrm{CH}_{2} \mathrm{NH}\right.$ ); $3.6 \mathrm{I}$ (t, $\left.2 \mathrm{H}, \mathrm{CH}_{2} \mathrm{OH}\right)$

\subsubsection{Polymer characterization}

Polymers were characterized by ${ }^{\mathrm{H}} \mathrm{H}$ NMR $\left(\mathrm{D}_{2} \mathrm{O}\right)$, recorded on a Varian Innova spectrometer $(300 \mathrm{MHz})$. Molecular weights were determined by GPC relative to PEG standards, using a GPCmax with an acetate buffer $\mathrm{pH} 4.5$ containing $30 \%(\mathrm{v} / \mathrm{v})$ methanol as eluent.

\subsubsection{Degree of branching}

The degree of branching (DB) was determined by analyzing the fragments of a degraded polymer using mass spectrometry, according to a slightly modified literature procedure [I5]. All polymers were dissolved at $2 \mathrm{mg} / \mathrm{ml}$ in a $20 \mathrm{mM}$ phosphate buffer $\mathrm{pH}$ 7.2 containing $15 \mathrm{mM}$ tris(2-carboxyethyl)phosphine hydrochloride (TCEP.HCl) and stirred for two hours at room temperature to reduce the disulfides. To prevent reoxidation of the obtained polymer fragments, the generated thiols were reacted with 2 equivalents of $N$-ethylmaleimide (NEM). After two hours of reaction, the samples were diluted roo times in an acetonitrile / water I/I (v/v) mixture containing $0 . \mathrm{I} \%$ formic acid and analyzed on Waters LCT instrument.

Finally the degree of branching is defined by $D B=\frac{B}{L+B+T}$ with $\mathrm{L}, \mathrm{B}$ and $\mathrm{T}$ representing the integrated peak intensities of all linear, branched and terminal fragments, respectively.

\subsubsection{Buffer capacity}

The buffer capacity was determined by an acid-base titration. All polymers were dissolved with a concentration of $50 \mathrm{mM}$ of protonatable nitrogens in $150 \mathrm{mM} \mathrm{NaCl} .5$ $\mathrm{ml}$ of these solutions were taken out and the $\mathrm{pH}$ was adjusted to 2.0 using $\mathrm{IM} \mathrm{HCl}$. Subsequently, this solution was titrated with o.I $\mathrm{M} \mathrm{NaOH}$ to $\mathrm{pH}$ io using an automated titrator (Metrohm 702 SM Titrino). As a reference, the same procedure was applied to branched PEI $(25 \mathrm{~kg} / \mathrm{mol})$ and $\mathrm{I} 50 \mathrm{mM} \mathrm{NaCl}$ solutions. The buffer capacity is defined as the percentage of nitrogen becoming deprotonated from $\mathrm{pH}$ 5.I to $\mathrm{pH} 7.4$ and can be calculated from (I): 
Buffer capacity $=\frac{c_{\mathrm{NaOH}}\left(\Delta V_{\mathrm{p}}-\Delta V_{\mathrm{NaCl}}\right)}{n} \times 100 \%$

Where $\Delta V_{p}$ and $\Delta V_{\mathrm{NaCl}}$ are the volumes of $\mathrm{NaOH}$ solution added between $\mathrm{pH}$ 5.I and 7.4 to the polymer solution and a blank $\mathrm{NaCl}$ solution, respectively, and $n$ is total amount of protonatable nitrogens present in the polymer solution.

\subsubsection{Polyplex preparation}

Polyplexes at different polymer/nucleotide mass ratios were prepared in HEPES buffered glucose (HBG: $20 \mathrm{mM}$ HEPES, $\mathrm{pH}$ 7.4, $5 \mathrm{wt} \%$ glucose). The polymer solution was added to the nucleotide solution in a volume ratio of $4 / \mathrm{r}$, followed by $5 \mathrm{~s}$ vortexing and $30 \mathrm{~min}$ incubation at room temperature.

\subsubsection{Polyplex properties}

Polyplexes containing $6.25 \mu \mathrm{g} / \mathrm{ml}$ siRNA or Io $\mu \mathrm{g} / \mathrm{ml} \mathrm{pDNA}$ were prepared at five different polymer/nucleotide mass ratios (3/I, 6/I, I2/I, 24/I and 48/I) as described above. The hydrodynamic diameter and the $\zeta$-potential were measured by dynamic light scattering on a Zetasizer Nano ZS (Malvern Instruments) at $25^{\circ} \mathrm{C}$.

\subsubsection{Polyplex degradation}

Polyplexes containing $40 \mu \mathrm{g} / \mathrm{ml}$ siRNA or $20 \mu \mathrm{g} / \mathrm{ml}$ pDNA were prepared as described above at seven different polymer/siRNA mass ratios (0.75/I, I.5/I, 3/I, 6/I, I2/I, $24 / \mathrm{I}, 48 / \mathrm{I})$. To test polymer degradation by disulfide reduction, glutathione (GSH) or DTT were added $30 \mathrm{~min}$ after polyplex formation to obtain a final concentration of 15 $\mathrm{mM}$ GSH or $7.5 \mathrm{mM}$ DTT, corresponding with a three times excess of thiols over the disulfides in the polymer backbone in the highest polymer/siRNA ratio. After another 30 minutes (with or without GSH or DTT incubation), $15 \mu$ of polyplex solution was mixed with $3 \mu$ of loading buffer and transferred to an agarose gel (4.o wt\% for siRNA and $0.8 \mathrm{wt} \%$ for pDNA) containing I.25 $\mu \mathrm{M}$ ethidium bromide. Electrophoresis was performed for $60 \mathrm{~min}$ at $90 \mathrm{~V}$ in a TAE running buffer $(40 \mathrm{mM}$ tris(hydroxymethyl)aminomethane, $20 \mathrm{mM}$ acetic acid, Io mM EDTA, $\mathrm{pH} 8,0$ ) supplemented with I.25 $\mu \mathrm{M}$ ethidium bromide. After electrophoresis, pictures were taken on a Biorad Gel Doc 2000 under UV illumination and analyzed using Biorad Multi Analyst software version I.I. 


\subsubsection{In vitro gene silencing}

Knockdown efficiency was determined by silencing luciferase expression in $\mathrm{NCl}$ Hi299 cells, stably expressing firefly luciferase. Knockdown and cell viability were evaluated in two parallel sessions, using anti-luciferase and non-coding siRNA, respectively. Cells were seeded in 96 well plates with a density of 8000 cells per well. After $24 \mathrm{~h}$ incubation at $37^{\circ} \mathrm{C}$ in a humidified atmosphere containing $5 \% \mathrm{CO}_{2}$, medium was replaced with Ioo $\mu$ fresh medium without FBS. Polyplexes containing $6.25 \mu \mathrm{g} / \mathrm{ml}$ siRNA were prepared at five different polymer/siRNA mass ratios (3/I, 6/I, I2/I, 24/I and $48 / \mathrm{I}$ ) as described above. Lipofectamine 2000 was used as a reference and complexes were prepared according to the manufacturer's protocol. Polyplexes $(20 \mu \mathrm{l}$ per well) were added to the cells in triplo after I hour incubation with fresh medium, resulting in a final siRNA concentration of $66 \mathrm{nM}$. After 2 hours of transfection, polyplex medium was replaced by complete culture medium and the cells were incubated for another 48 hours. Cells were lysed in a freeze/thaw cycle and $50 \mu \mathrm{l}$ of the cell lysate was mixed with $50 \mu \mathrm{l}$ luciferase assay reagent containing the substrate luciferin. After Ioo - 220 seconds (in this timeframe the emitted light is constant - data not shown) the luciferase activity was determined by measuring the luminescence at $25^{\circ} \mathrm{C}$ for 4 seconds on a PerkinElmer I420 Victor ${ }^{3}$ plate reader. Luciferase activity of untreated cells was defined as $100 \%$ expression.

\subsubsection{Uptake of siRNA complexes}

The uptake of siRNA complexes was studied by flow cytometry using NCl-Hı299 cells. Cells were seeded in 24 well plates with a density of 48000 cells per well. After $24 \mathrm{~h}$ incubation at $37^{\circ} \mathrm{C}$ in a humidified atmosphere containing $5 \% \mathrm{CO}_{2}$, medium was replaced with 6oo $\mu$ l fresh medium without FBS. Polyplexes containing $6.25 \mu \mathrm{g} / \mathrm{ml}$ siRNA were prepared at five different polymer/siRNA mass ratios (3/I, 6/I, I2/I, 24/I and $48 / \mathrm{I}$ ) as described above using FITC labeled siRNA. Lipofectamine 2000 was used as a reference and complexes were prepared according to the manufacturer's protocol. Polyplexes ( $\mathrm{I} 2 \mathrm{O} \mu \mathrm{l}$ per well) were added to the cells in duplo after I hour incubation with fresh medium, resulting in a final siRNA concentration of $66 \mathrm{nM}$. After 2 hours of transfection, the cells were washed with PBS, trypsinized and suspended in PBS containing Io \% (v/v) FBS. The mean fluorescence intensity per cell was determined on a Becton Dickenson FACSCalibur flow cytometer.

\subsubsection{In vitro gene expression}

Transfection and cell viability experiments were performed with COS-7 cells or $\mathrm{NCl}-\mathrm{H} 1299$ cells using pCMV-GFP DNA as a reporter gene. Gene expression (green 
fluorescent protein) and cell viability (XTT) were evaluated in two separate parallel sessions. Cells were seeded in 96 well plates with a density of 8000 cells per well. After $24 \mathrm{~h}$ incubation at $37^{\circ} \mathrm{C}$ in a humidified atmosphere containing $5 \% \mathrm{CO} 2$, medium was replaced with Ioo $\mu \mathrm{l}$ fresh medium without FBS. Polyplexes containing Io $\mu \mathrm{g} / \mathrm{ml} \mathrm{pDNA}$ were prepared at five different polymer/siRNA mass ratios (3/I, 6/I, I2/I, 24/I and 48/I) as described above. Linear PEI (Exgen 500, N/P = 5/I) was used as a reference. Optimized transfection conditions were used and Ioo $\mu$ of polyplex solution was added to the cells in quinto after I hour incubation with fresh medium. After I hour of incubation, polyplex medium was replaced by complete culture medium and the cells were incubated for another 48 hours. Transfection efficiency was determined by measuring the GFP expression on a Magellan Tecan Safire Il 96 wells plate reader. Excitation was at $480 \mathrm{~nm}$ and optimal emission was determined at $503 \mathrm{~nm}$. Cell viability was assessed by an XTT proliferation assay in which untreated cells were defined as Ioo\% viable. $48 \mathrm{~h}$ after transfection the cells were washed and incubated for I hour in colorless culture medium supplemented with $0.5 \mathrm{mM}$ XTT and $25 \mu \mathrm{M}$ PMS. Absorption of the orange colored formazan salt, formed by metabolic active cells, was determined on a Magellan Tecan Safire Il 96 wells plate reader at $450 \mathrm{~nm}$ in colorless culture medium.

\subsubsection{Hemolysis}

Hemolytic activity of the polymers was tested as described by Meyer [I6] with a few modifications. Human erythrocytes were isolated from freshly obtained citrate treated blood by washing and centrifugation in PBS four times $\left(800 \mathrm{~g}\right.$, Io $\left.\mathrm{min}, 4^{\circ} \mathrm{C}\right)$. After the final washing step, the erythrocyte pellet was diluted to times in $150 \mathrm{mM} \mathrm{NaCl}$. Polymer solutions were prepared in HBS (HEPES buffered saline, 20 mM HEPES, pH 7.4, 130 $\mathrm{mM} \mathrm{NaCl})$ at $\mathrm{I} .25 \mathrm{mg} / \mathrm{ml}$ and were diluted 7 times. Triton X-Ioo I\% (v/v) in HBS was used as a positive control; plain HBS served as negative control. All solutions were filled out in triplicate in $120 \mu \mathrm{l}$ portions in a V-bottom 96 well plate and the plates were preincubated at $37^{\circ} \mathrm{C}$ for $20 \mathrm{~min}$. Then $30 \mu \mathrm{l}$ of erythrocyte suspension was added and the plates were incubated at $37^{\circ} \mathrm{C}$ under constant shaking. After $30 \mathrm{~min}$, the plates were centrifuged ( $300 \mathrm{~g}$, Io $\mathrm{min}, 20^{\circ} \mathrm{C}$ ), $60 \mathrm{\mu l}$ of supernatant was transferred to a flat bottom 96 well plate and were analyzed for hemoglobin absorption at $405 \mathrm{~nm}$ using a plate reader (Magellan Tecan Safire II). 


\subsection{Results and discussion}

\subsubsection{Synthesis and characterization of the copolymers}

A series of $\mathrm{p}(\mathrm{CBA}-\mathrm{ABOL} / \mathrm{EDA})$ and $\mathrm{p}(\mathrm{CBA}-\mathrm{ABOL} / \mathrm{TETA})$ copolymers were synthesized at five different compositions, containing Ioo/o, 75/25, 50/50, 25/75, o/ıоo percent ratio of $\mathrm{ABOL} / \mathrm{EDA}$ or $\mathrm{ABOL} / \mathrm{TETA}$ in the amino monomeric units, respectively. Every polymer was obtained as a brittle white material with a final ABOL/EDA or ABOL/TETA composition approximating the feed compositions (Table 3.I) as was determined from their ${ }^{\mathrm{I}} \mathrm{H}$ NMR spectra. This indicates that the polymerization reactions are very well controllable.

Table 3.1: Synthesis characteristics.

\begin{tabular}{|c|c|c|c|c|c|c|c|}
\hline & $\begin{array}{l}\text { Feed } \\
\text { composition }^{\mathrm{a}}\end{array}$ & $\begin{array}{l}\text { Aimed } \\
\text { composition }^{\text {b }}\end{array}$ & Yield $(\%)^{c}$ & 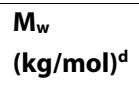 & $\mathrm{PDI}^{\mathrm{d}}$ & $\begin{array}{l}\text { Degree of } \\
\text { branching }^{\mathrm{e}}\end{array}$ & $\begin{array}{l}\text { Buffer } \\
\text { capacity }\end{array}$ \\
\hline & $100 / 0$ & & 27 & 4.1 & 1.4 & - & $72 \%$ \\
\hline $\mathrm{ABOL}$ & $75 / 25$ & $80 / 20$ & 50 & 11.7 & 2.4 & 0.01 & $71 \%$ \\
\hline / & $50 / 50$ & $55 / 45$ & 57 & 7.2 & 1.9 & 0.02 & $53 \%$ \\
\hline \multirow[t]{3}{*}{ EDA } & $25 / 75$ & $30 / 70$ & 53 & 3.1 & 1.6 & 0.04 & $41 \%$ \\
\hline & $0 / 100$ & & 45 & 1.6 & 1.6 & 0.06 & $29 \%$ \\
\hline & $100 / 0$ & & 27 & 4.1 & 1.4 & - & $72 \%$ \\
\hline ABOL & $75 / 25$ & $70 / 30$ & 51 & 10.7 & 2.2 & 0.07 & $54 \%$ \\
\hline / & $50 / 50$ & $45 / 55$ & 44 & 6.7 & 1.5 & 0.10 & $40 \%$ \\
\hline \multirow[t]{2}{*}{ TETA } & $25 / 75$ & $20 / 80$ & 59 & 6.4 & 1.5 & 0.45 & $31 \%$ \\
\hline & $0 / 100$ & & 65 & 6.5 & 1.4 & 0.32 & $18 \%$ \\
\hline
\end{tabular}

(a) Stoichiometrical feed ratio of monomers; (b) Determined by ${ }^{1} \mathrm{H} N \mathrm{NR}$; (c) After ultrafiltration; (d) Determined by GPC; (e) Determined by mass spectrometry; (f) Buffer capacity of b-PEl $(25 \mathrm{~kg} / \mathrm{mol}$ ) is $15 \%$ (measured under the same conditions).

The yields of the polymerizations after ultrafiltration with a $\mathrm{I} \mathrm{kg} / \mathrm{mol}$ cut off filter were generally about 50\% (Table 3.I), except the polymer containing I00\% ABOL that was isolated in $27 \%$ yield. The lower yield of this polymer can be explained by the lower reactivity of the secondary amine at an $\mathrm{ABOL}$ terminal polymer chain in the Michael addition compared to the reactivity of a terminal primary amine of EDA or TETA. It also resulted in the slightly lower molecular weight of this polymer. The molecular weights of the copolymers are ranging between 2 and $7 \mathrm{~kg} / \mathrm{mol}$ and the polymers show approximately similar polydispersities.

Since the (formed) secondary amines from EDA or TETA can also be reactive in the Michael reaction, there is a possibility to form branched polymer structures. Although 
the basicity and also the nucleophilic reactivity is in general higher for secondary than for primary amines, the additional reaction of the secondary amines in the polymer chain onto the acrylamide moiety is expected to proceed slower because of the higher sterically hindered reaction site [I7]. Nevertheless, the degree of branching can play a role in complex formation and transfection properties, as was extensively investigated for PEI, in favor of the linear polymer [I8-I9]. It may be expected that the degree of branching increases upon an increased concentration of secondary amines in the reaction solution, which was indeed found for the obtained copolymers (Table 3.I).

\subsubsection{Buffer capacity}

It is often observed that the capacity of cationic polymers to buffer the decrease in endosomal $\mathrm{pH}$ ( $\mathrm{pH} 7.4$ to $\mathrm{pH}$ 5.I) promotes the release of polyplexes into the cytosol. Although there is some debate whether this release is the result of the so-called proton sponge effect [I] or (also) due to other factors, like increased protonation and conformational changes of the polymer resulting in increased membrane interactions and membrane lysis, our previous studies with poly(amido amine)s suggest that there is a good correlation between buffer capacity and transfection efficiency for these polymers [IO, I2]. The buffer capacities were determined by acid-base titrations and a lower slope in the pH range 7.4-5.I in the titration curves (Figure 3.I) corresponds with a higher buffer capacity.
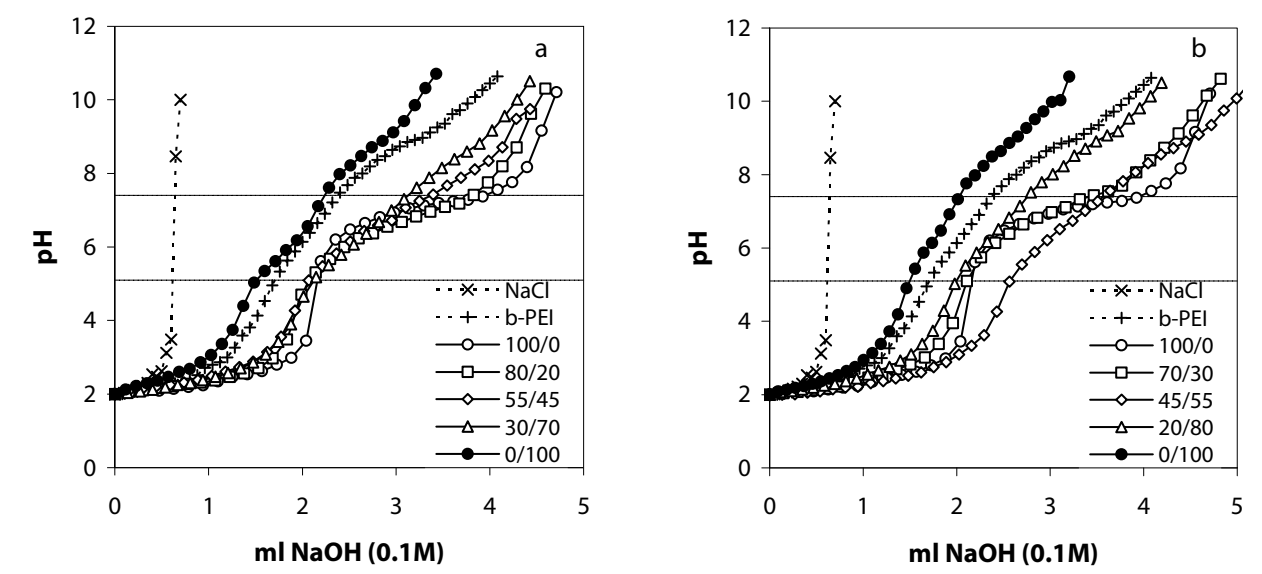

Figure 3.1: Titration curves of $p(C B A-A B O L / E D A)(a)$ and $p(C B A-A B O L / T E T A)$ (b) obtained by titration of 0.25 $\mathrm{mmol}$ protonatable nitrogens (polymer) with $0.1 \mathrm{M}$ sodium hydroxide solution.

The data in Table 3.I show that the buffer capacities of the copolymers decrease with decreasing amount of $\mathrm{ABOL}$ in the polymer, which could be expected since the $\mathrm{ABOL}$ nitrogen has a $\mathrm{pK}_{\mathrm{a}}$ value (ca. 7) that is right in the middle of the endosomal buffer

56. Chapter 3 
range [10, I5]. Furthermore, it is clear from the graphs and buffer capacity values, that the polymers containing less $\mathrm{ABOL}$ are approximating the curve of $\mathrm{PEI}$ more and more, reflecting the chemical similarity of the protonable nitrogens in these polymers.

\subsubsection{Polyplex properties}

A prerequisite for cationic polymers to function as gene delivery vectors is that they are able to condense

nucleotides into nanosized

polyplexes. Figure 3.2 shows the sizes and surface charges of polyplexes of siRNA and pDNA from polymer/nucleotide weight ratios varying from 3/I to 48/I.

For the pDNA polyplexes (Figure 3.2a, b), the replacement of only $25 \%$ ABOL by EDA or TETA already significantly reduces the amount of polymer needed for the formation of small polyplexes. Further increase of the EDA or TETA content in the polymer even further reduces the amount of polymer needed for small polyplexes. The $\zeta$-potential of the polyplexes formed with the $\mathrm{p}(\mathrm{CBA}-\mathrm{ABOL})$ homopolymer increases rapidly with increasing the polymer/pDNA ratios. For the polyplexes from the EDA or TETA containing polymers, $\zeta$-potentials remain generally constant for all the measured ratios, independent of the fraction of EDA or TETA.
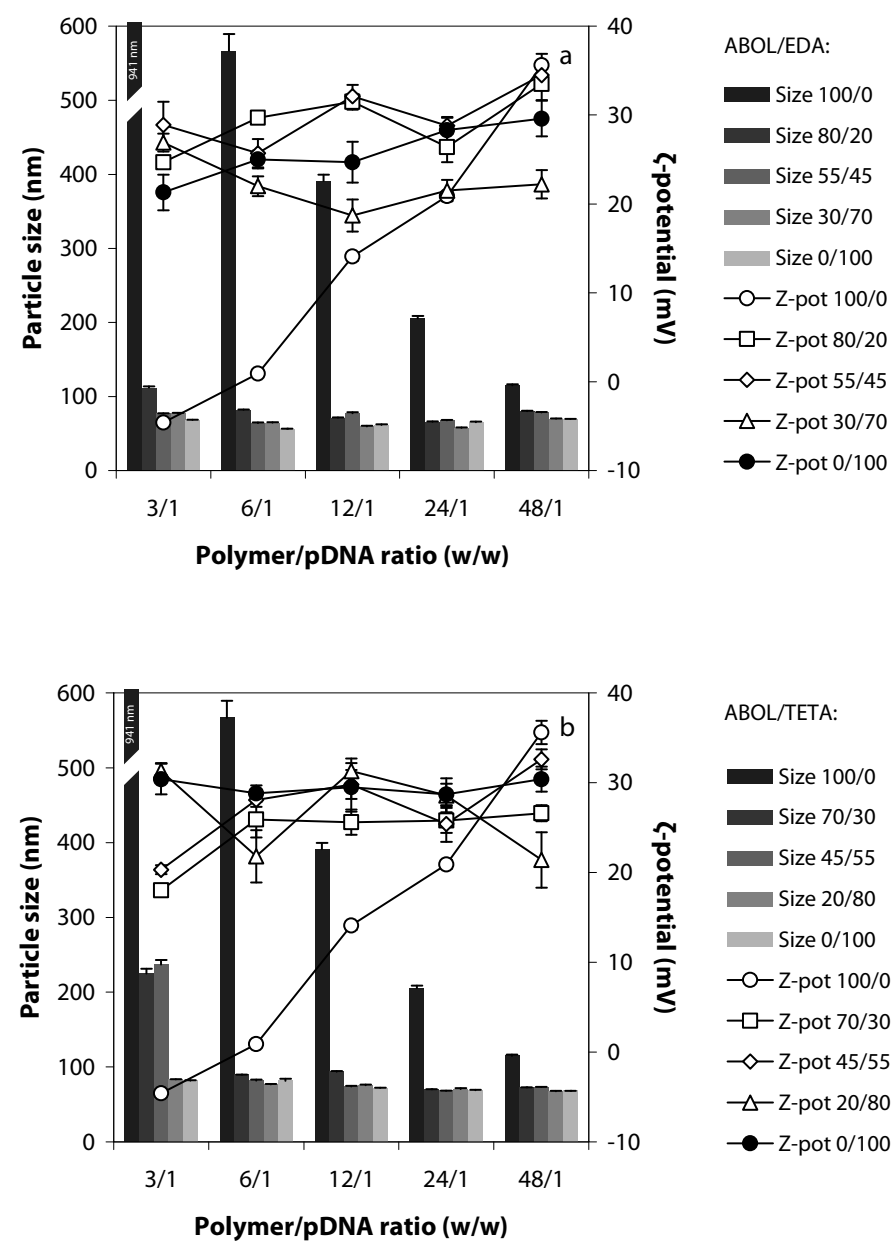

Figure 3.2: Particle size (bars) and $\zeta$-potential (lines) of pDNA containing polyplexes formed at several $w / w$ ratios with $p(C B A-A B O L / E D A)$ (a) and $\mathrm{p}(\mathrm{CBA}-\mathrm{ABOL} / \mathrm{TETA})(\mathrm{b})$. 
the Considering

polyplexes (Figure

3.3c, d), the p(CBA-

ABOL)

homopolymer,

lacking EDA or

TETA, is only able to condense siRNA into small polyplexes at the high 48/I ratio. Incorporation of

EDA or TETA significantly

improves the formation of small polyplexes, but compared to pDNA either more polymer or a higher fraction of EDA or TETA is necessary. When comparing EDA and TETA polymers

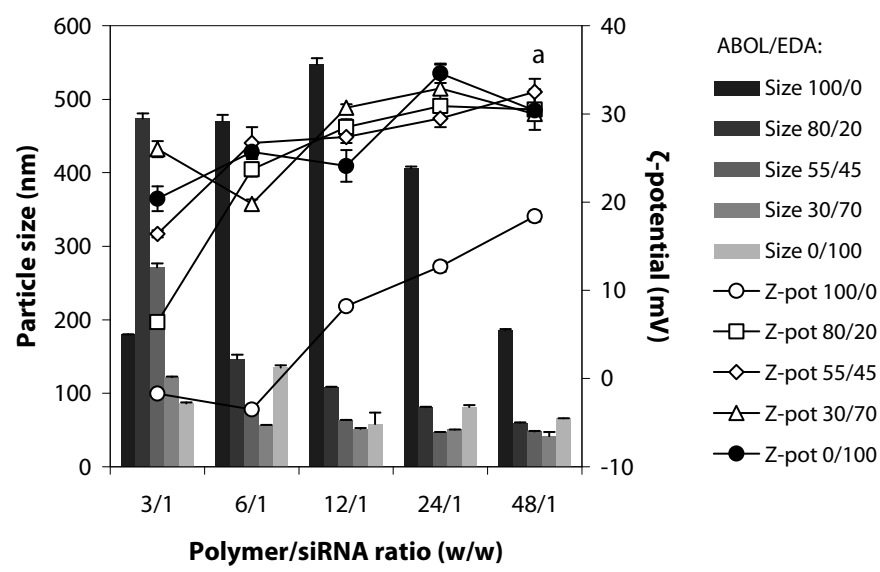
with each other, TETA polymers perform slightly better in the

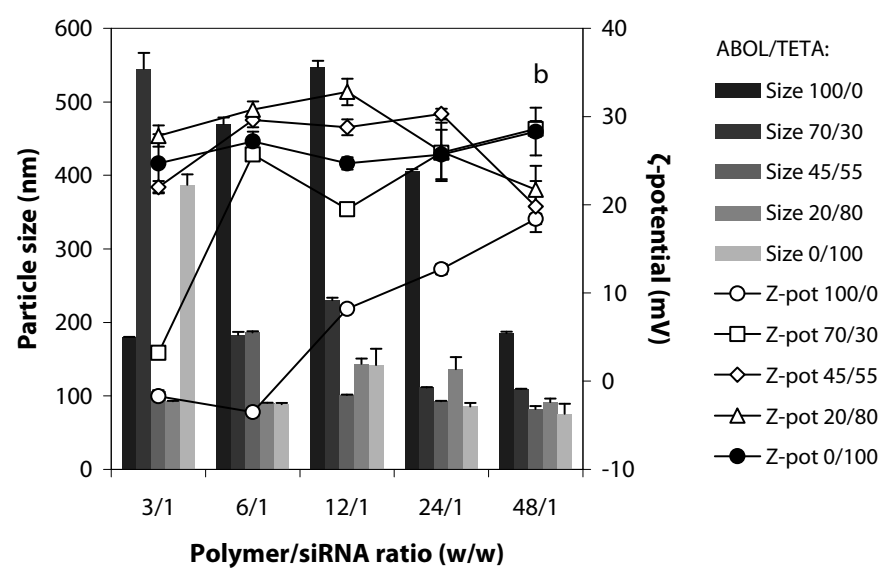

formation of small

polyplexes, especially for the low polymer/siRNA ratios. The $\zeta$-potentials of the siRNA polyplexes follow the same trend as the pDNA polyplexes, although the surface charge is slightly lower at lower polymer/siRNA ratios.

In general it can be concluded that the $\mathrm{p}(\mathrm{CBA}-\mathrm{ABOL})$ homopolymer, not possessing additional positively charged sites in the backbone, is only capable to form small polyplexes at 24/I and 48/I ratio with pDNA and at 48/I with siRNA. Furthermore, already a small amount of EDA or TETA in the polymer main chain greatly improves the capability to form small polyplexes with siRNA and pDNA from much lower ratios.

58 - Chapter 3 


\subsubsection{Polyplex degradation}

For efficient gene transfer, the polyplexes should protect the DNA or siRNA in the extracellular environment against nucleases. Once in the cytosol, polymer degradation should be fast to release the polynucleotides from the polymeric vector. Insufficient condensation during polyplex preparation as well as insufficient unpacking of polyplexes inside the cell forms a major barrier in the transfection process. Consequently, the rapid cleavage of the disulfide linkages in the intracellular reductive environment (containing 0.I-Io mM glutathione) as is schematically depicted in Figure 3.4, is biologically relevant to induce fast disassembling of the polyplexes and efficient gene release, leading to increased levels of gene expression.

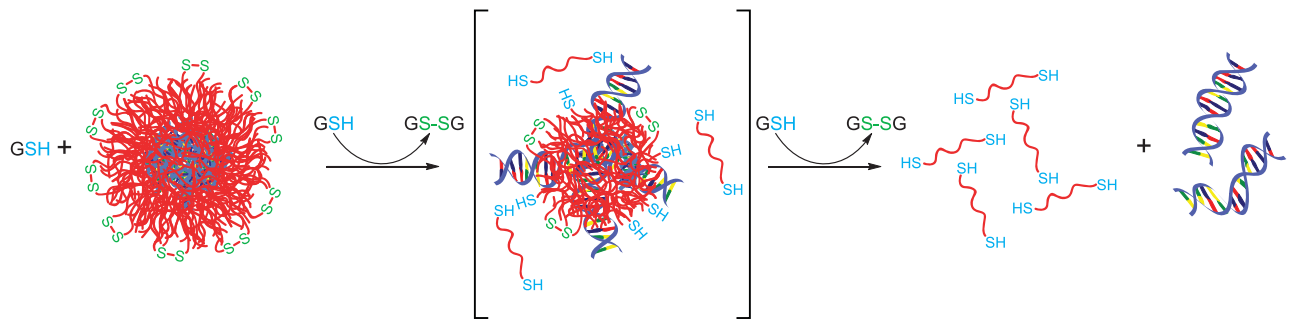

Figure 3.4: Schematic representation of the polyplex degradation and nucleic acid release upon disulfide reduction in presence of glutathione (GSH).

In order to prove the concept of efficient unpacking and release of genes from the polyplexes upon disulfide reduction, the complexation-decomplexation behavior of siRNA and pDNA polyplexes was investigated by agarose gel retardation. The retardation pictures of polyplexes prepared from $\mathrm{p}(\mathrm{CBA}-\mathrm{ABOL}), \mathrm{p}\left(\mathrm{CBA}-\mathrm{ABOL}_{55} / \mathrm{EDA}_{45}\right)$ and $\mathrm{p}\left(\mathrm{CBA}^{-\mathrm{ABOL}_{45}} / \mathrm{TETA}_{55}\right)$ at weight ratio's 0.75/I, I.5 /I, 3/I, 6/I, I2/I, 24/I and 48/I are given in Figure 3.5. These pictures show that the $\mathrm{p}(\mathrm{CBA}-\mathrm{ABOL})$ homopolymer retards the migration of pDNA from w/w ratio I2/I, but siRNA only from ratio 24/I. The more positively charged polymers retard the migration of the negatively charged siRNA or pDNA from $\mathrm{w} / \mathrm{w}$ ratio $3 / \mathrm{I}$ and $\mathrm{I} .5 / \mathrm{I}$ and higher for respectively the EDA and TETA containing polymer. Up to ratio 6/I ethidium-polynucleotide complexes are still visible in the starting wells, but not in the gel, which means that the polynucleotides were still bound by the polymer, but not completely shielded from ethidium complexation. For the other polymers (data not shown), complete retardation of siRNA was observed from polymer/siRNA weight ratios I2/I, 6/I, 3/I, 3/I and I.5/I for p(CBA-ABOL/EDA) with $\mathrm{ABOL} / \mathrm{EDA}$ ratios I0o/o, 80/20, 55/45, 30/70 and o/100, respectively and from polymer/siRNA weight ratios I2/I, 3/I, I.5/I, I.5/I and I.5/I for p(CBA-ABOL/TETA) with ABOL/TETA ratios 10o/o, 70/30, 45/55, 20/80 and o/100, respectively. Complete retardation of pDNA was slightly more efficient (data not shown) and was observed from polymer/pDNA weight ratios 6/I, 3/I, 3/I, I.5/I and I.5/I for p(CBA-ABOL/EDA) 
with $\mathrm{ABOL} / \mathrm{EDA}$ ratios 100/0, 80/20, 55/45, 30/70 and o/100, respectively and from polymer/pDNA weight ratios 6/I, 3/I, I.5/I, I.5/I and I.5/I for p(CBA-ABOL/TETA) with ABOL/TETA ratios Ioo/o, 70/30, 45/55, 20/80 and o/Ioo, respectively. These complexation data are perfectly in line with the $\zeta$-potential measurements in the sense that no migration of nucleotides was observed for positively charged particles.

a

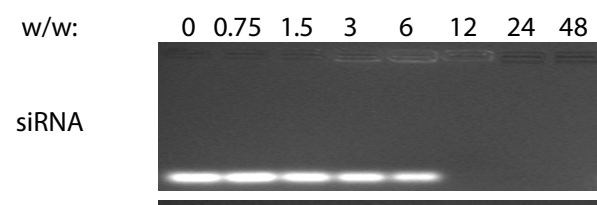

pDNA

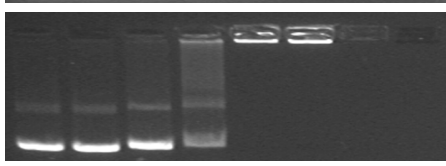

In absence of DTT
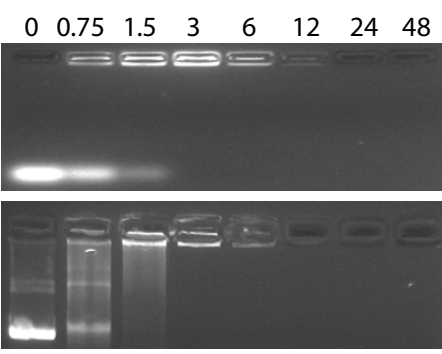

In absence of DTT

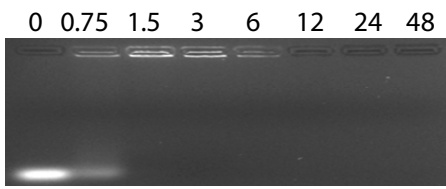

pDNA

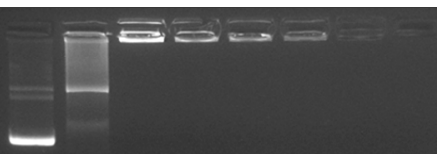

In presence of DTT

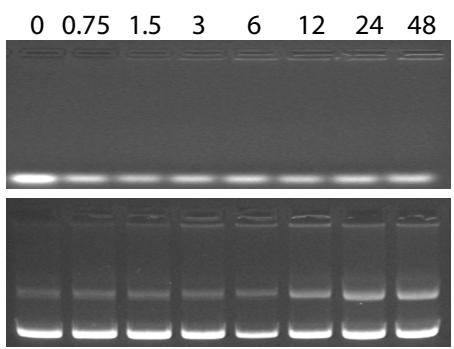

In presence of DTT

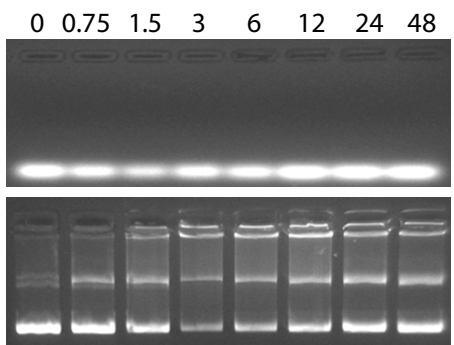

In presence of DTT

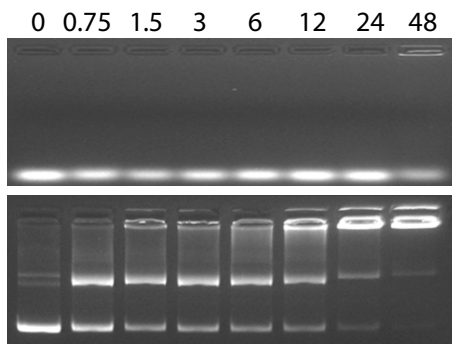

Figure 3.5: Gel retardation profiles of polyplexes from $p(C B A-A B O L)(a), p\left(C B A-A B O L_{55} / E D A_{45}\right)(b)$ and $p(C B A-$ $\mathrm{ABOL}_{45} / \mathrm{TETA}_{55}$ ) (c) at w/w ratios from 0 (siRNA or pDNA only) to 48 with siRNA (first rows) and pDNA (second rows) incubated in presence (right) or in absence (left) of $2.5 \mathrm{mM} \mathrm{DTT}$.

Incubation of the polyplexes for $30 \mathrm{~min}$ in the presence of the reducing agent dithiothreitol (DTT, 2.5 mM) mimicking the reducing intracellular environment,

$60 \cdot$ Chapter 3 
resulted in polynucleotide release from the fragmented polyplexes (Figure 3.5, right columns). siRNA containing polyplexes showed siRNA release at all polymer/siRNA ratios for both the EDA and TETA containing polymer. pDNA containing polyplexes from the EDA containing polymer showed pDNA release at all polymer/pDNA ratios as well, whereas these of the TETA containing polymer only showed total release at lower ratios. The residual ethidium-pDNA complexes observed at the starting wells for the I2/I, 24/I and 48/I ratios indicate that these higher polymer concentrations of TETA containing polymer fragments were still able to bind some pDNA.

\subsubsection{In vitro gene silencing and cytotoxicity by siRNA transfection}

The silencing potential by siRNA polyplexes of the copolymers was evaluated by determination of the knockdown of luciferase expression in Hi299 cells that stably express this enzyme. The optimal transfection time was determined to be 2 hours; longer times did not enhance transfection, but had a negative effect on the cell viability (data not shown). The luciferase activity of the lysed cells 48 hours after transfection was measured by the luminescent oxidation of luciferin to oxyluciferin. Silencing experiments were consciously carried out in absence of serum, to get a better insight in the structure-function relationship of the synthesized polymers towards their biological properties. In Figure 3.6 the relative luciferase expression is given after treatment with $\mathrm{p}(\mathrm{CBA}-\mathrm{ABOL} / \mathrm{EDA})$ and $\mathrm{p}(\mathrm{CBA}-\mathrm{ABOL} / \mathrm{TETA})$ complexes with anti-luciferase or noncoding siRNA, as calculated from the percentage of the emitted light in this reaction, with untreated cells defined as having Ioo\% luciferase expression. Lipofectamine 2000 was included as a reference. The luciferase expression of the polymers with the highest EDA and TETA contents are not displayed, since they show complete cell death from ratio I2/I and higher and do not show any significant knockdown at lower ratio's.

Generally, it was observed that the EDA containing polyplexes showed better knockdown and lower cytotoxicity than the TETA containing analogs. Although the polyplex properties are comparable for both polymer series, an explanation of the lower knockdown for TETA polymers may be in the poorer siRNA release upon polymer degradation. The highly charged TETA fragments may still adhere to the siRNA, as was also shown in the gel retardation experiments, and consequently may inhibit the RISC activation. Moreover, the higher cytotoxicity observed for the TETA polymers can be a result of increased membrane interactions, as is supported by the higher hemolytic activity of these polymers (vide infra). An increase in charge density in the transfection agent had also a large negative effect on the cell viability, as can be seen in Figure 3.6c, d, e and $f$, where toxicity increases with increasing EDA or TETA content at the highest polymer/siRNA ratios. 


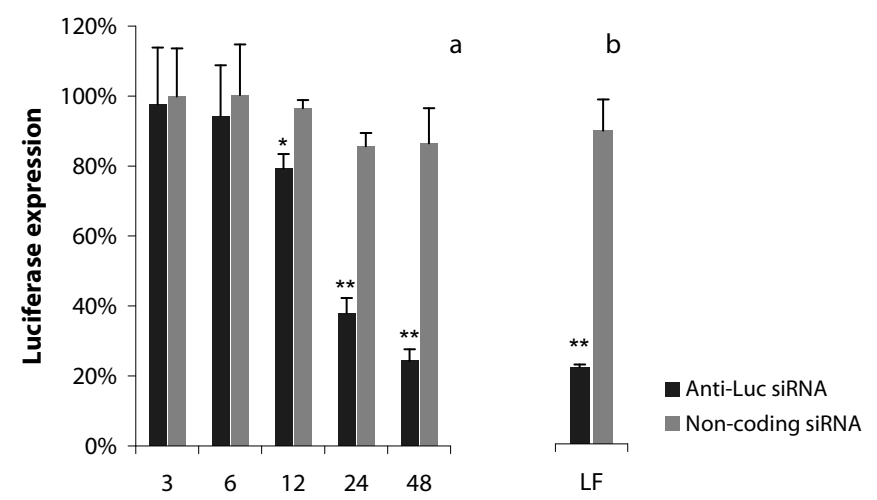

Polymer/siRNA (w/w)
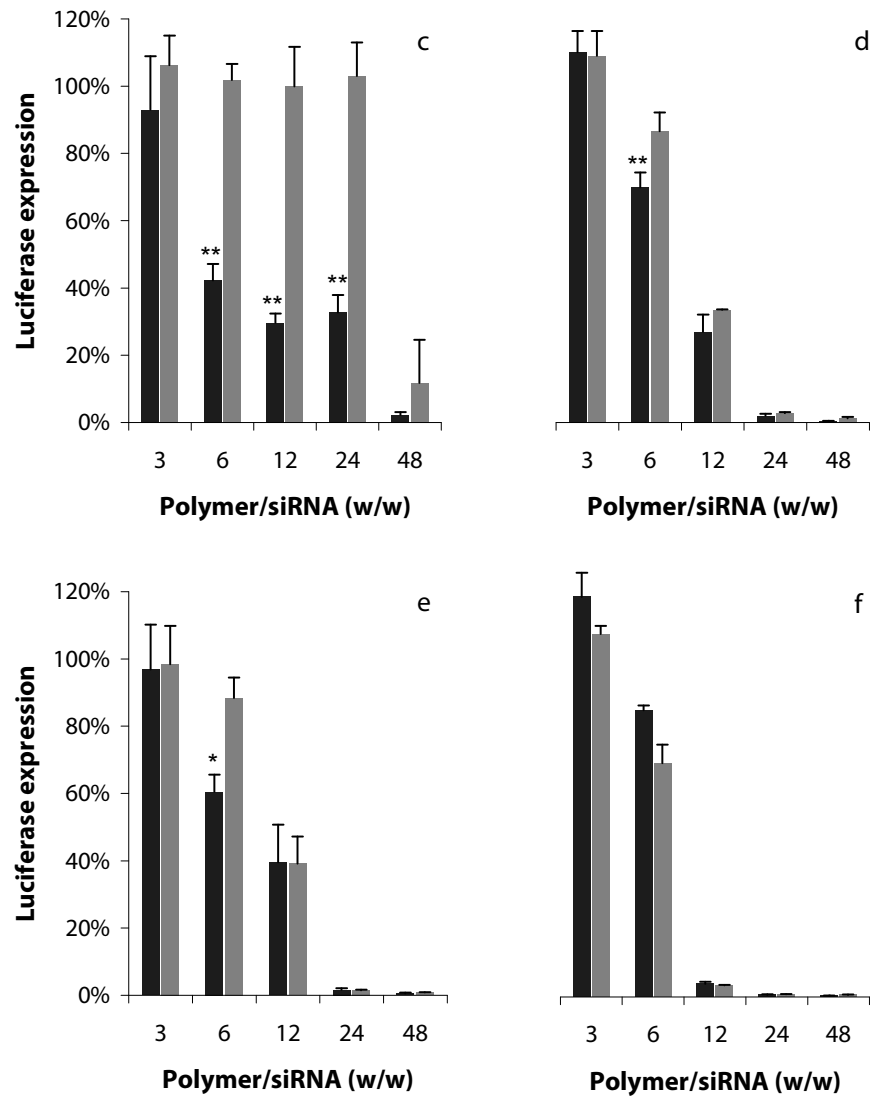

Figure 3.6: Luciferase expression of $\mathrm{H} 1299$ Fluct cells 48 hours after transfection with anti-luciferase siRNA (black) and non-coding control siRNA (grey) with $\mathrm{p}(\mathrm{CBA}-\mathrm{ABOL})$ (a), p(CBA-ABOL $\left.80 / \mathrm{EDA}_{20}\right)$ (c), p(CBA$\left.\mathrm{ABOL}_{55} / \mathrm{EDA}_{45}\right)(\mathrm{d}), \mathrm{p}\left(\mathrm{CBA}-\mathrm{ABOL}_{70} / \mathrm{TETA}_{30}\right)(\mathrm{e}), \mathrm{p}\left(\mathrm{CBA}_{\mathrm{ABOL}} / \mathrm{TETA}_{55}\right)$ (f). Lipofectamine 2000 (LF) was used as reference transfection agent (b). Each bar value represents the mean $\pm S D$ of $n=3$. For statistical analysis of differences between anti-luciferase and non-coding siRNA an unpaired Student's t-test was used $\left({ }^{*} p<0.05\right.$; $\left.{ }^{* *} p<0.01\right)$.

62 - Chapter 3 
The highest knockdown and lowest cytotoxicity is observed for the $\mathrm{p}(\mathrm{CBA}-\mathrm{ABOL})$ homopolymer (at high polymer/siRNA ratio) and for the EDA polymers with low EDA content. The presence of $20 \%$ EDA really boosts the silencing, which is most significant for the 6/I and I2/I ratios. Silencing efficiencies comparable to Lipofectamine 2000 are achieved, which is currently the leading transfection reagent for siRNA. A possible explanation for this boosting can be found in the higher charge density in the polymer.

Transfection with the $\mathrm{p}(\mathrm{CBA}-\mathrm{ABOL})$ homopolymer is only significant at polymer/siRNA ratios $24 / \mathrm{I}$ and higher, where particles with high $\zeta$-potentials are formed. In the copolymers with only $20 \%$ EDA, however, such positively charged particles are already formed at 6/I ratio. Although the circumstances in the DLS measurements are not comparable to transfection, it is clear that in the last case less material is required due to its higher charge density When the EDA content is further increased above $20 \%$, or when TETA is present instead of EDA, the silencing potential becomes negligible. As discussed above, this may be due to adherence of positively charged polymer fragments to siRNA and / or incomplete unpacking. Furthermore, these highly charged polymers are also rather toxic, leading to almost complete cell death at weight ratios I2/I and higher.

For a better understanding of the silencing properties, cellular uptake of siRNA polyplexes of $\mathrm{p}(\mathrm{CBA}-\mathrm{ABOL})$, $\mathrm{p}\left(\mathrm{CBA}-\mathrm{ABOL}_{80} / \mathrm{EDA}_{20}\right)$ and $\mathrm{p}(\mathrm{CBA}-$ $\mathrm{ABOL}_{70} / \mathrm{TETA}_{30}$ ) was studied by flow cytometry. From Figure $3.7 \mathrm{a}$ it becomes clear that polyplexes are already taken up by almost every cell even at the lowest used weight ratios. The uptake is quantified by the mean
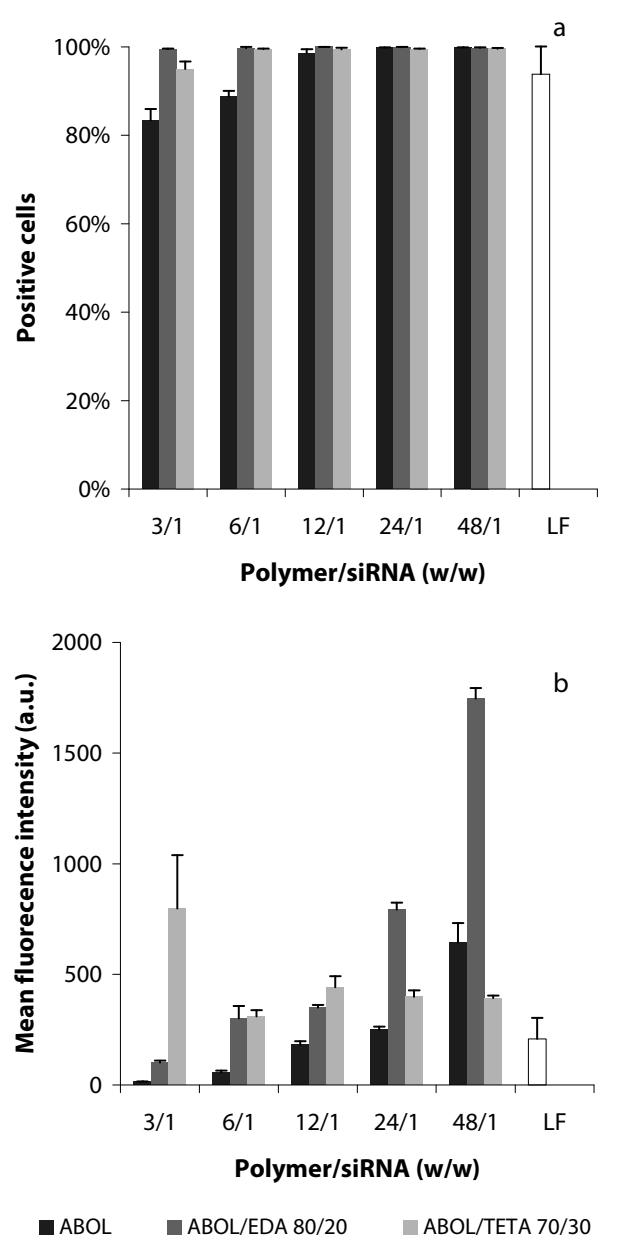

Figure 3.7: Uptake of FITC labeled siRNA complexed by $\mathrm{p}(\mathrm{CBA}-\mathrm{ABOL})$ (black), $\mathrm{p}\left(\mathrm{CBA}-\mathrm{ABO} \mathrm{L}_{80} / \mathrm{EDA}_{20}\right.$ ) (dark grey) and $\mathrm{p}\left(\mathrm{CBA}-\mathrm{ABOL}_{70} / \mathrm{TETA}_{30}\right.$ ) (light-grey) in $\mathrm{H} 1299$ cells: positive gated cells (a) and the mean fluorescence intensity per cell (b). 
fluorescence intensity (Figure 3.7b). Although it is difficult to draw solid conclusions from these data, since the mean fluorescence intensities can be lower due to quenching effects, as we published before [20], we learned in that study that SS-PAAs with a higher charge density undergo more quenching than their lower charged analogs. Thus it is reasonable to assume that the uptake of siRNA not only increases with increasing polymer/siRNA weight ratio, but also with increased charge density of the polymer. At weight ratios higher than I2/I, the TETA containing polymer is breaking this trend, which is most probably explained by the acute toxicity of this polymer at high ratios.
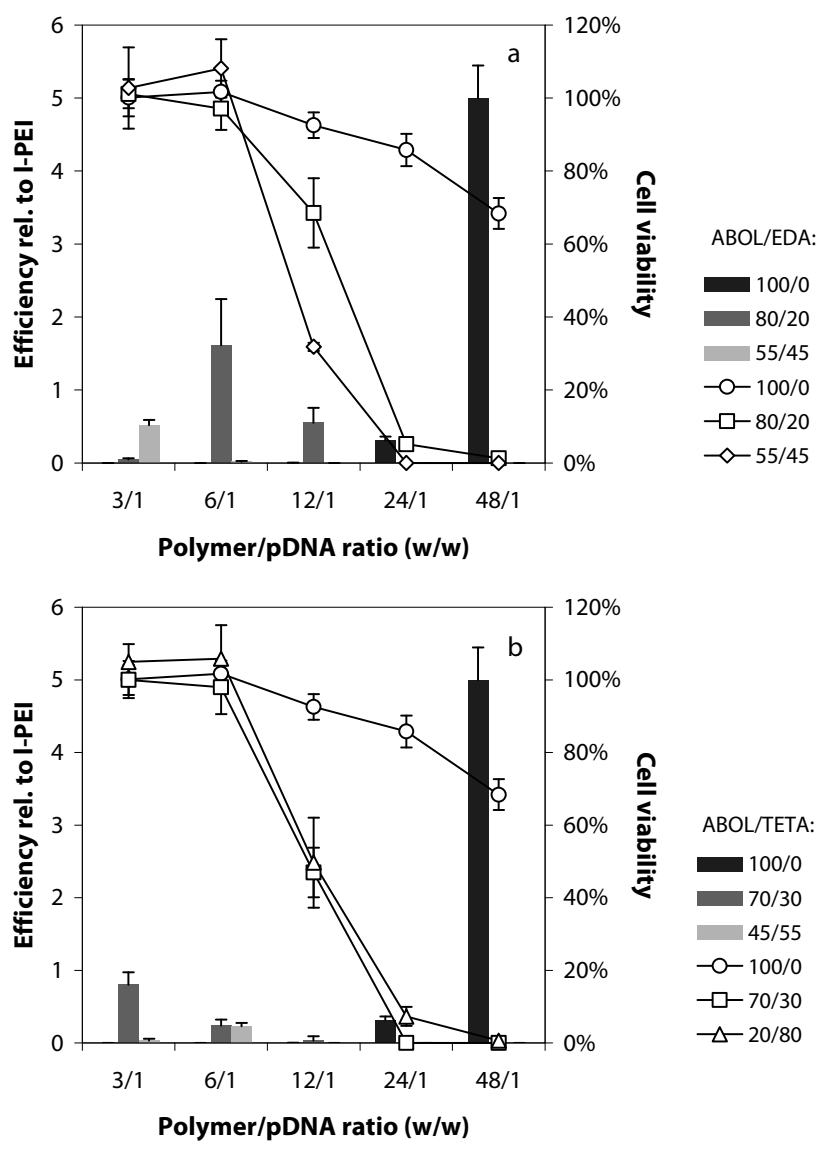

Figure 3.8: Transfection efficiencies (bars) and cell viabilities (lines) in $\mathrm{H} 1299$ cells after $2 \mathrm{~h}$ incubation and 48 hours after transfection relative to I-PEI (Exgen 500) with (a) $\mathrm{p}(\mathrm{CBA}-\mathrm{ABOL} / \mathrm{EDA})$ and (b) $\mathrm{p}(\mathrm{CBA}-\mathrm{ABOL} / \mathrm{TETA})$ copolymers. Each data point represents the mean $\pm S D$ of $n=4$ or 5
Toxic behavior for this polymer as was also observed in gene silencing and hemolysis (vide infra) and confirmed by significantly increased levels of cell debris found in the high weight ratio samples (data not shown). Although at low polymer/siRNA weight ratios cells were gated positive (Figure 3.7a), significant knockdown (Figure 3.6) was only found for cells showing a significant mean fluorescence intensity ( $\geq 200$ a.u. in Figure 3.7b). At lower fluorescence values, the amount of siRNA in the cells is probably too low to be effective, or too little polymer is present to induce sufficient endosomal escape. The data in Figure 3.7 once again underline that the presence of EDA in the polymer results in more efficient uptake of the polyplexes and lower polymer/siRNA ratios can be used. 


\subsubsection{In vitro gene expression and cytotoxicity by pDNA}

The pDNA transfection efficiencies of the copolymers were evaluated by determination of the GFP expression in Hi299 cells after transfection with a pCMVGFP DNA reporter gene, using linear PEI (Exgen 500) as a reference polymer (Figure 3.8). In a parallel session the cell viability was examined using an XTT assay. Again, the transfection experiments were performed in serum free conditions to get a good insight in the structure-function relationship of these polymers. Transfection of $\mathrm{p}(\mathrm{CBA}-\mathrm{ABOL})$ (without extra amines) is ca. five times more efficient than linear PEI that is currently the standard in pDNA transfections. Moreover, no significant cytotoxicities are observed. These results match with our previous work in COS-7 cells [1o]. For the copolymers with additional EDA or TETA it can be observed that a low percentage of extra amines yields a substantial transfection efficiency in the range of I to 2 times the efficiency of linear PEI. However, these efficiencies are reached at lower $\mathrm{w} / \mathrm{w}$ ratios than $\mathrm{p}(\mathrm{CBA}-\mathrm{ABOL})$ with a maximum at $6 /$ I. At higher w/w ratios the copolymers become cytotoxic, which suppresses the transfection efficiency.

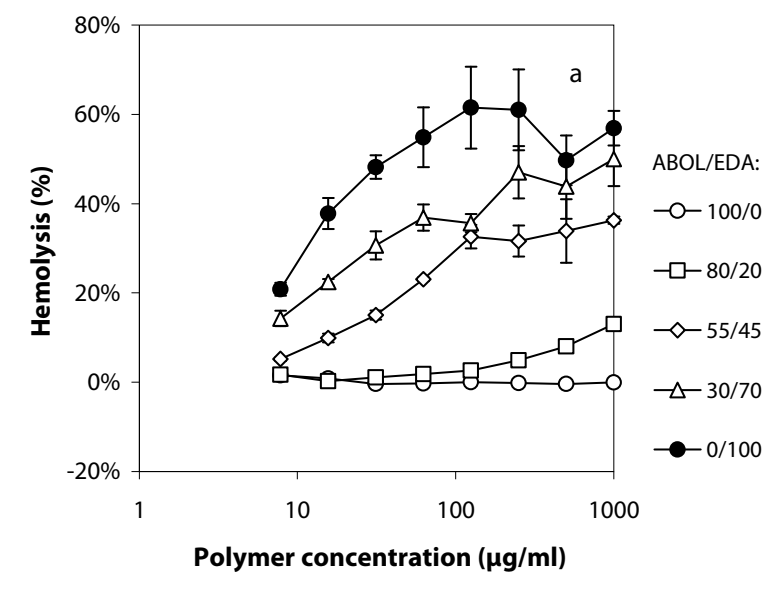
Copolymers containing more than $50 \%$ of EDA or TETA are also highly cytotoxic and do not show any gene expression (data not shown).

\subsubsection{Hemolysis}

Cationic and hydrophobic species are known to interact with lipid cell membranes. These interactions may be beneficial for cell attachment and finally endosomal uptake of gene vectors. However, when these interactions are too intensive, it

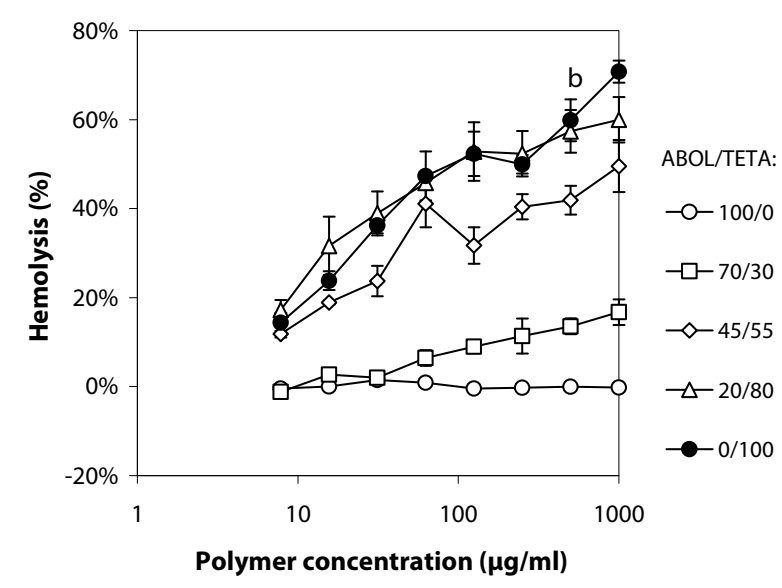

Figure 3.9: Hemoglobin leakage from human erythrocytes after 30 min incubation in (a) $\mathrm{p}(\mathrm{CBA}-\mathrm{ABOL} / \mathrm{EDA})$ polymer solutions and (b) $p(C B A-A B O L / T E T A)$ polymer solutions. 
may also result in damaging of cell membranes, leading to cytotoxic side effects. To test the compatibility of the polymers with cell membranes, the hemolytic activity as a function of the concentration of the polymers was investigated against human erythrocytes. The hemoglobin release after incubation with the polymers is plotted in Figure 3.9. Most notably, the $\mathrm{p}(\mathrm{CBA}-\mathrm{ABOL})$ homopolymer, lacking extra amines, is not hemolytic at all, which is in accordance with the absence of toxicity as found in the transfection experiments. However, the introduction of EDA or TETA moieties in the polymer chain increases the hemolytic activity, indicating that the hemolytic activity for these polymers is primarily determined by cationic interactions. The hemolytic activities of these polymers are in agreement with the toxicity profiles of the transfection experiments. Although there are differences in the degree of toxicity for the two cell types, the general trend is identical in that increase in toxicity, as observed in the transfection experiments, goes hand in hand with increasing hemolysis. Furthermore, hemolysis at $\mathrm{pH}_{5}$ did not differ significantly from hemolysis ate $\mathrm{pH}_{7.4}$ (data not shown), which may serve as an indication that membrane interactions induced by the protonation of the polymer do not play a significant role in the endosomal escape.

\subsection{Conclusions}

Although $\mathrm{p}(\mathrm{CBA}-\mathrm{ABOL})$ has shown to be a very efficient vector for pDNA transfection, its use in siRNA delivery is limited due to the high polymer concentrations needed to form polyplexes. Polyplex formation with siRNA could be considerably promoted by incorporation of EDA or TETA units in the polymer chain. By synthesis of a series of poly(amido amine)s where EDA or TETA are copolymerized into p(CBA$\mathrm{ABOL}$ ) in different degrees, SS-PAA polymers with different degrees of cationic charge in the main chain could be obtained. It was demonstrated that incorporation of at least $20-30 \%$ EDA or TETA is necessary to form small and stable complexes with siRNA. For pDNA polyplexes, the inclusion of extra ethylene amino units in the $\mathrm{p}(\mathrm{CBA}-\mathrm{ABOL})$ polymer has an adverse effect on gene expression. However, for siRNA polyplexes outstanding gene silencing properties, comparable with Lipofectamine 2000, were obtained for polymers containing a low EDA content of only $20 \%$, making this polymer an excellent candidate for future development. Polymers containing higher EDA degrees or TETA turned all out to be too cytotoxic. This study indicates that the positive charge density in the gene carriers has to be delicately tuned to obtain maximum transfection results. In the two following chapters the most promising $\mathrm{p}(\mathrm{CBA}-\mathrm{ABOL} / \mathrm{EDA})$ copolymer will be further optimized as siRNA transfection reagent. 


\subsection{References}

I. Boussif, O., et al., A Versatile Vector for Gene and Oligonucleotide Transfer into Cells in Culture and in-Vivo - Polyethylenimine. Proceedings of the National Academy of Sciences of the United States of America, I995. 92(I6): p. 7297-7301.

2. Neu, M., D. Fischer, and T. Kissel, Recent advances in rational gene transfer vector design based on poly(ethylene imine) and its derivatives. Journal of Gene Medicine, 2005. 7(8): p. 992-I009.

3. van de Wetering, P., et al. 2-(dimethylamino)ethyl methacrylate based (co)polymers as gene transfer agents. I998: Elsevier Science Bv.

4. Howard, K.A., et al., RNA interference in vitro and in vivo using a chitosan/siRNA nanoparticle system. Molecular Therapy, 20o6. I4(4): p. 476484 .

5. Lin, C. and J.F.J. Engbersen, Effect of chemical functionalities in poly(amido amine)s for non-viral gene transfection. Journal of Controlled Release, 2008. I32(3): p. 267-272.

6. Richardson, S.C.W., et al., Poly(amidoamine)s as potential nonviral vectors: Ability to form interpolyelectrolyte complexes and to mediate transfection in vitro. Biomacromolecules, 2001. 2(3): p. 1023-1028.

7. Bielinska, A., et al., Regulation of in vitro gene expression using antisense oligonucleotides or antisense expression plasmids transfected using starburst PAMAM dendrimers. Nucleic Acids Research, I996. 24(II): p. 2176-2182.

8. Lin, C., et al., Bioreducible poly(amido amine)s with oligoamine side chains: Synthesis, characterization, and structural effects on gene delivery. Journal of Controlled Release, 2008. 126(2): p. I66-I74.

9. Lin, C., et al., Linear poly(amido amine)s with secondary and tertiary amino groups and variable amounts of disulfide linkages: Synthesis and in vitro gene transfer properties. Journal of Controlled Release, 2006. II6(2): p. I30-I37.

Io. Lin, C., et al., Novel Bioreducible Poly(amido amine)s for Highly Efficient Gene Delivery. Bioconjugate Chemistry, 2007. I8(I): p. I38-I45.

II. Mateos-Timoneda, M.A., et al., Poly(amido amine)s as Gene Delivery Vectors: Effects of Quaternary Nicotinamide Moieties in the Side Chains. ChemMedChem, 2007. 3: p. 478-486.

I2. Piest, M., et al., Novel poly(amido amine)s with bioreducible disulfide linkages in their diamino-units: Structure effects and in vitro gene transfer properties. Journal of Controlled Release, 2008. I30(I): p. 38-45.

I3. Oupicky, D., A.L. Parker, and L.W. Seymour, Laterally stabilized complexes of DNA with linear reducible polycations: Strategy for triggered intracellular activation of DNA delivery vectors. Journal of the American Chemical Society, 2002. I24(I): p. 8-9.

I4. Lv, H.T., et al., Toxicity of cationic lipids and cationic polymers in gene delivery. Journal of Controlled Release, 2006. II4(I): p. Ioo-Io9.

I5. Christensen, L.V., et al., Reducible poly(amido ethylenimine)s designed for triggered intracellular gene delivery. Bioconjugate Chemistry, 2006. I7(5): p. I233-I240. 
16. Meyer, M., et al., $A$ dimethylmaleic acid - melittin-polylysine conjugate with reduced toxicity, pH-triggered endosomolytic activity and enhanced gene transfer potential. Journal of Gene Medicine, 2007. 9(9): p. 797-805.

I7. Mather, B.D., et al., Michael addition reactions in macromolecular design for emerging technologies. Progress in Polymer Science, 2006. 3I(5): p. 487-53I.

I8. Grayson, A.C.R., A.M. Doody, and D. Putnam, Biophysical and structural characterization of polyethylenimine-mediated siRNA delivery in vitro. Pharmaceutical Research, 2006. 23(8): p. I868-1876.

I9. Wightman, L., et al., Different behavior of branched and linear polyethylenimine for gene delivery in vitro and in vivo. Journal of Gene Medicine, 200I. 3(4): p. 362-372.

20. Vader, P., et al., A method for quantifying cellular uptake of fluorescently labeled siRNA. Journal Of Controlled Release, 2010. I48(I): p. Io6-ıo9. 


\section{Chapter}

Optimizing the $p(C B A-A B O L / E D A)$ system as polymeric carrier for siRNA: fine-tuning of the charge density by small variations in the $A B O L / E D A$

ratio 


\begin{abstract}
For optimal performance of cationic polymers in gene silencing, the density of the charge on the polymer is of high importance. Both particle formation and cellular uptake as well as cytotoxicity greatly depend on the density of cationic charge present in the polymer. In this chapter we present a series of six $\mathrm{p}(\mathrm{CBA}-\mathrm{ABOL} / \mathrm{EDA})$ polymers, containing $5-30 \mathrm{~mol} \%$ of EDA. It was found that the optimal EDA content is between 20 and $30 \mathrm{~mol} \%$, since lower amounts of EDA resulted in lower silencing in HI299 cells, whereas higher EDA contents only increased cytotoxicity.
\end{abstract}

\title{
4.1 Introduction
}

In the previous chapter a disulfide-containing poly(amido amine) (SS-PAA) for siRNA was developed based on $N, N$-cystaminebisacrylamide (CBA), copolymerized with I-amino-4-butanol (ABOL) and ethylene diamine (EDA). It was found that especially $\mathrm{ABOL} / \mathrm{EDA}$ ratios of $100 / \mathrm{o}$ (i.e. $\mathrm{p}(\mathrm{CBA}-\mathrm{ABOL})$ ) and $80 / 20$ (i.e. $\mathrm{p}(\mathrm{CBA}-$ $\left.\mathrm{ABOL}_{80} / \mathrm{EDA}_{20}\right)$ ) resulted in polymers with very efficient knockdown values, with about only $30 \%$ remaining luciferase expression. Although an ABOL/EDA ratio of $80 / 20$ yielded the best knockdown at low polymer ratio's, this polymer becomes cytotoxic at high polymer concentrations. The 100/o ratio on the other hand did not show any cytotoxicity, but complexes formed from this polymer are poorly soluble in physiological solutions.

It was concluded that the extra positive charge introduced by the presence of $20 \%$ EDA monomers in the copolymers favorably contributed to the complex formation with siRNA, the particle stability and the silencing potential. However, a too high positive charge in the polymer ( $45 \%$ or more EDA) increased the cytotoxicity dramatically, resulting in even complete absence of silencing. This paradox between low efficiency for low charged systems on one hand and high cytotoxicity for high charge densities on the other hand is a frequently occurring problem in the development of novel transfection systems. Cationic charge is necessary for electrostatic interaction to form stable siRNA polyplexes and attraction to the negatively charged cell membrane, but at the same time, a high cationic charge is responsible for cytotoxicity of these particles by destabilizing cell membranes and intracellular vesicles [I]. Theoretically, each polymer will have an optimal charge density that is high enough to benefit in polyplex formation and cellular uptake, without being cytotoxic. Reineke and coworkers systematically investigated the effect of charge density in poly(glycoaminoamine)s by increasing the secondary amine number in the repeating unit [2-3]. An optimum of four to five secondary amines per repeating unit of $22-25$ atoms in length was found. A higher amount of amine groups did not further increase the transfection efficiency, but made

70 . Chapter 4 
the polymer more cytotoxic, whereas a lower amount of amine groups only decreased the fraction of transfected cells.

It is expected that for our ABOL/EDA copolymer also an optimum charge density exists, which will be determined by the relative amount of EDA in the copolymer. It is difficult to evaluate from the results in the previous chapter if the optimal EDA content is exactly at the $80 / 20 \mathrm{ABOL} / \mathrm{EDA}$ ratio, or that a somewhat higher or lower amount of EDA will turn out to be more optimal. In this chapter, the effects of charges in the $\mathrm{ABOL} / \mathrm{EDA}$ ratio will be further explored in a narrower range to find the optimum in ABOL/EDA composition, in which the polymeric carrier shows good silencing at low polymer/siRNA ratios with low tocixity and good solubility in physiological media.

\subsection{Materials and methods}

\subsubsection{Materials}

All chemicals and reference materials, 4-amino-I-butanol (ABOL, Merck), ethylene diamine (EDA, Sigma-Aldrich), N,N'cystaminebisacrylamide (CBA, Polysciences) and Lipofectamine 2000 (Invitrogen) were purchased in the highest purity and used without further purification. For culturing the Hi299 Fluct cells, RPMI I640 medium (Lonza) completed with 2\% (v/v) PennStrepp (Lonza), I\% (v/v) glutamine (Lonza) and I0\% (v/v) fetal bovine serum (Lonza) was used. Negative control siRNA was purchased from Qiagen, anti-luciferase siRNA was kindly supplied by the University of Utrecht. Luciferase assay reagent was obtained from Promega.

\subsubsection{Synthesis of $p$ (CBA-ABOL/EDA)}

The polymers were synthesized by Michael addition polymerization of 4-amino-Ibutanol (ABOL) and ethylene diamine (EDA) with $N, N^{\prime}$-cystaminebisacrylamide (CBA). Six different polymers were synthesized, having molar percent ratios between ABOL/EDA of 95/5, 90/10, 85/15, 80/20, 75/25 and 70/30 (Chapter 3, Scheme 3.I). Syntheses were carried out as reported before [4]. As a typical example, the synthesis of $\mathrm{p}\left(\mathrm{CBA}-\mathrm{ABOL}_{75} / \mathrm{EDA}_{25}\right)$ is described shortly. $700 \mathrm{mg}(2.69 \mathrm{mmol}) \mathrm{CBA}$ and $180 \mathrm{mg}(2.02$ $\mathrm{mmol}) \mathrm{ABOL}$ were dissolved in methanol/water $(4 / \mathrm{r} \mathrm{v} / \mathrm{v})$ and were allowed to react at $45^{\circ} \mathrm{C}$ in the dark in a nitrogen atmosphere. The reaction mixture became homogeneous within one hour. After six days of prepolymerization, $40.5 \mathrm{mg}$ ( $0.67 \mathrm{mmol}$ ) EDA was added and the reaction was proceeded for another two days. Then the polymerization was terminated by addition of a Io\% molar excess EDA, to consume remaining toxic 
acrylamide endgroups. After termination, the reaction mixture was diluted with hydrochloric acid (IM) and water, purified by ultrafiltration (MWCO гоoо, $\mathrm{pH}_{5}$ ) and recovered as its $\mathrm{HCl}$ salt by lyophilization. ${ }^{\mathrm{I}} \mathrm{H} \mathrm{NMR}\left(\mathrm{D}_{2} \mathrm{O}\right) \delta(\mathrm{ppm})=\mathrm{I} .58(\mathrm{~m}, 2 \mathrm{H}$, $\mathrm{CH}_{2} \mathrm{CH}_{2} \mathrm{NR}$ ); $\mathrm{I} .78$ (m, $\left.2 \mathrm{H}, \mathrm{CH}_{2} \mathrm{CH}_{2} \mathrm{OH}\right) ; 2.69$ (t, $\left.4 \mathrm{H}, \mathrm{NHCH} \mathrm{CH}_{2} \mathrm{NH}\right) ; 2.76$ (t, $2 \mathrm{H}$, $\left.\mathrm{CH}_{2} \mathrm{CONH}\right) ; 2.82$ (t, $\left.4 \mathrm{H}, \quad \mathrm{CH}_{2} \mathrm{SSCH}_{2}\right) ; \quad 3.2 \mathrm{I}\left(\mathrm{t}, \quad 2 \mathrm{H}, \mathrm{CH}_{2} \mathrm{CH}_{2} \mathrm{NR}\right) ; 3.32$ (t, $2 \mathrm{H}$, $\mathrm{COCH}_{2} \mathrm{CH}_{2} \mathrm{NH}$ ); 3.44 (t, $4 \mathrm{H}, \mathrm{CH}_{2} \mathrm{NRCH}$ ); $3.5 \mathrm{I}$ (t, $4 \mathrm{H}, \mathrm{NHCH} \mathrm{CH}_{2} \mathrm{SSCH}_{2} \mathrm{CH}_{2} \mathrm{NH}$ ); $3.6 \mathrm{I}$ (t, $\left.2 \mathrm{H}, \mathrm{CH}_{2} \mathrm{OH}\right)$

\subsubsection{Viscosimetry measurements}

Viscosity measurements were performed in an Ubbelohde micro viscosimeter in a thermostated bath at $25^{\circ} \mathrm{C}$. Polymers were dissolved in a sodium acetate buffer (Ioo $\mathrm{mM}, \mathrm{pH} 4.5$ ) at a concentration of $5 \mathrm{mg} / \mathrm{ml}$ at least 4 hours before viscosity measurements.

\subsubsection{GPC measurements}

Molecular weights were determined by GPC relative to PEG standards, using a PLGPC I20 from Polymer Labs using $300 \mathrm{mM}$ acetate buffer $\mathrm{pH} 4.5$ containing $30 \%(\mathrm{v} / \mathrm{v})$ methanol as eluent.

\subsubsection{Polyplex preparation}

Polyplexes at different polymer/siRNA mass ratios were prepared in HEPES buffered glucose (HBG: $20 \mathrm{mM}$ HEPES, $\mathrm{pH}$ 7.4, $5 \mathrm{wt} \%$ glucose). The polymer solution was added to the siRNA solution in a volume ratio of $4 / \mathrm{I}$, followed by $5 \mathrm{~s}$ vortexing and 30 min incubation at room temperature.

\subsubsection{In vitro gene silencing}

Knockdown efficiency was determined by silencing luciferase expression in $\mathrm{NCl}-$ Hı299 cells, stably expressing firefly luciferase. Knockdown and cell viability were evaluated in two parallel sessions, using anti-luciferase and non-coding siRNA, respectively. Cells were seeded in 96 well plates with a density of 8000 cells per well. After $24 \mathrm{~h}$ incubation at $37^{\circ} \mathrm{C}$ in a humidified atmosphere containing $5 \% \mathrm{CO}_{2}$, medium was replaced with Ioo $\mu$ fresh medium without FBS. Polyplexes containing $6.25 \mu \mathrm{g} / \mathrm{ml}$ siRNA at were prepared at five different polymer/siRNA mass ratios (3/I, 6/I, I2/I, 24/I and $48 / \mathrm{I})$ as described above. Lipofectamine 2000 was used as a reference and complexes were prepared according to the manufacturer's protocol. Polyplexes $(20 \mu \mathrm{l}$

72. Chapter 4 
per well) were added to the cells in quatro after I hour incubation with fresh medium, resulting in a final siRNA concentration of $66 \mathrm{nM}$. After 2 hours of transfection, polyplex medium was replaced by complete culture medium and the cells were incubated for another 48 hours. Cells were lysed in a freeze/thaw cycle and $50 \mu \mathrm{l}$ of the cell lysate was mixed with $50 \mu \mathrm{l}$ luciferase assay reagent containing the substrate luciferin. After Ioo - 220 seconds (in this timeframe the emitted light is constant - data not shown) the luciferase activity was determined by measuring the luminescence at $25^{\circ} \mathrm{C}$ for 4 seconds on a PerkinElmer 1420 Victor ${ }^{3}$ plate reader. Luciferase activity of untreated cells was defined as Ioo\% expression.

\subsection{Results and discussion}

\subsubsection{Synthesis and characterization of the $p(C B A-A B O L / E D A)$ polymers}

Six poly(amido amine) copolymers were synthesized by Michael-type addition polymerization from $N, N$-cystaminebisacrylamide (CBA), 4-amino-I-butanol and ethylene diamine (EDA) in different ABOL/EDA ratios (Chapter 3, Scheme 3.I). Every polymer was obtained as a white brittle material and the obtained ABOL/EDA molar percent ratio approximated the feed ratio within 5 mol percent deviation (Table 4.I). Based on previous results in the $\mathrm{p}(\mathrm{CBA}-\mathrm{ABOL} / \mathrm{EDA})$ synthesis, all polymers are supposed to be linear [4].

Table 4.1: Synthesis characteristics.

\begin{tabular}{ll}
\hline Feed composition $^{\mathbf{a}}$ & Obtained composition $^{\mathbf{b}}$ \\
\hline $95 / 5$ & $93 / 7^{*}$ \\
$90 / 10$ & $85 / 15^{*}$ \\
$85 / 15$ & $87 / 13$ \\
$80 / 20$ & $76 / 24^{*}$ \\
$75 / 25$ & $75 / 25$ \\
$70 / 30$ & $67 / 33^{*}$ \\
\hline
\end{tabular}

(a) Stoichiometrical feed ratio of $A B O L$ and EDA; (b) Determined by ${ }^{1} \mathrm{H} N M R$; Polymers marked with an ${ }^{*}$ were selected to be used for this study.

Since two polymers showed overlapping ABOL/EDA compositions, only four polymers were selected to continue the study (marked by an asterisk in Table 4.I). To get insight in the molecular weights of these polymers, their intrinsic viscosities were determined by Ubbelohde viscosimetry and molecular weights relative to PEG 
standards were determined by GPC. The intrinsic viscosities as well as the measured molecular weights are increasing for increased EDA contents of the polymers (Figure 4.I). It is important to interpret these results carefully, since both graphs might suggest an increasing molecular weight for increased EDA contents on the first sight. However, as we discuss in Appendix A of this thesis, an increased charge density in the polymer, and an increased rigidity of the polymer coil due the increasing amount of protonated EDA units with a high rotational barrier, lead to more expanded polymer coils, resulting in an increased viscosity of the polymer solution. Such behavior may also explain the increase in the calculated intrinsic viscosities. In the GPC measurements a similar increase in molecular weight was observed, and also here protonation behavior and the rigidity of the polymers play a key role. Increased polymer coil expansions also increase the hydrodynamic diameter of the polymer and this results in faster elution times in GPC as the effective path length becomes shorter. It was not further investigated whether the observed increase in elution times were indeed the result of the increased polymer charge density. However, the linearity with increased EDA contents in both intrinsic viscosities (Figure 4.Ia) and relative molecular weights (Figure 4.Ib) indicates that the molecular weights are rather similar. Moreover, it should be noted that the molecular weights plotted in Figure 4.I are relative to PEG standards. Absolute molecular weight values of these kind of polymers are expected to be around $30 \mathrm{~kg} / \mathrm{mol}$ as was determined in an absolute GPC measurement in Appendix A.
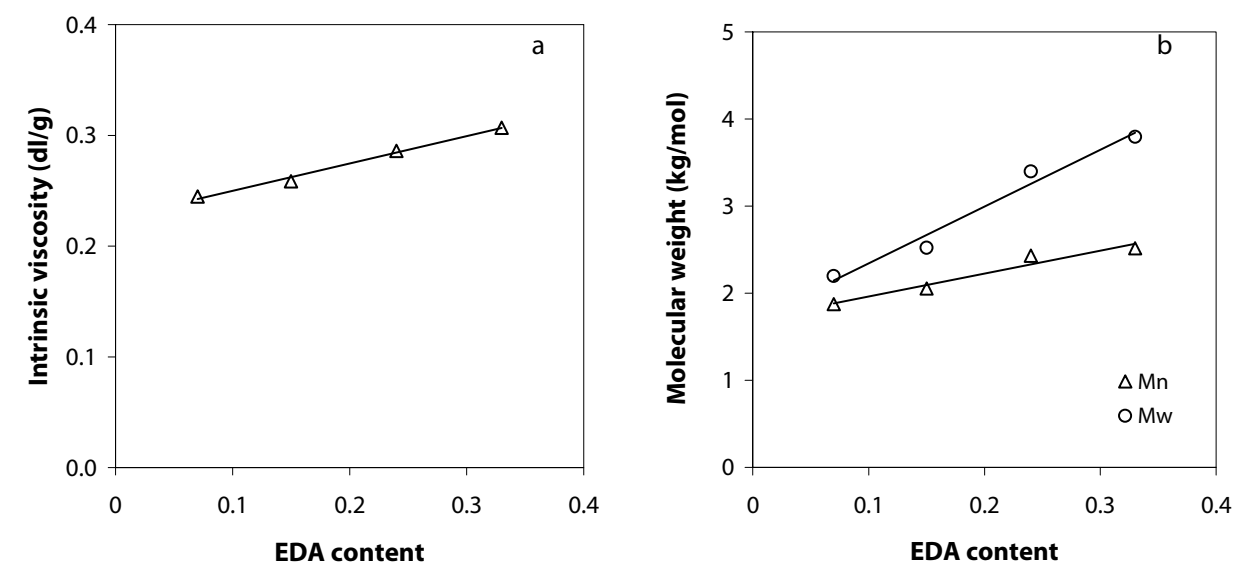

Figure 4.1: Intrinsic viscosities of the $p(C B A-A B O L / E D A)$ polymers determined by Ubbelohde viscosimetry (a) and molecular weights relative to PEG standards determined by GPC (b). 


\subsubsection{In vitro gene silencing}

The silencing potential of the $\mathrm{p}(\mathrm{CBA}-\mathrm{ABOL} / \mathrm{EDA})$ polymers was evaluated by determination of the knockdown of luciferase expression in Hi299 cells that stably express this enzyme. The luciferase expression of the lysed cells 48 hours after transfection was measured by the luminescent oxidation of luciferin to oxyluciferin and was used as a measure for gene silencing. In Figure 4.2, the residual luciferase expressions are shown.
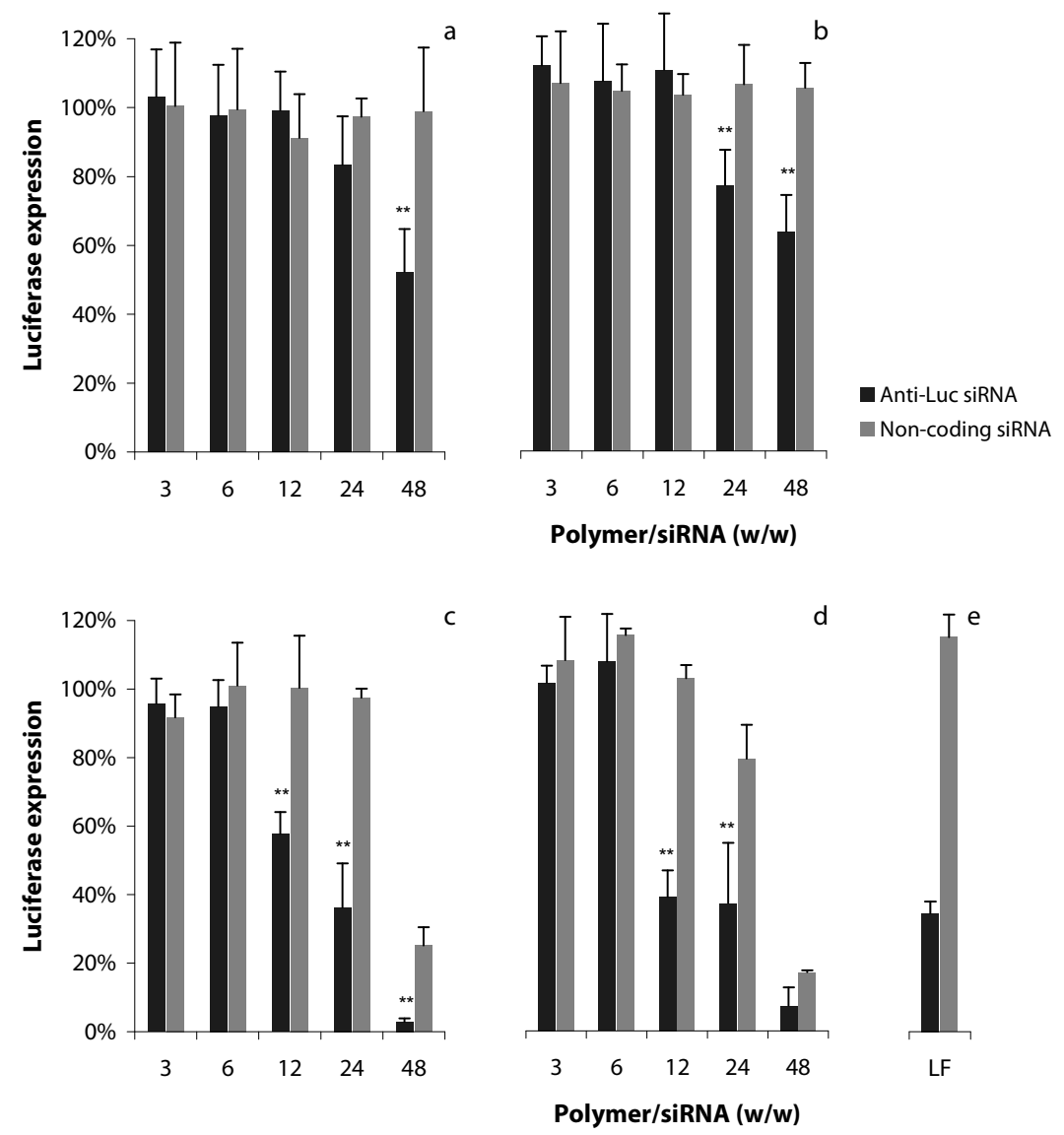

Figure 4.2: Luciferase expression of $\mathrm{H} 1299$ Fluct cells 48 hours after transfection with anti-luciferase siRNA (black) and non-coding control siRNA (grey) with $\mathrm{p}(\mathrm{CBA}-\mathrm{ABOL} / \mathrm{EDA}$ ) in the molar ABOL/EDA ratio of 93/7 (a), $85 / 15$ (b), 76/24 (c) and 67/33 (d). Lipofectamine 2000 (LF) was used as reference transfection agent (e). Each bar value represents the mean $\pm S D$ of $n=3$ or 4 . For statistical analysis of differences between anti-luciferase and non-coding siRNA an unpaired Student's t-test was used $\left({ }^{*} p<0.05 ;{ }^{* *} p<0.01\right)$.

It was demonstrated that the luciferase expressions are silenced more efficiently by polymers containing a higher EDA content which is most evident for the I2/I and 24/I polymer/siRNA weight ratios. Polymers with ABOL/EDA ratios of $76 / 24$ and $67 / 33$ show silencing efficiencies comparable to Lipofectamine 2000, which is currently the 
standard for in vitro siRNA delivery. In accordance with previous results as presented in chapter 3 it was observed that the cytotoxicity increases with increased EDA content of the polymers. This is indicated by the lower luciferase expressions of cells treated with a control siRNA in polyplexes from $\mathrm{p}\left(\mathrm{CBA}-\mathrm{ABOL}_{76} / \mathrm{EDA}_{24}\right)$ and $\mathrm{p}\left(\mathrm{CBA}-\mathrm{ABOL}_{67} / \mathrm{EDA}_{33}\right)$ in a 48/I polymer/siRNA weight ratio. Considering the silencing and cytotoxicity profiles that are observed with these polymers and taking into account the unfavorable cytotoxicity profiles of $\mathrm{p}(\mathrm{CBA}-\mathrm{ABOL} / \mathrm{EDA})$ copolymers with higher EDA contents (chapter 3), it is concluded that the optimal EDA content in these polymers is between 20 and $30 \mathrm{~mol} \%$. Polyplexes of those polymers have shown high gene silencing together with negligible cytotoxicity at their optimal I2/I and 24/I polymer/siRNA weight ratios (Figure $4.2 \mathrm{c}$ and $\mathrm{d}$ ).

\subsection{Conclusions}

A series of six p(CBA-ABOL/EDA) copolymers containing 5 - 30 mol\% of EDA as the amino monomer was synthesized. It was found that the optimal ABOL/EDA ratio for best gene knockdown in Hi299 cells is between 20 and $30 \mathrm{~mol} \%$, since lower amounts of EDA resulted in lower silencing, whereas higher EDA contents only increased cytotoxicity. Therefore it is decided to continue the work in this thesis with polymers containing $25 \mathrm{~mol} \%$ of EDA.

\subsection{References}

I. Fischer, D., et al., In vitro cytotoxicity testing of polycations: influence of polymer structure on cell viability and hemolysis. Biomaterials, 2003. 24(7): p. II2I-II3I.

2. Liu, Y.M. and T.M. Reineke, Poly(glycoamidoamine)s for gene delivery. Structural effects on cellular internalization, buffering capacity, and gene expression. Bioconjugate Chemistry, 2007. I8(I): p. 19-30.

3. Lee, C.C., Y. Liu, and T.M. Reineke, General structure-activity relationship for poly(glycoamidoamine)s: The effect of amine density on cytotoxicity and DNA delivery efficiency. Bioconjugate Chemistry, 2008. 19(2): p. 428-440.

4. van der Aa, L.J., et al., Optimization of poly(amido amine)s as vectors for siRNA delivery. Journal Of Controlled Release, 20II. I50(2): p. I77-I86. 


\title{
Chapter
}

\author{
Optimizing the $p(C B A-A B O L / E D A)$ \\ system as polymeric carrier for siRNA: \\ tuning hydrophobicity by changing \\ the alcoholic sidegroup
}

\author{
L.J.van $\operatorname{der} \mathrm{Aa}$ \\ P. Vader \\ R.M. Schiffelers \\ J.F.J. Engbersen
}




\begin{abstract}
Hydrophobic properties of polymeric gene vectors can positively contribute to their transfection efficiency. The alkyl chain length of $\omega$-hydroxyalkyl side chains in disulfide-based poly(amido amine)s (SS-PAA) was investigated to tune these hydrophobic properties. Therefore, N,N-cystaminebisacrylamide (CBA) was copolymerized in a Michael addition polymerization with ethylene diamine (EDA) and five different $\alpha, \omega$-amino alcohols having an increased alkyl chain length. It was aimed to optimize gene silencing by finding an optimal balance in hydrophilicity and lipophilicity. It was found that the chain length does not significantly affect particle formation and gene knockdown, but has profound influence on the cytotoxicity and hemolysis of the polymer. The existing hydroxybutyl-containing polymer $\mathrm{p}(\mathrm{CBA}$ ABOL/EDA) appeared to be best candidate, since it showed excellent gene silencing properties and negligible cytotoxicity.
\end{abstract}

\title{
5.1 Introduction
}

In the previous chapters (Chapter 3 and 4) we developed a new disulfide-based poly(amido amine) (SS-PAA) carrier for siRNA delivery [I]. This polymer was prepared by Michael-type polymerization of 4-amino-I-butanol (ABOL) and ethylene diamine (EDA) to $N, N$-cystaminebisacrylamide (CBA). ABOL was introduced in the polymer since the butanolic side chains establish a good interaction with cell membranes and EDA was introduced because the diaminoethyl units enhance the cationic charge density in the main chain, thereby increasing the electrostatic interaction between polymer and siRNA molecules. It was found that the optimal molar ratio between ABOL and EDA was $75 / 25$, effectuating gene silencing of more than $70 \%$ without significant cytotoxicity. Higher ABOL content abated the complex stability and only showed knockdown when a large excess of polymer was applied in the polyplex solution. A higher EDA content in the polymer on the other hand did not further contribute to the complex stability, but eliminated the impressive silencing properties and gives a dramatical increase of the cytotoxicity. p(CBA-ABOL/EDA) furthermore contains disulfides in the main chain, delivered by the CBA units, and these disulfides ensure rapid intracellular degradation of the polymer, thereby facilitating efficient unpacking of therapeutic siRNA.

Although the polymer $\mathrm{p}\left(\mathrm{CBA}-\mathrm{ABOL}_{75} / \mathrm{EDA}_{25}\right)$ is already a commendable carrier for siRNA, it was thought that there was still room for further improvement in terms of gene silencing. It is expected that the hydrophobicity/hydrophilicity balance of poly(amido amine)s also plays a role in their gene silencing efficiency. It is generally accepted that increasing the hydrophobicity of a carrier can positively contribute to the

78 - Chapter 5 
transfection properties [2]. Kim et al. showed that hydrophobic modification of their aminoethyl poly(aspartamide) carrier with stearic acid resulted in siRNA complex stabilization and subsequently in improved cellular uptake [3]. Fatty acid modification of PEI by introducing stearic or oleic moieties was studied by Alshamsan et al [4] and they found that the increased hydrophobicity facilitated a better complexation and protection of siRNA against serum nucleases. Enhanced plasma membrane interactions due to these hydrophobic effects finally resulted in a better knockdown. Aravindan et al. showed that hydrophobic PEI modification using the smaller acyl and propionyl functionalities improved transfection as well by enhanced membrane interactions [5]. Finally, cholesteryl moieties to increase hydrophobicity of an oligoarginine carrier were prepared by Kim et al. and demonstrated enhanced cellular uptake and increased transfection efficiency [6].

On the other hand, several researchers discovered that there is an optimum between hydrophilicity and lipophilicity and that raising the hydrophobicity too much results in lowering of transfection efficiency and increased cytotoxicity. This was demonstrated by Philipp et al., who modified oligo ethylene imines with alkyl acrylates [7]. Where siRNA encapsulation was improved by elongation of the alkyl chain from ethyl to lauryl, gene silencing was only found for the hexyl-modified polymers and increased cytotoxicity was found with increasing alkyl chain lengths. Similar results were published by Dehshahri et al., who modified branched PEI with polyamines, using alkyl spacers of different lengths. Optimal gene expression was found for the hexanoic spacer; the longer decanoic and hexadecanoic spacers showed hardly any gene expression, although cytotoxicity was not observed [8]. Thomas found that branched PEI functionalized with dodecyl iodide strongly declined the transfection efficiency and that functionalization with hexadecyl even completely impeded transfection [9].

Previous work of our group on plasmid delivery showed that SS-PAA homopolymers with pentanol side chains gave higher gene expression than those with butanol side chains. However, due to a lower solubility, the pentanol derivatives were more difficult to handle than the butanol analogs [io]. Anderson et al. also found a similar pattern for poly( $\beta$-amino ester)s [II]. However, solubility problems play a less important role in polymers containing diaminoethyl units, since the (protonated) extra amine groups in the main chain do not only provide extra nucleotide interaction, but also improved water solubility. This enabled us to study the effects of hydrophobicity by variation of the length of the alcoholic side group on the gene vector properties. In this study we prepared five SS-PAAs differing in alcohol side chain length (Scheme 5.I) and studied their effect on polyplex formation, gene silencing efficiency, cytotoxicity and hemolytic activity. 

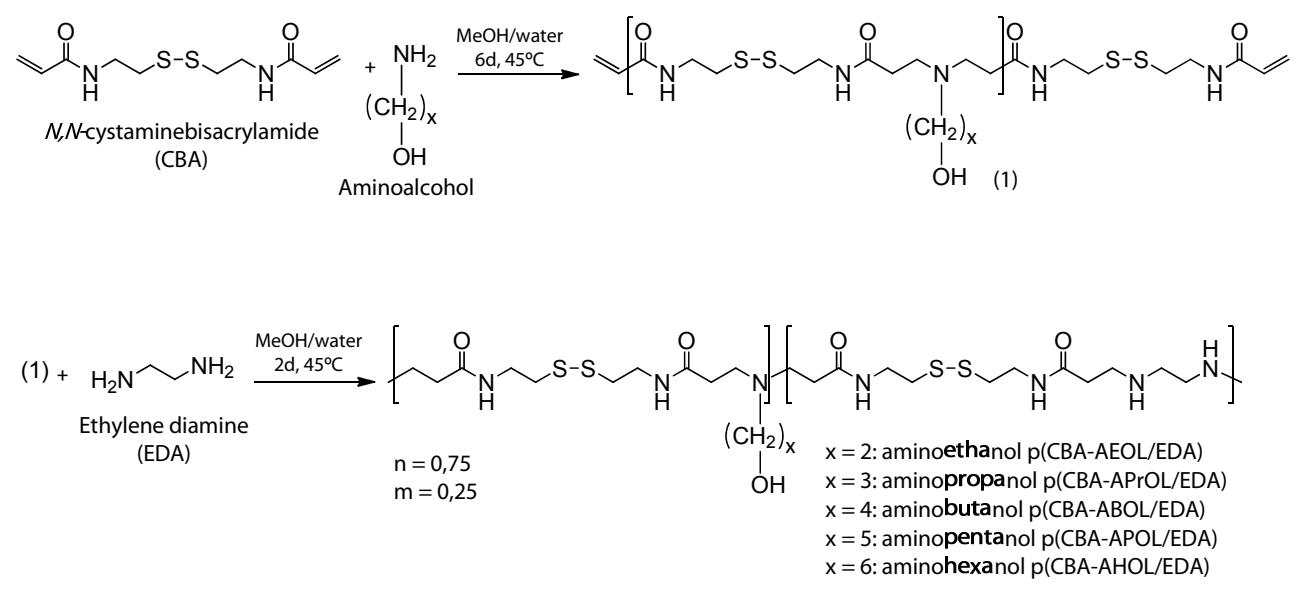

Scheme 5.1: Synthesis of the SS-PAA copolymers with five different alcohols side chain lengths.

\subsection{Materials and methods}

\subsubsection{Materials}

All chemicals and reference materials, 2-amino-I-ethanol (AEOL, Aldrich), 3amino-I-propanol (APrOL, Aldrich), 4-amino-I-butanol (ABOL, Merck), 5-amino-Ipentanol (APOL, Merck), 6-amino-I-hexanol (AHOL, Fluka), ethylene diamine (EDA, Aldrich), N,N'-cystaminebisacrylamide (CBA, Polysciences), sodium 3'-[I-phenylaminocarbonyl]-3,4-tetrazolium]-bis[4-methoxy-6-nitro]benzenesulfonic acid hydrate (XTT, Polysciences), branched poly(ethylene imine) (25 kg/mol, Aldrich) and Lipofectamine 2000 (Invitrogen) were purchased in the highest purity and used without further purification. For culturing the Hı299 Fluct cells RPMI I640 medium (Lonza) completed with $2 \%(v / v)$ PennStrepp (Lonza), I\% (v/v) glutamine (Lonza) and Io\% (v/v) fetal bovine serum (Lonza) was used. Negative control siRNA was purchased from Qiagen, antiluciferase siRNA was kindly supplied by the University of Utrecht. Luciferase assay reagent was obtained from Promega.

\subsubsection{Synthesis of $p(C B A-A E O L / E D A)$}

The polymer was synthesized by Michael addition polymerization of 2-amino-Iethanol (AEOL) and ethylene diamine (EDA) with $N, N$ '-cystaminebisacrylamide (CBA) as reported before [I]. The general synthesis scheme is shown in Scheme 5.I. Shortly, $700 \mathrm{mg}(2.69 \mathrm{mmol}) \mathrm{CBA}$ and $\mathrm{I} 25 \mathrm{mg}(2.02 \mathrm{mmol})$ AEOL were dissolved in methanol / water $(4 / \mathrm{I} \mathrm{v} / \mathrm{v})$ and were allowed to react at $45^{\circ} \mathrm{C}$ in the dark in a nitrogen atmosphere.

$80 \cdot$ Chapter 5 
The reaction mixture became homogeneous within one hour due to formation of oligomers. After six days of prepolymerization, $40.5 \mathrm{mg}$ ( $0.67 \mathrm{mmol}$ ) EDA was added and the reaction was proceeded for another two days. Then the polymerization was terminated by addition of a I0\% molar excess of EDA, to consume remaining toxic acrylamide endgroups. After termination, the reaction mixture was diluted with hydrochloric acid (IM) and water, purified by ultrafiltration (MWCO гоoо, $\mathrm{pH}_{5}$ ) and recovered as its $\mathrm{HCl}$ salt by lyophilization. Yield: $22 \mathrm{I} \mathrm{mg}(25 \%)$; [n]: $0,44 \mathrm{dl} / \mathrm{g}$; ${ }^{1} \mathrm{H} \mathrm{NMR}$ $\left(\mathrm{D}_{2} \mathrm{O}\right) \delta(\mathrm{ppm})=2.7 \mathrm{I}\left(\mathrm{t}, 4 \mathrm{H}, \mathrm{NH} \boldsymbol{C H}_{2} \mathrm{CH}_{2} \mathrm{NH}\right) ; 2.79\left(\mathrm{t}, 2 \mathrm{H}, \mathrm{CH}_{2} \mathrm{CONH}\right) ; 2.83\left(\mathrm{t},{ }_{4} \mathrm{H}\right.$, $\mathrm{CH}_{2} \mathrm{SSCH}$ ); 3.35 (t, $\left.2 \mathrm{H}, \mathrm{NCH}_{2} \mathrm{CH}_{2} \mathrm{OH}\right) ; 3.39$ (t, $\left.2 \mathrm{H}, \mathrm{COCH}_{2} \mathrm{CH}_{2} \mathrm{NH}\right) ; 3.50$ (t, $4 \mathrm{H}$, $\left.\mathrm{CH}_{2} \mathrm{NRCH} \mathrm{CH}_{2}\right) ; 3.50\left(\mathrm{t}, 4 \mathrm{H}, \mathrm{NHCH} \mathrm{CH}_{2} \mathrm{SSCH}_{2} \mathrm{CH}_{2} \mathrm{NH}\right) ; 3.90\left(\mathrm{t}, 2 \mathrm{H}, \mathrm{CH}_{2} \mathrm{OH}\right)$.

\subsubsection{Synthesis of $p$ (CBA-APrOL/EDA)}

$\mathrm{p}$ (CBA-APrOL/EDA) was synthesized from $700 \mathrm{mg}(2.69 \mathrm{mmol}) \mathrm{CBA}$ and $152 \mathrm{mg}$ (2.02 mmol) APrOL under the same conditions as described for $\mathrm{p}(\mathrm{CBA}-\mathrm{AEOL} / \mathrm{EDA})$, employing APrOL instead of AEOL. Yield: $129 \mathrm{mg}(\mathrm{I} 4 \%)$; [n]: o,45 dl/g; ' $\mathrm{H}$ NMR $\left(\mathrm{D}_{2} \mathrm{O}\right) \delta$ $(\mathrm{ppm})=\mathrm{I} .96\left(\mathrm{~m}, 2 \mathrm{H}, \mathrm{CH}_{2} \mathrm{CH}_{2} \mathrm{OH}\right) ; 2.7 \mathrm{I}\left(\mathrm{t}, 4 \mathrm{H}, \mathrm{NHCH} \mathrm{CH}_{2} \mathrm{NH}\right) ; 2.77(\mathrm{t}, 2 \mathrm{H}$, $\left.\mathrm{CH}_{2} \mathrm{CONH}\right) ; 2.82$ (t, $4 \mathrm{H}, \quad \mathrm{CH}_{2} \mathrm{SSCH}$ ); 3.30 (t, $\left.2 \mathrm{H}, \mathrm{CH}_{2} \mathrm{CH}_{2} \mathrm{NR}\right) ; 3.35$ (t, $2 \mathrm{H}$, $\mathrm{COCH}_{2} \mathrm{CH}_{2} \mathrm{NH}$ ); 3.45 (t, $4 \mathrm{H}, \mathrm{CH}_{2} \mathrm{NRCH} \mathrm{CH}_{2}$; $3.5 \mathrm{O}$ (t, $4 \mathrm{H}, \mathrm{NH} \mathrm{CH}_{2} \mathrm{CH}_{2} \mathrm{SSCH}_{2} \mathrm{CH}_{2} \mathrm{NH}$ ); 3.68 (t, $\left.2 \mathrm{H}, \mathrm{CH}_{2} \mathrm{OH}\right)$.

\subsubsection{Synthesis of $p$ (CBA-ABOL/EDA)}

$\mathrm{p}$ (CBA-ABOL/EDA) was synthesized from $700 \mathrm{mg}(2.69 \mathrm{mmol}) \mathrm{CBA}$ and $\mathrm{I} 80 \mathrm{mg}$ (2.02 mmol) ABOL under the same conditions as described for p(CBA-AEOL/EDA), employing ABOL instead of AEOL. Yield: $466 \mathrm{mg}(50 \%) ;[\mathrm{n}]$ : o,36 dl/g; ${ }^{\mathrm{H}} \mathrm{H} \mathrm{NMR}\left(\mathrm{D}_{2} \mathrm{O}\right) \delta$ $(\mathrm{ppm})=1.58\left(\mathrm{~m}, \quad 2 \mathrm{H}, \quad \mathrm{CH}_{2} \mathrm{CH}_{2} \mathrm{NR}\right) ; \quad \mathrm{I} .78\left(\mathrm{~m}, \quad 2 \mathrm{H}, \mathrm{CH}_{2} \mathrm{CH}_{2} \mathrm{OH}\right) ; 2.69$ (t, $4 \mathrm{H}$, $\left.\mathrm{NHCH} \mathrm{CH}_{2} \mathrm{NH}\right) ; 2.76$ (t, $\left.2 \mathrm{H}, \mathrm{CH}_{2} \mathrm{CONH}\right) ; 2.82\left(\mathrm{t}, 4 \mathrm{H}, \mathrm{CH}_{2} \mathrm{SSCH}\right) ; 3.2 \mathrm{I}(\mathrm{t}, 2 \mathrm{H}$, $\mathrm{CH}_{2} \mathrm{CH}_{2} \mathrm{NR}$ ); 3.32 (t, $\left.2 \mathrm{H}, \mathrm{COCH}_{2} \mathrm{CH}_{2} \mathrm{NH}\right) ; 3.44$ (t, $4 \mathrm{H}, \mathrm{CH}_{2} \mathrm{NRCH}$ ); $3.5 \mathrm{I}$ (t, $4 \mathrm{H}$, $\left.\mathrm{NHCH} \mathrm{CH}_{2} \mathrm{SSCH}_{2} \mathrm{CH}_{2} \mathrm{NH}\right)$; 3.6I (t, $\left.2 \mathrm{H}, \mathrm{CH}_{2} \mathrm{OH}\right)$.

\subsubsection{Synthesis of $p(C B A-A P O L / E D A)$}

$\mathrm{p}$ (CBA-APOL/EDA) was synthesized from $700 \mathrm{mg}(2.69 \mathrm{mmol}) \mathrm{CBA}$ and $208 \mathrm{mg}$ (2.02 mmol) APOL under the same conditions as described for $\mathrm{p}(\mathrm{CBA}-\mathrm{AEOL} / \mathrm{EDA})$, employing APOL instead of AEOL. Yield: $535 \mathrm{mg}(56 \%) ;[\mathrm{n}]: 0,35 \mathrm{dl} / \mathrm{g}$; ${ }^{\mathrm{H}} \mathrm{H} \mathrm{NMR}\left(\mathrm{D}_{2} \mathrm{O}\right) \delta$ $(\mathrm{ppm})=\mathrm{I} .38\left(\mathrm{~m}, 2 \mathrm{H}, \boldsymbol{C H}_{2} \mathrm{CH}_{2} \mathrm{CH}_{2} \mathrm{OH}\right) ; \mathrm{I} .55\left(\mathrm{~m}, 2 \mathrm{H}, \boldsymbol{C H}_{2} \mathrm{CH}_{2} \mathrm{NR}\right) ; \mathrm{I} .74(\mathrm{~m}, 2 \mathrm{H}$, $\left.\mathrm{CH}_{2} \mathrm{CH}_{2} \mathrm{OH}\right) ; 2.70\left(\mathrm{t}, 4 \mathrm{H}, \mathrm{NH} \mathrm{CH}_{2} \mathrm{CH}_{2} \mathrm{NH}\right) ; 2.76\left(\mathrm{t}, 2 \mathrm{H}, \mathrm{CH}_{2} \mathrm{CONH}\right) ; 2.82(\mathrm{t}, 4 \mathrm{H}$, 
$\mathrm{CH}_{2} \mathrm{SSCH}_{2}$ ); 3.19 (t, $\left.2 \mathrm{H}, \mathrm{CH}_{2} \mathrm{CH}_{2} \mathrm{NR}\right) ; 3.35$ (t, $\left.2 \mathrm{H}, \mathrm{COCH}_{2} \mathrm{CH}_{2} \mathrm{NH}\right) ; 3.43$ (t, $4 \mathrm{H}$, $\left.\mathrm{CH}_{2} \mathrm{NRCH} \mathrm{CH}_{2}\right) ; 3.5 \mathrm{O}\left(\mathrm{t}, 4 \mathrm{H}, \mathrm{NH} \mathrm{CH}_{2} \mathrm{CH}_{2} \mathrm{SSCH}_{2} \mathrm{CH}_{2} \mathrm{NH}\right) ; 3.56\left(\mathrm{t}, 2 \mathrm{H}, \mathrm{CH}_{2} \mathrm{OH}\right)$.

\subsubsection{Synthesis of $p$ (CBA-AHOL/EDA)}

$\mathrm{p}(\mathrm{CBA}-\mathrm{AHOL} / \mathrm{EDA})$ was synthesized from $700 \mathrm{mg}(2.69 \mathrm{mmol}) \mathrm{CBA}$ and $236 \mathrm{mg}$ (2.02 mmol) AHOL under the same conditions as described for $\mathrm{p}(\mathrm{CBA}-\mathrm{AEOL} / \mathrm{EDA})$, employing AHOL instead of AEOL. Yield: 70I mg (70\%); [n]: o,47 dl/g; ${ }^{\mathrm{r}} \mathrm{H} \mathrm{NMR}\left(\mathrm{D}_{2} \mathrm{O}\right) \delta$ $(\mathrm{ppm})=\mathrm{I} .35\left(\mathrm{~m}, 4 \mathrm{H}, \boldsymbol{C H}_{2} \mathrm{CH}_{2} \mathrm{CH}_{2} \mathrm{CH}_{2} \mathrm{OH}\right) ; \mathrm{I} .52\left(\mathrm{~m}, 2 \mathrm{H}, \boldsymbol{C H}_{2} \mathrm{CH}_{2} \mathrm{NR}\right) ; \mathrm{I} .73(\mathrm{~m}, 2 \mathrm{H}$, $\left.\mathrm{CH}_{2} \mathrm{CH}_{2} \mathrm{OH}\right) ; 2.7 \mathrm{I}\left(\mathrm{t}, 4 \mathrm{H}, \mathrm{NH} \mathrm{CH}_{2} \mathrm{CH}_{2} \mathrm{NH}\right) ; 2.76\left(\mathrm{t}, 2 \mathrm{H}, \mathrm{CH}_{2} \mathrm{CONH}\right) ; 2.83(\mathrm{t}, 4 \mathrm{H}$, $\left.\mathrm{CH}_{2} \mathrm{SSCH} \mathrm{CH}_{2}\right) ; 3.18\left(\mathrm{t}, 2 \mathrm{H}, \mathrm{CH}_{2} \mathrm{CH}_{2} \mathrm{NR}\right) ; 3.35\left(\mathrm{t}, 2 \mathrm{H}, \mathrm{COCH}_{2} \mathrm{CH}_{2} \mathrm{NH}\right) ; 3.43(\mathrm{t}, 4 \mathrm{H}$, $\left.\mathrm{CH}_{2} \mathrm{NRCH}_{2}\right) ; 3.5 \mathrm{O}\left(\mathrm{t}, 4 \mathrm{H}, \mathrm{NH} \mathrm{CH}_{2} \mathrm{CH}_{2} \mathrm{SSCH}_{2} \mathrm{CH}_{2} \mathrm{NH}\right) ; 3.55\left(\mathrm{t}, 2 \mathrm{H}, \mathrm{CH}_{2} \mathrm{OH}\right)$

\subsubsection{Viscosimetry measurements}

Viscosity measurements were performed in an Ubbelohde micro viscosimeter in a thermostated bath at $25^{\circ} \mathrm{C}$. The polymers were lyophilized once again before preparing the polymer solutions, to guarantee that hygroscopic moisture attraction did not influence the concentration. Polymers were dissolved in a sodium acetate buffer (Ioo $\mathrm{mM}, \mathrm{pH} 4.5$ ) at a concentration of $5 \mathrm{mg} / \mathrm{ml}$ at least 4 hours before viscosity measurements.

\subsubsection{Buffer capacity}

The buffer capacity was determined by an acid-base titration. All polymers were dissolved with a concentration of $\mathrm{I} .5 \mathrm{mM}$ of protonable nitrogens in $150 \mathrm{mM} \mathrm{NaCl}$. Io $\mathrm{ml}$ of these solutions were taken out and the $\mathrm{pH}$ was adjusted to 3.0 using $0.5 \mathrm{M} \mathrm{HCl}$. Subsequently, this solution was titrated with o.or $\mathrm{M} \mathrm{NaOH}$ to $\mathrm{pH}$ io using an automated titrator (Metrohm 702 SM Titrino). As a reference, the same procedure was applied to branched PEI $(25 \mathrm{~kg} / \mathrm{mol})$ and $150 \mathrm{mM} \mathrm{NaCl}$ solutions. The buffer capacity is defined as the percentage of nitrogen becoming deprotonated from $\mathrm{pH}$ 5.I to $\mathrm{pH} 7.4$ and can be calculated from (I):

$$
\text { Buffer capacity }=\frac{c_{\mathrm{NaOH}}\left(\Delta V_{\mathrm{p}}-\Delta V_{\mathrm{NaCl}}\right)}{n} \times 100 \%
$$

Where $\Delta V_{p}$ and $\Delta V_{N a C l}$ are the volumes of $\mathrm{NaOH}$ solution added between pH 5.I and 7.4 to the polymer solution and a blank $\mathrm{NaCl}$ solution, respectively, and $n$ is total amount of protonable nitrogens present in the polymer solution.

82 - Chapter 5 


\subsubsection{Polymer aggregation behavior}

All polymers were dissolved with a concentration of $\mathrm{I} .5 \mathrm{mM}$ of protonable nitrogens in a $20 \mathrm{mM}$ phosphate buffer $\mathrm{pH} 7.2$ supplemented with $130 \mathrm{mM} \mathrm{NaCl}$. The count rates during dynamic light scattering size measurements were used as an indicator for the aggregation behavior of the polymer.

\subsubsection{Polyplex preparation}

Polyplexes at different polymer/siRNA mass ratios were prepared in HEPES buffered glucose (HBG: $20 \mathrm{mM}$ HEPES, $\mathrm{pH}$ 7.4, $5 \mathrm{wt} \%$ glucose). The polymer solution was added to the siRNA solution in a volume ratio of $4 / \mathrm{I}$, followed by $5 \mathrm{~s}$ vortexing and 30 min incubation at room temperature.

\subsubsection{Polyplex properties}

Polyplexes containing $6.25 \mu \mathrm{g} / \mathrm{ml}$ siRNA were prepared at four different polymer/siRNA mass ratios (3/I, 6/I, I2/I, 24/I) as described above. The hydrodynamic diameter and the $\zeta$-potential were measured by dynamic light scattering on a Zetasizer Nano ZS (Malvern Instruments) at $25^{\circ} \mathrm{C}$.

\subsubsection{Gel retardation}

Polyplexes containing $40 \mu \mathrm{g} / \mathrm{ml}$ siRNA were prepared as described above at seven different polymer/siRNA mass ratios (0.75/I, I.5/I, 3/I, 6/I, I2/I, 24/I, 48/I). To test polymer degradation by disulfide reduction, glutathione (GSH) was added 30 min after polyplex formation to obtain a final GSH concentration of $15 \mathrm{mM}$. After another 30 minutes (with or without GSH incubation), $15 \mu \mathrm{l}$ of polyplex solution was mixed with 3 $\mu \mathrm{l}$ of loading buffer and loaded on a $4.0 \mathrm{wt} \%$ agarose gel containing I.25 $\mu \mathrm{M}$ ethidium bromide. Electrophoresis was performed for $60 \mathrm{~min}$ at $90 \mathrm{~V}$ in a TAE running buffer (40 $\mathrm{mM}$ tris(hydroxymethyl)aminomethane, $20 \mathrm{mM}$ acetic acid, io mM EDTA, pH 8,o) supplemented with I.25 $\mu \mathrm{M}$ ethidium bromide. After electrophoresis, pictures were taken on a Biorad Gel Doc 2000 under UV illumination and analyzed using Biorad Multi Analyst software version I.I.

\subsubsection{In vitro gene silencing}

Knockdown efficiency was determined by silencing luciferase expression in $\mathrm{NCl}$ Hi299 cells, stably expressing firefly luciferase. Knockdown and cell viability were evaluated in two parallel sessions, using anti-luciferase and non-coding siRNA, 
respectively. Cells were seeded in 96 well plates with a density of 8000 cells per well. After $24 \mathrm{~h}$ incubation at $37^{\circ} \mathrm{C}$ in a humidified atmosphere containing $5 \% \mathrm{CO}_{2}$, medium was replaced with Ioo $\mu$ fresh medium without FBS. Polyplexes containing $6.25 \mu \mathrm{g} / \mathrm{ml}$ siRNA were prepared at four different polymer/siRNA mass ratios (3/I, 6/I, I2/I, 24/I) as described above. Lipofectamine 2000 was used as a reference and complexes were prepared according to the manufacturer's protocol. Polyplexes (2o $\mu \mathrm{l}$ per well) were added to the cells in quatro after I hour incubation with fresh medium, resulting in a final siRNA concentration of $66 \mathrm{nM}$. After 2 hours of transfection, polyplex medium was replaced by complete culture medium and the cells were incubated for another 48 hours. Cells were lysed in a freeze/thaw cycle and $50 \mu \mathrm{l}$ of the cell lysate was mixed with $50 \mu \mathrm{l}$ luciferase assay reagent containing the substrate luciferin. After Ioo - 220 seconds (in this timeframe the emitted light is constant - data not shown) the luciferase activity was determined by measuring the luminescence at $25^{\circ} \mathrm{C}$ for 4 seconds on a PerkinElmer I420 Victor ${ }^{3}$ plate reader. Luciferase activity of untreated cells was defined as I00\% expression.

\subsubsection{Cytotoxicity}

The cytotoxicity of the polymers was evaluated on NCl-Hi299 cells. The cells were seeded in 96 well plates with a density of 8000 cells per well. After $24 \mathrm{~h}$ incubation at $37^{\circ} \mathrm{C}$ in a humidified atmosphere containing $5 \% \mathrm{CO}_{2}$, medium was replaced with Ioopl fresh medium without FBS. Polymers were dissolved in HBG (20 mM HEPES, pH 7.4, 5 wt\% glucose) at $4.8 \mathrm{mg} / \mathrm{ml}$ and diluted I:I nine times. Polymer dilutions (20 $\mu \mathrm{l}$ per well) were added to the cells in quatro after I hour incubation with fresh medium, resulting in a final polymer concentration range of $\mathrm{I} .5-800 \mu \mathrm{g} / \mathrm{ml}$. After 2 hours of polymer treatment, medium was replaced by complete culture medium and the cells were incubated for another 48 hours. Cell viability was assessed by an XTT proliferation assay in which untreated cells were defined as I00\% viable and wells without cells served as a negative control. Absorption of the orange colored formazan salt, formed by metabolic active cells, was determined on a Magellan Tecan Safire II 96 wells platereader at 450 $\mathrm{nm}$ in colorless culture medium.

\subsubsection{Hemolysis}

Hemolytic activity of the polymers was tested as described by Meyer [12] with a few modifications. Human erythrocytes were isolated from freshly obtained citrate treated blood by washing and centrifugation in PBS four times ( $800 \mathrm{~g}$, 10 $\left.\mathrm{min}, 4^{\circ} \mathrm{C}\right)$. After the final washing step, the erythrocyte pellet was diluted Io times in $150 \mathrm{mM} \mathrm{NaCl}$. Polymer solutions were prepared in HBS (HEPES buffered saline, $20 \mathrm{mM}$ HEPES, $\mathrm{pH}$ 7.4, 130

84 - Chapter 5 
$\mathrm{mM} \mathrm{NaCl})$ at $\mathrm{I} .25 \mathrm{mg} / \mathrm{ml}$ and were diluted 8 times. Triton X-Ioo I\% (v/v) in HBS was used as a positive control; plain HBS served as negative control. All solutions were filled out in triplicate in $\mathrm{I} 2 \mathrm{O} \mu \mathrm{l}$ portions in a V-bottom 96 well plate and the plates were preincubated at $37^{\circ} \mathrm{C}$ for $20 \mathrm{~min}$. Then $30 \mu \mathrm{l}$ of erythrocyte suspension was added and the plates were incubated at $37^{\circ} \mathrm{C}$ under constant shaking. After $30 \mathrm{~min}$, the plates were centrifuged $\left(300 \mathrm{~g}\right.$, Io $\mathrm{min}, 20^{\circ} \mathrm{C}$ ), $60 \mu \mathrm{l}$ of supernatant was transferred to a flat bottom 96 well plate and were analyzed for hemoglobin absorption at $405 \mathrm{~nm}$ using a plate reader (Magellan Tecan Safire II).

\subsection{Results and discussion}

\subsubsection{Synthesis and characterization of the copolymers}

Five poly(amido amine) copolymers having $\omega$-hydroxyalkyl side chains with different spacer lengths were synthesized by Michael-type addition polymerization from $N, N^{\prime}$-cystaminebisacrylamide (CBA), ethylene diamine (EDA) and the appropriate aminoalcohol: 2-amino-I-ethanol (AEOL), 3-amino-I-propanol (APrOL), 4-amino-Ibutanol (ABOL), 5-amino-I-pentanol (APOL) or 6-amino-I-hexanol (AHOL). The resulting polymers $\mathrm{p}(\mathrm{CBA}-\mathrm{AEOL} / \mathrm{EDA}), \mathrm{p}(\mathrm{CBA}-\mathrm{APrOL} / \mathrm{EDA}), \mathrm{p}(\mathrm{CBA}-\mathrm{ABOL} / \mathrm{EDA})$, $\mathrm{p}(\mathrm{CBA}-\mathrm{APOL} / \mathrm{EDA})$ and $\mathrm{p}(\mathrm{CBA}-\mathrm{AHOL} / \mathrm{EDA})$ were obtained as a white brittle material with a molar alcohol/EDA ratio that was approximately equal to the $75 / 25$ feed ratio (Table 5.I).

Table 5.1: Polymer characteristics.

\begin{tabular}{llll}
\hline Polymer & $\begin{array}{l}\text { Alcohol/EDA } \\
\text { composition }^{\mathbf{a}}\end{array}$ & $\begin{array}{l}\text { Intrinsic } \\
[\mathbf{n}] \mathbf{( d l / g})^{\mathbf{b}}\end{array}$ & viscosity $^{\text {Buffer capacity }}$ \\
\hline $\mathrm{p}(\mathrm{CBA}-\mathrm{AEOL/EDA)}$ & $72 / 28$ & 0,44 & $68 \%$ \\
$\mathrm{p}(\mathrm{CBA}-\mathrm{APrOL} / \mathrm{EDA})$ & $79 / 21$ & 0,45 & $67 \%$ \\
$\mathrm{p}(\mathrm{CBA}-\mathrm{ABOL} / \mathrm{EDA})$ & $76 / 24$ & 0,36 & $66 \%$ \\
$\mathrm{p}(\mathrm{CBA}-\mathrm{APOL} / \mathrm{EDA})$ & $76 / 24$ & 0,35 & $67 \%$ \\
$\mathrm{p}(\mathrm{CBA}-\mathrm{AHOL/EDA})$ & $77 / 23$ & 0,47 & $86 \%$ \\
\hline
\end{tabular}

(a) Determined by ${ }^{1} \mathrm{H} N \mathrm{NR}$; (b) Determined in an Ubbelohde micro viscosimeter in $100 \mathrm{mM}$ acetate buffer with $\mathrm{pH}$ 4.5; (c) Determined by acid/base titration; Buffer capacity of b-PEI (25 kg/mol) is 15\% (measured under the same conditions).

The molecular weight of the polymers was measured relatively by viscosimetry and expressed as the intrinsic viscosity in a Ioo $\mathrm{mM}$ acetate buffer of $\mathrm{pH}$ 4.5. The intrinsic viscosities are close to each other and are ranging from 0.35 to $0.47 \mathrm{dl} / \mathrm{g}$ (Table 5.I). Assuming comparable solution behavior under the used conditions, differences in 
viscosity reflect differences in molecular weights of these polymers, and from the relatively small difference observed in the viscosity, it may be concluded that the molecular weights are approximately similar. Furthermore, all polymers are supposed to be linear, based on previous results obtained with the synthesis of a similar $\mathrm{p}(\mathrm{CBA}$ $\mathrm{ABOL} / \mathrm{EDA}$ ) polymer [I].

The buffer capacities in the endosomal buffer range between $\mathrm{pH}$ 5.I and $\mathrm{pH} 7.4$ are between $65 \%$ en $70 \%$ for all copolymers, except the polymer with the longest alcohol chain in the series, $\mathrm{p}$ (CBA-AHOL/EDA), which has a higher buffer capacity of $86 \%$. Normally, more hydrophobic species are expected to be less hydrated, which hampers protonation of the tertiary nitrogens in the backbone and results in lower $\mathrm{pK}_{\mathrm{a}}$ values. According to equation $\mathrm{I}$, a protonation equilibrium that falls outside the $\mathrm{pH}$ range of interest will decrease the buffer capacity and therefore the buffer capacity of $\mathrm{p}$ (CBAAHOL/EDA) was expected to be lower instead of being higher. Obviously another phenomenon is occurring during titration of this polymer. It is hypothesized that during the base titration to the acidified solution of the p(CBA-AHOL/EDA) the deprotonation of the polymer chain makes this polymer so much hydrophobic, that it starts to form aggregates or hydrophobic nanoparticles. In these particles, further deprotonation of the tertiary amines from $\mathrm{AHOL}$ as well as the secondary amines from EDA, which are normally largely deprotonated at $\mathrm{pH}$ values higher than 7.4 , is enhanced to fit better in the hydrophobic environment of the nanoparticles. This results in a plateau region in the titration curve and thus contributing to an increased buffer capacity. The titration curve of $\mathrm{p}$ (CBA-AHOL/EDA) (Figure 5.I) indeed shows a longer plateau between $\mathrm{pH} 7.0$ and 7.4 than the other polymers.

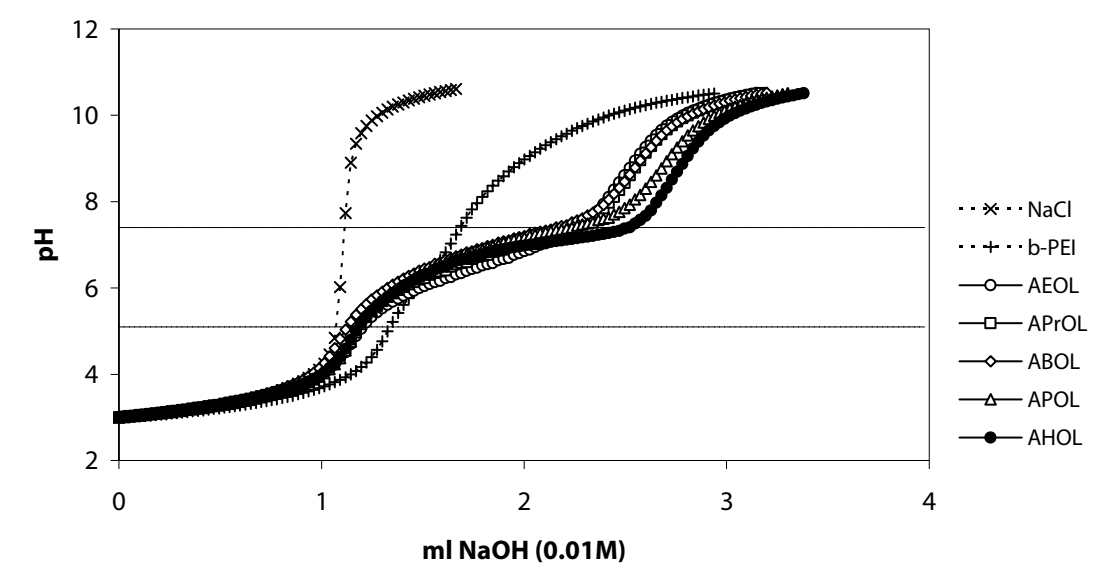

Figure 5.1: Titration curves of the SS-PAA copolymers having various $\omega$-hydroxyalkyl side chains obtained by titration of $0.015 \mathrm{mmol}$ protonable nitrogens (polymer) with $0.01 \mathrm{M}$ sodium hydroxide solution. 
To validate the hypothesis, the polymers were dissolved in PBS with $\mathrm{pH}$ 7.20 in similar concentrations as in the titration experiments and the solutions were studied by dynamic light scattering. Only for p(CBA-AHOL/EDA) well defined particles were detected with sizes around $500 \mathrm{~nm}$ (data not shown); for the other polymers no stable particles could be determined. Count rates during these size measurements are displayed in Figure 5.2 and were by far the highest for the $\mathrm{p}(\mathrm{CBA}-\mathrm{AHOL} / \mathrm{EDA})$ solution, indicating that spontaneous particle formation indeed only occurs for the $\mathrm{p}$ (CBA-AHOL/EDA) polymer.

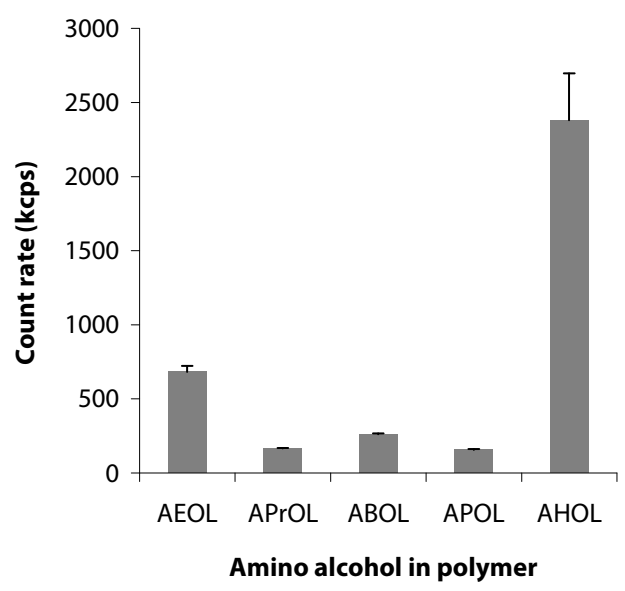

Figure 5.2: Count rates during size measurements of the SS-PAA copolymers having various $\omega$ hydroxyalkyl side chains in a $20 \mathrm{mM}$ PBS buffer $\mathrm{pH}$ 7.2.

\subsubsection{Particle properties}

Endosomal uptake of polyplexes by cells only proceeds with particles that have a relatively small diameter, usually not larger than $200-250 \mathrm{~nm}$, and a positively charged surface. The properties of siRNA polyplexes of the different polymers were studied by dynamic light scattering and in Figure 5.3 the particle size and $\zeta$-potential of the polyplexes are displayed for different polymer/siRNA weight ratios.

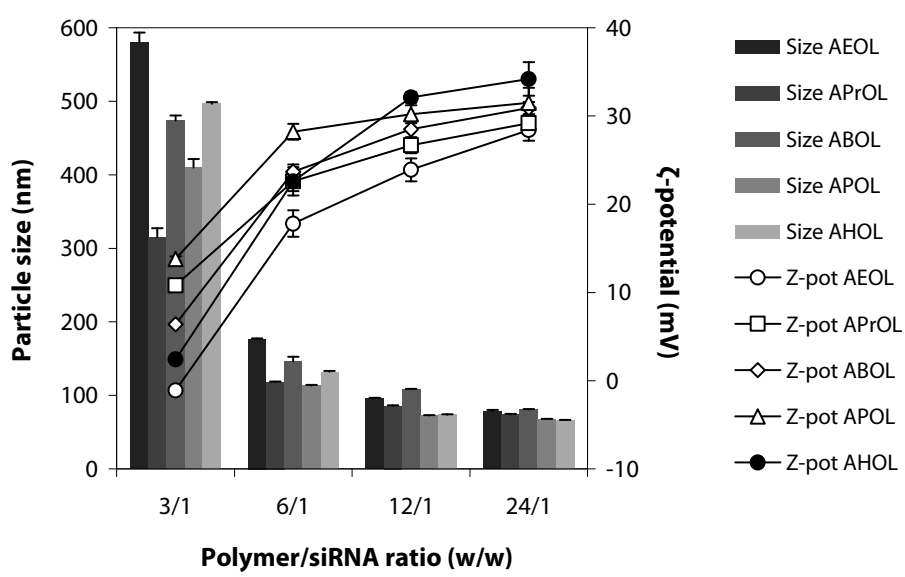

Figure 5.3: Particle size and $\zeta$-potential of complexes of siRNA with SS-PAA copolymers having various $\omega$ hydroxyalkyl side chains, as determined by DLS. 
It is clear that all the polymers show similar complexation properties. An excess of polymer/siRNA weight ratio of 6 is sufficient for the formation of polyplexes smaller than $200 \mathrm{~nm}$ and a positive $\zeta$-potential. Lower amounts of polymer resulted in increased particle size, due to incomplete packaging of the siRNA. The latter was also reflected in low $\zeta$-potentials and incomplete retardation in gel electrophoresis (vide infra). On the other hand, higher excesses of polymer only slightly further decreased the polyplex diameter but gives rise to an increased $\zeta$-potential. It is not expected that these further excess of polymer contributes to a higher silencing potential of the polyplexes, but rather contributes to a possible cytotoxicity of the formulation.

For efficient gene transfer, the polymer should protect the siRNA in the extracellular environment against nucleases. Therefore, siRNA should be well encapsulated into the polyplex. However, as too much polymer (i.e. high polymer/siRNA ratios) can also result in toxic side effects, it is of interest to determine the minimum amount of polymer needed for complete siRNA complexation. This was studied by gel retardation on an agarose gel as is shown in Figure 5.4 (left column). These pictures show that at low polymer/siRNA ratios, the negatively charged siRNA is still able to migrate through the gel, but at higher ratios siRNA is completely retarded by the cationic polymer. $\mathrm{p}(\mathrm{CBA}-\mathrm{AHOL} / \mathrm{EDA})$ shows complete retardation at polymer/siRNA ratios of I2/I and higher, and the other polymers already show complete retardation from 6/I ratio. Furthermore, some ethidium-siRNA complexes are observed at the loading spots, indicating that there is sufficient polymer present to avoid migration through the gel, but insufficient for complete shielding from ethidium complexation. The siRNA encapsulation is complete at weight ratios I2/I and higher for $\mathrm{p}$ (CBA-AEOL/EDA), $\mathrm{p}$ (CBA-APrOL/EDA) and $\mathrm{p}$ (CBA-ABOL/EDA), but a minimum ratio of $24 / \mathrm{I}$ is required for $\mathrm{p}(\mathrm{CBA}-\mathrm{APOL} / \mathrm{EDA})$ and $\mathrm{p}(\mathrm{CBA}-\mathrm{AHOL} / \mathrm{EDA})$. From these observations it is concluded that there is some difference in complexation capacity of the polymers, as more polymer is needed for complete siRNA complexation when the polymer has an increased alcohol side chain length. This may be originated from the increased hydrophobicity of these polymers, making it energetically less favorable to complex siRNA.

Although tight encapsulation of siRNA is necessary for protection during transport to the cell, a quick release of the siRNA in the cytosol is desired for efficient gene silencing. The disulfide units in the backbone of the polymer rapidly reduce in a reductive environment, generated by glutathione, which is present in significant concentrations inside the cell, but at much lower concentrations in the extracellular environment. The intracellular degradation of the polymer is expected to disassemble the polyplexes and subsequently liberate the siRNA, as is schematically represented Chapter 3 (Figure 3.4).

88 - Chapter 5 


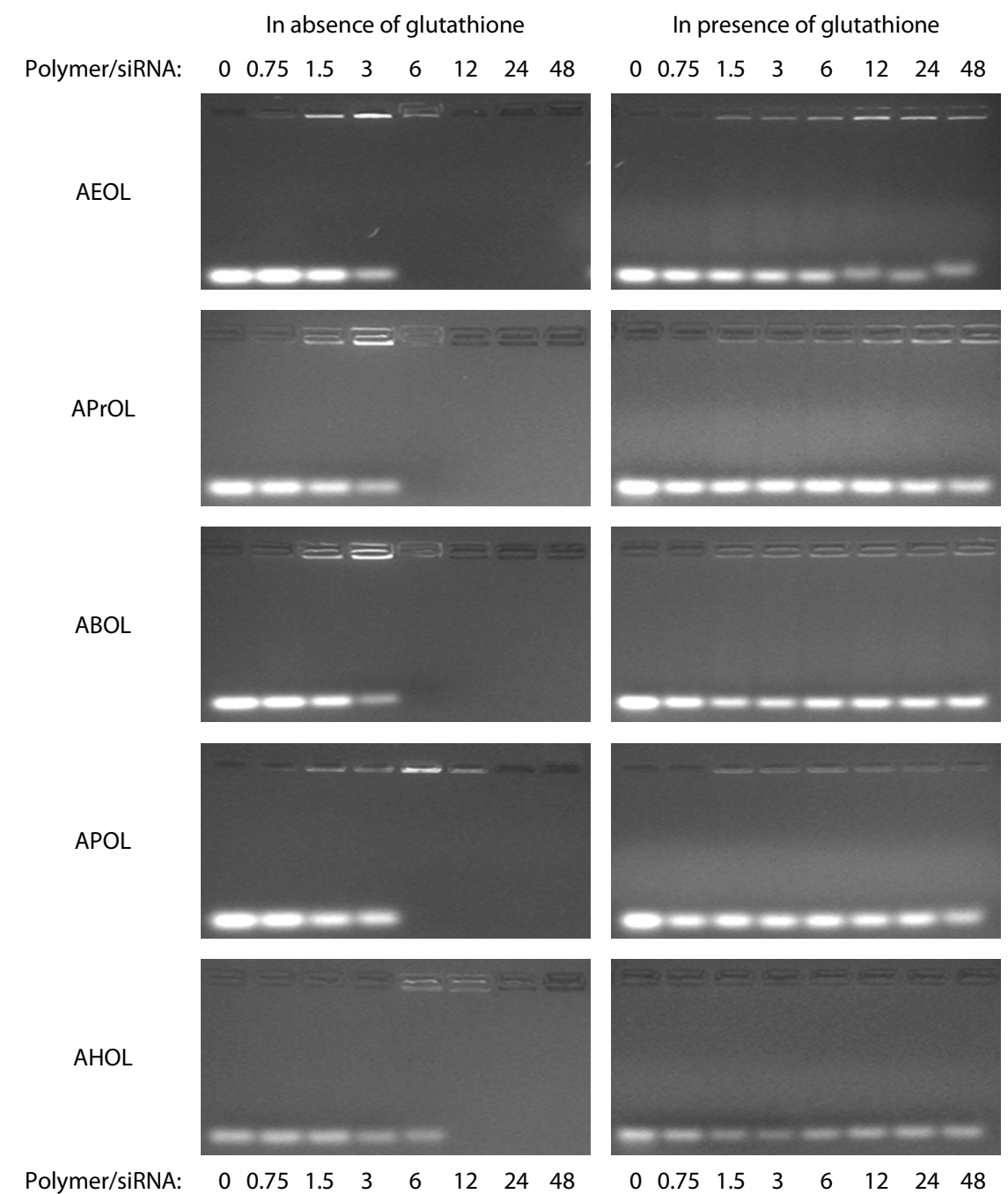

Figure 5.4: Gel retardation profiles of siRNA polyplexes from SS-PAA copolymers having various $\omega$ hydroxyalkyl side from polymer/siRNA w/w ratio 0 (siRNA only) to $48 / 1$ in absence (left) and in presence (right) of $15 \mathrm{mM}$ glutathione.

The reductive degradation by glutathione and the consequent siRNA release was also demonstrated by agarose gel retardation. Polyplexes of seven different polymer/siRNA mass ratios were incubated in $15 \mathrm{mM}$ glutathione and subsequently loaded on a gel. From the right column of Figure 5.4 it is clear that glutathione indeed provoked disassembly of the polyplexes, which resulted in a complete siRNA release at all polymer/siRNA ratios. 


\subsubsection{In vitro gene silencing}

The silencing potential of the polyplexes was evaluated by determination of the knockdown of luciferase expression in Hi299 cells that stably express this enzyme. The luciferase expression of the lysed cells 48 hours after transfection was measured by the luminescent oxidation of luciferin to oxyluciferin and was used as a measure for gene silencing. In Figure 5.5, the residual luciferase expressions are shown.
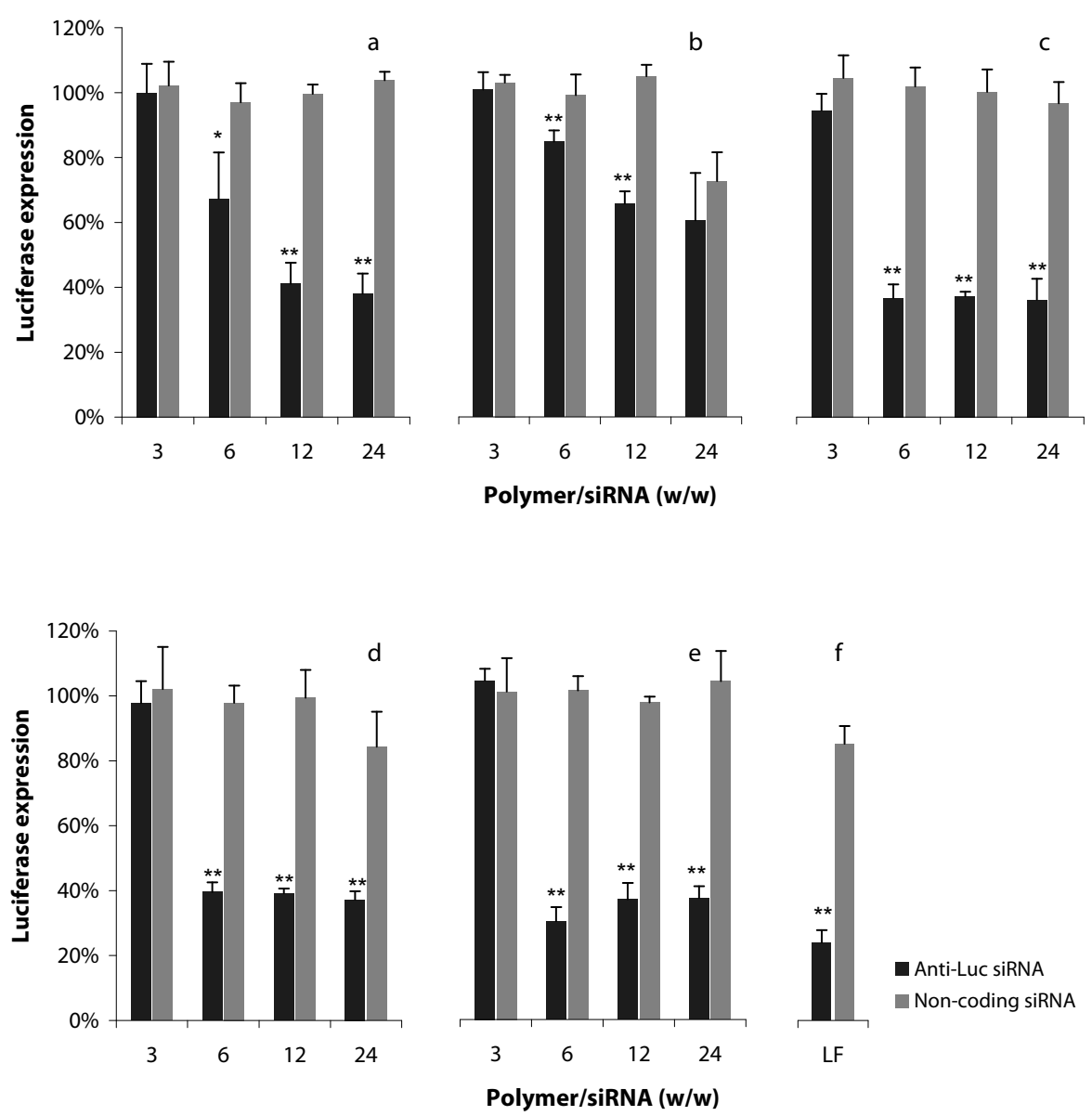

Figure 5.5: Luciferase expression of $\mathrm{H} 1299$ Fluct cells 48 hours after transfection with anti-luciferase siRNA (black) and non-coding control siRNA (grey) with p(CBA-AEOL/EDA) (a), p(CBA-APrOL/EDA) (b), p(CBAABOL/EDA) (c), p(CBA-APOL/EDA) (d), p(CBA-AHOL/EDA) (e). Lipofectamine 2000 (LF) was used as reference transfection agent (f). Each bar value represents the mean \pm SD of $n=3$ or 4 . For statistical analysis of differences between anti-luciferase and non-coding siRNA an unpaired Student's t-test was used ${ }^{*} p<0.05$. $\left.{ }^{* *} \mathrm{p}<0.01\right)$.

90 - Chapter 5 
At the lowest polymer/siRNA weight ratio no or negligible gene silencing was observed. However, at a polymer excess ratio of 6 , p(CBA-ABOL/EDA), p(CBAAPOL/EDA) and $\mathrm{p}$ (CBA-AHOL/EDA) polyplexes showed maximum knockdown values of $60 \%$, corresponding to minimum remaining luciferase expressions around $40 \%$. A higher excess of polymer did not improve the silencing. $\mathrm{p}(\mathrm{CBA}-\mathrm{AEOL} / \mathrm{EDA})$ and $\mathrm{p}(\mathrm{CBA}-$ APrOL/EDA) showed their maximum silencing from a polymer excess of I2 and higher and for $\mathrm{p}(\mathrm{CBA}-\mathrm{AEOL} / \mathrm{EDA})$ the silencing potential for these ratios was similar to the other polymers. The maximal obtained silencing values are comparable to Lipofectamine 2000, which is currently the standard for siRNA delivery. The toxicity of the polyplexes during transfection was evaluated by a parallel session, where the cells were transfected with non-coding siRNA complexes (Figure 5.5b). It turned out that none of the polymers were toxic during the transfection, only p(CBA-APrOL/EDA) and $\mathrm{p}$ (CBA-APOL/EDA) showed a minor toxicity at the highest used weight ratio.

\subsubsection{Cytotoxicity}

The cytotoxicity of the materials to Hi299 Fluct cells was further explored by treating them for two hours (similar to transfection protocol) with polymer solutions in concentrations ranging from $\mathrm{I} .5$ to $800 \mu \mathrm{g} / \mathrm{ml}$ and two days later their proliferation was measured using an XTT assay (Figure 5.6). In the transfection, the highest polymer concentration used was $50 \mu \mathrm{g} / \mathrm{ml}$ (24/I ratio) and as expected from literature [I3-I4], the cytotoxicity of the free polymer was higher than the cytotoxicity of the polyplexes. At low polymer concentrations up to maximal io

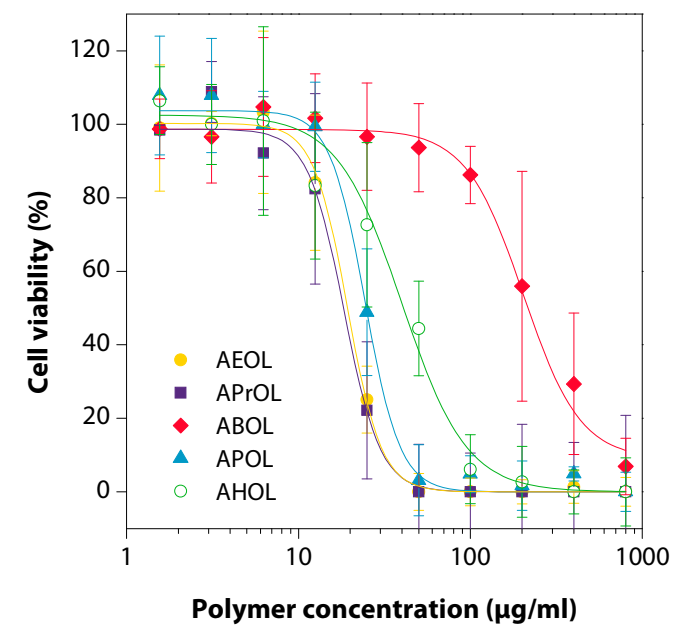

Figure 5.6: Cell viability of H1299 Fluct cells two days after treatment with polymer solutions. Connections between the data points are to visibly improve the data interpretation and were generated by logistic sigmoidal curve fitting. $\mu \mathrm{g} / \mathrm{ml}$, none of the polymers are toxic. $\mathrm{p}(\mathrm{CBA}-\mathrm{AEOL} / \mathrm{EDA}), \mathrm{p}(\mathrm{CBA}-\mathrm{APrOL} / \mathrm{EDA})$ and $\mathrm{p}(\mathrm{CBA}-\mathrm{APOL} / \mathrm{EDA})$ show the fastest decrease in viability by increasing polymer concentrations, reaching complete cell death from $50 \mu \mathrm{g} / \mathrm{ml}$, rapidly followed by $\mathrm{p}(\mathrm{CBA}-\mathrm{AHOL} / \mathrm{EDA})$, that destroyed all cells from Ioo $\mu \mathrm{g} / \mathrm{ml}$ and higher, although the high error margins make it difficult to 
distinguish that sharply between these four polymers. Absolutely striking is however the relatively high polymer concentrations of $\mathrm{p}(\mathrm{CBA}-\mathrm{ABOL} / \mathrm{EDA})$ that were tolerated by the cells. At $100 \mu \mathrm{g} / \mathrm{ml}$, still 10о\% viability was observed and complete cell death was only measured at $800 \mu \mathrm{g} / \mathrm{ml}$, which is almost io times more than all the other polymers. The reason for this much lower cytotoxicity is not completely clear, but may be originated from both the cationic as well as the hydrophobic character of this polymer. Although the underlying mechanisms are complicated and not yet fully understood, it is generally known that a high density of cationic charges induce cytotoxicity by distortion of intracellular membranes [I5]. Furthermore, also hydrophobic moieties interact with cell membranes and can lead to membrane lysis; serious lysis can finally result in cell death. It is beyond the question that both properties can amplify each other [I6-I7], since charge attraction results in closer contact of the hydrophobic alcohol tails with the cell membrane. Apparently the slightly higher charge density in case of the polymers with short alcohol side groups from one side, as well as the increased potential of polymers with longer alcohol side groups to lyse membranes from the other side, increase the cytotoxicity. The ABOL/EDA combination seems to be the optimal polymer composition in the sense that both the hydrophobicity and the charge density are well balanced for a proper cell interaction without cytotoxicity.

\subsubsection{Hemolysis}

To obtain further insight on the effect of longer and more hydrophobic alcohol side chains

on the cytotoxicity, the membranolytic activity of these polymers was evaluated in a hemolytic experiment against human erythrocytes (Figure 5.7). At the concentrations used during transfections, the lysis was almost negligible, except for $\mathrm{p}(\mathrm{CBA}-$ AHOL/EDA), which showed a lysis of $\mathrm{I} 4 \%$ at $50 \mu \mathrm{g} / \mathrm{ml}$, comparable to a polymer/siRNA

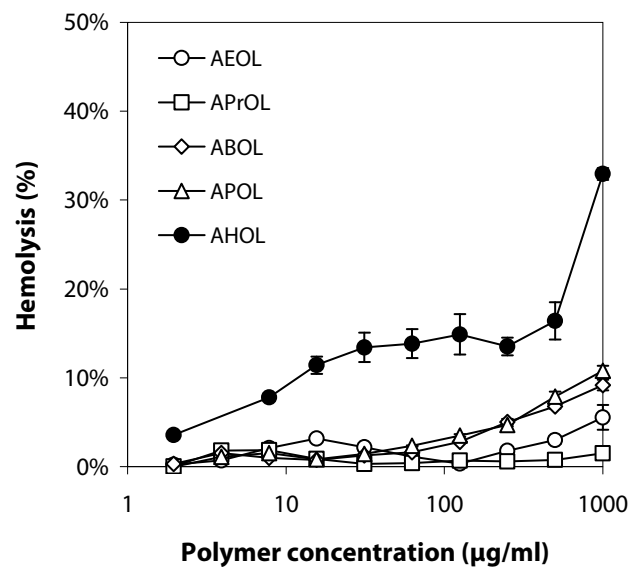

Figure 5.7: Hemoglobin leakage from human erythrocytes after $30 \mathrm{~min}$ incubation in a polymer solution. ratio of 24/I during transfection. Although the total lysis was relatively low, it became clear that increasing hydrophobicity indeed resulted in more disruption of the lipid membrane, as was most 
apparent at the highest polymer concentration. This may explain the higher toxicity of $\mathrm{p}(\mathrm{CBA}-\mathrm{AHOL} / \mathrm{EDA})$ with respect to $\mathrm{p}(\mathrm{CBA}-\mathrm{ABOL} / \mathrm{EDA})$.

\subsection{Conclusions}

For optimal gene silencing, the hydrophilicity/lipophilicity balance of the polymeric vector is believed to play an important role. In order to obtain further understanding of the optimal balance in disulfide-containing poly(amido amine)s (SSPAA), and using the successful $\mathrm{p}(\mathrm{CBA}-\mathrm{ABOL} / \mathrm{EDA})$ as a starting point, we have compared the vector properties of five analogous SS-PAAs with $\omega$-hydroxyalkyl side chains of different chain length. All polymers showed excellent gene silencing properties in Hi299 Fluct cells, but the polymer with the $\omega$-hydroxybutyl side chain appeared to be the least toxic gene carrier. It seemed that in the investigated copolymer series $\mathrm{p}(\mathrm{CBA}-\mathrm{ABOL} / \mathrm{EDA})$ is the polymer with the most optimal hydrophilicity/lipophilicity balance, since polymer analogs with longer as well as with shorter alkyl chain length in the alcohol sidegroups showed enhanced cytotoxicity profiles.

\subsection{Acknowledgement}

Thanks to Jasmin Bühler for doing explorative work on introducing different alcohols in poly(amido amine)s.

\subsection{References}

I. van der Aa, L.J., et al., Optimization of poly(amido amine)s as vectors for siRNA delivery. Journal Of Controlled Release, 20II. I50(2): p. I77-I86.

2. Liu, Z.H., et al., Hydrophobic modifications of cationic polymers for gene delivery. Progress in Polymer Science, 2010. 35(9): p. II44-II62.

3. Kim, H.J., et al., Introduction of stearoyl moieties into a biocompatible cationic polyaspartamide derivative, $P A s p(D E T)$, with endosomal escaping function for enhanced siRNA-mediated gene knockdown. Journal Of Controlled Release, 20IO. I45(2): p. I4I-I48.

4. Alshamsan, A., et al., Formulation and Delivery of siRNA by Oleic Acid and Stearic Acid Modified Polyethylenimine. Molecular Pharmaceutics, 2009. 6(I): p. I2I-I33. 
5. Aravindan, L., et al., Effect of acyl chain length on transfection efficiency and toxicity of polyethylenimine. International Journal Of Pharmaceutics, 2009. 378(I-2): p. 20I-2IO.

6. Kim, W.L., et al., Cholesteryl oligoarginine delivering vascular endothelial growth factor siRNA effectively inhibits tumor growth in colon adenocarcinoma. Molecular Therapy, 2006. I4(3): p. 343-350.

7. $\quad$ Philipp, A., et al., Hydrophobically Modified Oligoethylenimines as Highly Efficient Transfection Agents for siRNA Delivery. Bioconjugate Chemistry, 2009. 20(II): p. 2055-206I.

8. Dehshahri, A., et al., Gene transfer efficiency of high primary amine content, hydrophobic, alkyl-oligoamine derivatives of polyethylenimine. Biomaterials, 2009. 30(25): p. 4I87-4194.

9. Thomas, M. and A.M. Klibanov, Enhancing polyethylenimine's delivery of plasmid DNA into mammalian cells. Proceedings of the National Academy of Sciences of the United States of America, 2002. 99(23): p. I4640-I4645.

Io. Lin, C., et al., Novel Bioreducible Poly(amido amine)s for Highly Efficient Gene Delivery. Bioconjugate Chemistry, 2007. I8(I): p. I38-I45.

II. Anderson, D.G., et al., Structure/property studies of polymeric gene delivery using a library of poly(beta-amino esters). Molecular Therapy, 2005. II(3): p. 426-434.

I2. Meyer, M., et al., A dimethylmaleic acid - melittin-polylysine conjugate with reduced toxicity, pH-triggered endosomolytic activity and enhanced gene transfer potential. Journal of Gene Medicine, 2007. 9(9): p. 797-805.

I3. Fischer, D., et al., In vitro cytotoxicity testing of polycations: influence of polymer structure on cell viability and hemolysis. Biomaterials, 2003. 24(7): p. II2I-II3I.

I4. Boeckle, S., et al., Purification of polyethylenimine polyplexes highlights the role of free polycations in gene transfer. Journal of Gene Medicine, 2004. 6(Io): p. IIO2-IIII.

15. Lv, H.T., et al., Toxicity of cationic lipids and cationic polymers in gene delivery. Journal of Controlled Release, 2006. II4(I): p. Ioo-Io9.

I6. Narita, T., et al., Effects of charge density and hydrophobicity of ionene polymer on cell binding and viability. Colloid and Polymer Science, 2000. 278(9): p. 884-887.

I7. Narita, T., et al., Kinetic study of cell disruption by ionic polymers with varied charge density. Colloid and Polymer Science, 2001. 279(2): p. 178-183. 


\title{
Chapter
}

\author{
Introducing pyridyl disulfides in \\ $p(C B A-A B O L / E D A)$ - crosslinking of \\ polyplexes
}




\begin{abstract}
A pyridyl disulfide-containing monomer (PDA) was synthesized to introduce thiol reactive sidegroups in disulfide (SS-PAAs) and non-disulfide-containing poly(amido amine)s (CC-PAAs) for siRNA delivery. The PDA sidegroups were used for reversible post-crosslinking of polyplexes by a bifunctional thiol molecule in order to improve the stability of the polyplexes, which should finally contribute to the development of successful siRNA vectors for in vivo applications. Network formation in the nanoparticles was approved and size and surface potential of siRNA containing polyplexes were not affected by the crosslinking reaction. The expected increase in stability of polyplexes against heparin as competing polyanion was however not observed. It is supposed that the pores in the polymer network around the siRNA are still large enough for siRNA and heparin to diffuse in and out. The crosslinked polyplexes showed lower gene silencing capacity. For the maximum crosslinking degree, this could be attributed to complex destabilization, and for lower tested crosslinking degrees a delay in gene silencing is more likely since more disulfides need to be reduced for siRNA release.
\end{abstract}

\title{
6.1 Introduction
}

In the past decades a large range of different polymeric gene delivery systems has been developed in order to treat a variety of diseases by gene therapy. Poly-L-lysine (PLL) and poly(ethyleneimine) (PEI) were among the first explored cationic materials, since they possess an excellent complexation capability originating from their high cationic charge density. Furthermore, PEI is capable to escape the endosomal pathway efficiently due to the so called proton sponge effect [I]. However, these polymers turned out to be highly toxic when administered at increased concentrations, necessary for in vivo therapy. Besides modifications of PLL and PEI to overcome this toxicity problem, also new materials were employed, like chitosan, poly(amido ester)s (PAE), poly(amido amine)s (PAA) and poly(amido amine) dendrimers (PAMAM), all showing improved cytotoxicity profiles. In optimized in vitro experiments, all these polymeric systems show one by one good transfection results, but in vivo conditions are much more challenging and limit the use of these polymers without extra adjustments. Especially the systemic application of cationic polyplexes is difficult, since injection in the bloodstream requires a colloidal stability to prevent aggregation by high ionic strengths or anionically charged proteins like albumin. Furthermore, stability against shear forces of the bloodflow is necessary and stealth properties are required to protect the particles from phagocytosis by the immune system. Coating of polyplexes with hydrophilic polymers like poly(ethylene glycol) (PEG) or poly[ $N$-(2-hydroxypropyl)methacrylamide $]$

96 - Chapter 6 
(PHPMA) [2] is a proven strategy to increase the colloidal stability against salt and competing polyanions and prevent phagocytosis. However, besides the steric stabilization by PEG or PHPMA by shielding of the polyplexes, there is still a risk of dissociation of polyplexes [3-4], resulting in premature degradation of the nucleic acids. Crosslinking of the cationic polymer to create a network around the nucleic acid contents makes the process of polyplex formation irreversible. This results in robust complexes that having the nucleic acids trapped inside and are more stable against dissociation [4-7]. Although high extracellular stabilities are obtained by crosslinking, efficient gene expressions require an intracellular lability, which was assured by including disulfide linkers that are known to provide rapid intracellular degradation by increased glutathione levels [8]. Many efforts were put in the development of reducible crosslinked polycations, broadly classified in pre-crosslinking of the polycation [9-II] and post-crosslinking of the polyplex [3-7, I2]. Only the latter strategy can entrap DNA or RNA in covalent cage-like structures and is supposed to provide the best protection against dissociation. Therefore we will focus only on post-crosslinking of polyplexes in this study. In earlier studies PEI polyplexes and PLL polyplexes were crosslinked before by homobifunctional, reducible and amine reactive crosslinkers like dimethyl 3,3'dithiopropionimidate (DTBP) or Lomants reagent [3, 5-7, I3]. Pre-modification with sulfhydryls of chitosan and PEG-PLL copolymers was done previously to enable postcrosslinking of the polyplexes by thiol oxidation [4, I2]. These post-crosslinking reactions generally preserved the original particle sizes and surface potentials, unless cationic groups were sacrificed to establish crosslinks. Improved colloidal stability of the complexes was found indeed, but despite the reducible character, the therapeutic effects were usually decreased or delayed as a result of the crosslinking. Kissel and coworkers observed also an increased circulation and biodistribution in mice for crosslinked PEI [7]. Typically, all these results were achieved with DNA polyplexes and surprisingly only a few studies are published with siRNA or other short nucleotides. Kataoka stabilized complexes of antisense oligonucleotides (ODN) or siRNA and PEGPLL by thiol oxidation [I4-I5]. Crosslinked ODN complexes were subjected to polyanions and proved to be more stable than their uncrosslinked counterparts. siRNA complexes with PEG-PLL were not evaluated for their stability but maximum silencing was observed with polyplexes having I4\% primary amine crosslinking. siRNA was complexed in thiolated hyaluronic acid nanogels by Park and coworkers [I6]. Although disulfide crosslinking was primarily used to form the nanogels rather than to stabilize the particles, these nanogels showed good silencing properties.

Recently, we have developed a disulfide-based poly(amido amine) p(CBA$\mathrm{ABOL}_{75} / \mathrm{EDA}_{25}$ ) (chapter 3-5), which proved to be a very successful carrier for siRNA delivery in vitro. To extend this success in the direction of in vivo delivery, it is necessary to improve the carrier in terms of stability in physiological environments. 
Crosslinking (this chapter) and PEGylation (chapter 7) of the polyplexes are expected to contribute substantially to extracellular stability. It is preferred to modify the polyplexes after the self-assembling complex formation of nucleotide and polycation since both crosslinking as well as PEGylation would interfere in the polyplex formation. To allow post-modification of polyplexes, pyridyl disulfide sidegroups were introduced in the poly(amido amine) copolymer. Pyridyl disulfides are frequently used moieties in biological conjugation reactions [17], since these compounds are highly reactive towards sulfhydryl groups in a trans disulfide reaction that forms a new disulfide linkage under expulsion of the stable 2-pyridylthione group (Scheme 6.I). The major advantages of this post-modification reaction is its feasibility under physiological conditions after polyplex formation and the intracellular reversibility, since all coupling reactions yield bioreducible disulfide bonds. Additionally, (expensive) ligands do not have to be exposed to harsh polymerization conditions, are not spilled (partially) in the polymer purification process, it is not necessary to synthesize new polymers to test every subtle variation and cationic charge of the polymer is preserved in these post-modifications. Only a few examples are known where pyridyl disulfides are included in poly(amido amine)s. Ranucci et al. used the pyridyl disulfide for the coupling of peptides or cholesterol to form hydrophobic core containing nanoparticles for drug delivery [I8-I9]. Garnett et al. mixed a pyridyl disulfide-containing PAA with a thiol containing PAA and DNA to form crosslinked polyplexes for use as water tracer particles [I8]. Structurally related poly( $\beta$-amino ester)s containing pyridyl disulfides were used for postmodification with RGD of DNA containing polyplexes [20].

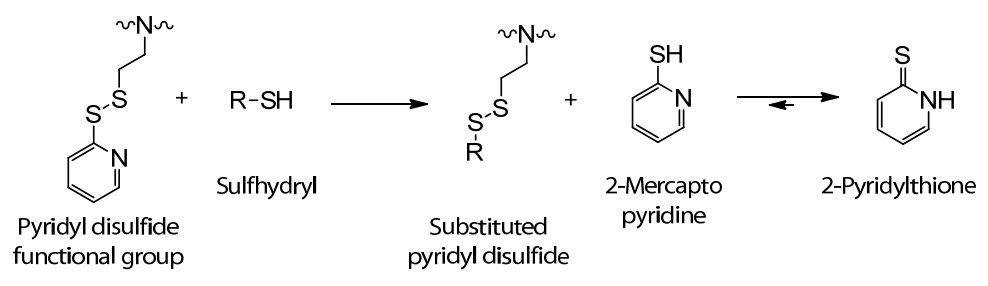

Scheme 6.1: Schematic representation of the trans disulfide reaction between the pyridyl disulfide and a sulfhydryl molecule. The released 2-mercaptopyridine is rapidly tautomerized to the non-reactive 2pyridylthione.

In this study we introduced pyridyl disulfide sidegroups in $\mathrm{p}\left(\mathrm{CBA}-\mathrm{ABOL}_{75} / \mathrm{EDA}_{25}\right)$ by copolymerizing the amine-containing 2-(pyridyldithio)-ethylamine monomer (PDA) in the polymer synthesis. siRNA polyplexes of this polymer were subsequently crosslinked by the addition of the bifunctional thiol bis(2-mercaptoethyl) ether (MEE) as is schematically shown in Figure 6.I. The crosslinking reaction between thiols and PDA is irreversible since the released 2-mercapto pyridine rapidly tautomerizes to the non- 
reactive 2-pyridylthione. In this study we investigated the formation and stability of the crosslinked polyplexes and evaluated how the excellent silencing properties of $\mathrm{p}(\mathrm{CBA}-$ $\mathrm{ABOL}_{75} / \mathrm{EDA}_{25}$ ) were affected by the crosslinking.

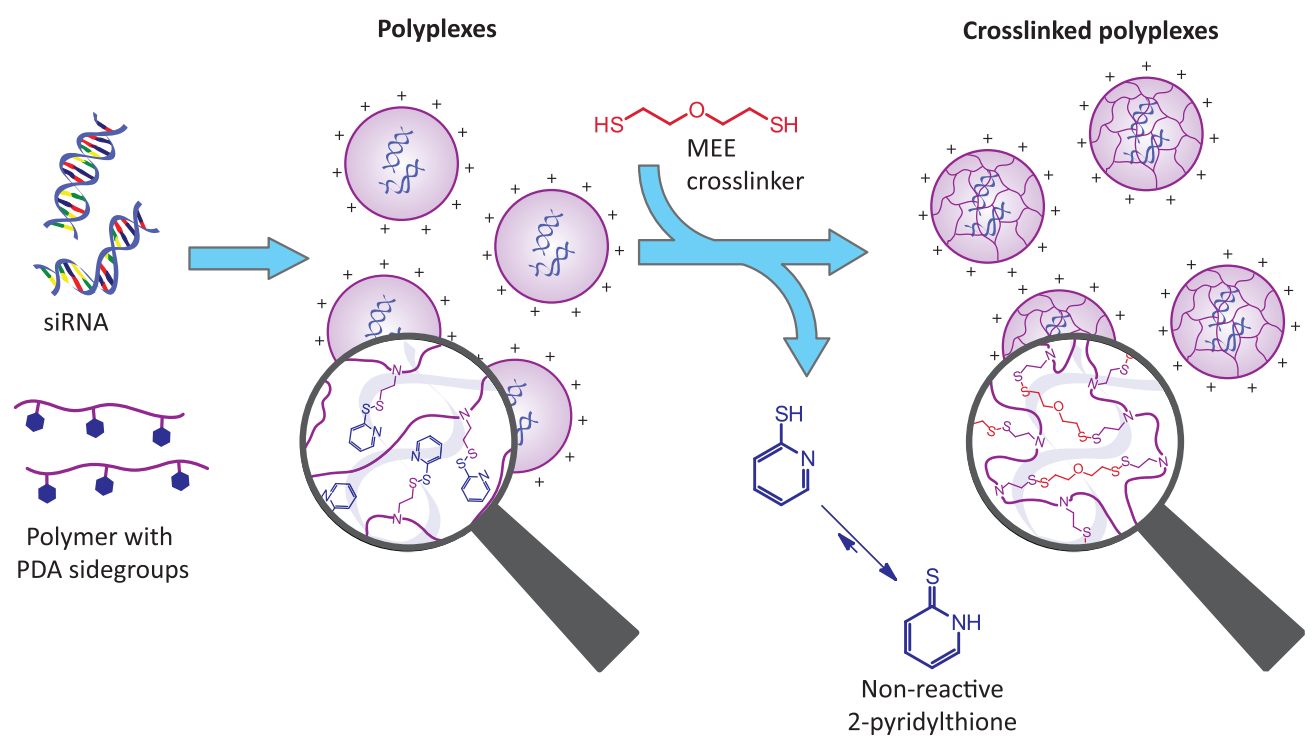

Figure 6.1: Schematic representation of the polyplex formation with siRNA and PDA containing polymer, followed by crosslinking with the bifunctional thiol MEE (bis(2-mercaptoethyl) ether).

\subsection{Materials and methods}

\subsubsection{Materials}

All chemicals and reference materials, 2,2'-dipyridyl disulfide (Acros), cysteamine hydrochloride (Fluka), 4-amino-I-butanol (ABOL, Merck), ethylene diamine (EDA, Aldrich), $\quad N, N$-cystaminebisacrylamide (CBA, Polysciences), I,6hexamethylenebisacrylamide (HBA, ABCR), 2-mercaptoethanol (Acros), bis(2mercaptoethyl) ether (MEE, Aldrich), 2,3-dimercapto-I-propanol (DMP, Aldrich), heparin (Celsus Laboratories Inc) and Lipofectamine 2000 (Invitrogen) were purchased in the highest purity and used without further purification. For culturing the Hi299 Fluct cells RPMI I640 medium (Lonza) completed with 2\% (v/v) PennStrepp (Lonza), I\% $(\mathrm{v} / \mathrm{v})$ glutamine (Lonza) and Io\% $(\mathrm{v} / \mathrm{v})$ fetal bovine serum (Lonza) was used. Negative control siRNA was purchased from Qiagen, anti-luciferase siRNA was kindly supplied by the University of Utrecht. Luciferase assay reagent was obtained from Promega. 


\subsubsection{Synthesis of 2-(pyridyldithio)-ethylamine hydrochloride (PDA.HCl)}

PDA.HCl was synthesized as reported before in [20]. I.9og ( $16.7 \mathrm{mmol}$, req.) cysteamine hydrochloride dissolved in $\mathrm{I} 4 \mathrm{ml}$ methanol was added drop wise to a solution of $7.37 \mathrm{~g}$ ( $33.4 \mathrm{mmol}, 2$ eq.) 2,2'-dipyridyl disulfide and I.6 ml glacial acetic acid in $42 \mathrm{ml}$ methanol under a nitrogen atmosphere. After $48 \mathrm{~h}$ of reaction at room temperature, the mixture was concentrated under reduced pressure and precipitated by the addition of Ioo $\mathrm{ml}$ cold diethyl ether. The precipitation was repeated six times to yield a white crystalline powder. Yield: $61 \%$. ${ }^{\mathrm{H}} \mathrm{H}$ NMR $\left(\mathrm{D}_{2} \mathrm{O}\right) \delta(\mathrm{ppm}): 3.04(\mathrm{t}, 2 \mathrm{H}$, $\mathrm{NH}_{2} \mathrm{CH}_{2} \mathrm{CH}_{2} \mathrm{~S}$ ); 3.28 (t, $\left.2 \mathrm{H}, \mathrm{NH}_{2} \mathrm{CH}_{2} \mathrm{CH}_{2} \mathrm{~S}\right) ; 7.26$ (m, IH, SCCHCHCHCHN); 7.69 (m, $\mathrm{IH}, \quad \mathrm{SCCHCHCHCHN}) ; \quad 7.76(\mathrm{~m}, \quad \mathrm{IH}, \quad \mathrm{SCCHCHCHCHN}) ; 8.39 \quad(\mathrm{~m}, \quad \mathrm{IH}$,

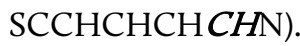

\subsubsection{Synthesis of the reducible $\mathrm{p}$ (CBA-ABOL/EDA/PDA) copolymers (SS-PAA)}

The reducible copolymers were synthesized by Michael addition polymerization of 4-amino-I-butanol (ABOL), ethylene diamine (EDA) and 2-(pyridyldithio)-ethylamine hydrochloride (PDA. $\mathrm{HCl}$ ) with $N, N$ '-cystaminebisacrylamide (CBA) in presence of the $\mathrm{CaCl}_{2}$ catalyst [2I] and shown in general in Scheme 6.2. In a typical example $500 \mathrm{mg}$ (I.93 mmol) CBA, $96 \mathrm{mg}$ (I.08 mmol) ABOL and $107 \mathrm{mg}(0.48 \mathrm{mmol})$ PDA. $\mathrm{HCl}$ were dissolved in $\mathrm{I} .5 \mathrm{ml}$ methanol / water $(3 / \mathrm{I} \mathrm{v} / \mathrm{v})$ containing $200 \mathrm{mM}$ of calcium chloride and were allowed to react at $70^{\circ} \mathrm{C}$ in the dark in a nitrogen atmosphere. Ioo $\mu l 5 \mathrm{M} \mathrm{NaOH}$ solution in water was added to the reaction mixture to neutralize the $\mathrm{HCl}$ on PDA.HCl monomer. The reaction mixture became homogeneous within one hour. After 24 hours of prepolymerization, $22.5 \mathrm{mg}(0.36 \mathrm{mmol})$ EDA was added and the reaction was proceeded for another 24 hours. Then the polymerization was terminated by addition of a Io\% molar excess EDA, to consume remaining toxic acrylamide endgroups. After termination, the reaction mixture was diluted with hydrochloric acid (IM) and water, purified by ultrafiltration ( $\mathrm{MWCO}$ 1ооо, $\mathrm{pH}_{5}$ ) and recovered as its $\mathrm{HCl}$ salt by lyophilization. Yield: $4 \mathrm{I} 5 \mathrm{mg}(57 \%)$; [n]: $0.18 \mathrm{dl} / \mathrm{g}$; ${ }^{\mathrm{I}} \mathrm{H} \mathrm{NMR}\left(\mathrm{D}_{2} \mathrm{O}\right) \delta(\mathrm{ppm})=\mathrm{I} .58(\mathrm{~m}, 2 \mathrm{H}$, $\left.\mathrm{CH}_{2} \mathrm{CH}_{2} \mathrm{NR}\right) ; \mathrm{I} .78\left(\mathrm{~m}, 2 \mathrm{H}, \mathrm{CH}_{2} \mathrm{CH}_{2} \mathrm{OH}\right) ; 2.69$ (t, $\left.4 \mathrm{H}, \mathrm{NHCH} \mathrm{CH}_{2} \mathrm{NH}\right) ; 2.76(\mathrm{t}, 2 \mathrm{H}$, $\mathrm{CH}_{2} \mathrm{CONH}$ ); 2.82 (t, $4 \mathrm{H}, \mathrm{CH}_{2} \mathrm{SSCH}$ ); 3.08 (m, $4 \mathrm{H} \mathrm{RNCH}_{2} \mathrm{CH}_{2} \mathrm{SS}$-ring); $3.2 \mathrm{I}(\mathrm{t}, 2 \mathrm{H}$, $\mathrm{CH}_{2} \mathrm{CH}_{2} \mathrm{NR}$ ); 3.32 (t, $\left.2 \mathrm{H}, \mathrm{COCH}_{2} \mathrm{CH}_{2} \mathrm{NH}\right) ; 3.44$ (t, $\left.4 \mathrm{H}, \mathrm{CH}_{2} \mathrm{NRCH}_{2}\right) ; 3.5 \mathrm{I}(\mathrm{t}, 4 \mathrm{H}$, $\mathrm{NHCH} \mathrm{CH}_{2} \mathrm{SSCH}_{2} \mathrm{CH}_{2} \mathrm{NH}$ ); 3.6I (t, $2 \mathrm{H}, \mathrm{CH}_{2} \mathrm{OH}$ ); 7.28 (s, IH, SCCHCHCHCHN); 7.82 (s, $2 \mathrm{H}, \mathrm{SCCH} C H C H C H N) ; 8.38$ (s, IH, SCCHCHCHCHN).

\subsubsection{Synthesis of the non-reducible $p$ (HBA-ABOL/EDA/PDA) copolymers (CC-PAA)}

The non-reducible copolymers were synthesized under the same conditions as described for the reducible $\mathrm{p}(\mathrm{CBA}-\mathrm{ABOL} / \mathrm{EDA} / \mathrm{PDA})$ copolymers, employing $\mathrm{r}, 6$ -

$100 \cdot$ Chapter 6 
hexamethylenebisacrylamide (HBA) instead of CBA. ${ }^{\mathrm{I}} \mathrm{H}$ NMR $\left(\mathrm{D}_{2} \mathrm{O}\right) \delta(\mathrm{ppm})=\mathrm{I} .27(\mathrm{~m}$, ${ }_{4} \mathrm{H}, \mathrm{CH}_{2} \mathrm{CH}_{2} \mathrm{CH}_{2} \mathrm{CH}_{2} \mathrm{CH}_{2} \mathrm{CH}_{2}$ ); I. 46 (m, $\left.4 \mathrm{H}, \mathrm{CH}_{2} \mathrm{CH}_{2} \mathrm{CH}_{2} \mathrm{CH}_{2} \mathrm{CH}_{2} \mathrm{CH}_{2}\right) ; \mathrm{I} .58(\mathrm{~m}, 2 \mathrm{H}$, $\left.\mathrm{CH}_{2} \mathrm{CH}_{2} \mathrm{NR}\right) ; \mathrm{I} .78\left(\mathrm{~m}, 2 \mathrm{H}, \mathrm{CH}_{2} \mathrm{CH}_{2} \mathrm{OH}\right) ; 2.65$ (t, $\left.4 \mathrm{H}, \mathrm{NHCH} \mathrm{CH}_{2} \mathrm{NH}\right) ; 2.73(\mathrm{t}, 2 \mathrm{H}$, $\mathrm{CH}_{2} \mathrm{CONH}$ ); 3.06 (m, $4 \mathrm{H} \mathrm{RNCH} \mathrm{CH}_{2} \mathrm{SS}$-ring); 3.I4 (t, $4 \mathrm{H}, \mathrm{CH}_{2} \mathrm{CH}_{2} \mathrm{CH}_{2} \mathrm{CH}_{2} \mathrm{CH}_{2} \mathrm{CH}_{2}$ ); 3.2I (t, $2 \mathrm{H}, \mathrm{CH}_{2} \mathrm{CH}_{2} \mathrm{NR}$ ); 3.32 (t, $2 \mathrm{H}, \mathrm{COCH}_{2} \mathrm{CH}_{2} \mathrm{NH}$ ); 3.43 (t, $4 \mathrm{H}, \mathrm{CH}_{2} \mathrm{NRCH}$ ); 3.6I (t, $\left.2 \mathrm{H}, \mathrm{CH}_{2} \mathrm{OH}\right) ; 7.3 \mathrm{I}(\mathrm{s}, \mathrm{IH}, \mathrm{SCCHCHCHCHN}) ; 7.79(\mathrm{~s}, 2 \mathrm{H}, \mathrm{SCCH} C H C H C H N) ; 8.40(\mathrm{~s}$, $\mathrm{IH}, \mathrm{SCCHCHCHCHN)}$.

\subsubsection{Viscosimetry measurements}

Viscosity measurements were performed in an Ubbelohde micro viscosimeter in a thermostated bath at $25^{\circ} \mathrm{C}$. The polymers were freshly lyophilized before preparing the polymer solutions, to guarantee that hygroscopic moisture attraction did not influence the concentration. Polymers were dissolved in a sodium acetate buffer (Ioo mM, pH 4.5) at a concentration of $2.5 \mathrm{mg} / \mathrm{ml}$ at least 4 hours before viscosity measurements. For the determination of network formation, the polymers were dissolved in demineralized water, the $\mathrm{pH}$ was adjusted to 7.4 and the final polymer concentration was Io $\mathrm{mg} / \mathrm{ml}$. The crosslinkers MEE and DMP were also dissolved in demineralized water in the appropriate concentration and mixed with the polymer solution in a I/I volume ratio. In case of post oxidation one hour after crosslinking 2.5 eq. of iodine $\left(\mathrm{I}_{2}\right)$ were added from a concentrated aqueous $\mathrm{I}_{2} / \mathrm{KI}$ solution $\left(\left[\mathrm{I}_{2}\right]=0.5 \mathrm{M},[\mathrm{KI}]=\mathrm{I} \mathrm{M}\right)$. After one hour incubation the crosslinked polymer solutions were mixed with a sodium acetate buffer $(200 \mathrm{mM}$, $\mathrm{pH} 4.5$ ) in a I/I volume ratio too, resulting in a final polymer solution of $2.5 \mathrm{mg} / \mathrm{ml}$ in a IOO $\mathrm{mM}$ sodium acetate buffer of $\mathrm{pH} 4.5$.

\subsubsection{UV measurements}

Polymers were dissolved in a $20 \mathrm{mM}$ phosphate buffer $\mathrm{pH} 7.4$ at a concentration of $0.3 \mathrm{mg} / \mathrm{ml}$ and mixed I:I with a mercaptoethanol solution containing ro eq. of mercaptoethanol to the theoretical PDA content (feed ratio in polymerization). After one hour incubation at room temperature the absorbance of the released 2pyridylthione was measured at a wavelength of $343 \mathrm{~nm}$ on a Cary 300 Bio UV-Visible spectrophotometer. A calibration series of solutions with known concentrations of 2pyridylthione was finally used to convert the absorbance to a concentration.

\subsubsection{Polyplex preparation and crosslinking}

Polyplexes were prepared in HEPES buffered glucose (HBG: $20 \mathrm{mM}$ HEPES, pH $7.4,5 \mathrm{wt} \%$ glucose) in a polymer/siRNA weight ratio of $24 / \mathrm{I}$, containing $6.25 \mu \mathrm{g} / \mathrm{ml}$ 
siRNA. The polymer solution was added to the siRNA solution in a volume ratio of 4/I, followed by $5 \mathrm{~s}$ vortexing and $30 \mathrm{~min}$ incubation at room temperature. Subsequently the polyplexes were crosslinked by mixing a polyplex solution with a MEE solution (in pure water) of appropriate concentration in a volume ratio of Io/I, followed by incubation for I hour at room temperature. Non-crosslinked polyplexes were mixed with plain water in the same volume ratio of Io/r.

\subsubsection{Polyplex properties}

All polyplexes were prepared and crosslinked as described above at a polymer/siRNA weight ratio of 24/I. The hydrodynamic diameter and the $\zeta$-potential were measured by dynamic light scattering on a Zetasizer Nano ZS (Malvern Instruments) at $25^{\circ} \mathrm{C}$.

\subsubsection{Gel retardation}

Polyplexes containing $6.25 \mu \mathrm{g} / \mathrm{ml}$ siRNA were prepared and crosslinked as described above in the polymer/siRNA weight ratio 24/I. $33 \mu \mathrm{l}$ samples of these polyplex solution were mixed with $3 \mu \mathrm{l}$ of heparin solutions with different concentrations, expressed as a heparin/siRNA weight ratio. After 30 minutes incubation with heparin, 25 $\mu \mathrm{l}$ of polyplex solution was mixed with $4 \mu \mathrm{l}$ of loading buffer and loaded on a $4.0 \mathrm{wt} \%$ agarose gel containing $0.25 \mu \mathrm{M}$ ethidium bromide. Electrophoresis was performed for 60 min at $90 \mathrm{~V}$ in a TAE running buffer ( $40 \mathrm{mM}$ tris(hydroxymethyl)aminomethane, 20 $\mathrm{mM}$ acetic acid, Io mM EDTA, pH 8,o) supplemented with $0.25 \mu \mathrm{M}$ ethidium bromide. After electrophoresis, pictures were taken on a Biorad Gel Doc 2000 under UV illumination and analyzed using Biorad Multi Analyst software version I.I.

\subsubsection{In vitro gene silencing}

Knockdown efficiency was determined by silencing luciferase expression in $\mathrm{NCl}$ Hi299 cells, stably expressing firefly luciferase. Knockdown and cell viability were evaluated in two parallel sessions, using anti-luciferase and non-coding siRNA, respectively. Cells were seeded in 96 well plates with a density of 8000 cells per well. After $24 \mathrm{~h}$ incubation at $37^{\circ} \mathrm{C}$ in a humidified atmosphere containing $5 \% \mathrm{CO}_{2}$, medium was replaced with Ioo $\mu$ fresh medium without FBS. Polyplexes containing $6.25 \mu \mathrm{g} / \mathrm{ml}$ siRNA at were prepared at five different polymer/siRNA weight ratios (3/I, 6/I, I2/I, 24/I and 48/I) and crosslinked as described above. Lipofectamine 2000 was used as a reference and complexes were prepared according to the manufacturer's protocol. Polyplexes ( $22 \mu \mathrm{l}$ per well) were added to the cells in quinto after I hour incubation with

$102 \cdot$ Chapter 6 
fresh medium, resulting in a final siRNA concentration of $66 \mathrm{nM}$. After 2 hours of transfection, polyplex medium was replaced by complete culture medium and the cells were incubated for another 48 hours. Cells were lysed in a freeze/thaw cycle and $50 \mu \mathrm{l}$ of the cell lysate was mixed with $50 \mu$ luciferase assay reagent containing the substrate luciferin. After Ioo - 220 seconds (in this timeframe the emitted light is constant - data not shown) the luciferase activity was determined by measuring the luminescence at $25^{\circ} \mathrm{C}$ for 4 seconds on a PerkinElmer 1420 Victor ${ }^{3}$ plate reader. Luciferase activity of untreated cells was defined as Ioo\% expression.

\subsubsection{Network formation}

Polymers were dissolved in demineralized water, the $\mathrm{pH}$ was adjusted to 7.4 and the final polymer concentration was $150 \mu \mathrm{g} / \mathrm{ml}$. Iooo $\mu \mathrm{l}$ of polymer solution was mixed with Ioo $\mu$ of MEE solutions (in demineralized water) with the appropriate concentration. After I hour of incubation at room temperature, particle sizes and accompanying count rates were measured by dynamic light scattering on a Zetasizer Nano ZS (Malvern Instruments) at $25^{\circ} \mathrm{C}$. Subsequently, the $\mathrm{pH}$ was reduced with o.oIM hydrochloric acid and after I hour of incubation the particles size and the accompanying count rates were measured again.

\subsection{Results and discussion}

\subsubsection{Design and synthesis of crosslinkable poly(amido amine)s}

An amine containing pyridyl disulfide monomer was synthesized by reaction of 2,2'-dipyridyl disulfide with cysteamine hydrochloride (Scheme 6.2a). The resulting 2(pyridyldithio)-ethylamine (PDA) was obtained as its hydrochloride salt in 61\% yield as a white crystalline material. Subsequently, three reducible poly(amido amine) copolymers (SS-PAA) having different degrees of PDA side chains were synthesized by Michael-type addition polymerization from $N, N^{\prime}$-cystaminebisacrylamide (CBA), 4-amino-I-butanol (ABOL), PDA, and ethylene diamine (EDA) (Scheme 6.2b). All polymers were obtained as a white to slightly yellow brittle material. The PDA side groups are reactive to sulfhydryls and were later on used for post-crosslinking of polyplexes prepared from these polymers by reaction with a difunctional thiol compounds. Addition of crosslinking dithiol reagent to these PAAs having disulfide linkages in their backbone is however not without risk, since in principle these disulfides are also susceptible for nucleophilic attack by these thiols. However, the disulfides moieties of the PDA group 
are more reactive due to the good leaving group property of the 2-thiopyridyl group, making the trans-disulfide-coupling at the PDA group proceeding much faster than in the polymer backbone. Furthermore, nucleophilic attack of thiols to the backbone disulfides can theoretically not disturb the crosslinking reaction, since this side reaction also releases a new thiol that is available for crosslinking. Thus cleavage of the disulfide in the backbone by the dithiol crosslinker will only result in scrambling of the original polymer structure, but finally still results in network formation.
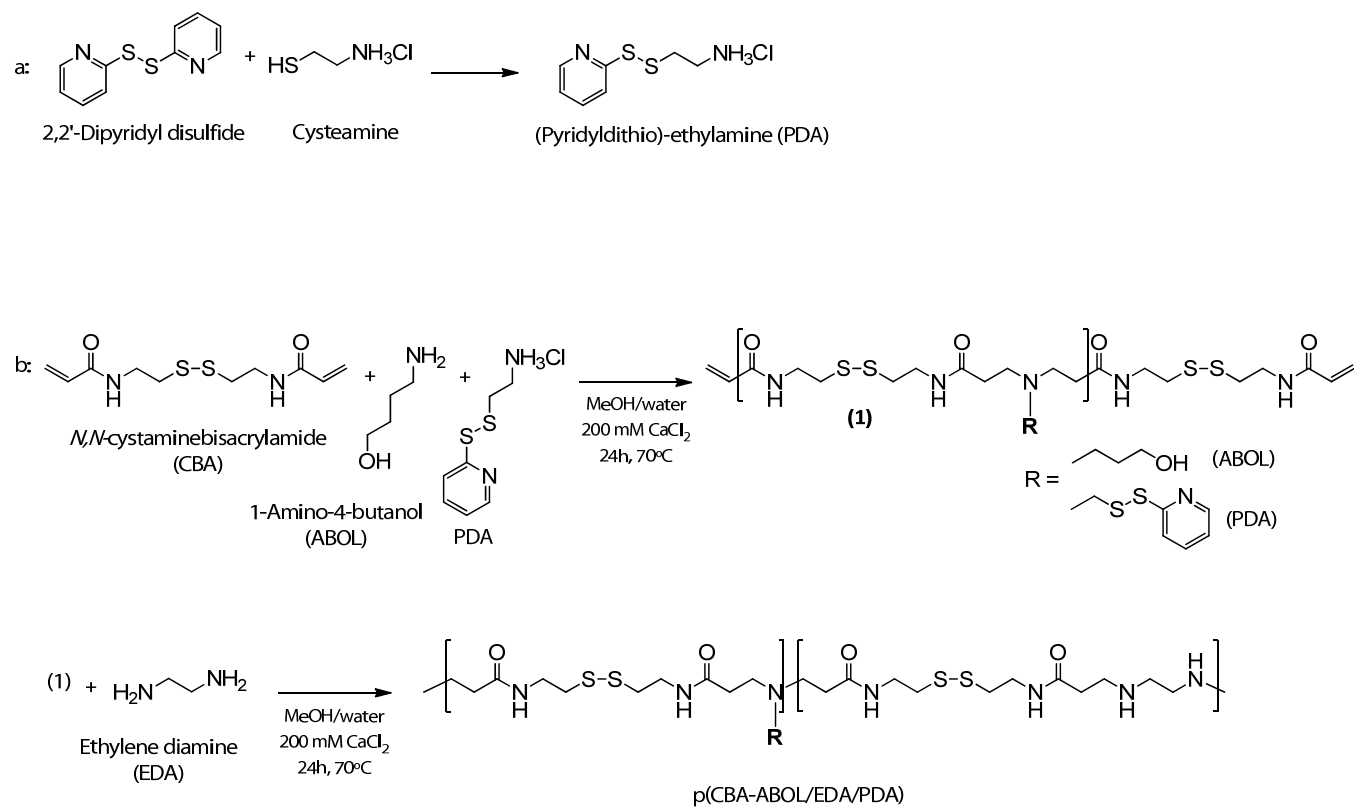

Scheme 6.2: Synthesis of the 2-(pyridyldithio)-ethylamine monomer (PDA) (a) and p(CBA-ABOL/EDA/PDA) copolymers from CBA, ABOL, PDA and EDA (b).

In parallel to the synthesis of the three SS-PAAs, two other non-reducible poly(amido amine)s (CC-PAAs) were synthesized, employing the non-reducible I,6hexamethylenebisacrylamide (HBA) monomer instead of CBA. These polymers are lacking the disulfides in the backbone and served as a control for possible side reactions with thiols. Also these polymers were obtained in good yields as a brittle white to slightly yellow material.

The $\mathrm{ABOL} / \mathrm{EDA}$ ratio in the synthesis of all the polymers was kept constant at its optimal molar ratio $3 / \mathrm{I}$ and the obtained ratio between $\mathrm{ABOL}$ and EDA was determined from the NMR spectra. The obtained composition of the polymers without PDA matched this ratio quite well, but the ABOL/EDA molar ratio in polymers having PDA side groups deviated slightly more from this ideal ratio. It is however not expected that that will play a major role in this study. The final PDA content was determined by NMR

$104 \cdot$ Chapter 6 
(not shown) and colorimetrically by measuring the absorbance of the released 2pyridylthione at $343 \mathrm{~nm}$ after exposure to tenfold excess of mercaptoethanol (Table 6. I) [22]. The results of both measurements were in agreement, but the PDA content in the polymer was significantly lower than in the monomer feed. This is possibly explained by an anchimeric disproportionation by the free base of the PDA monomer under the polymerization conditions, resulting in cystamine and 2,2'-dipyridyl disulfide. This phenomenon was observed before for asymmetric 2-(aryldithio)ethylamines [23-25] and also noticed by others in the synthesis of PDA containing poly(amino ester)s [20] and poly(amino amine)s [26]. The released cystamine may interfere in the polymerization reaction since it has four possible reaction sites in the Michael reaction, resulting in partially branched structures. It was however impossible to verify this by NMR, since the chemical shifts of cystamine peaks are overlapping with peaks of the polymers.

Table 6.1: Synthesis characteristics.

\begin{tabular}{|c|c|c|c|c|}
\hline Polymer $^{\text {a }}$ & $\begin{array}{l}\text { Bisacrylamide } \\
\text { monomer }^{b}\end{array}$ & $\begin{array}{l}\text { Feed composition }{ }^{c} \\
\text { ABOL / EDA / PDA }\end{array}$ & $\begin{array}{l}\text { Obtained composition }^{d} \\
\text { ABOL / EDA / PDA }\end{array}$ & $\begin{array}{l}\text { Intrinsic viscosity } \\
{[\eta](d l / g)^{e}}\end{array}$ \\
\hline SS-PAA-0 & CBA & $75 / 25 / 0$ & $80 / 20 / 0$ & 0.55 \\
\hline SS-PAA-10 & CBA & $56 / 19 / 25$ & $59 / 31 / 10$ & 0.18 \\
\hline SS-PAA-17 & CBA & 45 / 15 / 40 & $65 / 18 / 17$ & 0.15 \\
\hline CC-PAA-0 & HBA & $75 / 25 / 0$ & $77 / 23 / 0$ & 1.17 \\
\hline CC-PAA-10 & HBA & $56 / 19 / 25$ & $73 / 17 / 10$ & 0.53 \\
\hline
\end{tabular}

(a) The number behind the abbreviation represents the molar PDA content of the polymer; (b) Bisacrylamide monomer used in the polymerization: $C B A=N, N$-cystamine bisacrylamide, $H B A=1,6$-hexamethylene bisacrylamide; (c) Stoichiometrical feed ratio of monomers; (d) Determined by ${ }^{1} \mathrm{H} N \mathrm{MR}$ and UV absorbance; (e) Determined in an Ubbelohde micro viscosimeter in $100 \mathrm{mM}$ acetate buffer with $\mathrm{pH} 4.5$.

The relative molecular weights of the polymers were estimated by viscosimetry. From Table 6.I it becomes clear that the presence of PDA sidegroups dramatically reduces the intrinsic viscosity. This observation can be explained by the increased hydrophobicity of the PDA group, resulting in more globular polymer coils and thus a lower viscosity. However, since the difference in intrinsic viscosities with the non-PDAcontaining polymer is rather large, it is reasonable to assume that also the molecular weight of the PDA-containing polymers is lower. The non-reducible polymers also possess consistently higher intrinsic viscosities compared to their reducible analogs. Also here hydrophobic effects may be involved, since the hydrophobicity is higher for two $\mathrm{CH}_{2}$ groups than for the more electronegative disulfide group [27]. However, it cannot be excluded that these polymers have a higher molecular weight than their nonreducible counterparts, which was observed before with similar polymers in literature [28]. 


\subsubsection{Kinetics of crosslinking}

The bifunctional sulfydryl compound bis(2-mercaptoethyl) ether (MEE) (Figure 6.I) was selected as a crosslinker for the polyplexes. Preceding the crosslinking studies with the polyplexes, first the kinetics of the conversion of PDA with MEE in the SS-PAA-IO polymer were investigated at comparable concentrations present during polyplex crosslinking. The release of 2-pyridylthione in time was calculated from the increase in UV absorbance at $343 \mathrm{~nm}$ (Figure 6.2a). The experiment was repeated on siRNA containing polyplexes in the 24/I polymer/siRNA weight ratio with five different MEE concentrations expressed as the percentage of available PDA groups (Figure 6.2b). The 24/I polymer/siRNA weight ratio was selected since this ratio gave the best silencing for $\mathrm{p}\left(\mathrm{CBA}-\mathrm{ABOL}_{75} / \mathrm{EDA}_{25}\right.$ ) without cytotoxicity (chapter 3-5). The rate of PDA conversion on polyplexes was slightly slower than on free polymer, which may be caused lower accessibility of the PDA groups in the polyplex. The maximum conversions were also lower for the polyplexes (around 90\%) as is illustrated by similar conversion kinetics in the overlapping curves for 0.9 and I.o equivalents of MEE in Figure 6.2b, indicating that a part of the PDA groups was inaccessible because of encapsulation inside the polyplex. This also means that at these high MEE concentrations unreacted thiols of MEE are left, which potentially attack disulfides in the backbone of the polymer.
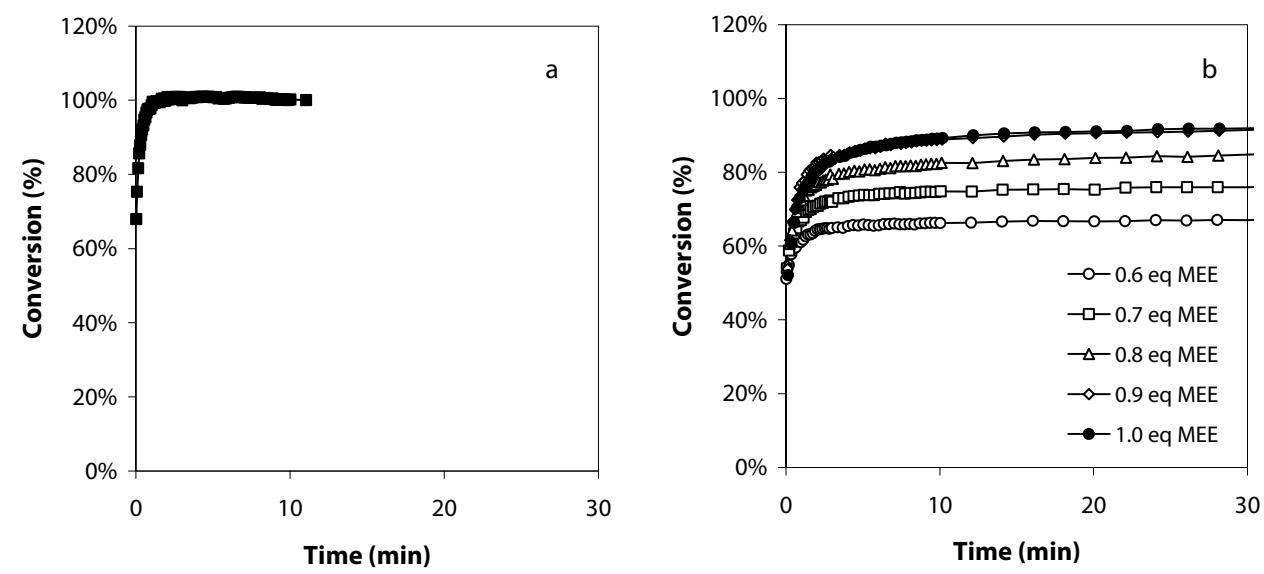

Figure 6.2: PDA substitution of SS-PAA-10 by bis(2-mercaptoethyl) ether (MEE) on free polymer with 2 eq. of MEE (a) and on siRNA polyplexes in the polymer/siRNA weight ratio of $24 / 1$ (b).

\subsubsection{Particle size and $\zeta$-potential}

Before evaluating the stability and biological potential of the crosslinked polyplexes, first the hydrodynamic diameter and surface charge of the polyplexes were studied by DLS. It was observed that the polyplex size did not change after crosslinking and was around 80 and $\mathrm{I} 20 \mathrm{~nm}$ for SS-PAA-IO and SS-PAA-I7, respectively (Figure 6.3a). These values are in accordance with previous results on similar complexes with the

$106 \cdot$ Chapter 6 
parent $\mathrm{p}\left(\mathrm{CBA}-\mathrm{ABOL}_{75} / \mathrm{EDA}_{25}\right)$ polymer without $\mathrm{PDA}$ functionalities as described in chapter 3 and 5. The somewhat larger size of particles of SS-PAA-I7 is very likely originating from the lower charge density of this polymer, because of its lower EDA content, as was also observed for the parent polymer (chapter 3). Also the values for the $\zeta$-potentials, which are between 30 and $40 \mathrm{mV}$ for different degrees of crosslinking, are consistent with similar polymers lacking PDA side groups (Figure 6.3b). These results illustrate that both the incorporation of PDA in the $\mathrm{p}\left(\mathrm{CBA}-\mathrm{ABOL}_{75} / \mathrm{EDA}_{25}\right)$ copolymer as well as crosslinking do not significantly affect the particle size and surface charge. This is in accordance to observations with crosslinking of PLL polyplexes $[3,6]$ and high molecular weight PEI polyplexes [5].
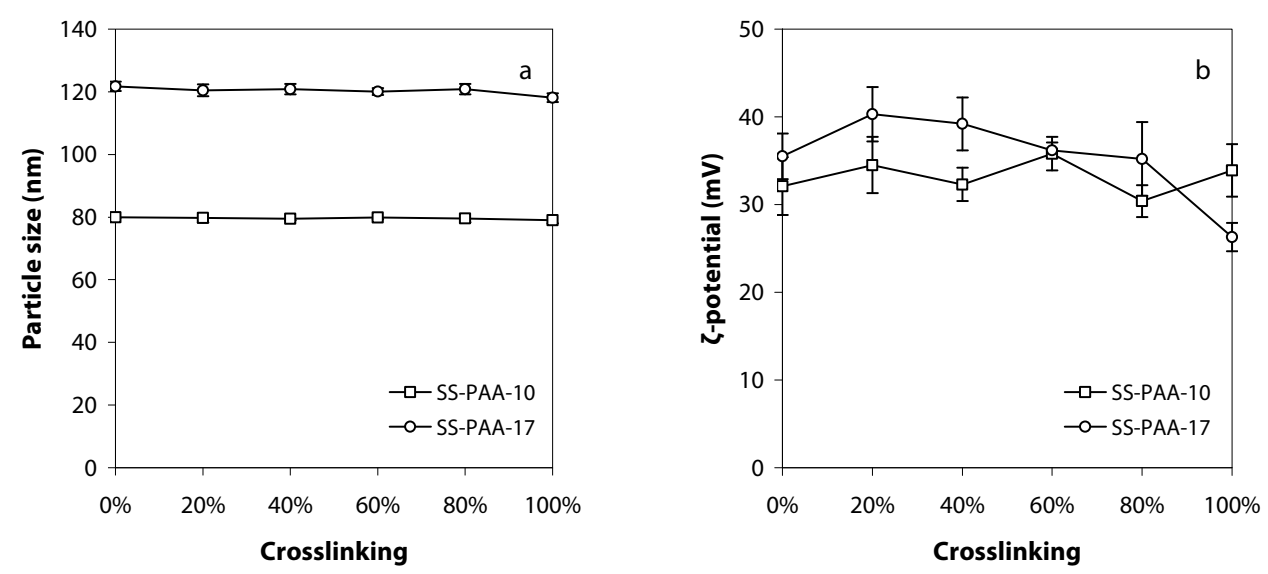

Figure 6.3: Particle properties of polyplexes formed from the reducible PDA containing polymers with siRNA at a polymer/siRNA weight ratio 24/1 measured by dynamic light scattering particle size (a) and $\zeta$-potential (b). Polyplexes were crosslinked with MEE at $\mathrm{pH} 7.4$ and crosslinking degrees are defined as the fraction of available PDA sidegroups that is theoretically involved in the crosslinking reaction.

\subsubsection{Stability of polyplexes in presence of competing polyanions}

It is hypothesized that crosslinking of the complexes contributes to their stability against competing polyanions. Theoretically polyplexes cannot dissociate anymore after crosslinking, which results in embedded siRNA molecules in the polymer network. In order to evaluate the effect of crosslinking on the stability of the polyplexes, we have crosslinked siRNA-containing polyplexes to five different degrees and have incubated these in heparin solutions of different concentrations, expressed as the weight fraction of siRNA. The crosslinking degree is defined as the fraction of available PDA sidegroups that is theoretically involved in the crosslinking reaction. Crosslinked polyplexes with a polymer/siRNA weight ratio of 24/I were loaded on an agarose gel containing ethidium bromide and after running, the gels were illuminated by UV light. Fluorescent spots of 
ethidium/siRNA complexes indicate the presence of uncomplexed siRNA and show at which concentrations of heparin siRNA is released from the polyplexes (Figure 6.4).

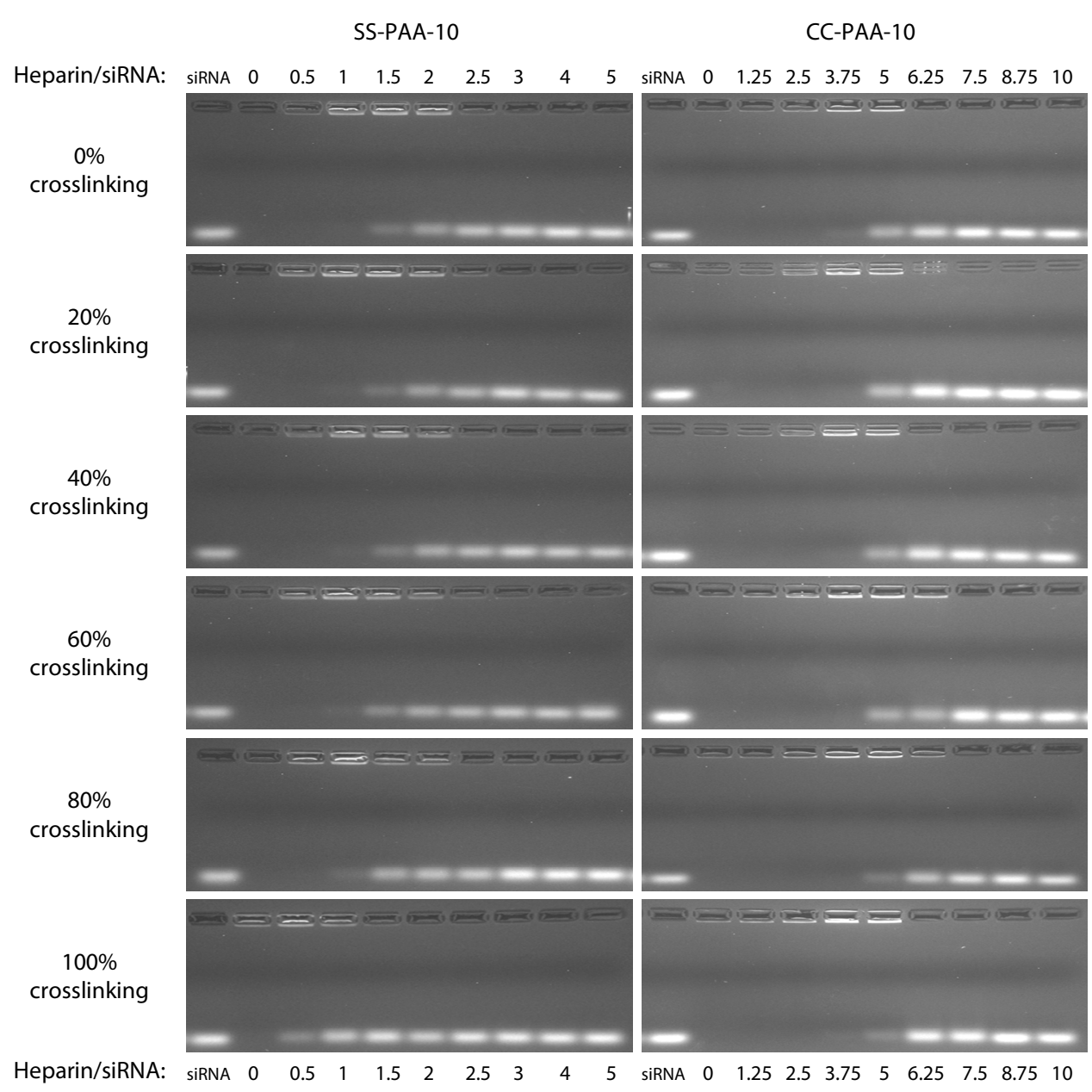

Figure 6.4: Gel electrophoresis pictures of SS-PAA-10 (left) and CC-PAA-10 (right) polyplexes at a polymer/siRNA weight ratio 24/1 in presence of increased heparin ratios. Polyplexes were crosslinked with MEE at $\mathrm{pH} 7.4$ and crosslinking degrees are defined as the fraction of available PDA sidegroups that is theoretically involved in the crosslinking reaction.

The panels in the first row of this Figure 6.4 show that siRNA is released from polyplexes without crosslinking at concentrations from $\mathrm{I} .5$ times excess of heparin from SS-PAA-IO and from 5 times excess from CC-PAA-IO. This indicates that polyplexes from the non-reducible polymer are more stable, which is likely caused by the higher molecular weight of the polymer. Crosslinking of the complexes does not significantly contribute to the stability against heparin as is shown in the next rows. At a crosslinking

$108 \cdot$ Chapter 6 
degree of Iоo\%, SS-PAA-Io polyplexes even become less stable, but CC-PAA-Io polyplexes are not affected. This indicates that the excess of dithiol crosslinker that is used in the preparation of these polyplexes may reduce some of the disulfide linkages in the polymer backbone due to the unavailability of accessible PDA moieties. This cleavage of the polymer main chains may then lead to destabilization of the polyplexes.

It was not clear why the stability of the polyplexes was not significantly increased upon crosslinking. It was hypothesized that the average number of PDA functionalities on the SS-PAA-Io polymer chain was lower than 3, which is the critical lower limit required for network formation. Therefore polyplexes of SS-PAA-I7 were also evaluated for their resistance against heparin before and after crosslinking with 0.4 equivalents of MEE. The MEE concentration was chosen to prevent any reductive side reactions with the polymer backbone to allow for a fair comparison. Figure 6.5 shows the result after gel electrophoresis for polyplexes crosslinked at $\mathrm{pH}$ 7.4. Also for this polymer no increased stability was observed at $40 \%$ crosslinking. Since siRNA is already released from a heparin ratio of I instead of I.5 for SS-PAA-IO, the absolute stability of the SSPAA-I7 polyplexes was even lower. Unfortunately, GPC measurements to determine the absolute molecular weight of the polymers failed, probably due to network formation as a result of released cystamine during the polymerization as described above. Although it was not possible to verify the hypothesis, it remains strongly questioned if the absolute number of PDA per chain is indeed too low, since DLS measurements on the free polymer do indicate network formation (vide infra). It could be that despite crosslinking the pores in the polyplex network are still large enough for siRNA and heparin to diffuse in and out. Although no evidence for this diffusion was found in literature, the absence of published results about stabilizing siRNA containing polyplexes by crosslinking may be an indication that this is more difficult than might be expected on beforehand.

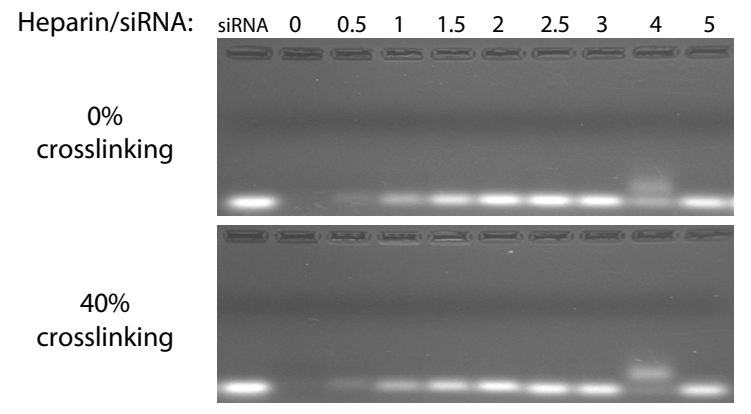

Figure 6.5: Gel electrophoresis pictures of SS-PDA-17 in presence of increased heparin ratios. Polyplexes were crosslinked with MEE at $\mathrm{pH} 7.4$ and crosslinking degrees are defined as the fraction of available PDA sidegroups that is theoretically involved in the crosslinking reaction. 


\subsubsection{In vitro gene silencing}

We have tested siRNA polyplexes of the PDA polymers for their potential of silencing luciferase in Hı299 cells, which stably express this enzyme. In Figure 6.6a-c, the silencing potential of uncrosslinked SS-PAA-IO and SS-PAA-I7 polyplexes was compared with their non-PDA-containing analog (SS-PAA-o) at five different polymer/siRNA weight ratios.
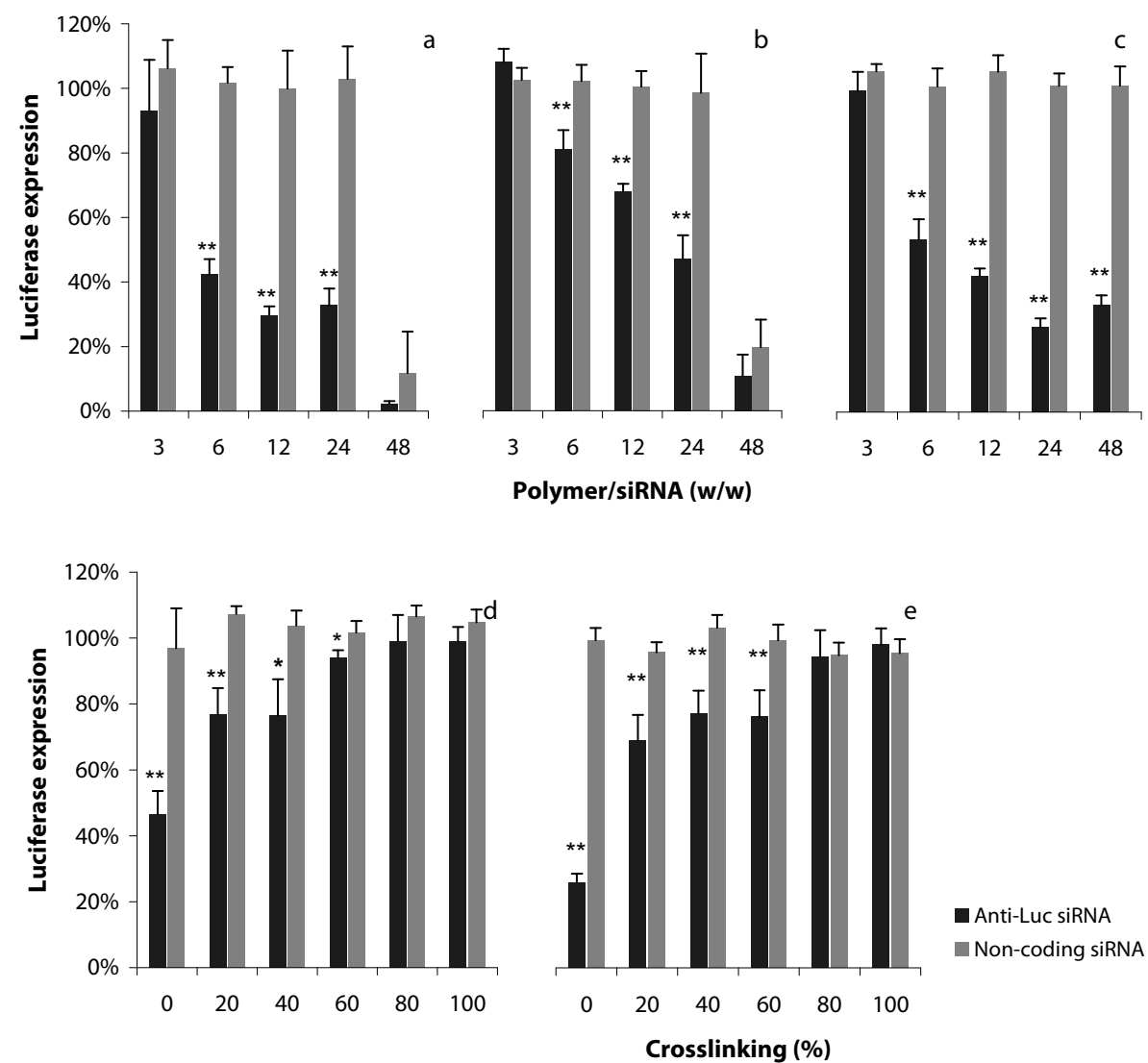

Figure 6.6: Luciferase expression of $\mathrm{H} 1299$ Fluct cells 48 hours after transfection with anti-luciferase siRNA (black) and non-coding control siRNA (grey) with SS-PAA-0 (a), SS-PAA-10 (b), SS-PAA-17 (c), SS-PAA-10 at polymer/siRNA weight ratio 24/1 crosslinked in different degrees (d) and SS-PAA-17 at polymer/siRNA weight ratio 24/1 crosslinked in different degrees (e). Crosslinking degrees are defined as the fraction of available PDA side groups that is theoretically involved in the crosslinking reaction. Each bar value represents the mean \pm SD of $n=3,4$ or 5 . For statistical analysis of differences between anti-luciferase and non-coding siRNA an unpaired Student's t-test was used $\left({ }^{*} p<0.05 ;{ }^{* *} p<0.01\right)$.

The obtained knockdown for SS-PAA-Io polyplexes is somewhat lower than for SSPAA-o, which may be explained by the relatively high EDA content in this polymer. In previous studies (chapter 3 and 4 ) we learned that high EDA contents have an adverse

$110 \cdot$ Chapter 6 
effect on the silencing potential. SS-PAA-I7 polyplexes on the other hand show silencing results that are comparable to their non-PDA containing counterparts. Even the toxicity of this carrier is reduced, as is clear from the 100\% luciferase expression after treatment with non-coding siRNA for the polymer/siRNA weight ratio of 48/I. This reduced cytoxicity is believed to be a result of the lower charge density of this polymer as a result of a lower EDA content than the other polymers. It is not likely that the reduced cytotoxicity originates from the presence of PDA groups, since Zugates et al. found an increased cytotoxicity for PDA containing polymers [20].

The effect of crosslinking of the polyplexes on the silencing properties was evaluated with SS-PDA-Io and SS-PDA-I7 polyplexes with a polymer/siRNA weight ratio of 24/I with 5 different crosslinking degrees (Figure $6.6 \mathrm{~d}$ and e). Unfortunately, the silencing diminished for increased crosslinking degrees as was observed for both SSPAA-IO and SS-PAA-I7. At polyplexes with crosslinking degrees of $80 \%$ and higher, no significant silencing was observed at all.

It was unexpected that crosslinking of our formulations negatively influenced the silencing properties, since previous results have shown that the presence of disulfides in the main chain of our polymers always contributed to increase the transfection efficiency [29-30]. However, decreased transfection efficiencies were also observed in a few other studies after reducible polyplex crosslinking [3, 7, I2]. These authors attributed these observations to a shortage of glutathione to reduce all the crosslinks within the timeframe of the experiment. Neu et al. also hypothesized that extracellular reduction on the cell membrane could decelerate uptake. In order to verify whether HI299 cells show reduction potential, these cells were incubated with Ellman's reagent. However, no yellow coloration was observed, indicating that no reaction with disulfide bonds is taking place at the cell membrane surface (data not shown). Another possible reason for decreased silencing after crosslinking may be the destabilization of the complexes as a result of attacked disulfides in the backbone by the MEE crosslinker. For validation of this hypothesis, $N, N^{\prime}$-hexamethylene bisacrylamide polymers, which do not contain disulfides in the backbone, were also applied in silencing experiments. Figure 6.7a and b show the luciferase expression of Hi299 cells after treatment with polyplexes in different polymer/siRNA weight ratios of CC-PAA-o and CC-PAA-IO, respectively. It is clear from these figures that polymers without disulfides are considerably more toxic than there disulfide-containing counterparts, as was expected because of their inability of rapid reductive degradation. Furthermore, the cytotoxicity of CC-PAA-Io polyplexes seems to be somewhat lower than the non-PDA containing CC-PAA-o polyplexes, matching the observations on the SS-PAA polymers (Figure 6.6a and c) and likely originating from the lower EDA content. For crosslinking of CC-PAAIo polyplexes the polymer/siRNA ratio 6/I was selected, since the 24/I ratio proved to be 
highly toxic. Figure $6.7 \mathrm{c}$ shows that there is no difference in silencing potential for the different crosslinking degrees and learns that crosslinking of polyplexes prepared from this non-reducible polymer at the used weight ratio, does neither influence the silencing properties. This is an indication that the reduced silencing that is observed after crosslinking of SS-PAA polyplexes can be a result of polyplex destabilization due to polymer backbone degradation. However, the heparin displacement experiments have shown that this is only likely for the highest crosslinking degree. For the lower crosslinking degrees reduced silencing may be caused by delayed siRNA release
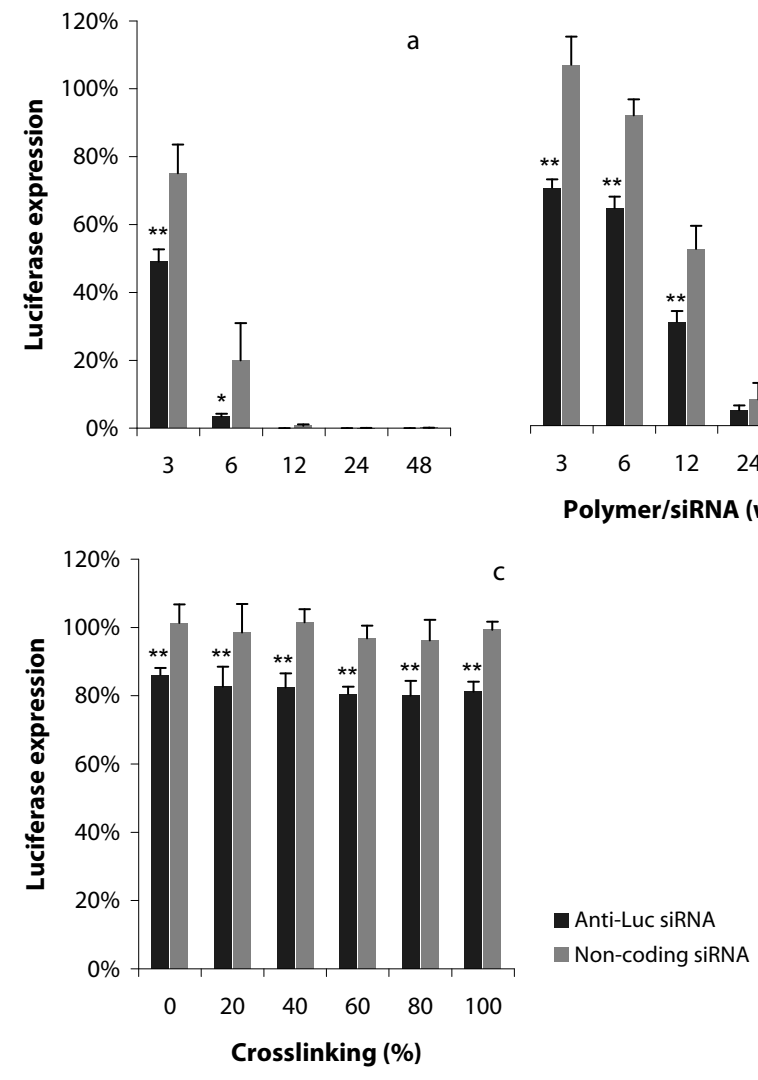

Figure 6.7: Luciferase expression of $\mathrm{H} 1299$ Fluct cells 48 hours after transfection with anti-luciferase siRNA (black) and non-coding control siRNA (grey) with CC-PAA-0 (a), CC-PAA-10 (b) and CC-PAA-10 at polymer/siRNA weight ratio $6 / 1$ crosslinked in different degrees (c). Crosslinking degrees are defined as the fraction of available PDA sidegroups that is theoretically involved in the crosslinking reaction. Each bar value represents the mean \pm SD of $n=3,4$ or 5 . For statistical analysis of differences between anti-luciferase and non-coding siRNA an unpaired Student's t-test was used $\left({ }^{*} p<0.05 ;{ }^{* *} p<0.01\right)$. compared

to

uncrosslinked polyplexes since more disulfides need to be reduced before silencing can start. The assembling of some free polymer onto the complex during crosslinking may amplify this effect, although larger particle sizes as a result of extra polymer were not observed in DLS experiments. Such delay is, logically, more apparent at a higher polymer excesses as were used in the 24/I polymer/siRNA weight ratio for crosslinked polyplexes of SS-PAA-IO and SS-PAA-I7, but was not further investigated in this study. 


\subsubsection{Network formation}

The results so far did not show improved stability for crosslinked polyplexes. For the SS-PAA copolymers even a decrease in silencing efficiency was observed after crosslinking. An important question arises from these results, namely is crosslinking of the polyplexes really happening?' The fact that a reaction between MEE and the PDA functionalities is occurring is beyond the question, since this was proven by the UV measurements as described earlier, but it is not clear whether this indeed results in network formation. A possibility to clarify this point is by molecular weight measurements. Therefore intrinsic viscosity measurements were performed on partially 'crosslinked' solutions of SS-PAA-Io and CC-PAA-Io.

Table 6. 2: Intrinsic viscosities after crosslinking of polymer solutions. Crosslinking degrees are defined as the fraction of available PDA sidegroups that is theoretically involved in the crosslinking reaction.

\begin{tabular}{|c|c|c|c|c|}
\hline \multirow{3}{*}{ Polymer } & \multirow{3}{*}{ XL degree } & \multicolumn{3}{|c|}{ Intrinsic viscosity [n] (dl/g) } \\
\hline & & MEE & MEE & DMP \\
\hline & & \multicolumn{3}{|c|}{ post oxidation $I_{2}$} \\
\hline \multirow{4}{*}{ SS-PAA-10 } & $0 \%$ & 0.18 & & 0.18 \\
\hline & $20 \%$ & 0.17 & 0.14 & 0.17 \\
\hline & $40 \%$ & 0.15 & 0.12 & 0.17 \\
\hline & $60 \%$ & 0.13 & & 0.12 \\
\hline \multirow{4}{*}{ CC-PAA-10 } & $0 \%$ & 0.53 & & 0.53 \\
\hline & $20 \%$ & 0.50 & 0.45 & 0.52 \\
\hline & $40 \%$ & 0.46 & 0.39 & 0.47 \\
\hline & $60 \%$ & 0.44 & & 0.42 \\
\hline
\end{tabular}

Crosslinked polymers are expected to give an increase in intrinsic viscosity, which was confirmed in PEI crosslinking experiments [II, 3I]. However, for our polymers the contrary was found and only a decrease in viscosity was observed after treatment of the polymers with the crosslinking reagent MEE (Table 6. 2). Therefore it seems that MEE is not forming a network structure with the SS-PAAs. A possible reason may be that it only acts as a disulfide cleavage reagent, similar to the action of DTT, which forms a stable cyclic disulfide upon reduction of disulfides. In that case the cleavage of the S-S bond of the PDA side group and the eventual formation of a thiol side group could explain the small decrease in intrinsic viscosity. Although there is some evidence in the literature for the formation of stable seven membered rings of MEE [32-33], a post oxidation treatment to couple possibly formed free thiols did not result in increased viscosities, refuting the occurrence of this side reaction (Table 6. 2). Also 'crosslinking' with 2,3dimercapto-I-propanol (DMP), another dithiol did not result in increased viscosities. Cyclization of DMP is not likely as in this case a four membered ring would be formed with a high ring strain. Apparently, another phenomenon is occurring simultaneously, which is distorting these measurements. 
Hydrophobic disulfide-containing poly(amido amine)s are known to spontaneously self assemble into nanoparticles, even in the absence of polynucleotides [34]. Since SSPAAs with a high fraction of PDA groups are poorly soluble at $\mathrm{pH} 7.4$ or higher, indicating that these polymers are rather hydrophobic, it is possible that also these polymers spontaneously form nanoparticles. To examine if spontaneous particle formation takes place, SS-PAA-Io polymer solutions at various crosslinking degrees were measured by dynamic light scattering at $\mathrm{pH}$ 7.4. Figure 6.8 shows that particles are indeed formed with sizes independent of the crosslinking degree. Also the absolute intensity of the measured signal, expressed as the count rate, remained stable irrespective of the crosslinking degree. Protonation of the polymer increases both the hydrophilicity as well as polymer chain repulsion and is therefore expected to lead to dissociation of these particles. When the $\mathrm{pH}$ of these particle solutions was lowered to 4.5 the size of the uncrosslinked particles dramatically increased and virtually no particles were detected. Crosslinked particles, however, showed only a minor increase in particle size, reasonably caused by swelling due to the increased charge repulsions, and the decrease in count rates was significantly lower for crosslinked particles. This indicates that the spontaneously formed particle structure is fixed after crosslinking, keeping the particles in tact after protonation. These measurements explain the absence of an increased intrinsic viscosity and corroborate that nanoparticles of PDA containing polymers are indeed crosslinked by addition of MEE.
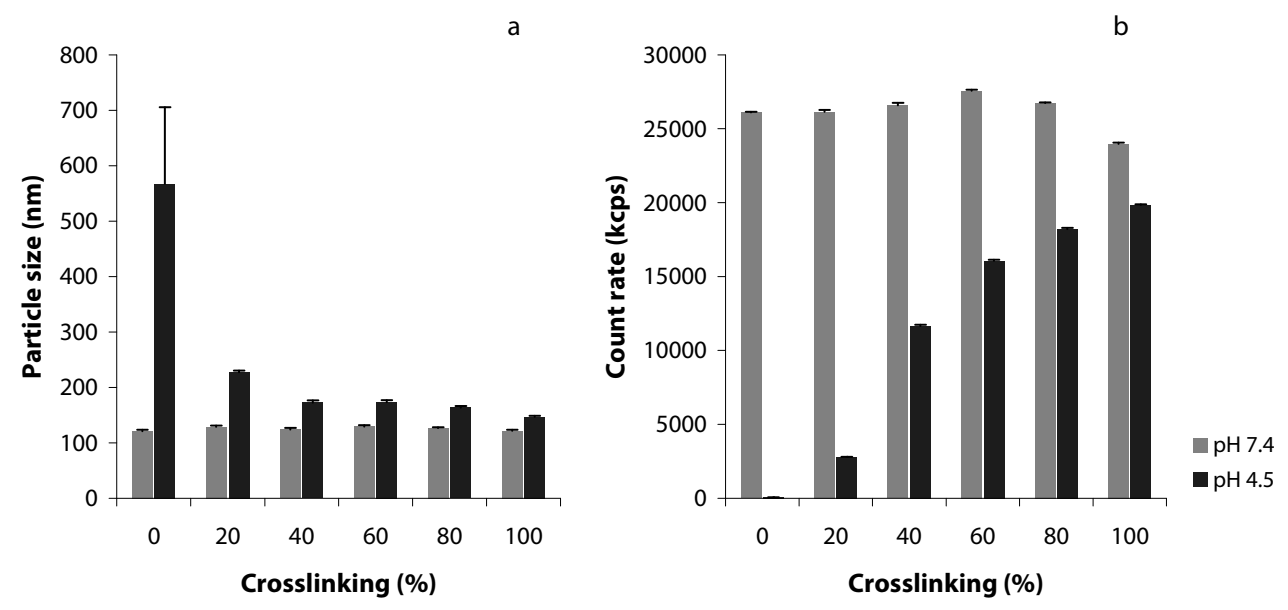

Figure 6.8: Particle sizes (a) and count rates (b) determined by DLS at pH 7.4 (light grey) and pH 4.5 (dark grey) from spontaneously formed particles without siRNA from SS-PAA-10 at $150 \mu \mathrm{g} / \mathrm{ml}$ crosslinked with MEE. Crosslinking degrees are defined as the fraction of available PDA sidegroups that is theoretically involved in the crosslinking reaction. 


\subsection{Conclusions}

PDA sidegroups could be easily introduced in disulfide-and non-disulfidecontaining poly(amido amine)s for siRNA delivery. These sidegroups could be employed for reversible crosslinking of polyplexes, using the bifunctional thiol molecule bis(2mercaptoethyl) ether (MEE). Network formation in the nanoparticles was approved in particle dissociation experiments. However, the expected increase in stability of polyplexes against the competing polyanion heparin was not observed. It is hypothesized that the pores in the polymer network of the polyplexes are still large enough for siRNA and heparin to diffuse in and out. The crosslinked polyplexes showed lower gene silencing capacity. For the maximal crosslinking degree, this could be attributed to complex destabilization, but for lower crosslinking degrees a delay in gene silencing could play an important role since for the crosslinked polyplexes more disulfides need to be reduced to obtain siRNA release.

\subsection{Acknowledgement}

Thanks to Leonie Voskamp for developing PDA-containing poly(amido amine)s.

\subsection{References}

I. $\quad$ Boussif, O., et al., $A$ Versatile Vector for Gene and Oligonucleotide Transfer into Cells in Culture and in-Vivo - Polyethylenimine. Proceedings of the National Academy of Sciences of the United States of America, I995. 92(I6): p. 7297-730I.

2. Oupicky, D., et al., Steric stabilization of poly-L-lysine/DNA complexes by the covalent attachment of semitelechelic poly [ $\mathrm{N}-(2-$

hydroxypropyl)methacrylamide]. Bioconjugate Chemistry, 2000. II(4): p. 492501 .

3. Oupicky, D., R.C. Carlisle, and L.W. Seymour, Triggered intracellular activation of disulfide crosslinked polyelectrolyte gene delivery complexes with extended systemic circulation in vivo. Gene Therapy, 2001. 8(9): p. 713-724.

4. Miyata, K., et al., Block catiomer polyplexes with regulated densities of charge and disulfide cross-linking directed to enhance gene expression. Journal of The American Chemical Society, 2004. 126(8): p. 2355-2361.

5. $\quad$ Neu, M., et al., Stabilized nanocarriers for plasmids based upon cross-linked poly(ethylene imine). Biomacromolecules, 2006. 7(12): p. 3428-3438.

6. Trubetskoy, V.S., et al., Caged DNA does not aggregate in high ionic strength solutions. Bioconjugate Chemistry, I999. Io(4): p. 624-628. 
7. Neu, M., et al., Crosslinked nanocarriers based upon poly(ethylene imine) for systemic plasmid delivery: In vitro characterization and in vivo studies in mice. Journal Of Controlled Release, 2007. II8(3): p. 370-380.

8. Manickam, D.S. and D. Oupicky, Polyplex gene delivery modulated by redox potential gradients. Journal Of Drug Targeting, 2006. I4(8): p. 519-526.

9. Gosselin, M.A., W.J. Guo, and R.J. Lee, Efficient gene transfer using reversibly cross-linked low molecular weight polyethylenimine. Bioconjugate Chemistry, 200I. I2(6): p. 989-994.

Io. Wang, Y.X., P. Chen, and J.C. Shen, The development and characterization of a glutathione-sensitive cross-linked polyethylenimine gene vector. Biomaterials, 2006. 27(30): p. 5292-5298.

II. $\quad$ Peng, Q., et al., Influence of Disulfide Density and Molecular Weight on Disulfide Cross-Linked Polyethylenimine as Gene Vectors. Bioconjugate Chemistry, 2009. 20(2): p. 340-346.

I2. Lee, D., et al., Thiolated chitosan/DNA nanocomplexes exhibit enhanced and sustained gene delivery. Pharmaceutical Research, 2007. 24(I): p. 157-I67.

I3. Gosselin, M.A., W.J. Guo, and R.J. Lee, Incorporation of reversibly cross-linked polyplexes into LPDII vectors for gene delivery. Bioconjugate Chemistry, 2002. I3(5): p. I044-I053.

I4. Matsumoto, S., et al., Environment-Responsive Block Copolymer Micelles with a Disulfide Cross-Linked Core for Enhanced siRNA Delivery.

Biomacromolecules, 2009. Io(I): p. II9-I27.

I5. Kakizawa, Y., A. Harada, and K. Kataoka, Glutathione-sensitive stabilization of block copolymer micelles composed of antisense DNA and thiolated poly(ethylene glycol)-block-poly(L-lysine): A potential carrier for systemic delivery of antisense DNA. Biomacromolecules, 200I. 2(2): p. 49I-497.

I6. Lee, H., et al., Target-specific intracellular delivery of siRNA using degradable hyaluronic acid nanogels. Journal Of Controlled Release, 2007. II9(2): p. 245252.

I7. Hermanson, G.T., Bioconjugate techniques. I996, San Diego: Academic Press. xxv, $785 \mathrm{p}$.

I8. Garnett, M.C., et al., Sterically stabilized self-assembling reversibly cross-linked polyelectrolyte complexes with nucleic acids for environmental and medical applications. Biochemical Society Transactions, 2009. 37(4): p. 713-716.

I9. Ranucci, E., et al., Poly(amidoamine) Conjugates with Disulfide-Linked Cholesterol Pendants Self-Assembling into Redox-Sensitive Nanoparticles. Biomacromolecules, 2008. 9(Io): p. 2693-2704.

20. Zugates, G.T., et al., Synthesis of poly(beta-amino ester)s with thiol-reactive side chains for DNA delivery. Journal of the American Chemical Society, 2006. I28(39): p. I2726-I2734.

2I. Zintchenko, A., L.J. van der Aa, and J.F.J. Engbersen, Improved Synthesis Strategy of Poly(amidoamine)s for Biomedical Applications: Catalysis by "Green" Biocompatible Earth Alkaline Metal Salts. Macromolecular Rapid Communications, 20I0: p. Accepted manuscript.

22. Grassett, D.R. and J.F. Murray, Determination of sulfhydryl groups with 2, 2'-or 4, 4'-dithiodipyridine. Archives of Biochemistry and Biophysics, I967. II9(I-3): p. $4 \mathrm{I}-\&$.

$116 \cdot$ Chapter 6 
23. Field, L., et al., Organic Disulfides and Related Substances. IV. Thiolsulfonates and Disulfides Containing 2-Aminoethyl Moieties. Journal Of The American Chemical Society, I96I. 83(2I): p. 44I4-44I7.

24. Bellas, M., D.L. Tuleen, and L. Field, Organic Disulfides and Related Substances. XXII. Substituted benzyl 2-(n-decylamino)ethyl disulfide hydrochlorides. A possible neighboring-group effect involving sulfur. Journal Of Organic Chemistry, I967. 32(8): p. 259I-2595.

25. Field, L., T.F. Parsons, and D.E. Pearson, Organic Disulfides and Related Substances. XVIII. Synthesis and Disproportionation of 2(Aryldithio)ethylamine Hydrochlorides. Journal Of Organic Chemistry, I966. 3I(II): p. 3550-3555.

26. Ranucci, E., et al., Poly(amidoamine)s with 2-dithiopyridine side substituents as intermediates to peptide-polymer conjugates. Macromolecular Rapid Communications, 2007. 28(II): p. I243-I250.

27. Lin, C. and J.F.J. Engbersen, The role of the disulfide group in disulfide-based polymeric gene carriers. Expert Opinion on Drug Delivery, 2009. 6(4): p. 42I439.

28. Chen, J., C. Wu, and D. Oupicky, Bioreducible Hyperbranched Poly(amido amine)s for Gene Delivery. Biomacromolecules, 2009. Io(Io): p. 292 I-2927.

29. Lin, C., et al., Linear poly(amido amine)s with secondary and tertiary amino groups and variable amounts of disulfide linkages: Synthesis and in vitro gene transfer properties. Journal of Controlled Release, 2006. II6(2): p. I30-I37.

30. Piest, M., et al., Novel poly(amido amine)s with bioreducible disulfide linkages in their diamino-units: Structure effects and in vitro gene transfer properties. Journal of Controlled Release, 2008. I30(I): p. 38-45.

31. Thomas, M., et al., Cross-linked small polyethylenimines: While still nontoxic, deliver DNA efficiently to mammalian cells in vitro and in vivo. Pharmaceutical Research, 2005. 22(3): p. 373-380.

32. Goodrow, M.H. and W.K. Musker, Synthesis of Medium Ring Disulfides by Titrimetry; An Improvement on High Dilution Techniques. SynthesisStuttgart, I98I(6): p. 457-459.

33. Affleck, J.G. and G. Dougherty, The preparation and relative reactivities of many-membered cyclic disulfides. The Journal of Organic Chemistry, I950. I5(4): p. 865-868.

34. Piest, M. and J.F.J. Engbersen, Effects of charge density and hydrophobicity of poly(amido amine)s for non-viral gene delivery. Journal Of Controlled Release, 2010. I48(I): p. 83-90. 


\section{8 - Chapter 6}




\title{
Chapter
}

\author{
Introducing pyridyl disulfides in \\ p(CBA-ABOL/EDA) - post-PEGylation \\ of siRNA containing polyplexes
}




\begin{abstract}
In this study the post-PEGylation of pyridyl disulfide (PDA) functionalized SSPAA/siRNA polyplexes using thiol-functionalized PEG (PEG-SH) was investigated. By a disulfide exchange reaction between PEG-SH and PDA on the polyplexes, PEG was conjugated to the polyplexes via a bioreducible linkage. The PEGylation effectively decreased the surface potential of the polyplexes without influencing the polyplex size. PEGylation of the polyplexes contributed dramatically to the colloidal stability of the polyplexes in physiological salt solutions and provided particles that were stable for more than one month, although stability against the competing polyanion heparin was not apparent. Moreover, nucleolytic degradation of siRNA was also prevented by PEGylation. The post-PEGylation reaction with PEG-SH 2000 is critically dependent on the applied ratio of PEG-SH/PDA. An optimum in polyplex stability was found when 40 - 60 mol\% of PEG-SH was added with respect to the number of PDA groups present in the polyplex. For the higher molecular weight PEG-SH 50oo, the applied PEG-SH / PDA ratio was found to be of minor influence. The gene silencing of $20-30 \%$ obtained by siRNA polyplexes with up to $50 \mathrm{wt} \%$ of PEG 5000 was still reasonable in view of the reduction of their surface charges.
\end{abstract}

\title{
7.1 Introduction
}

In the recent decade, polymeric gene delivery and especially siRNA delivery gained increased interest because of its high potential to treat diseases at their source [I]. Many successes were booked with in vitro studies, but the development of potent gene carriers in vivo stayed far behind. To develop gene carriers for in vivo applications, a high colloidal stability of the polyplexes is required. Especially the systemic application of highly cationic charged polyplexes is difficult, since injection in the bloodstream exposes the complexes to high ionic strengths and anionically charged proteins, which are both notoriously inducing aggregation and destabilization by non-specific interactions [I-3]. Furthermore, protection against nucleases, which are omnipresent in the extracellular environment, is essential and stealth properties are required to protect the delivery particles from phagocytosis by the immune system [I, 3]. The presence of cationic charge in a polymeric vector is one of the most important properties to form self-assembled nanoparticles with nucleic acids, but a high cationic charge density is conflicting with the requirement that for in vivo circulation neutral particles are required. However, shielding of the cationic charge of the complexes by coating with hydrophilic polymers like poly(ethylene glycol) (PEG) [2, 4-6] and poly[ $N-(2-$ hydroxypropyl)methacrylamide] (PHPMA) [7] or proteins [8] proved to be a successful strategy to reduce the interactions with the above mentioned substances effectively.

$120 \cdot$ Chapter 7 
PEGylation (coating with PEG) is by far the most applied technique for charge shielding and was investigated thoroughly to find optimal PEG chain lengths and PEGylation degrees. For PEI- $g$-PEG/DNA complexes, a PEG molecular weight of at least $5 \mathrm{~kg} / \mathrm{mol}$ was needed for a significant decrease of the surface charge. To obtain stability in physiological salt solution and a low cytotoxicity a PEG substitution is required with at least six PEG blocks (5 kg/mol) [2, 9]. Transfection efficiency was however dramatically decreased as a result of these modifications. Similar research employing PEI- $g$ PEG/siRNA yielded only a small decrease in surface charge and even a reduction of polyanion (heparin) stability for PEG molecular weights $\geq 2 \mathrm{~kg} / \mathrm{mol}$, but generated improved in vitro silencing as a result of the less stable character of the polyplexes [Iо]. These results were confirmed in a similar study with oligonucleotides, but in this case increased polyanion (heparin) stability was found by using PEI-g-PEG polyplexes with lower PEI molecular weight $(2 \mathrm{~kg} / \mathrm{mol})$ [II-I2]. The latter system also gave the highest in vitro transfection compared to standard system with $25 \mathrm{~kg} / \mathrm{mol} \mathrm{PEI}$ [I3]. Later it was claimed that PEI (25 kg/mol) grafted with long ( $\geq 20 \mathrm{~kg} / \mathrm{mol}$ ) and few (I or 2) PEG chains leads to phase separation of the PEI/DNA core from the PEG corona, resulting in better DNA condensation, protection and an increased in vivo circulation of the polyplexes [I4].

Basically three different approaches can be distinguished to introduce PEG onto polyplexes: conjugation of PEG to the nucleic acid [15-16], synthesizing PEG-cationic copolymers (pre-PEGylation) [4, IO-II, I7-I8] and coupling PEG to the preformed polyplexes (post-PEGylation) [5-6, I4, I9]. Of course there are good arguments in favor and against the different strategies. PEG chains introduced by pre-PEGylation of the nucleotide or the cationic polymer may impede the formation of stable nanoparticles by steric interactions of the neutral PEG chains and reduce the electrostatic interactions needed for self-assembly of negatively charged nucleic acids and positively charged polymer. On the other hand, this lower stability of the polyplexes may help the intracellular release of the nucleotides for a better expression, provided that they survive the transport to the target tissue [Io]. The pre-PEGylation approach imposes new syntheses for every subtle variation, is associated with loss of material during work up procedures and finally, if delicate targeting ligands are present on PEG, it limits the choice in conjugation chemistry. In case of post-PEGylation the possibility for separation of unreacted reagents is frequently limited to aqueous techniques like dialysis and the conjugation chemistry is restricted to aqueous conditions, although this is not necessarily problematic. Physical interactions between PEG and the polyplex can also be utilized to realize post-PEGylation [6]. On the other hand, the drawbacks of prePEGylation are overcome by post-PEGylation, which makes this strategy an excellent approach for PEGylation of cationic polyplexes. In addition, since interference in 
polyplex formation does not play a role in this case, the post-PEGylation approach offers easy possibilities to vary the PEG block length for tuning the polyplex stability.

Where the nucleic acids are normally released from the polyplex by interactions with cytosolic proteins or RNA [20-2I] and/or the existence of an increased redox potential inside the cell [22-23], the improved extracellular protection and colloidal stability that is obtained by PEGylation is automatically extended to the intracellular environment and therefore may inhibit the release of the nucleic acid contents from the polyplex. This limitation is independent of the chosen PEGylation strategy, but was solved creatively by introducing degradable linkers in the PEG chain. Acid labile or reduction sensitive linkers are favorable since they are triggered by intracellular stimuli. Hydrazone [24-26], acetal [27] and orthoester [28] linkages are stable at physiological $\mathrm{pH}$, but are rapidly hydrolyzed during endosomal acidification and were applied successfully for $\mathrm{pH}$ reversible polyplex shielding. Disulfides are sensitive for the increased reduction potential of cell membranes [29-30] and in the endolysosomal pathway [3I-32] and disulfide groups become further reduced in the cytosol due to the increased glutathione concentrations [33]. PEG that was coupled via disulfide bonds to P[Asp(DET) [34], PEI [14] and PLL [35] showed successful PEG detaching from their polyplexes after exposure to reducible circumstances, resulting in improved gene delivery.

In this study we have developed PEGylated siRNA containing polyplexes composed of the successful $\mathrm{p}\left(\mathrm{CBA}-\mathrm{ABOL}_{75} / \mathrm{EDA}_{25}\right)$ polymer. We have chosen for a post-PEGylation strategy because of the above mentioned advantages and have used for this purpose the pyridyl disulfide (PDA) containing $\mathrm{p}\left(\mathrm{CBA}-\mathrm{ABOL}_{75} / \mathrm{EDA}_{25}\right)$ polymers, synthesized in the previous chapter. The PDA groups on the polyplexes of these polymers are PEGylated by thiol functionalized PEGs in a facile way by forming bioreducible disulfide linkages resulting in a reversible charge shielding. We show that the PEGylation degree and PEG chain length can be easily varied without the synthesis of many different polymers, allowing the evaluation of these parameters on polyplex size, surface potential, salt stability, heparin competition, nuclease protection and gene silencing.

\subsection{Materials and methods}

\subsubsection{Materials}

Toluene was dried over sodium wire followed by distillation. Dichloromethane and methanol were purified by drying over calcium hydride and distillated before use. The other chemicals and reference materials, methoxy poly(ethylene glycol) $(2000 \mathrm{~g} / \mathrm{mol}$,

122 - Chapter 7 
Aldrich and $5000 \mathrm{~g} / \mathrm{mol}$, Fluka), mesyl chloride (Aldrich), trioctylamine (Fluka), pyridine (extra dry over molecular sieve, Acros), potassium thioacetate (Fluka), sodium thiomethoxide (Aldrich), 5,5'-dithiobis(2-nitrobenzoic acid) (DTNB, Ellman's reagent, Aldrich), L-cysteine (Fluka), heparin (Celsus Laboratories Inc) and Lipofectamine 2000 (Invitrogen) were purchased in the highest purity and used without further purification. For culturing the Hi299 Fluct cells, RPMI I640 medium (Lonza) completed with $2 \%$ (v/v) PennStrepp (Lonza), I\% (v/v) glutamine (Lonza) and Io\% (v/v) fetal bovine serum (Lonza) was used. Negative control siRNA was purchased from Qiagen, anti-luciferase siRNA was kindly supplied by the University of Utrecht. Luciferase assay reagent was obtained from Promega.

\subsubsection{Synthesis of the reducible $p(C B A-A B O L / E D A / P D A)$ copolymers (SS-PAA)}

A detailed description of the synthesis of the reducible p(CBA-ABOL/EDA/PDA) copolymers used in this study can be found in chapter 6 of this thesis.

\subsubsection{Synthesis of thiol functionalized poly(ethylene glycol)s (PEG-SH)}

Thiol functionalized PEGs (PEG-SH) with molecular weights of 2000 and 5000 $\mathrm{g} / \mathrm{mol}$ were synthesized from methoxy PEG in a three step synthesis as described below.

\section{PEG-mesylate}

The hydroxyl group of methoxy PEG was activated by mesylation according to a slightly modified procedure as was published Elbert et al. [36]. In a typical example Io.o $\mathrm{g}(5 \mathrm{mmol}$, I eq) of methoxy PEG $(2000 \mathrm{~g} / \mathrm{mol})$ was dried twice in an azeotropical distillation of $70 \mathrm{ml}$ of dry toluene. After the second distillation step, the PEG was dissolved in $20 \mathrm{ml}$ of dry dichloromethane followed by the addition of $6.6 \mathrm{ml}$ (15 mmol, 3 eq) of trioctylamine. Subsequently, the solution was cooled in an ice bath and $\mathrm{I.72} g$ of mesyl chloride was added dropwisely. The reaction was proceeded overnight at room temperature under a nitrogen atmosphere, followed by precipitation in diethyl ether. PEG-mesylate was finally collected as a white powder by filtration and dried under vacuum. Yield: $83 \%$. ${ }^{\mathrm{H}} \mathrm{H}$ NMR $\left(\mathrm{CDCl}_{3}\right) \delta(\mathrm{ppm}): 3.08\left(\mathrm{~s}, 3 \mathrm{H}, \mathrm{OSO}_{2} \mathrm{CH}_{3}\right) ; 3.37(\mathrm{~s}, 3 \mathrm{H}$, $\left.\mathrm{CH}_{3} \mathrm{OCH}_{2}\right) ; 3.40\left(\mathrm{t}, 2 \mathrm{H}, \mathrm{CH}_{3} \mathrm{OCH}_{2}\right) ; 3.52-3.90$ (m, $\left.176 \mathrm{H}, \mathrm{PEG}\right) ; 4.38$ (t, $2 \mathrm{H}$, $\mathrm{CH}_{2} \mathrm{CH}_{2} \mathrm{OSO}_{2} \mathrm{CH}_{3}$ ). 


\section{PEG-thioacetate}

In the second step the mesylate group was converted into a thioacetate according to a modified literature procedure [37]. Typically, $3.0 \mathrm{~g}$ (I.5 mmol, I eq) of PEG-mesylate $(2000 \mathrm{~g} / \mathrm{mol})$ was dissolved in Io $\mathrm{ml}$ of dry pyridine and separately $2.23 \mathrm{~g}$ (19.5 mmol, I3 eq) of potassium thioacetate was dissolved in $28 \mathrm{ml}$ of a $2 / \mathrm{I}(\mathrm{v} / \mathrm{v})$ mixture of dry pyridine/methanol. The PEG-mesylate solution and $2.6 \mathrm{ml}$ of trioctylamine were then added to the potassium thioacetate solution and the reaction mixture was stirred overnight at room temperature in a nitrogen atmosphere. All solvents were evaporated, the residue was dissolved in $\mathrm{Io} \mathrm{ml}$ of brine and extracted four times with dichloromethane. The organic phase was dried over magnesium sulfate, concentrated and precipitated twice in diethyl ether. PEG-thioacetate was finally collected as a white powder by filtration and dried under vacuum. Yield: $78 \% .{ }^{\mathrm{r}} \mathrm{H} \mathrm{NMR}\left(\mathrm{CDCl}_{3}\right) \delta$ (ppm): 2.33 (s, $\left.{ }_{3} \mathrm{H}, \mathrm{CH}_{2} \mathrm{SCOCH}_{3}\right) ; 3.08$ (t, $\left.3 \mathrm{H}, \mathrm{CH}_{2} \mathrm{SCOCH}_{3}\right) ; 3.37$ (s, $\left.3 \mathrm{H}, \mathrm{CH}_{3} \mathrm{OCH}_{2}\right) ; 3.4 \mathrm{O}(\mathrm{t}, 2 \mathrm{H}$, $\left.\mathrm{CH}_{3} \mathrm{OCH}_{2}\right) ; 3.52-3.90$ (m, I76H, PEG).

\section{PEG-thiol (PEG-SH)}

In the last step the thioacetate was deprotected to yield PEG-SH [38]. Typically, 2.3 $\mathrm{g}$ ( $\mathrm{I} .2 \mathrm{mmol}$, I eq) of PEG-thioacetate $(2000 \mathrm{~g} / \mathrm{mol})$ was put in a reaction flask and dissolved in Io $\mathrm{ml}$ methanol under a nitrogen atmosphere. 8I $\mathrm{mg}$ (1.2 mmol, Ieq) of sodium thiomethoxide dissolved in $\mathrm{m} \mathrm{ml}$ of methanol was added to the PEG solution and stirred for 30 minutes at room temperature. Then the reaction mixture was poured into $20 \mathrm{ml}$ of o.I $\mathrm{M}$ aqueous hydrochloric acid and extracted by dichloromethane. The organic layer was washed with brine and all solvents were removed by rotational evaporation. To remove the last impurities, PEG was dissolved in $40 \mathrm{ml}$ demineralized water containing $0.35 \mathrm{~g}$ DTT $(2.3 \mathrm{mmol}, 2 \mathrm{eq})$ to reduce eventually oxidized thiols and dialyzed by ultrafiltration with a molecular weight cutoff of $1000 \mathrm{~g} / \mathrm{mol}$. PEG-SH was finally obtained as a white fluffy powder by lyophilization. Yield: $85 \%$. ${ }^{\mathrm{H}} \mathrm{HMR}\left(\mathrm{CDCl}_{3}\right)$ $\delta$ (ppm): I.59 (t, $\left.\mathrm{IH}, \mathrm{CH}_{2} \mathrm{CH}_{2} S H\right) ; 2.68\left(\mathrm{q}, 2 \mathrm{H}, \mathrm{CH}_{2} \mathrm{CH}_{2} \mathrm{SH}\right) ; 3.37$ (s, $\left.3 \mathrm{H}, \mathrm{CH}_{3} \mathrm{OCH}_{2}\right) ; 3.40$ (t, $2 \mathrm{H}, \mathrm{CH}_{3} \mathrm{OCH}$ ); $3.52-3.90$ (m, I76H, PEG).

\subsubsection{Ellman test}

The thiol content of the synthesized PEG-SH was measured in an Ellman assay. PEG-SH was dissolved in phosphate buffer (IOo $\mathrm{mM}, \mathrm{pH}$ 7.4) with a thiol concentration of $0.2 \mathrm{mM}$ (assuming 100\% conversion) and mixed with $0.3 \mathrm{mM}$ DTNB (Ellman's reagent) solution in a I/I volumetric ratio. After I hour incubation at room temperature, the absorbance at a wavelength of 4I2 nm was measured on a Cary 300 Bio UV-Visible 
spectrophotometer. The absorbance was converted to thiol concentrations using a calibration curve recorded with L-cysteine.

\subsubsection{Polyplex preparation and PEGylation}

Polyplexes were prepared in HEPES buffered glucose, unless stated otherwise (HBG: $20 \mathrm{mM}$ HEPES, $\mathrm{pH} 7.4,5 \mathrm{wt} \%$ glucose) in a polymer/siRNA weight ratio of 24/r. The polymer solution was added to the siRNA solution in a volume ratio of $4 / \mathrm{r}$, followed by $5 \mathrm{~s}$ vortexing and $30 \mathrm{~min}$ incubation at room temperature. Subsequently, the polyplexes were PEGylated by mixing a polyplex solution with a PEG solution (in pure water) of appropriate concentration in a volume ratio of $\mathrm{IO} / \mathrm{I}$, followed by incubation for I hour at room temperature. UnPEGylated polyplexes were mixed with plain water in the same volume ratio of Io/I.

\subsubsection{Dynamic light scattering (DLS)}

All polyplexes were prepared and crosslinked as described above in a $20 \mathrm{mM}$ HEPES buffer $\mathrm{pH} 7.4$ without additional salt or glucose at a polymer/siRNA weight ratio of 24/I and a final siRNA concentration of $6.25 \mu \mathrm{g} / \mathrm{ml}$. The hydrodynamic diameter and the $\zeta$-potential were measured by dynamic light scattering (DLS) on a Zetasizer Nano ZS (Malvern Instruments) at $25^{\circ} \mathrm{C}$. Subsequently, $50 \mu \mathrm{l}$ of a concentrated salt solution (3.15 $\mathrm{M} \mathrm{NaCl}$ and $0.4 \mathrm{wt} \% \mathrm{NaN}_{3}$ ) were added to I $\mathrm{ml}$ of polyplex solution, to finally result in a physiological salt concentration. The solutions were stored at $37^{\circ} \mathrm{C}$ and the hydrodynamic diameters of the polyplexes were measured by DLS at regular time intervals.

\subsubsection{Stability of polyplexes against heparin}

Polyplexes containing $6.25 \mu \mathrm{g} / \mathrm{ml}$ siRNA were prepared and PEGylated by PEG 2000 as described above in the polymer/siRNA weight ratio 24/I. $33 \mu$ samples of these polyplex solution were mixed with $3 \mu \mathrm{l}$ of heparin solutions with different concentrations, expressed as a heparin/siRNA weight ratio. After 30 minutes incubation with heparin, $25 \mu \mathrm{l}$ of polyplex solution was mixed with $4 \mu \mathrm{l}$ of loading buffer and loaded on a $4.0 \mathrm{wt} \%$ agarose gel containing $0.25 \mu \mathrm{M}$ ethidium bromide. Electrophoresis was performed for $60 \mathrm{~min}$ at $90 \mathrm{~V}$ in a TAE running buffer $(40 \mathrm{mM}$ tris(hydroxymethyl)aminomethane, $20 \mathrm{mM}$ acetic acid, Io mM EDTA, pH 8,o) supplemented with $0.25 \mu \mathrm{M}$ ethidium bromide. After electrophoresis, pictures were taken on a Biorad Gel Doc 2000 under UV illumination and analyzed using Biorad Multi Analyst software version I.I. 


\subsubsection{Serum nuclease protection}

Polyplexes were prepared in HBG in a 24/I polymer/siRNA weight ratio having a final siRNA concentration of $44 \mu \mathrm{g} / \mathrm{ml}$ as described above. After 30 minutes of incubation, the polyplexes were PEGylated by adding $75 \mu \mathrm{l}$ of polyplex solution to $7.5 \mu \mathrm{l}$ of PEG solution and incubated at room temperature for another hour. $75 \mu \mathrm{l}$ of polyplex solution was added to $75 \mu \mathrm{l}$ of a $20 \%(\mathrm{v} / \mathrm{v}) \mathrm{FBS}$ in PBS (IomM phosphate, $140 \mathrm{mM} \mathrm{NaCl}$, $\mathrm{pH} 7.4$ ) and incubated at $37^{\circ} \mathrm{C}$. At six time points (o, I, 2, 4, 8 and $24 \mathrm{~h}$ ), $20 \mu \mathrm{l}$ aliquots were taken, mixed with $5 \mu$ stop solution ( $250 \mathrm{mM} \mathrm{NaCl}, 25 \mathrm{mM}$ EDTA, $85 \mathrm{mM}$ SDS, I6 $\mathrm{mM}$ DTT) to deactivate nucleases and to dissociate the polyplexes and stored at $-20^{\circ} \mathrm{C}$. After the last aliquot, samples were defrosted, mixed with $4 \mu$ loading buffer, loaded on a $4 \mathrm{wt} \%$ agarose gel and electrophoresed for $60 \mathrm{~min}$ at $90 \mathrm{~V}$ in a TAE running buffer $(40$ $\mathrm{mM}$ tris(hydroxymethyl)aminomethane, $20 \mathrm{mM}$ acetic acid, Io mM EDTA, $\mathrm{pH} \mathrm{8,o)}$ supplemented with $0.25 \mu \mathrm{M}$ ethidium bromide. After electrophoresis, pictures were taken on a Biorad Gel Doc 2000 under UV illumination and band intensities were finally determined using ImageJ software version I.4og. The experiment was conducted in duplo.

\subsubsection{In vitro gene silencing}

Knockdown efficiency was determined by silencing luciferase expression in $\mathrm{NCl}-$ Hi299 cells, stably expressing firefly luciferase. Knockdown and cell viability were evaluated in two parallel sessions, using anti-luciferase and non-coding siRNA, respectively. Cells were seeded in 96 well plates with a density of 8000 cells per well. After $24 \mathrm{~h}$ incubation at $37^{\circ} \mathrm{C}$ in a humidified atmosphere containing $5 \% \mathrm{CO}_{2}$, medium was replaced with Iooul fresh RPMI I640 supplemented with Io\% FBS. Polyplexes containing $25 \mu \mathrm{g} / \mathrm{ml}$ siRNA at were prepared at a polymer/siRNA weight ratio 24/r and PEGylated as described above. Lipofectamine 2000 was used as a reference and complexes were prepared according to the manufacturer's protocol. Polyplexes $(22 \mu \mathrm{l}$ per well) were added to the cells in quinto after I hour incubation with fresh medium, resulting in a final siRNA concentration of $264 \mathrm{nM}$. After 48 hours of transfection, polyplex medium was discarded, the cells were lysed in a freeze/thaw cycle and $50 \mu 1$ of the cell lysate was mixed with $50 \mu \mathrm{l}$ luciferase assay reagent containing the substrate luciferin. After $100-220$ seconds (in this timeframe the emitted light is constant - data not shown) the luciferase activity was determined by measuring the luminescence at $25^{\circ} \mathrm{C}$ for 4 seconds on a PerkinElmer 1420 Victor $^{3}$ plate reader. Luciferase activity of untreated cells was defined as $100 \%$ expression.

$126 \cdot$ Chapter 7 


\subsection{Results and discussion}

\subsubsection{Polymer synthesis and characterization}

Thiol functionalized poly(ethylene glycol)s (PEG-SH) were synthesized in a three step synthesis from methoxy PEGs with an average molecular weight of 2000 and 5000 $\mathrm{g} / \mathrm{mol}$ (Scheme 7.I). In the first step, the hydroxyl group was activated with mesyl chloride, which was substituted by a thioacetate in step two. In the final step the thioacetate was deprotected resulting in PEG-SH. The total conversion from hydroxyl to thiol was determined by Ellman's reagent and proved to be Ioo\% for both PEGs.

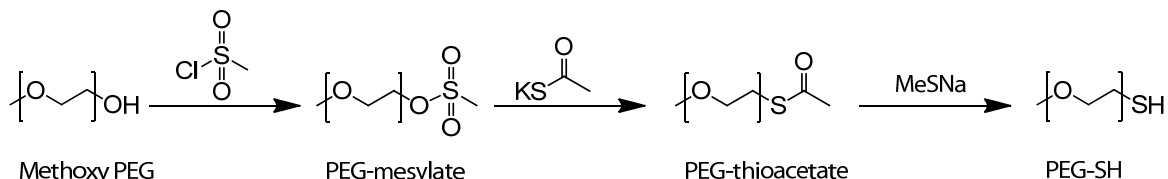

Scheme 7.1: Synthesis of PEG-SH from methoxy PEG.

Two PDA containing $\mathrm{p}\left(\mathrm{CBA}-\mathrm{ABOL}_{75} / \mathrm{EDA}_{25}\right)$ polymers were used in this chapter (Scheme 7.2), containing Io and $\mathrm{I7}$ mol\% of PDA functionalities in the polymer chain, which are named SS-PAA-Io and SS-PAA-I7, respectively. The synthesis of these polymers is described in chapter 6 and for more details about the synthesis and characterization, the reader is referred to that corresponding chapter.

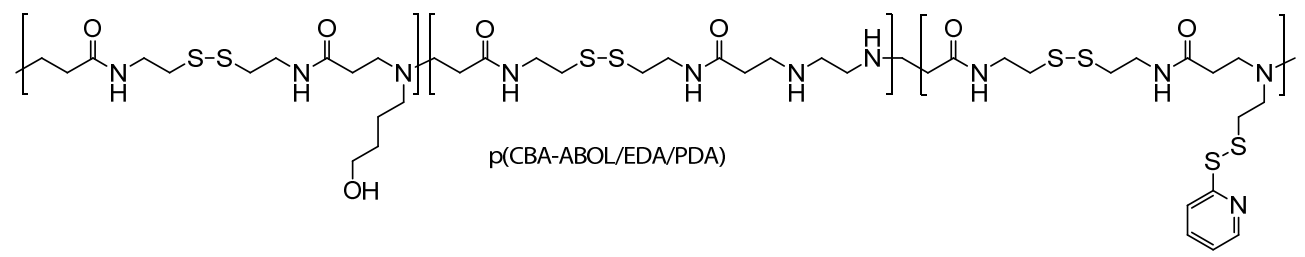

Scheme 7.2: General structure of the used PDA containing p(CBA-ABOL/EDA/PDA) copolymers.

\subsubsection{Polyplex formation and properties}

Polyplexes were prepared at 24/I polymer/siRNA weight ratio and subsequently submitted to the PEGylation reaction with PEG-SH. The 24/I polymer/siRNA weight ratio was selected since this ratio gave the best silencing for $\mathrm{p}\left(\mathrm{CBA}-\mathrm{ABOL}_{75} / \mathrm{EDA}_{25}\right)$ without cytotoxicity (chapter 3-5). The degree of PEGylation of the polymers is defined as the weight percentage of PEG with respect to the weight of cationic polymer and is shown in Table 7.I. Both SS-PAA-Io (containing Io mol\% of PDA units) and SS-PAA-I7 
(containing I7 mol\% of PDA units) were used for PEGylation with PEG-SH 2000 to investigate the influence of the degree of PEGylation as function of the available amount of PDA groups on the polyplex. It should be noted that polyplexes from SSPAA-I7 can be conjugated with almost twice as much PEG as SS-PAA-Io, because of the higher molar ratio of PDA moieties in its polymer chain. Effects of the variation of the molecular weight of the PEG chain were studied only with SS-PAA-I7. Polyplexes of this polymer were PEGylated by both PEG-SH 2000 and PEG-SH 5000.

Table 7.1: Relation between the molar PEG-SH/PDA feed ratio and their corresponding PEG contents expressed in weight percentages with respect to PAA.

\begin{tabular}{llll}
\hline \multirow{2}{*}{$\begin{array}{l}\text { Molar PEG-SH / PDA } \\
\text { feed ratio }\end{array}$} & \multicolumn{3}{c}{ PEG content (PEG/PAA) in wt\% } \\
\cline { 2 - 4 } & $\begin{array}{l}\text { SS-PAA-10 } \\
\text { PEG 2000 }\end{array}$ & $\begin{array}{l}\text { SS-PAA-17 } \\
\text { PEG 2000 }\end{array}$ & $\begin{array}{l}\text { SS-PAA-17 } \\
\text { PEG 5000 }\end{array}$ \\
\hline 0 & $0 \mathrm{wt} \%$ & $0 \mathrm{wt} \%$ & $0 \mathrm{wt} \%$ \\
0.2 & $7 \mathrm{wt} \%$ & $11 \mathrm{wt} \%$ & $29 \mathrm{wt} \%$ \\
0.4 & $13 \mathrm{wt} \%$ & $23 \mathrm{wt} \%$ & $57 \mathrm{wt} \%$ \\
0.6 & $20 \mathrm{wt} \%$ & $34 \mathrm{wt} \%$ & $86 \mathrm{wt} \%$ \\
0.8 & $26 \mathrm{wt} \%$ & $46 \mathrm{wt} \%$ & $114 \mathrm{wt} \%$ \\
1.0 & $33 \mathrm{wt} \%$ & $57 \mathrm{wt} \%$ & $143 \mathrm{wt} \%$ \\
\hline
\end{tabular}

Polyplexes were prepared in $20 \mathrm{mM}$ HEPES buffer $\mathrm{pH} 7.4$ and post-PEGylated by adding concentrated PEG-SH solutions. After PEGylation the hydrodynamic diameter and $\zeta$-potential of the complexes were measured by dynamic light scattering (DLS) and plotted as a function of the PEG weight content in Figure 7.I. Polyplexes of SS-PAA-IO are a little smaller than their counterparts of SS-PAA-I7, which is explained by a higher charge density of SS-PAA-Io due to the relatively higher EDA content. Furthermore, the size seems to be rather unaffected by the conjugation of the polyplexes with PEG-SH. Only a very small decrease is observed after PEGylation with PEG 2000, whereas PEGylation with PEG 5000 slightly increases the polyplex size.

A more meaningful property of PEGylated complexes is, however, the reduction of their $\zeta$-potential. As is shown in Figure 7.Ib the $\zeta$-potential is decreasing significantly with increasing degree of PEGylation. It is worth mentioning that the decrease is independent of the applied PEG-SH/PDA ratio, when the absolute amount of ethylene oxide units (i.e. the weight percentage of PEG) is kept constant. This can be concluded from the curves of PEG 2000 PEGylated polyplexes of SS-PAA-Io and SS-PAA-I7 in Figure 7.Ib showing exactly the same decrease. At the PEG-SH/PDA feed ratio I.o (33 wt\% PEG content) of SS-PAA-Io (i.e. all of the PDA groups are theoretically participating in the PEGylation reaction), the $\zeta$-potential is only reduced to $20 \mathrm{mV}$, which may be insufficient for efficient charge shielding. With SS-PAA-I7 a higher charge reduction is possible, since the density of PDA functionalities in the polymer chain is higher and hence more PEG chains can be conjugated onto the polyplex. A

128 - Chapter 7 
charge reduction below Io $\mathrm{mV}$ is obtained at maximum PEGylation of polyplexes from this polymer, which is expected to be sufficient. Higher PEG weight contents can be introduced when PEG-SH 5000 is used in the post-PEGylation. Polyplexes with a minimum $\zeta$-potential of approximately $5 \mathrm{mV}$ were obtained with a PEG content of 86 $w t \%$. Higher PEG content did not further reduce the $\zeta$-potential, indicating that at this PEGylation degree the polyplex surface is sufficiently covered for maximal charge shielding. Finally, using the same weight percentages of PEG, PEG 5000 seems to be more efficient in shielding the cationic surface charge, since the $\zeta$-potential of polyplexes with $29 \mathrm{wt} \%$ PEG is lower for the PEG 5000 polyplexes than for the PEG 2000 polyplexes with PEG weight contents in the same range (23-34 wt\%).
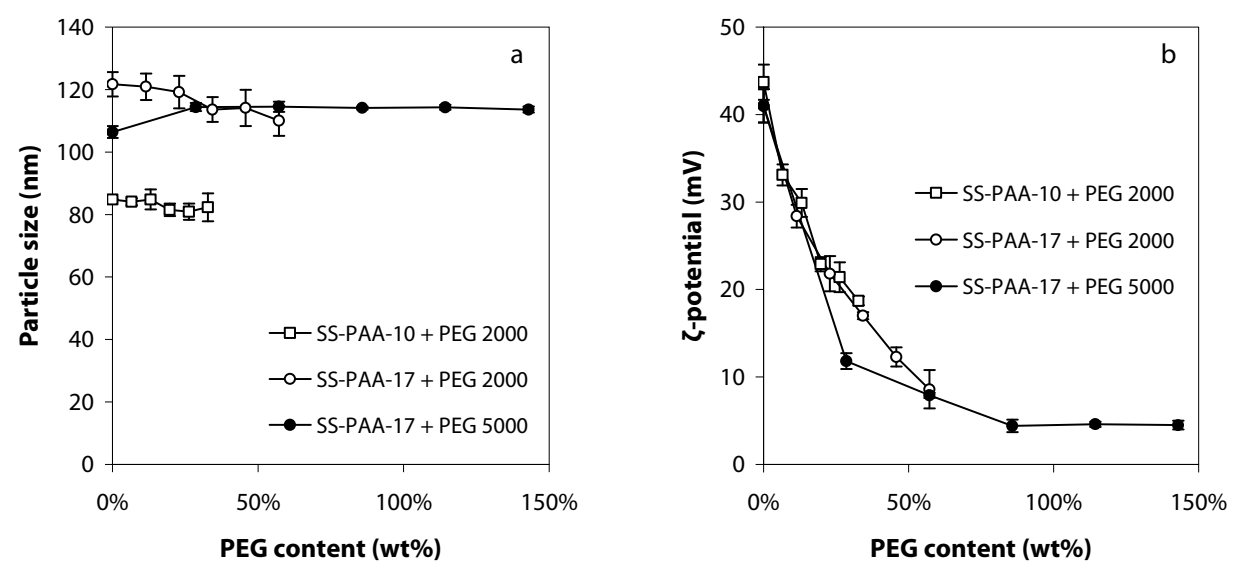

Figure 7.1: Polyplex size (a) and $\zeta$-potential (b) as a function of the PEG content (wt\%) of the PEGylated polyplexes at 24/1 SS-PAA/siRNA weight ratio of $24 / 1$ as measured by DLS.

\subsubsection{Polyplex stability at physiological salt solutions}

To validate if the PEGylation indeed prevents aggregation under physiological conditions, PEGylated polyplexes were incubated in a physiological salt solution at $37^{\circ} \mathrm{C}$ (Figure 7.2) and their sizes were measured at regular time intervals. It is clear that particles without any PEG coating immediately aggregate, resulting in polyplex sizes greater than Iooo $\mathrm{nm}$ within 30 minutes. Polyplexes of SS-PAA-Io with only $7 \mathrm{wt} \%$ PEG show after a small initial growth only a gradual increase in particle size during the first 2 days to ca. $400 \mathrm{~nm}$ (Figure 7.2a). However, polyplexes with higher PEG contents are only stable for approximately I day and start to grow rapidly afterwards. Remarkably, these polyplexes treated with higher PEG/PDA ratios show the lowest stability. Although a higher PEG content results in a higher reduction of the surface charge, the stability of the complex is apparently affected by PEG-SH treatment at higher PEG/PDA 


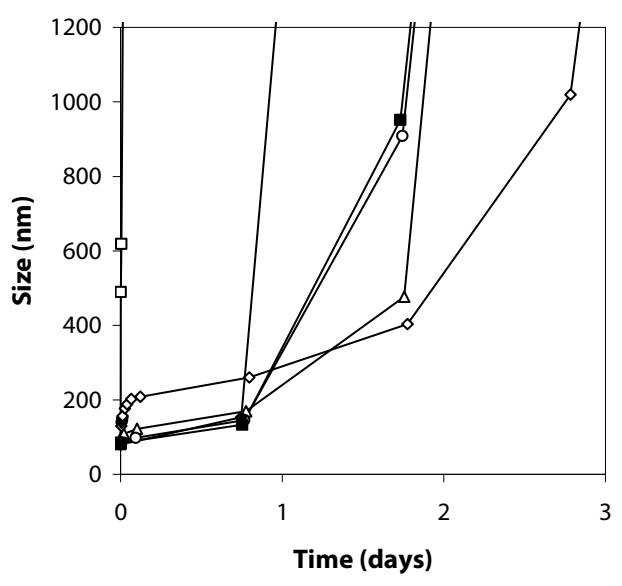

$\square-0 \mathrm{wt} \%$ PEG $\neg 7$ wt $\%$ PEG $\triangle-13$ wt $\%$ PEG -20 wt $\%$ PEG $\rightarrow-26 \mathrm{wt} \%$ PEG $\rightarrow 33$ wt $\%$ PEG

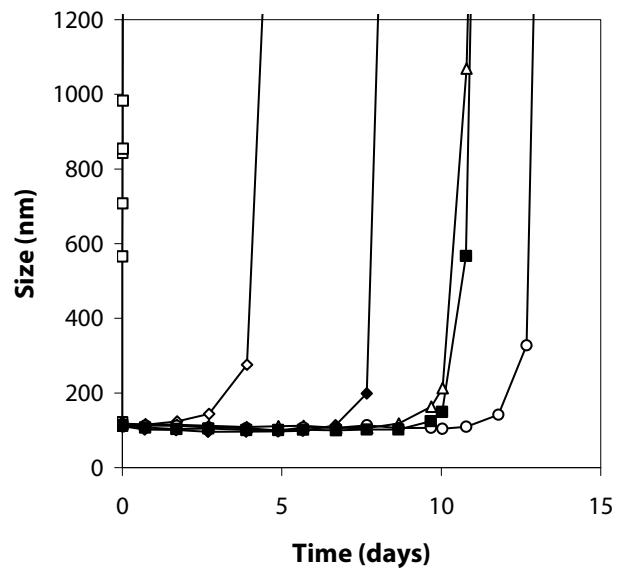

b

$\square-0 \mathrm{wt} \%$ PEG

$\neg 11$ wt $\%$ PEG

$\rightarrow 23 \mathrm{wt} \%$ PEG

- $34 \mathrm{wt} \%$ PEG

$\rightarrow-46 w t \%$ PEG

$\rightarrow 57 \mathrm{wt} \%$ PEG

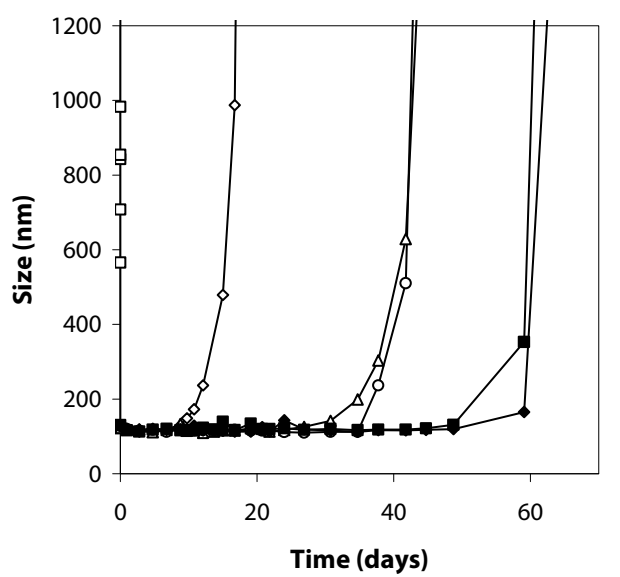

C

$\rightarrow-0 \mathrm{wt} \%$ PEG

$\neg-29$ wt $\%$ PEG

$\triangle-57$ wt $\%$ PEG

$-0-86 \mathrm{wt} \%$ PEG

$\rightarrow-114 \mathrm{wt} \%$ PEG

$\rightarrow 143$ wt $\%$ PEG

Figure 7.2: Particle sizes of the PEGylated polyplexes in a physiological salt solution at $37^{\circ} \mathrm{C}$ of SS-PAA-10 + PEG 2000 (a), SSPAA-17 + PEG 2000 (b), and SS-PAA-17 + PEG 5000 (c). ratios. A reasonable explanation can be that at these higher PEG/PDA ratios a side reaction occurs between PEG-SH and the disulfide groups in the polymer backbone. When PEG-SH couples to a disulfide in the backbone, the polymer chain is cleaved and a polymer fragment with a new thiol endgroup is released, that can subsequently react with a disulfide bond of a PDA functionality. This process results in higher branched and shorter polymer chains and both factors may have a negative effect on the stability of the polyplexes. It has been demonstrated for PEI that a shorter polymer chain length and higher branching have an adverse effect on the formation of stable polyplexes [39]. Moreover, it may be possible that the resulting small cationic polymer fragments coupled to PEG chains, do not have sufficient affinity with the complex anymore, because of the masked cationic charge. Less cationic polymer keeps than associated with the polyplex, resulting also in a

130 - Chapter 7 
decreased protection. SS-PAA-I7 polyplexes PEGylated with PEG 2000 proved to be much more stable than their SS-PAA-Io counterparts (Figure 7.2b). Polyplexes that contain more than II wt\% PEG are stable for at least one week and the longest stability of almost two weeks was observed for polyplexes containing $34 \mathrm{wt} \%$ of PEG. At low PEG-SH/PDA ratio, the higher PDA content in SS-PAA-I7, almost twice as high as in SSPAA-IO, allows for a higher degree of PEGylation without occurrence of the side reaction with the disulfides in the polymer backbone. But also for this system, side reactions with disulfides in the polymer backbone may be the reason that the longest stability is not obtained at the highest PEG/PDA ratios. PEGylating of SS-PAA-I7 polyplexes with the longer PEG 5000 dramatically increases the stability, especially at higher PEG contents (Figure 7.2c). The presence of $29 \mathrm{wt} \%$ of PEG 5000 stabilizes the polyplexes for approximately io days and higher PEG contents increase the lifetimes even to more than one month. It is difficult to say whether the stabilization with $29 \mathrm{wt} \%$ PEG 5000 should be attributed to the PEG chain length or to the net PEG content. The absolute PEG content of polyplexes with 29 wt\% PEG 5000 lies in the same range as polyplexes with $23-34 \mathrm{wt} \%$ PEG 2000 and these polyplexes show similar lifetimes. For higher PEG contents a higher PEG/PDA ratio is required for PEG 2000 and a comparison with PEG 5000 show that side reactions, that have occurred during PEGylation, dominate here the long term stability. Apparently, side reactions are less pronounced for PEG 5000 PEGylated polyplexes, since also at maximum PEG/PDA ratios a maximum polyplex stability is observed. It may be assumed that for these polyplexes the PEG shell fully shields the core of the polyplexes from further reaction with excess of PEG-SH, avoiding destabilizing side reactions with the polymer main chain. Therefore it can be concluded that increasing the PEG chain length in these post PEGylation reactions is an efficient approach to extend the colloidal stability of the polyplexes.

\subsubsection{Polyplex stability against heparin}

PEGylation is also expected to protect polyplexes against competing interactions with other polyanions. Heparin was chosen as model polyanion and SS-PAA-Io polyplexes PEGylated with different amounts of PEG 2000 were incubated with eight different heparin concentrations. The mixtures were loaded on an ethidium bromide containing agarose gel and subsequently electrophoresed. After electrophoresis, the gels were illuminated by UV light and the presence of uncomplexed siRNA is indicated by the visualized spots of the fluorescing ethidium/siRNA complexes. In Figure 7.3 the spots on the bottom of each panel show at which heparin concentrations siRNA is released from the polyplexes. In the first picture of Figure 7.3 unPEGylated polyplexes were exposed to heparin solutions and these results served as a reference for the 
resistance of the PEGylated complexes towards heparin. The presence of $7 \mathrm{wt} \%$ PEG in polyplexes shown in the second picture did not change the stability against heparin, but most remarkably, a higher PEG content in the polyplexes has a negative effect on the resistance towards heparin. A negative contribution of increasing degrees of PEGylation was reported earlier for PEI/siRNA complexes [Io], but there a pre-PEGylation of the polymer was applied and the PEG chains may have sterically impeded the formation of stable polyplexes. The previously discussed side reactions between PEG-SH and disulfides in the polymer backbone may contribute negatively to the resistance for heparin especially at higher PEGylation degrees. In addition, in similar experiments on crosslinked particles (chapter 6) we suggested that in an exchange process the small siRNA molecules can diffuse out of the complex, when heparin diffuses

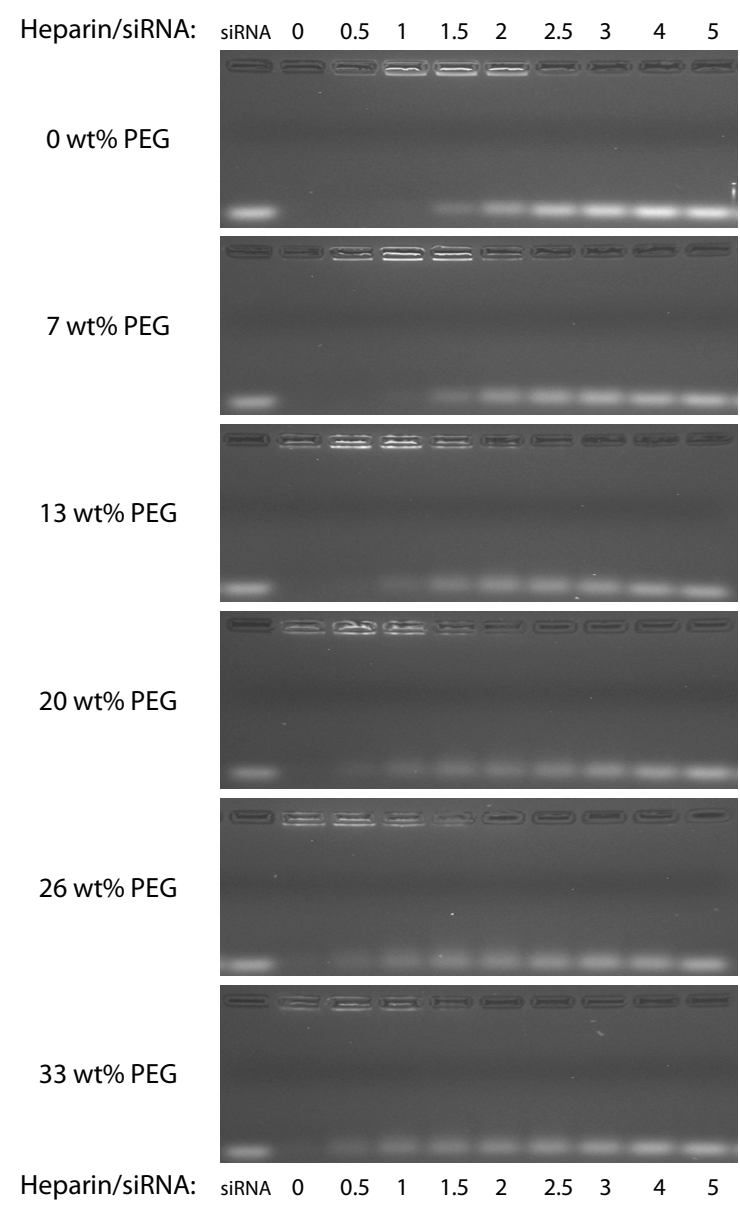

Figure 7.3: Gel electrophoresis pictures of SS-PAA-10 polyplexes at a polymer/siRNA weight ratio 24/1 in presence of increased heparin ratios. Polyplexes were post PEGylated with PEG-SH 2000.

in. Although for PEGylated particles the cationic charge is shielded to a large extent by the PEG corona and electrostatic interactions are the driving force behind this phenomenon, diffusion is not very likely to happen, but is maybe still playing a role. The use of heparin as representative polyanion in these experiments can be questioned, since it dispels siRNA already at very low concentrations. Albumin (BSA), which is present in blood at much higher concentrations, was investigated as alternative, but this compound did not dispel siRNA when it is present up to Ioo times excess (data not shown).

132 - Chapter 7 


\subsubsection{Serum nuclease protection}

A very important requirement for long-term blood circulation of siRNA polyplexes is the protection against enzymatic siRNA degradation by omnipresent nucleases. To mimick these circumstances PEGylated polyplexes of SS-PAA-I7 with PEG 2000 and free siRNA as a control were exposed to I0\% FBS and incubated at $37^{\circ} \mathrm{C}$. Aliquots were taken during a period of 24 hours and after immediate nuclease denaturation and polyplex dissociation by a mixture of $\mathrm{NaCl}$, EDTA, SDS and DTT, samples were electrophoresed on an ethidium bromide containing agarose gel. Intact siRNA was visualized by UV illumination of the fluorescing ethidium/siRNA complexes and quantified by its band intensity.

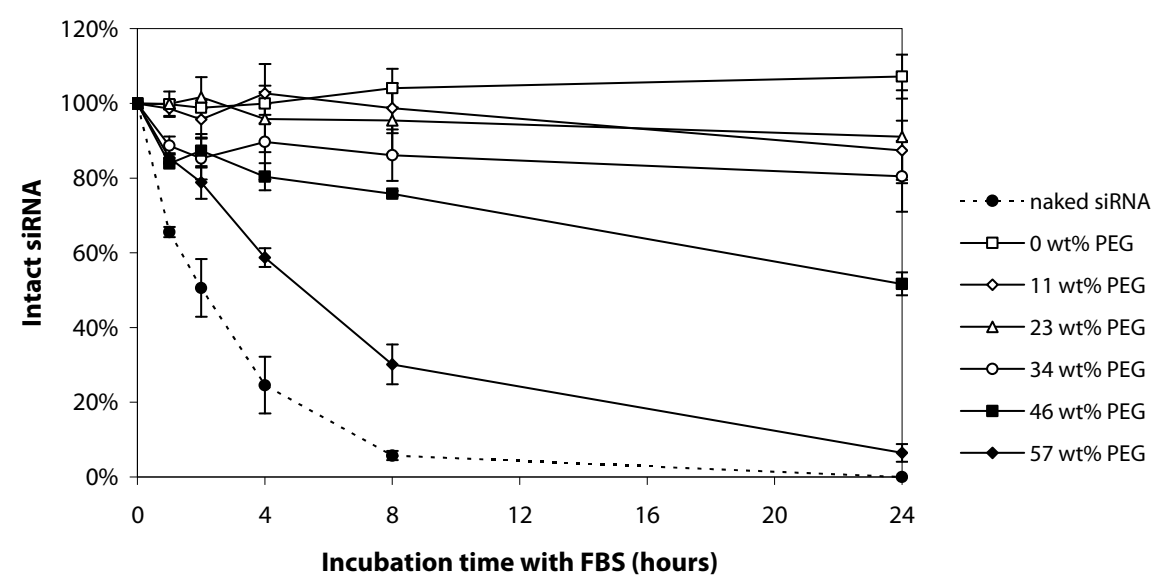

Figure 7.4: Protection of siRNA against serum nucleases by incubating SS-PAA-17 polyplexes PEGylated by PEG 2000 in $10 \% \mathrm{FBS}$ at $37^{\circ} \mathrm{C}$.

Figure 7.4 shows that naked siRNA is degrading very rapidly and has a half life time of only 2 hours under the measured conditions. siRNA in unPEGylated polyplexes does not show any degradation, but these complexes rapidly aggregate after exposure to FBS, as was concluded form the observed turbidity of the solution. With polyplexes with up to $34 \mathrm{wt} \%$ of PEG, virtually no siRNA degradation was observed. PEGylated polyplexes with increasing PEG-SH/PDA ratios decrease the protection against nucleases and at the highest PEG/PDA ratio (57 wt\%) almost all siRNA is degraded after 24 hours. A high PEG content (i.e. the use of a high PEG/PDA ratio during post-PEGylation) was unable to provide optimal protection of siRNA against a physiological salt concentrations or polyanions, by the afore-mentioned reasons. It is very likely that the increased siRNA degradation is due to a reduced protection. PEG conjugation to backbone disulfides or embedded PDA groups may have partially destabilized the polyplex and siRNA is maybe diffused out of the weakened cationic core of the polyplex. Furthermore, serum salts 
and ubiquitous anionic proteins may disassemble the polyplexes, as was observed before for PLL-PEG/siRNA complexes [40]. Optimal protection and solubility of our siRNA complexes is provided by PEG/PDA ratios of $0.4-0.6$.

\subsubsection{In vitro gene silencing}

In the next step, we evaluated the PEGylated polyplexes for their gene silencing potential by studying the knockdown efficiency of the luciferase expression in Hi299 Fluct cells, which stably express this enzyme. Although PEGylation has been shown to reduce cellular uptake and hence transfection efficiency [5, 4I], we first applied our standard transfection protocol for the PEGylated polyplexes, using an siRNA concentration of $66 \mathrm{nM}$ in absence of FBS for an incubation period of 2 hours. After a transfection time of 48 hours only very little or no silencing was obtained with PEG 2000 PEGylated SS-PAA-Io polyplexes and PEG 2000 or 5000 PEGylated SS-PAA-I7 polyplexes. Also a similar experiment in presence of I0\% FBS did not show any transfection (data not shown). Increasing the siRNA concentration and, as a consequence also the polymer concentration, increases the cytotoxicity at the used polymer/siRNA weight ratio (24/I) and is usually not a good option to improve silencing. However, cytotoxicity is frequently decreased after PEGylation [I4] and also the presence of FBS has shown to reduced cytotoxicity for poly(amido amine)s [42]. Therefore, the silencing experiment was repeated with a 4 times increased siRNA dose $(264 \mathrm{nM})$ at a constant 24/I polymer/siRNA ratio in the presence of Io\% FBS and an incubation time of 48 hours instead of 2 hours was used (Figure 7.5). No cytotoxicity was found for all the applied polyplexes, as was concluded from the 100\% luciferase expression of cells treated with non-coding siRNA only (Figure 7.5a, b and c). Even the unPEGylated polyplexes did not show any cytoxicity, despite of their cationic character and the high concentrations that were used. The observed excellent luciferase silencing of the non-PEGylated polyplexes was probably caused by precipitation and sedimentation of the polyplexes, intensifying the polyplex/cell membrane contact. This assumption is based on the turbidity of the polyplex solutions that was observed after FBS exposure in the nuclease degradation studies and also by a faint turbid layer on top of the cells after 48 hours of transfection. Appearance of turbitity was not observed with the PEGylated complexes, underlying their good solubilities necessary to make the next step towards the development of polyplexes for in vivo applications. The gene silencing efficiencies of the PEG 2000 PEGylated polyplexes (Figure 7.5a and b) with a low degree of PEGylation are comparable to Lipofectamine 2000 (Figure $7.5 \mathrm{~d}$ ), which is currently the highly effective standard in siRNA transfections. Generally, gene silencing was reduced upon increasing degree of PEGylation, but full cell viability remained for all PEGylated polyplexes.

134 - Chapter 7 

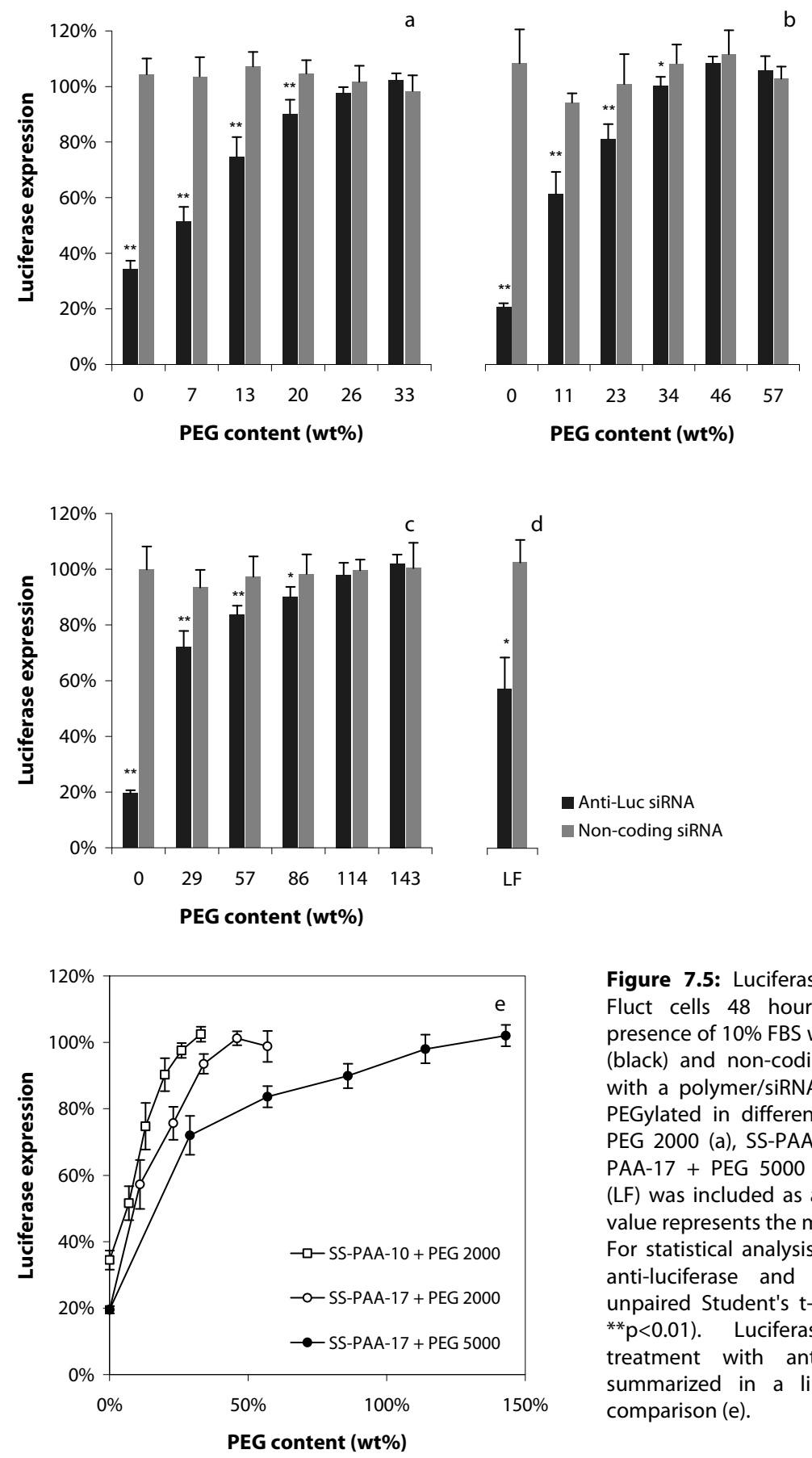

Figure 7.5: Luciferase expression of $\mathrm{H} 1299$ Fluct cells 48 hours after transfection in presence of $10 \% \mathrm{FBS}$ with anti-luciferase siRNA (black) and non-coding control siRNA (grey) with a polymer/siRNA weight ratio $24 / 1$ and PEGylated in different degrees: SS-PAA-10 + PEG 2000 (a), SS-PAA-17 + PEG 2000 (b), SSPAA-17 + PEG 5000 (c). Lipofectamine 2000 (LF) was included as a reference (d). Each bar value represents the mean $\pm S D$ of $n=3,4$ or 5 . For statistical analysis of differences between anti-luciferase and non-coding siRNA an unpaired Student's $t$-test was used $\left({ }^{*} p<0.05\right.$; $* * 0<0.01$. Luciferase expressions after treatment with anti-luciferase siRNA are summarized in a line diagram for better comparison (e). 
It is difficult to relate the degree of silencing directly to the $\zeta$-potential of the polyplexes, since the latter were determined in a different medium, but a reduced $\zeta$ potential, and as a consequence reduced cell membrane interactions, are likely the main reason for the diminished silencing. For a better visual comparison, the luciferase expressions after treatment with specific siRNA are plotted in Figure 7.5e. PEG 2000 PEGylated polyplexes of SS-PAA-I7 give slightly better silencing than their counterparts of SS-PAA-IO, which is likely originating from the intrinsically better silencing properties of the SS-PAA-I7 (without PEG), as was described in chapter 6. It is interesting that PEG 5000 PEGylated polyplexes of SS-PAA-I7 show better silencing than comparable polyplexes with PEG 2000. It has been reported that for shielding of polyplexes longer PEG chains are favored over shorter PEG chains, since longer PEG chains have higher flexibility [IO, I4], allowing for a better and tighter coverage of the polyplex surface. However, the differences in our silencing results are more likely explained by the lower stability of the PEG 2000 polyplexes due to the afore-mentioned side reactions that cleave the main chain of the SS-PAA polymers. The increased vulnerability for siRNA degradation at high PEG/PDA ratios together with a reduction of the $\zeta$-potential of the polyplexes, are believed to be the main contributors to the lower luciferase silencing. A decrease in gene silencing was not excluded on forehand for PEGylated polyplexes due to less interactions between the polyplexes and the cell membranes and a lower endosomal escape [24] and silencing values of $20-30 \%$ for polyplexes with $\zeta$-potentials as low as io $\mathrm{mV}$ are actually quite promising. As additional targeting, ligand attachment is expected to improve membrane interaction and therewith endosomal uptake, Such extension can be considered as the next step in the development of in vivo siRNA delivery systems [I8].

\subsection{Conclusions}

Reducible poly(amido amine)s containing pyridyl disulfide (PDA) moieties in the side chain were synthesized for complexation of siRNA. The self-assembled polymer/siRNA polyplex particles are very suitable for post-PEGylation by thiol functionalised PEG (PEG-SH) via a disulfide exchange reaction. It was found that the applied PEG/PDA ratio in the post-PEGylation reaction to obtain stable polyplex particles is very critical and that too high ratios resulted in side reaction of PEG-SH with disulfides in the polymer backbone, resulting in less stable particles. The optimal ratio PEG/PDA ratio was found to be in the range of $0.4-0.6$. Side reactions were avoided at this ratio and polyplex particles of $8 \mathrm{o}-\mathrm{I} 2 \mathrm{O} \mathrm{nm}$ in size and reduced surface potential increased the stability in a physiological environment and a good protection of siRNA against nucleolytic degradation was realized. These PEGylated polyplexes induced

$136 \cdot$ Chapter 7 
relatively high gene silencing in view of their reduced surface potentials. Future studies with targeting ligands on the PEG chain ends are expected to further increase the silencing potential of these systems, bringing them another step closer to therapeutic in vivo applications.

\subsection{Acknowledgement}

Thanks to Leonie Voskamp for developing PDA-containing poly(amido amine)s.

\subsection{References}

I. $\quad$ Morille, M., et al., Progress in developing cationic vectors for non-viral systemic gene therapy against cancer. Biomaterials, 2008. 29(24-25): p. 3477-3496.

2. Petersen, H., et al., Polyethylenimine-graft-poly(ethylene glycol) copolymers: Influence of copolymer block structure on DNA complexation and biological activities as gene delivery system. Bioconjugate Chemistry, 2002. 13(4): p. 845854 .

3. $\quad$ Remaut, K., et al., Nucleic acid delivery: Where material sciences and biosciences meet. Materials Science \& Engineering R-Reports, 2007. 58(3-5): p. II7I6I.

4. $\quad$ Zhong, Z.Y., et al., Low molecular weight linear polyethylenimine- $b$ poly(ethylene glycol)-b-polyethylenimine triblock copolymers: Synthesis, characterization, and in vitro gene transfer properties. Biomacromolecules, 2005. 6(6): p. 3440-3448.

5. Mishra, S., P. Webster, and M.E. Davis, PEGylation significantly affects cellular uptake and intracellular trafficking of non-viral gene delivery particles. European Journal of Cell Biology, 2004. 83(3): p. 97-III.

6. $\quad$ Kong, W.H., et al., Efficient intracellular siRNA delivery strategy through rapid and simple two steps mixing involving noncovalent post-PEGylation. Journal Of Controlled Release, 2009. I38(2): p. I4I-I47.

7. Oupicky, D., R.C. Carlisle, and L.W. Seymour, Triggered intracellular activation of disulfide crosslinked polyelectrolyte gene delivery complexes with extended systemic circulation in vivo. Gene Therapy, 200I. 8(9): p. 713-724.

8. $\quad$ Ogris, M., et al., PEGylated DNA/transferrin-PEI complexes: reduced interaction with blood components, extended circulation in blood and potential for systemic gene delivery. Gene Therapy, I999. 6(4): p. 595-605.

9. $\quad$ Petersen, H., et al., Synthesis, characterization, and biocompatibility of polyethylenimine-graft-poly(ethylene glycol) block copolymers. Macromolecules, 2002. 35(I8): p. 6867-6874.

Io. Mao, S.R., et al., Influence of polyethylene glycol chain length on the physicochemical and biological properties of poly(ethylene imine)-graft- 
poly(ethylene glycol) block copolymer/SiRNA polyplexes. Bioconjugate Chemistry, 2006. I7(5): p. I209-I2I8.

II. Glodde, M., S.R. Sirsi, and G.J. Lutz, Physiochemical properties of low and high molecular weight poly(ethylene glycol)-grafted poly(ethylene imine)

copolymers and their complexes with oligonucleotides. Biomacromolecules, 2006. 7(I): p. 347-356.

I2. Brus, C., et al., Efficiency of polyethylenimines and polyethylenimine-graftpoly (ethylene glycol) block copolymers to protect oligonucleotides against enzymatic degradation. European Journal of Pharmaceutics and Biopharmaceutics, 2004. 57(3): p. 427-430.

I3. Williams, J.H., et al., Induction of dystrophin expression by exon skipping in mdx mice following intramuscular injection of antisense oligonucleotides complexed with PEG-PEI copolymers. Molecular Therapy, 2006. I4(I): p. 88-96.

I4. Neu, M., et al., Bioreversibly crosslinked polyplexes of PEI and high molecular weight PEG show extended circulation times in vivo. Journal Of Controlled Release, 2007. I24(I-2): p. 69-80.

I5. Kim, S.H., et al., Local and systemic delivery of VEGF siRNA using polyelectrolyte complex micelles for effective treatment of cancer. Journal Of Controlled Release, 2008. I29(2): p. I07-II6.

I6. Kim, S.H., et al., PEG conjugated VEGF siRNA for anti-angiogenic gene therapy. Journal Of Controlled Release, 2006. II6(2): p. I23-I29.

I7. Brumbach, J.H., et al., Mixtures of Poly(triethylenetetramine/cystamine bisacrylamide) and Poly(triethylenetetramine/cystamine bisacrylamide)-gpoly(ethylene glycol) for Improved Gene Delivery. Bioconjugate Chemistry, 2010. 2I(Io): p. I753-I76I.

I8. Schiffelers, R.M., et al., Cancer siRNA therapy by tumor selective delivery with ligand-targeted sterically stabilized nanoparticle. Nucl. Acids Res., 2004. 32(I9): p. eI49.

I9. Ogris, M., et al., Tumor-targeted gene therapy: strategies for the preparation of ligand-polyethylene glycol-polyethylenimine/DNA complexes. Journal Of Controlled Release, 2003. 9I(I-2): p. I73-I8I.

20. Huth, S., et al., Interaction of polyamine gene vectors with RNA leads to the dissociation of plasmid DNA-carrier complexes. Journal of Gene Medicine, 2006. 8(I2): p. I4I6-I424.

2I. Okuda, T., T. Niidome, and H. Aoyagi, Cytosolic soluble proteins induce DNA release from DNA-gene carrier complexes. Journal of Controlled Release, 2004. 98(2): p. 325-332.

22. Bauhuber, S., et al., Delivery of Nucleic Acids via Disulfide-Based Carrier Systems. Advanced Materials, 2009. 2I(32-33): p. 3286-3306.

23. Lin, C. and J.F.J. Engbersen, The role of the disulfide group in disulfide-based polymeric gene carriers. Expert Opinion on Drug Delivery, 2009. 6(4): p. 42I439.

24. Fella, C., et al., Amine-reactive pyridylhydrazone-based PEG reagents for $\mathrm{pH}$ reversible PEI polyplex shielding. European Journal of Pharmaceutical Sciences, 2008. 34(4-5): p. 309-320. 
25. Xiong, M.P., et al., PH-Responsive multi-PEGylated dual cationic nanoparticles enable charge modulations for safe gene delivery. Chemmedchem, 2007. 2(9): p. I32I-I327.

26. Walker, G.F., et al., Toward synthetic viruses: Endosomal pH-triggered deshielding of targeted polyplexes greatly enhances gene transfer in vitro and in vivo. Molecular Therapy, 2005. II(3): p. 418-425.

27. Knorr, V., et al., An acetal-based PEGylation reagent for $\mathrm{pH}$-Sensitive shielding of DNA polyplexes. Bioconjugate Chemistry, 2007. I8(4): p. I2I8-I225.

28. Lin, S., et al., An Acid-Labile Block Copolymer of PDMAEMA and PEG as Potential Carrier for Intelligent Gene Delivery Systems. 2008. p. I09-II5.

29. Sun, W.C. and P.B. Davis, Reducible DNA nanoparticles enhance in vitro gene transfer via an extracellular mechanism. Journal Of Controlled Release, 2010. I46(I): p. II8-I27.

30. Feener, E.P., W.C. Shen, and H.J.P. Ryser, Cleavage of disulfide bonds in endocytosed macromolecules. A processing not associated with lysosomes or endosomes. Journal Of Biological Chemistry, I990. 265(31): p. 18780-18785.

3I. Yang, J., et al., Evaluation of disulfide reduction during receptor-mediated endocytosis by using FRET imaging. Proceedings of the National Academy of Sciences of the United States of America, 2006. 103(37): p. 13872-13877.

32. Pisoni, R.L., et al., A cysteine-specific lysosomal transport system provides a major route for the delivery of thiol to human fibroblast lysosomes: possible role in supporting lysosomal proteolysis. Journal of Cell Biology, I990. IIo(2): p. 327-335.

33. Manickam, D.S. and D. Oupicky, Polyplex gene delivery modulated by redox potential gradients. Journal Of Drug Targeting, 2006. I4(8): p. 519-526.

34. Takae, S., et al., PEG-detachable polyplex micelles based on disulfide-linked block catiomers as bioresponsive nonviral gene vectors. Journal Of The American Chemical Society, 2008. I30(18): p. 600I-6009.

35. Kwok, K.Y., et al., Formulation of highly soluble poly(ethylene glycol)-peptide DNA condensates. Journal Of Pharmaceutical Sciences, I999. 88(Io): p. 996I003.

36. Elbert, D.L. and J.A. Hubbell, Conjugate addition reactions combined with freeradical cross-linking for the design of materials for tissue engineering. Biomacromolecules, 200I. 2(2): p. 430-44I.

37. Woghiren, C., B. Sharma, and S. Stein, Protected Thiol Polyethylene-Glycol - a New Activated Polymer for Reversible Protein Modification. Bioconjugate Chemistry, I993. 4(5): p. 3I4-3I8.

38. Wallace, O.B. and D.M. Springer, Mild, selective deprotection of thioacetates using sodium thiomethoxide. Tetrahedron Letters, I998. 39(I8): p. 2693-2694.

39. Grayson, A.C.R., A.M. Doody, and D. Putnam, Biophysical and structural characterization of polyethylenimine-mediated siRNA delivery in vitro. Pharmaceutical Research, 2006. 23(8): p. 1868-1876.

40. Buyens, K., et al., Monitoring the disassembly of siRNA polyplexes in serum is crucial for predicting their biological efficacy. Journal Of Controlled Release, 20IO. I4I(I): p. 38-4I. 
4I. Burke, R.S. and S.H. Pun, Extracellular barriers to in Vivo PEI and PEGylated PEI polyplex-mediated gene delivery to the liver. Bioconjugate Chemistry, 2008. I9(3): p. 693-704.

42. $\quad$ Piest, M., et al., Novel poly(amido amine)s with bioreducible disulfide linkages in their diamino-units: Structure effects and in vitro gene transfer properties. Journal of Controlled Release, 2008. I30(I): p. 38-45.

$140 \cdot$ Chapter 7 


\title{
Chapter
}

\author{
L.J. van der $A a$ \\ P. Vader \\ R.M. Schiffelers \\ G. Storm \\ J.F.J. Engbersen
}




\begin{abstract}
In the development of potent polymeric gene carriers for siRNA delivery, a good interaction between the polymer and the nucleotide is inevitable to form small and stable polyplexes. Relatively high cationic charge densities in the polymer backbone are frequently used to provide these interactions, but are usually associated with severe cytotoxicities. As an alternative, nucleotide specific binding interaction based on intercalation was investigated to improve the polymer/siRNA complex formation. For this purpose bioreducible poly(amido amine) copolymers were synthesized with both butanolic (ABOL) and intercalating quaternary nicotinamide (Nic) side chains. The quaternary nicotinamide group was chosen as intercalating moiety because this group is a naturally occurring part of the $\mathrm{NAD}^{+}$coenzyme and is therefore expected to be nontoxic. The presence of these moieties as side chains in the poly(amido amine) copolymers proved to effectively decrease the size of the complexes and reduce the amount of polymer required for complete encapsulation of both siRNA and pDNA. Furthermore, these polymers showed to be non-hemolytic, even at the maximum degree of nicotinamide moieties in the polymer backbone. Remarkably, polyplexes with siRNA showed no appreciable gene silencing, but with pDNA excellent gene expression without any notable cytotoxicity was obtained. Tested in COS-7 cells as well as in Hi299 cells, polymers with $25 \%$ of nicotinamide in the side chains induced GFP expressions of about 4-5 times that of linear PEl. This transfection efficiency is comparable with that of $\mathrm{p}(\mathrm{CBA}-\mathrm{ABOL})$, but the two- and fourfold lower required polymer dose in COS-7 and Hi299 cells, respectively, is a major improvement.
\end{abstract}

\title{
8.1 Introduction
}

RNA interference (RNAi) is a promising strategy with the potential to cure an innumerable range of diseases. One of the major advantages over the use of DNA is that a nuclear entry is not required, since its mediator, small interfering RNA (siRNA), is active in the cytosol. The greatest challenge on the way to a clinical success is however the cellular delivery of its mediator: a double stranded 2I-27 base pair long RNA sequence. Rapid clearance, enzymatic degradation and poor cellular internalization make the administration of naked siRNA unsuitable for clinical use [I] and the success of RNAi-based therapies is dependent on a delivery system. Although virusses can be used, non-viral delivery systems are preferred, since they lack potential risks of mutagenesis and immune responses and can be produced relatively cheap in a great structural variety [2]. These systems encompass polycationic polymers and cationic lipids that spontaneously can associate with polynucleotides through electrostatic interactions to form polyplexes or lipoplexes, respectively. Recently, our group has

$142 \cdot$ Chapter 8 
developed several disulfide-containing poly(amido amine)s (SS-PAAs) that showed very promising properties as polymeric transfection reagents for pDNA [3-5]. It is however more difficult to complex siRNA, because these molecules are small, behave like rigid rods [I] and polyplex formation sometimes leads to incomplete complexation or excessive sizes and poor stability [6]. In chapter 3 we addressed this difficulty by introducing extra amines in the existing $\mathrm{p}(\mathrm{CBA}-\mathrm{ABOL})$ polymer by copolymerizing ethylene diamine ( $\mathrm{p}(\mathrm{CBA}-\mathrm{ABOL} / \mathrm{EDA})$ ), which proved to be a good strategy and contributed tremendously to the siRNA complexation and stabilization. Although these polyplexes induced good gene silencing as well, their use is limited to low concentrations, since the introduction of extra charge strongly increased the toxicity of the material. High toxicities are frequently observed for highly cationic polymers and generally considered to be a problem on the way to in vivo applications [7]. Although charge shielding can conceal this toxicity, as was demonstrated in chapter 7 , it would be more elegant to avoid the need of polymers with high charge densities at all.

Designing a successful polymeric gene carrier without cationic charge is rather illusive, since a protonable character is not only used for nucleotide complexation, but is also indispensable for efficient endosomal release [8]. However, an interesting alternative or supplementation to the use of a high cationic charge density in the

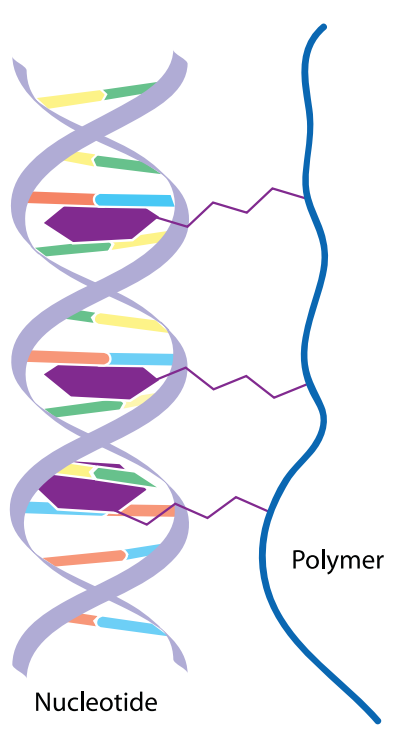

Figure 8.1: Schematic representation of the intercalation principle. The black hexagonal model intercalator is shifted in between the basepairs of the double stranded nucleotide. polymer, to obtain sufficient interaction between polymer and nucleotide, is making use of binding attractions based on intercalation. Intercalation is the insertion of planar aromatic substituents between the base pairs of double stranded nucleic acids [9] (Figure 8.I). Important driving forces for intercalation are $\pi$-stacking of the intercalating moiety with the aromatic nucleic bases, dipole-dipole interactions (especially hydrogen bonding), dispersive interactions like hydrophobic and van der Waals interactions and, if positive charge is present in the intercalator, electrostatic interactions [9-Io]. There are only a few examples known where intercalation is applied in gene delivery. The group of Rice has prepared intercalated DNA polyplexes with polyacridine compounds and showed that only complexes that have also cationic charges are taken up by the cells [II-I2]. Others have used preformed peptide-acridine conjugates to provide nuclear localization or to transfer DNA through the blood brain barrier, but also these conjugates were cocomplexated with PEI or cationic lipidic gene carriers [13-I5]. Recently, our lab reported about a novel SS-PAA having quaternized nicotinamide moieties 
in the side chain [I6]. It was found that this quaternized nicotinamide is capable to intercalate between the base pairs of DNA, since it fulfills properly the above mentioned criteria and its amide functionality is a proton donor as well as a proton acceptor in hydrogen bonding. The use of intercalating species is however not without risk. Intercalation is known to have a significant influence on the three-dimensional

polynucleotide structure. In case of intercalation with chromosomal DNA, such structural modifications may influence DNA replication and can cause base pair substitution, frameshift mutagenis or other clastogenic effects [I7]. It is therefore that intercalating compounds usually have a name as highly toxic compounds. Quaternized nicotinamide is however expected to be biocompatible, since the quaternary nicotinamide is part of the naturally occurring coenzyme $\mathrm{NAD}^{+}$and is already omnipresent in every cell. Moreover, the monocyclic aromatic nicotinamide is much smaller than well known polycyclic aromatic intercalators (e.g. acridinium compounds) and this smaller size will probably result in a more moderate insertion and interaction and less helix unwinding.

In this study it was aimed again to optimize $\mathrm{p}(\mathrm{CBA}-\mathrm{ABOL})$ for siRNA applications. In previous studies, $\mathrm{p}(\mathrm{CBA}-\mathrm{ABOL})$ has turned out to be a successful polymer for $\mathrm{pDNA}$ transfection [3]. However, it appeared that this polymer has a rather low binding affinity for siRNA due to the limited size and lower amount of negative charge of this polynucleotide. Therefore we have investigated whether the introduction of quaternary nicotinamides could improve the binding capacity of $\mathrm{p}(\mathrm{CBA}-\mathrm{ABOL})$ as an alternative for, or additional contribution to, the introduction of EDA to overcome the cytotoxicity limitations of $\mathrm{p}(\mathrm{CBA}-\mathrm{ABOL} / \mathrm{EDA})$. A small copolymer library with five different molar ratios of butanolic and quaternary nicotinamide sidegroups ( $\mathrm{p}(\mathrm{CBA}-\mathrm{ABOL} / \mathrm{Nic}))$ was synthesized and screened for optimal formation of stable and small polyplexes with good gene silencing properties. Furthermore, interactions with pDNA were also studied, since the synthesized polymers are also interesting vectors for pDNA delivery and inducing gene expression.

\subsection{Materials and methods}

\subsubsection{Materials}

All chemicals and reference materials, nicotinamide (Fluka), I-chloro-2,4dinitrobenzene (Acros), 4-amino-I-butanol (ABOL, Merck), N-Boc-I,4-diaminobutane (NHBoc, Fluka), N,N'cystaminebisacrylamide (CBA, Polysciences), n-butylamine (Aldrich), sodium 3'-[I-phenylamino-carbonyl]-3,4-tetrazolium]-bis[4-methoxy-6- 
nitro]benzenesulfonic acid hydrate (XTT, Polysciences), phenazine methosulfate (PMS, Aldrich), branched poly(ethylene imine) (25 kg/mol, Aldrich), Exgen 500 (Fermentas) and Lipofectamine 2000 (Invitrogen) were purchased in the highest purity and used without further purification. For culturing the Hi299 Fluct cells RPMI I640 medium (Lonza) completed with 2\% (v/v) PennStrepp (Lonza), I\% (v/v) glutamine (Lonza) and Io\% (v/v) fetal bovine serum (Lonza) was used. COS-7 cells were cultured in DMEM containing $4.5 \mathrm{~g} / \mathrm{l}$ of glucose (Gibco), completed with completed with $2 \%$ (v/v) PennStrepp (Lonza), $\mathrm{I} \%(\mathrm{v} / \mathrm{v})$ glutamine (Lonza) and $0 \%(\mathrm{v} / \mathrm{v})$ fetal bovine serum (Lonza). Negative control siRNA was purchased from Qiagen, fluorescein labeled siRNA (BLOCK-iT ${ }^{\mathrm{TM}}$ Fluorescent Oligo) was obtained from Invitrogen, anti-luciferase siRNA was kindly supplied by the University of Utrecht and the plasmid pCMV-GFP was purchased from Plasmid Factory (Bielefeld, Germany). Luciferase assay reagent was obtained from Promega.

\subsubsection{Synthesis of the nicotinamide Zincke salt}

A Zincke salt of nicotinamide was synthesized according to a literature procedure [I8]. $4.0 \mathrm{~g}$ (33.8 mmol, I eq) of nicotinamide was added to $19.9 \mathrm{~g}(98.3 \mathrm{mmol}, 3 \mathrm{eq})$ of molten I-chloro-2,4-dinitrobenzene and stirred at $100^{\circ} \mathrm{C}$. After I hour the flask was cooled to room temperature, the obtained yellow to brown solid was dissolved in $30 \mathrm{ml}$ of methanol, followed by precipitation in diethyl ether thrice. The precipitate was dissolved in Ioo $\mathrm{ml}$ of water and treated with activated carbon. After filtration, water was evaporated under reduced pressure and the Zincke salt was obtained as a yellow crystalline material. Yield: 5.40g (55\%). ${ }^{\mathrm{H}} \mathrm{H}$ NMR $\left(\mathrm{D}_{2} \mathrm{O}\right) \delta(\mathrm{ppm}): 8.22 \quad(\mathrm{~d}, \mathrm{IH}$, CCHCHCNO${ }_{2}$ ); 8.44 (t, IH, CHCHCCO); $8.92\left(\mathrm{~d}, \mathrm{IH}, \mathrm{CHCHCNO} \mathrm{CH}_{2}\right) ; 9.2 \mathrm{I}(\mathrm{d}, \mathrm{IH}$, $\mathrm{CHCHCCO}$ ); $9.30\left(\mathrm{~d}, \mathrm{IH}, \mathrm{CHCHN} \mathrm{N}^{+}\right.$); 9.37 (s, IH, $\mathrm{CNO}_{2} \mathrm{CHCNO}_{2}$ ), $9.63(\mathrm{~s}, \mathrm{IH}$, $\mathrm{N}^{+}$CHCCO).

\subsubsection{Synthesis p(CBA-ABOL/Nic) copolymers}

Copolymers with five different degrees of 4-amino-I-butanol (ABOL) and quaternized nicotinamide (Nic), having ABOL/Nic molar percent ratios of Ioo/o, 75/25, 50/50, 25/75 and o/100, were synthesized in a three step synthesis.

\section{p(CBA-ABOL/NHBoc)}

In the first step ABOL and $\mathrm{N}$-Boc-I,4-diaminobutane (NHBoc) were copolymerized with $N, N$-cystaminebisacrylamide (CBA) in a Michael addition polymerization. In a typical example (p(CBA-ABOL $\left.{ }_{75} / \mathrm{NHBoc}_{25}\right)$ ) $700 \mathrm{mg}$ (2.69 mmol, I eq) CBA, I8o mg (2.02 mmol 0.75 eq) $\mathrm{ABOL}$ and $\mathrm{I} 27 \mathrm{mg}(0.67 \mathrm{mmol}$, $0.25 \mathrm{eq}) \mathrm{NHBoc}$ were dissolved in 
methanol / water (4/I v/v) and were allowed to react at $45^{\circ} \mathrm{C}$ in the dark in a nitrogen atmosphere. The reaction mixture became homogeneous within one hour. After Io days the polymerization was terminated by addition of $18 \mathrm{mg} \mathrm{ABOL}$ and $\mathrm{I} 3 \mathrm{mg}$ NHBoc to consume remaining toxic acrylamide endgroups. After 2 days termination, the crude polymer was obtained by evaporation of all the solvents under reduced pressure. Yield: I00\%. ' ${ }^{\mathrm{H}} \mathrm{NMR}\left(\mathrm{D}_{2} \mathrm{O}\right) \delta(\mathrm{ppm})$ : I.39 (s, 9H, C $\left.\left(\mathrm{CH}_{3}\right)_{3}\right) ;$ I.58 (m, $\left.2 \mathrm{H}, \mathrm{CH}_{2} \mathrm{CH}_{2} \mathrm{CH}_{2} \mathrm{NR}_{2}\right) ;$ i.77 $\left(\mathrm{m}, 2 \mathrm{H}, \mathrm{CH}_{2} \mathrm{CH}_{2} \mathrm{OH}\right.$ and $\left.\mathrm{CH}_{2} \mathrm{CH}_{2} \mathrm{NHCOO}\right) ; 2.77\left(\mathrm{t}, 2 \mathrm{H}, \mathrm{NHCOCH}_{2}\right) ; 2.83(\mathrm{t}, 4 \mathrm{H}$, $\left.\mathrm{CH}_{2} \mathrm{SSCH}_{2}\right) ; 3.22\left(\mathrm{t}, 2 \mathrm{H}, \mathrm{CH}_{2} \mathrm{CH}_{2} \mathrm{CH}_{2} \mathrm{NR}_{2}\right) ; 3.44\left(\mathrm{t}, 4 \mathrm{H}, \mathrm{CH}_{2} \mathrm{NRCH}\right.$ ); $3.5 \mathrm{I}(\mathrm{t}, 4 \mathrm{H}$, $\left.\mathrm{NH} \mathrm{CH}_{2} \mathrm{CH}_{2} \mathrm{SSCH}_{2} \mathrm{CH}_{2} \mathrm{NH}\right) ; 3,60\left(\mathrm{t}, 2 \mathrm{H}, \mathrm{CH}_{2} \mathrm{OH}\right)$

\section{p(CBA-ABOL/NH $\left.{ }_{2}\right)$}

In the next step, the Boc-protecting group was removed from the $\mathrm{p}(\mathrm{CBA}$ ABOL/NHBoc) copolymers. In a typical example $\left(\mathrm{p}\left(\mathrm{CBA}-\mathrm{ABOL}_{75} /\left(\mathrm{NH}_{2}\right)_{25}\right)\right) 400 \mathrm{mg}$ of the Boc-protected polymer was dissolved in $5 \mathrm{ml}$ of a trifluoroacetic acid / dichloromethane $3 / \mathrm{I}(\mathrm{v} / \mathrm{v})$ mixture. After 5 min stirring at room temperature, the solvent was evaporated under reduced pressure. $5 \mathrm{ml}$ of dichloromethane were added twice to evaporate the last traces of trifluoroacetic acid. The deprotected polymer was subsequently dissolved in water and the $\mathrm{pH}$ was adjusted to 5 . The polymer was further purified by ultrafiltration ( $\mathrm{MWCO}$ гоoо, $\mathrm{pH}$ ) and recovered as its $\mathrm{HCl}$ salt by lyophilization. Yield: 33\%. ' $\mathrm{H}$ NMR $\left(\mathrm{D}_{2} \mathrm{O}\right) \delta$ (ppm): I. 57 (m, $\left.2 \mathrm{H}, \mathrm{CH}_{2} \mathrm{CH}_{2} \mathrm{CH}_{2} \mathrm{NR}_{2}\right) ; \mathrm{I} .73(\mathrm{~m}$, $\left.2 \mathrm{H}, \mathrm{CH}_{2} \mathrm{CH}_{2} \mathrm{OH}\right) ; \mathrm{I} .8 \mathrm{I}\left(\mathrm{m}, 2 \mathrm{H}, \mathrm{CH}_{2} \mathrm{CH}_{2} \mathrm{NH}_{2}\right) ; 2.75(\mathrm{t}, 2 \mathrm{H}, \mathrm{NHCOCH}) ; 2.8 \mathrm{I}(\mathrm{t}, 4 \mathrm{H}$, $\left.\mathrm{CH}_{2} \mathrm{SSCH}_{2}\right) ; 3.0 \mathrm{I}$ (t, $\left.2 \mathrm{H}, \mathrm{CH}_{2} \mathrm{NH}_{2}\right) ; 3.2 \mathrm{I}$ (t, $\left.2 \mathrm{H}, \mathrm{CH}_{2} \mathrm{CH}_{2} \mathrm{CH}_{2} \mathrm{NR}_{2}\right) ; 3.43$ (t, $4 \mathrm{H}$, $\mathrm{CH}_{2} \mathrm{NRCH}$ ); $3.50\left(\mathrm{t}, 4 \mathrm{H}, \mathrm{NHCH} \mathrm{CH}_{2} \mathrm{SSCH}_{2} \mathrm{CH}_{2} \mathrm{NH}\right) ; 3,59\left(\mathrm{t}, 2 \mathrm{H}, \mathrm{CH}_{2} \mathrm{OH}\right)$

\section{p(CBA-ABOL/Nic)}

In the final step, quaternized nicotinamide functionalities were introduced on the primary amines of the polymer via a Zincke reaction. Typically, $300 \mathrm{mg}$ of $\mathrm{p}$ (CBA$\left.\mathrm{ABOL}_{75} /\left(\mathrm{NH}_{2}\right)_{25}\right)$ (0.2I mmol, I eq of primary amines) and $84 \mathrm{mg}$ (0.3I mmol, I.2 eq) of nicotinamide Zincke salt were dissolved in $3 \mathrm{ml}$ of methanol and stirred at room temperature. Drops of a methanolic sodium hydroxide solution were added until the color of the solution changed from yellow to deep red indicating that the Zincke reaction proceeded due to the deprotonation of the primary amines. After 2 hours of stirring, $42 \mu \mathrm{l}$ ( $0.42 \mathrm{mmol}, 2 \mathrm{eq})$ of $\mathrm{n}$-butylamine was added to finalize the reaction, yielding a yellow solution indicating that all the Zincke salt was converted. The 2,4dinitroaniline byproduct was precipitated with Io $\mathrm{ml}$ of water and removed by centrifugation and filtration through a $0.45 \mu \mathrm{m}$ syringe filter. The remaining polymer solution was finally purified by ultrafiltration (MWCO ıоoо, $\mathrm{pH} 5)$ and recovered as its

$146 \cdot$ Chapter 8 
$\mathrm{HCl}$ salt by lyophilization. Yield: $55 \%{ }^{\mathrm{I}} \mathrm{H}$ NMR $\left(\mathrm{D}_{2} \mathrm{O}\right) \delta(\mathrm{ppm}):$ I. $58(\mathrm{~m}, 2 \mathrm{H}$, $\left.\mathrm{CH}_{2} \mathrm{CH}_{2} \mathrm{CH}_{2} \mathrm{OH}\right) ; \mathrm{I} .73\left(\mathrm{~m}, 2 \mathrm{H}, \mathrm{CH}_{2} \mathrm{CH}_{2} \mathrm{OH}\right) ; \mathrm{I} .87\left(\mathrm{~m}, 2 \mathrm{H}, \mathrm{CH}_{2} \mathrm{CH}_{2} \mathrm{CH}_{2} \mathrm{~N}^{+}\right) ; 2 . \mathrm{I2}(\mathrm{m}, 2 \mathrm{H}$, $\left.\mathrm{CH}_{2} \mathrm{CH}_{2} \mathrm{~N}^{+}\right) ; 2.76\left(\mathrm{t}, \quad 2 \mathrm{H}, \quad \mathrm{NHCOCH}_{2}\right) ; 2.8 \mathrm{I}\left(\mathrm{t}, \quad 4 \mathrm{H}, \mathrm{CH}_{2} \mathrm{SSCH}_{2}\right) ; 3.23(\mathrm{t}, \quad 2 \mathrm{H}$, $\mathrm{CH}_{2} \mathrm{CH}_{2} \mathrm{CH}_{2} \mathrm{NR}_{2}$ ); 3.44 (t, ${ }_{4} \mathrm{H}, \mathrm{CH}_{2} \mathrm{NRCH}$ ); 3.50 (t, $4 \mathrm{H}, \mathrm{NH} \mathrm{CH}_{2} \mathrm{CH}_{2} \mathrm{SSCH}_{2} \mathrm{CH}_{2} \mathrm{NH}$ ); 3.59 (t, $\left.2 \mathrm{H}, \mathrm{CH}_{2} \mathrm{OH}\right) ; 4.74\left(\mathrm{t}, 2 \mathrm{H}, \mathrm{CH}_{2} \mathrm{~N}^{+}\right) ; 8 . \mathrm{I} 8$ (t, $\left.\mathrm{IH}, \mathrm{CHCHCCO}\right) ; 8.88$ (d, $\left.\mathrm{IH}, \mathrm{CH} C H C \mathrm{CO}\right) ;$ $9.05\left(\mathrm{~d}, \mathrm{IH}, \mathrm{CH} C H \mathrm{~N}^{+}\right) ; 9.33\left(\mathrm{~s}, \mathrm{IH}, \mathrm{N}^{+} \mathrm{CHCCO}\right)$

\subsubsection{Viscosimetry measurements}

Viscosity measurements were performed in an Ubbelohde micro viscosimeter in a thermostated bath at $25^{\circ} \mathrm{C}$. The polymers were lyophilized once again before preparing the polymer solutions, to guarantee that hygroscopic moisture attraction did not influence the concentration. Polymers were dissolved in a sodium acetate buffer (Ioo $\mathrm{mM}, \mathrm{pH}$ 4.5) at a concentration of $5 \mathrm{mg} / \mathrm{ml}$ at least 4 hours before viscosity measurements.

\subsubsection{Buffer capacity}

The buffer capacity was determined by an acid-base titration. All polymers were dissolved with a concentration of $1.5 \mathrm{mM}$ of protonable nitrogens in $150 \mathrm{mM} \mathrm{NaCl}$. Io $\mathrm{ml}$ of these solutions were taken out and the $\mathrm{pH}$ was adjusted to 3.0 using $0.5 \mathrm{M} \mathrm{HCl}$. Subsequently, this solution was titrated with o.or $\mathrm{M} \mathrm{NaOH}$ to $\mathrm{pH}$ io using an automated titrator (Metrohm 702 SM Titrino). As a reference, the same procedure was applied to branched PEI ( $25 \mathrm{~kg} / \mathrm{mol})$ and $150 \mathrm{mM} \mathrm{NaCl}$ solutions. The buffer capacity is defined as the percentage of nitrogen becoming deprotonated from $\mathrm{pH}$ 5.I to $\mathrm{pH} 7.4$ and can be calculated from (I):

$$
\text { Buffer capacity }=\frac{C_{\mathrm{NaOH}}\left(\Delta V_{\mathrm{p}}-\Delta V_{\mathrm{NaCl}}\right)}{n} \times 100 \%
$$

Where $\Delta V_{p}$ and $\Delta V_{N a C l}$ are the volumes of $\mathrm{NaOH}$ solution added between $\mathrm{pH}$ 5.I and 7.4 to the polymer solution and a blank $\mathrm{NaCl}$ solution, respectively, and $n$ is total amount of protonable nitrogens present in the polymer solution.

\subsubsection{Polyplex preparation}

Polyplexes at different polymer/nucleotide mass ratios were prepared in HEPES buffered glucose (HBG: $20 \mathrm{mM}$ HEPES, $\mathrm{pH}$ 7.4, $5 \mathrm{wt} \%$ glucose). The polymer solution 
was added to the nucleotide solution in a volume ratio of $4 / \mathrm{I}$, followed by $5 \mathrm{~s}$ vortexing and $30 \mathrm{~min}$ incubation at room temperature.

\subsubsection{Polyplex properties}

Polyplexes containing $6.25 \mu \mathrm{g} / \mathrm{ml}$ siRNA or $10 \mu \mathrm{g} / \mathrm{ml} \mathrm{pDNA}$ were prepared at five different polymer/nucleotide mass ratios (3/I, 6/I, I2/I, 24/I and 48/I) as described above. The hydrodynamic diameter and the $\zeta$-potential were measured by dynamic light scattering on a Zetasizer Nano ZS (Malvern Instruments) at $25^{\circ} \mathrm{C}$.

\subsubsection{Gel retardation and polyplex degradation}

Polyplexes containing $40 \mu \mathrm{g} / \mathrm{ml}$ siRNA or $20 \mu \mathrm{g} / \mathrm{ml}$ pDNA were prepared as described above at seven different polymer/siRNA mass ratios (0.75/I, I.5/I, 3/I, 6/I, I2/I, $24 / \mathrm{I}, 48 / \mathrm{I})$. To test polymer degradation by disulfide reduction, glutathione (GSH) or DTT were added 30 min after polyplex formation to obtain a final concentration of 15 mM GSH or 7.5 mM DTT, corresponding with a three times excess of thiols over the disulfides in the polymer backbone in the highest polymer/siRNA ratio. After another 30 minutes (with or without GSH or DTT incubation), $15 \mu$ of polyplex solution was mixed with $3 \mu$ of loading buffer and transferred to an agarose gel (4.o wt\% for siRNA and $0.8 \mathrm{wt} \%$ for pDNA) containing I.25 $\mu \mathrm{M}$ ethidium bromide. Electrophoresis was performed for $60 \mathrm{~min}$ at $90 \mathrm{~V}$ in a TAE running buffer $(40 \mathrm{mM}$ tris(hydroxymethyl)aminomethane, $20 \mathrm{mM}$ acetic acid, Io $\mathrm{mM}$ EDTA, $\mathrm{pH} 8,0$ ) supplemented with I.25 $\mu \mathrm{M}$ ethidium bromide. After electrophoresis, pictures were taken on a Biorad Gel Doc 2000 under UV illumination and analyzed using Biorad Multi Analyst software version I.I.

\subsubsection{Hemolysis}

Hemolytic activity of the polymers was tested as described by Meyer [I9] with a few modifications. Human erythrocytes were isolated from freshly obtained citrate treated blood by washing and centrifugation in PBS four times ( $800 \mathrm{~g}$, Io min, $4^{\circ} \mathrm{C}$ ). After the final washing step, the erythrocyte pellet was diluted to times in $150 \mathrm{mM} \mathrm{NaCl}$. Polymer solutions were prepared in HBS (HEPES buffered saline, $20 \mathrm{mM}$ HEPES, pH $7.4,130 \mathrm{mM} \mathrm{NaCl})$ at $\mathrm{I} .25 \mathrm{mg} / \mathrm{ml}$ and were diluted 8 times. Triton X-1oo I\% (v/v) in HBS was used as a positive control; plain HBS served as negative control. All solutions were filled out in triplicate in $\mathrm{I} 20 \mu \mathrm{l}$ portions in a V-bottom 96 well plate and the plates were preincubated at $37^{\circ} \mathrm{C}$ for $20 \mathrm{~min}$. Then $30 \mu \mathrm{l}$ of erythrocyte suspension was added and the plates were incubated at $37^{\circ} \mathrm{C}$ under constant shaking. After $30 \mathrm{~min}$, the plates were

$148 \cdot$ Chapter 8 
centrifuged ( $300 \mathrm{~g}$, Io $\mathrm{min}, 20^{\circ} \mathrm{C}$ ), $60 \mu \mathrm{l}$ of supernatant was transferred to a flat bottom 96 well plate and were analyzed for hemoglobin absorption at $405 \mathrm{~nm}$ using a plate reader (Magellan Tecan Safire II).

\subsubsection{In vitro gene silencing}

Knockdown efficiency was determined by silencing luciferase expression in $\mathrm{NCl}-$ Hı299 cells, stably expressing firefly luciferase. Knockdown and cell viability were evaluated in two parallel sessions, using anti-luciferase and non-coding siRNA, respectively. Cells were seeded in 96 well plates with a density of 8000 cells per well. After $24 \mathrm{~h}$ incubation at $37^{\circ} \mathrm{C}$ in a humidified atmosphere containing $5 \% \mathrm{CO}_{2}$, medium was replaced with Ioo $\mu$ fresh medium without FBS. Polyplexes containing $6.25 \mu \mathrm{g} / \mathrm{ml}$ siRNA were prepared at five different polymer/siRNA mass ratios (3/I, 6/I, I2/I, 24/I and $48 / \mathrm{I})$ as described above. Lipofectamine 2000 was used as a reference and complexes were prepared according to the manufacturer's protocol. Polyplexes ( $20 \mu \mathrm{l}$ per well) were added to the cells in quatro after I hour incubation with fresh medium, resulting in a final siRNA concentration of $66 \mathrm{nM}$. After 2 hours of transfection, polyplex medium was replaced by complete culture medium and the cells were incubated for another 48 hours. Cells were lysed in a freeze/thaw cycle and $50 \mu \mathrm{l}$ of the cell lysate was mixed with $50 \mu l$ luciferase assay reagent containing the substrate luciferin. After too - 220 seconds (in this timeframe the emitted light is constant - data not shown) the luciferase activity was determined by measuring the luminescence at $25^{\circ} \mathrm{C}$ for 4 seconds on a PerkinElmer I420 Victor ${ }^{3}$ plate reader. Luciferase activity of untreated cells was defined as $100 \%$ expression.

\subsubsection{Uptake of siRNA complexes}

The uptake of siRNA complexes was studied by flow cytometry using NCl-Hi299 cells. Cells were seeded in 24 well plates with a density of 48000 cells per well. After $24 \mathrm{~h}$ incubation at $37^{\circ} \mathrm{C}$ in a humidified atmosphere containing $5 \% \mathrm{CO}_{2}$, medium was replaced with $600 \mu$ f fresh medium without FBS. Polyplexes containing $6.25 \mu \mathrm{g} / \mathrm{ml}$ siRNA were prepared at polymer/siRNA mass ratio 24/I as described above using FITC labeled siRNA. Lipofectamine 2000 was used as a reference and complexes were prepared according to the manufacturer's protocol. Polyplexes (I20 $\mu \mathrm{l}$ per well) were added to the cells in duplo after I hour incubation with fresh medium, resulting in a final siRNA concentration of $66 \mathrm{nM}$. After 2 hours of transfection, the cells were washed with PBS, trypsinized and suspended in PBS containing Io \% (v/v) FBS. The mean fluorescence intensity per cell was determined on a Becton Dickenson FACSCalibur flow cytometer. 


\subsubsection{Fluorescein labeled siRNA fluorescence}

Polyplexes containing fluorescein labeled siRNA were prepared in 24/I polymer/siRNA weight ratio as described above. After 30 minutes incubation, the fluorescence of the solution was measured on a Varian Cary Eclipse fluorescence spectrophotometer $\left(\lambda_{\mathrm{exc}}=494 \mathrm{~nm} ; \lambda_{\mathrm{em}}=52 \mathrm{Inm}\right)$.

\subsubsection{In vitro gene expression}

Transfection and cell viability experiments were performed with COS-7 cells or $\mathrm{NCl}-\mathrm{H} 299$ cells using pCMV-GFP DNA as a reporter gene. Gene expression (green fluorescent protein) and cell viability (XTT) were evaluated in two separate parallel sessions. Cells were seeded in 96 well plates with a density of Ioooo (COS-7) or 8000 (Hi299) cells per well. After $24 \mathrm{~h}$ incubation at $37^{\circ} \mathrm{C}$ in a humidified atmosphere containing $5 \% \mathrm{CO}_{2}$, medium was replaced with Ioo $\mu$ l fresh medium without $\mathrm{FBS}$. Polyplexes containing Io $\mu \mathrm{g} / \mathrm{ml}$ pDNA were prepared at five different polymer/siRNA mass ratios (3/I, 6/I, I2/I, 24/I and 48/I) as described above. Linear PEI (Exgen 500, N/P = $5 / \mathrm{I}$ ) was used as a reference. Optimized transfection conditions were used for both cell lines and polyplexes (Ioo $\mu \mathrm{l}$ (COS-7) or $50 \mu \mathrm{l}$ (Hi299) per well) were added to the cells in quatro after I hour incubation with fresh medium. After I hour (COS-7) or 2 hours (HI299) of transfection, polyplex medium was replaced by complete culture medium and the cells were incubated for another 48 hours. Transfection efficiency was determined by measuring the GFP expression on a Magellan Tecan Safire Il 96 wells plate reader. Excitation was at $480 \mathrm{~nm}$ and optimal emission was determined at $503 \mathrm{~nm}$. Cell viability was assessed by an XTT proliferation assay in which untreated cells were defined as I00\% viable. $48 \mathrm{~h}$ after transfection the cells were washed and incubated for I hour in colorless culture medium supplemented with $0.5 \mathrm{mM}$ XTT and $25 \mu \mathrm{M}$ PMS. Absorption of the orange colored formazan salt, formed by metabolic active cells, was determined on a Magellan Tecan Safire Il 96 wells plate reader at $450 \mathrm{~nm}$ in colorless culture medium.

\subsection{Results and discussion}

\subsubsection{Synthesis and characterization of the copolymers}

Five bioreducible poly(amido amine) copolymers (SS-PAA) with different degrees of quaternized nicotinamide sidegroups were synthesized as is displayed in Scheme 8.I.

$150 \cdot$ Chapter 8 

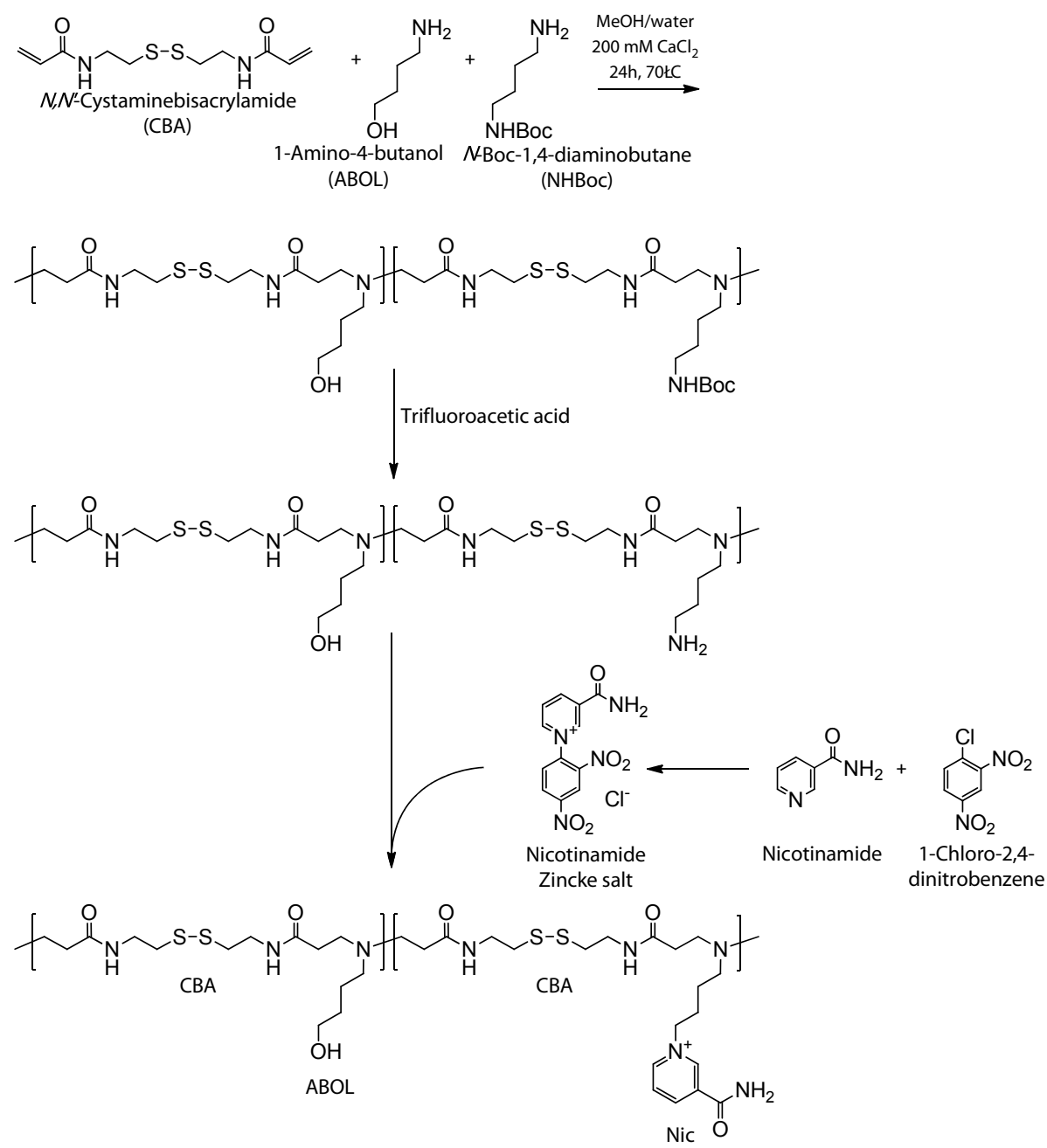

Scheme 8.1: Synthesis of the $p(C B A-A B O L / N i c)$ copolymers and the required nicotinamide Zincke salt.

First $N, N$ '-cystaminebisacrylamide (CBA), I-amino-4-butanol (ABOL) and $N$-BocI,4-diaminobutane (NHBoc) were polymerized in a Michael addition polymerization yielding polymers with butyl sidegroups having either a hydroxyl (ABOL) or Bocprotected amine (NHBoc) functionality in five different molar percent ratios. In the second step the Boc-protecting group was removed with trifluoroacetic acid, to obtain pending primary amine side groups. These primary amines were converted into quaternized nicotinamides (Nic) by a Zincke reaction, which is a versatile reaction to obtain quaternized pyridinium compounds without the use of halide compounds [I8, 2o]. For this Zincke modification, nicotinamide was activated with I-chloro-2,4dinitrobenzene to form the so-called Zincke salt of nicotinamide, which was used in the 
final step to introduce the quaternized nicotinamide moieties to the polymer. An excess of primary amines is necessary to finalize the Zincke reaction [20], therefore $n$ butylamine was added and the resulting n-butyl nicotinamide byproduct was removed by exhaustive ultrafiltration. All nicotinamide-containing polymers were obtained as a yellow brittle material and the obtained $\mathrm{ABOL} / \mathrm{Nic}$ molar percent ratios were in accordance with the $\mathrm{ABOL} / \mathrm{NHBoc}$ feed ratios in the polymerization reaction within a deviation of maximally $8 \%$ (Table 8.I).

Table 8.1: Polymer characteristics.

\begin{tabular}{lllll}
\hline & $\begin{array}{l}\text { Feed } \\
\text { composition }^{\mathbf{a}}\end{array}$ & $\begin{array}{l}\text { Obtained } \\
\text { composition }^{\mathbf{b}}\end{array}$ & $\begin{array}{l}\text { Intrinsic viscosity } \\
[\mathbf{n}] \mathbf{( d l / g})^{\mathbf{c}}\end{array}$ & $\begin{array}{l}\text { Buffer } \\
\text { capacity }^{\mathbf{d}}\end{array}$ \\
\hline \multirow{2}{*}{$\mathrm{ABOL}$} & $100 / 0$ & & 0.28 & $73 \%$ \\
$/$ & $75 / 25$ & $75 / 25$ & 0.21 & $54 \%$ \\
$\mathrm{Nic}$ & $50 / 50$ & $42 / 58$ & 0.19 & $56 \%$ \\
& $25 / 75$ & $33 / 67$ & 0.20 & $59 \%$ \\
& $0 / 100$ & & 0.19 & $62 \%$ \\
\hline
\end{tabular}

(a) Stoichiometrical feed ratio of monomers; (b) Determined by ${ }^{1} \mathrm{H} N \mathrm{NR}$; (c) Determined in an Ubbelohde micro viscosimeter in $100 \mathrm{mM}$ acetate buffer with $\mathrm{pH} 4.5$; (d) Determined by acid/base titration; Buffer capacity of b-PEI (25 $\mathrm{kg} / \mathrm{mol}$ ) is $15 \%$ (measured under the same conditions).

The obtained compositions of the complete polymer series were considered suitable for the evaluation of effects of the quaternary nicotinamide group on gene delivery properties. The molecular weights of all the polymers were estimated by intrinsic viscosimetry measurements and expected to be in the same range, since all the viscosities are rather similar

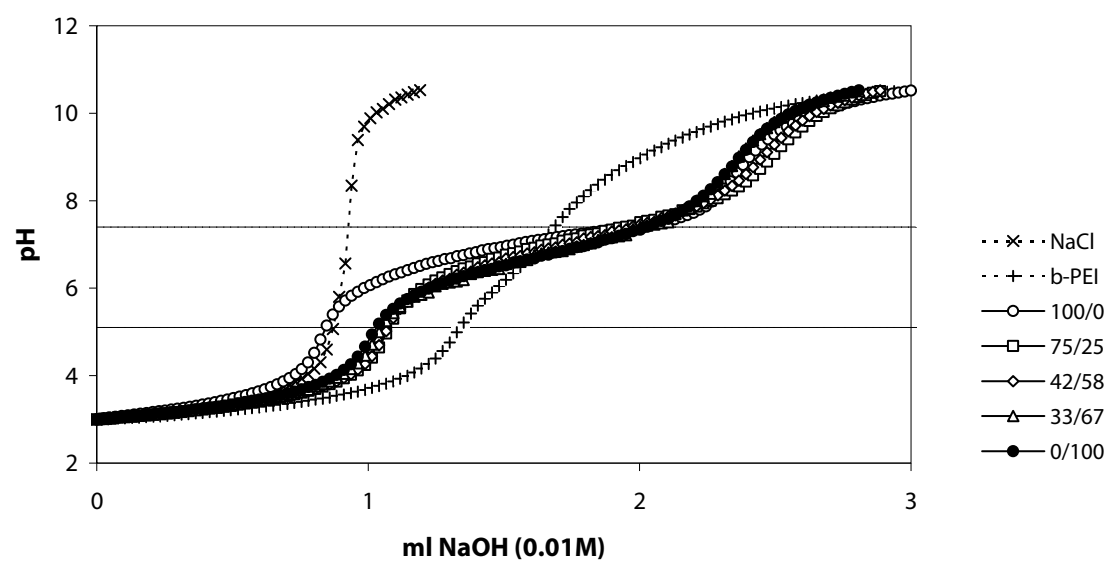

Figure 8.2: Titration curves of $\mathrm{p}(\mathrm{CBA}-\mathrm{ABOL} / \mathrm{Nic})$ obtained by titration of $0.015 \mathrm{mmol}$ protonable nitrogens (polymer) with $0.01 \mathrm{M}$ sodium hydroxide solution. b-PEI $(25 \mathrm{~kg} / \mathrm{mol})$ was included as a reference.

152 . Chapter 8 
The buffering behavior of the polymers was studied by titration between $\mathrm{pH}$ 5.I and 7.4, the endosomal buffer range. All polymers show good buffer capacities in this zone, as is indicated by flattening of the titration curve in Figure 8.2 and the derived values in Table 8.I. Although there is some debate whether or not the so-called proton sponge effect is really responsible for endosomal escape or that increased interaction of increasingly cationically charged polymer with the endosomal membrane is the primary actor, it has been clearly shown that for these type of polymers a good buffer behavior in this zone is a prediction for good transfection properties [3, 5, I6]. It is therefore not expected that limited endosomal escape will be a dominant factor in the performance of polyplexes from these polymers.

\subsubsection{Particle properties}

The $\mathrm{p}(\mathrm{CBA}-\mathrm{ABOL} / \mathrm{Nic})$ copolymers were used to form polyplexes with both siRNA and pDNA and the hydrodynamic diameters and surface potentials were determined by dynamic light scattering (DLS). Polyplexes were prepared in non-ionic buffer solutions and although this is not matching with physiological circumstances, we have chosen these conditions to prevent possible interference with other species on the nucleotide/polymer complex formation, thus allowing determination of direct effects of polymer structure variation. From Figure $8.3 \mathrm{a}$ it is clear that $\mathrm{p}(\mathrm{CBA}-\mathrm{ABOL})$ does not form small and positive polyplexes with siRNA, similarly to observations described in chapter 3. However, the presence of a small amount of quaternary nicotinamide side groups in the polymer dramatically improves the complexation behavior. Already $25 \%$ of quaternary nicotinamide in the side groups is sufficient to form positively charged polyplexes smaller than $200 \mathrm{~nm}$ at polymer/siRNA weight ratios of 6/I and higher. Increasing the quaternary nicotinamide contents in the polymer only ameliorates this more, which is translated in small diameters $(<200 \mathrm{~nm})$ and positive $\zeta$-potentials (20 $30 \mathrm{mV}$ ) at all measured polymer siRNA/weight ratios.

The complexation characteristics of these polymers with pDNA are not very different from those of siRNA (Figure 8.3b). Incorporation of $25 \%$ quaternary nicotinamide in the polymer results in an impressively improved pDNA condensation with respect to the $\mathrm{p}(\mathrm{CBA}-\mathrm{ABOL})$ homopolymer. Furthermore, small (diameters $<200$ $\mathrm{nm}$ ) and positively charged ( $\zeta$-potentials between 20 and $30 \mathrm{mV}$ ) polyplexes are formed from a polymer to pDNA weight excess of 6 and higher for all nicotinamide-containing polyplexes. 

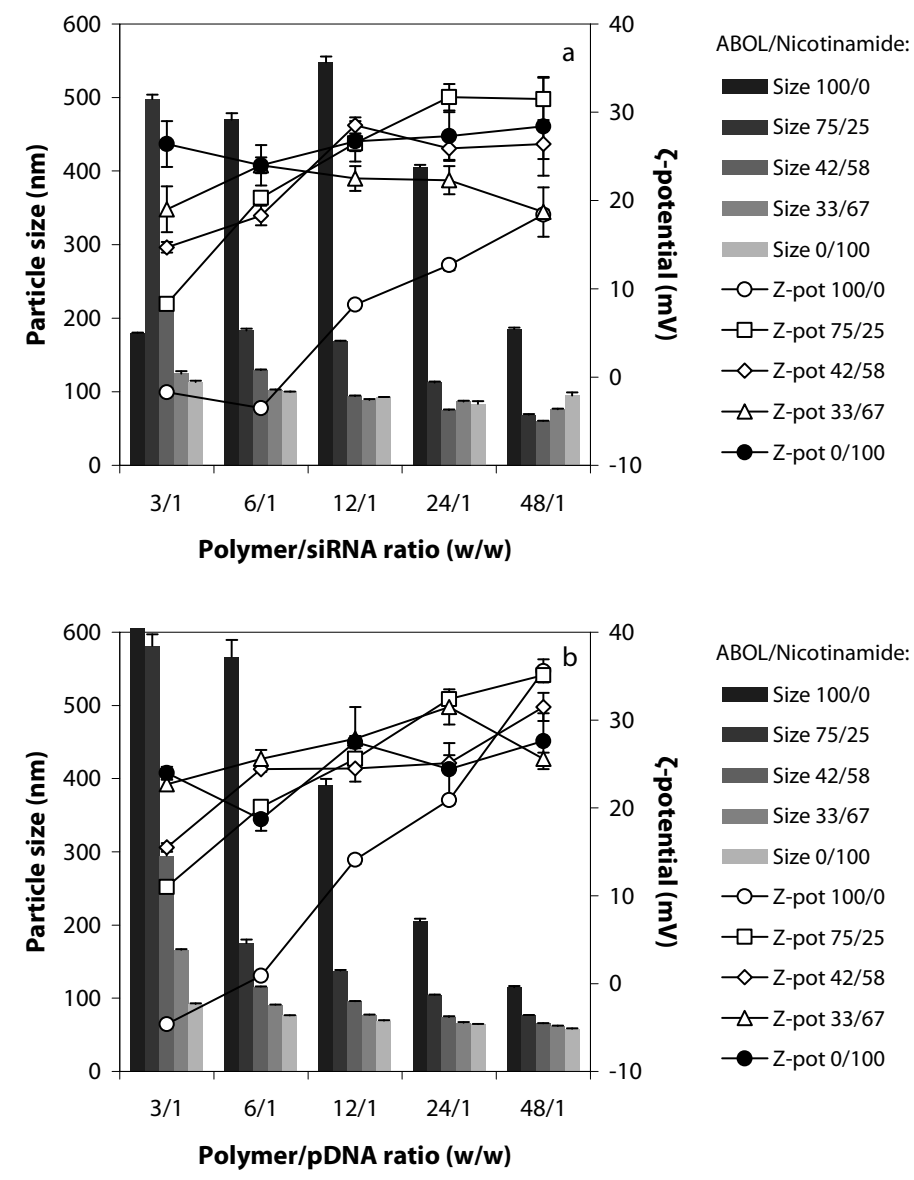

Figure 8.3: Particle size (bars) and $\zeta$-potential (lines) of polyplexes formed at several polymer/nucleotide weight ratios with siRNA (a) or pDNA (b).

DLS was not the only technique employed to study the complexation of nucleotides. Gel retardation of polyplexes followed by ethidium bromide staining of free nucleotides was also applied to evaluated the critical polymer/nucleotide ratio, needed to ensure complete encapsulation. Simultaneously, the decomplexation of the complexes upon exposing them to a reductive environment was studied, mimicking the circumstances after endosomal escape as explained extensively in chapter 2. Polyplexes were prepared in seven different polymer/nucleotide weight ratios (0.75/I, I.5/I, 3/I, 6/I, I2/I, 24/I and 48/I) and incubated in the absence as well as in the presence of glutathione or DTT as the reductive species. After loading and electrophoresis of the complexes on an agarose gel, the presence of free nucleotides was detected as fluorescing spots of intercalated ethidium/nucleotide complexes in UV light.

$154 \cdot$ Chapter 8 
In absence of glutathione

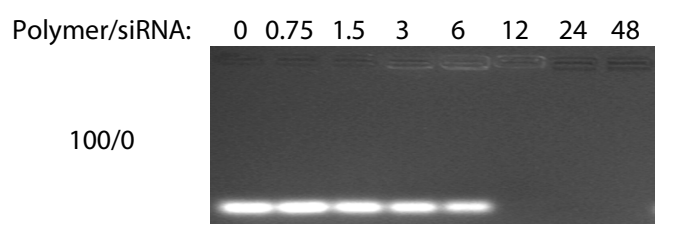

$75 / 25$

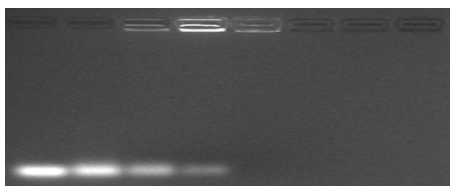

$58 / 42$
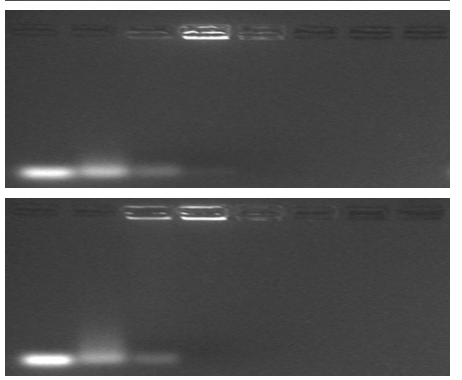

$33 / 67$

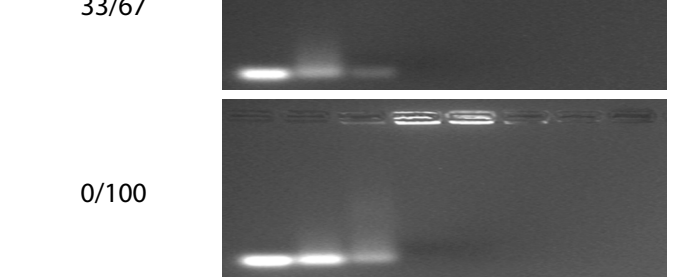

Polymer/siRNA:

$\begin{array}{llllllll}0 & 0.75 & 1.5 & 3 & 6 & 12 & 24 & 48\end{array}$
In presence of glutathione
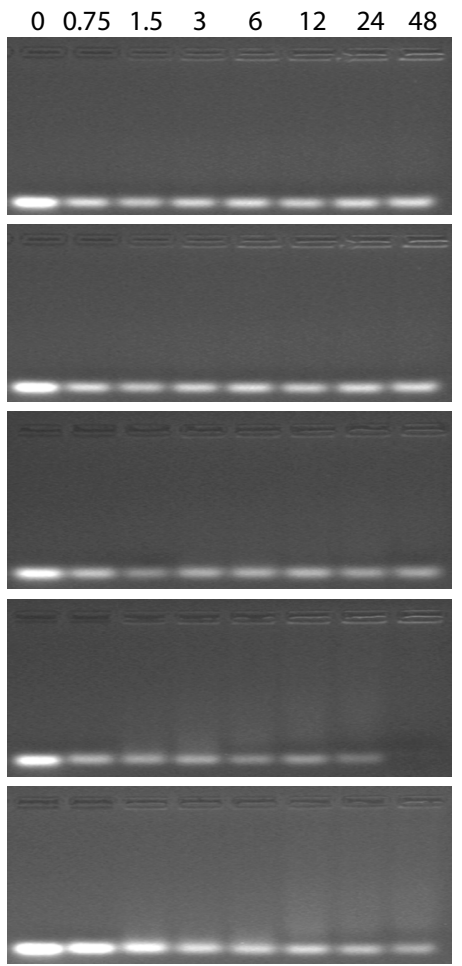

$\begin{array}{llllllll}0 & 0.75 & 1.5 & 3 & 6 & 12 & 24 & 48\end{array}$

Figure 8.4: Gel retardation profiles of polyplexes from $\mathrm{p}(\mathrm{CBA}-\mathrm{ABOL} / \mathrm{Nic}$ ) polymers at w/w ratios from 0 (siRNA only) to 48 with siRNA incubated in presence (right) or in absence (left) of $15 \mathrm{mM}$ glutathione.

The improvements on complexation of siRNA caused by the incorporation of quaternary nicotinamide groups are clearly visible on the gel retardation images as displayed in the left column of Figure 8.4. p(CBA-ABOL) is not able to retard siRNA at polymer/siRNA weight ratios of I2/I and lower. Intercalated ethidium/siRNA complex fluorescence is still visible in the starting well of the sample of the 6/I and I2/I ratio, indicating that siRNA is not completely shielded, but yet sufficiently bound to the polymer to inhibit migration through the gel. Fluorescent spots have completely disappeared from the starting wells at ratio $24 / \mathrm{I}$ and higher, illustrating complete protection of siRNA. For polymers containing quaternized nicotinamide, the critical ratios preventing siRNA migration through the gel are 6/I for polymers with $25 \%$ of quaternized nicotinamide content and 3/I for 58\% or higher. All nicotinamide polymers show complete protection of siRNA from polymer/siRNA weight ratios I2/I and higher. It is striking that the polymer containing I00\% of nicotinamide shows brighter fluorescent spots of partial complexed siRNA in the starting wells than the other 
polymers. The reason for this is unclear, but it might be suggested, that the absence of hydrophobic interactions from the butanol chains is responsible for the less tight complexation. Although the intercalative interactions are believed to be stronger, this implies that there is an optimum between hydrophobic and intercalative interactions for particle stabilization.

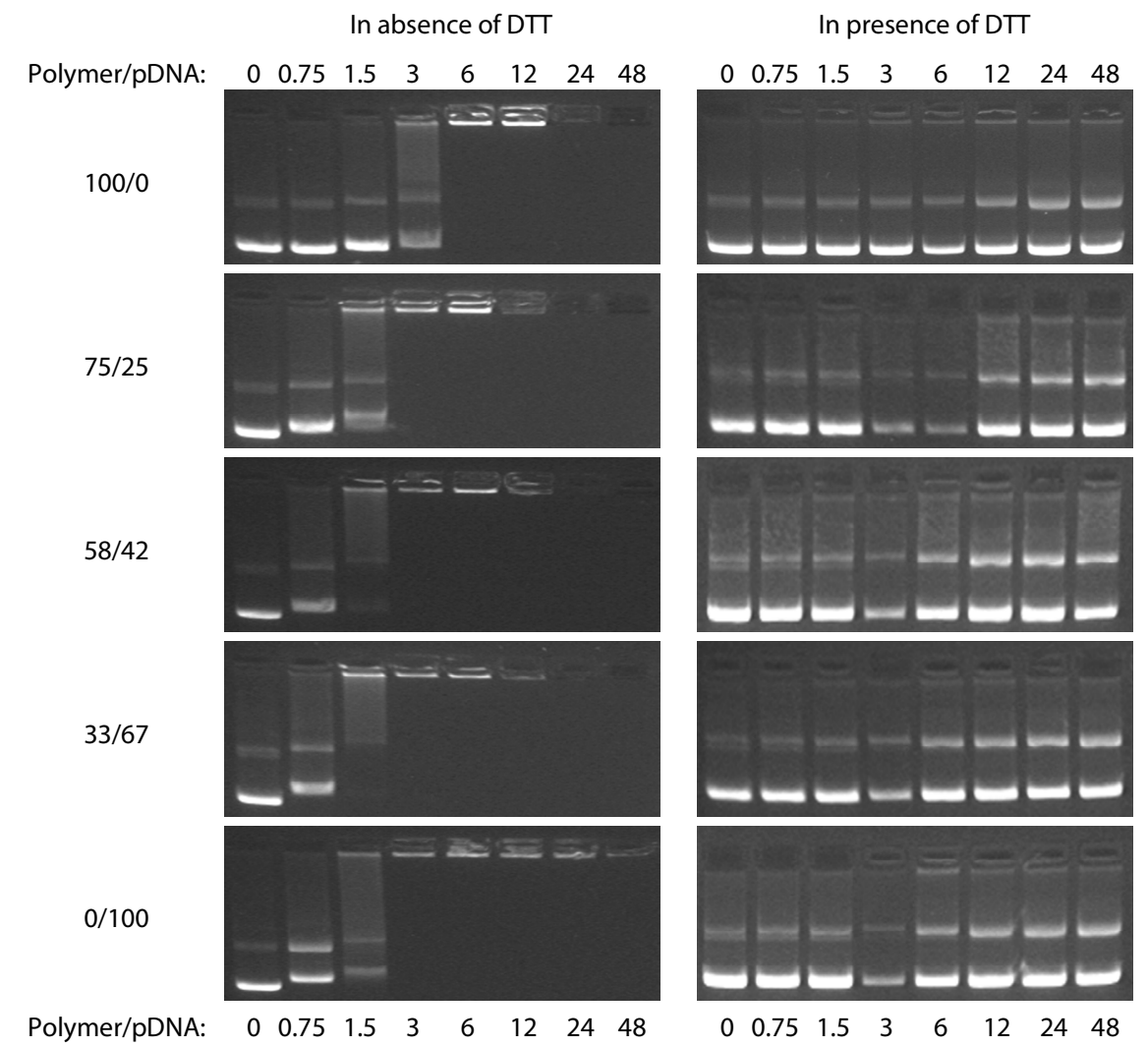

Figure 8.5: Gel retardation profiles of polyplexes from $\mathrm{p}(\mathrm{CBA}-\mathrm{ABOL} / \mathrm{Nic})$ polymers at w/w ratios from 0 ( $\mathrm{pDNA}$ only) to 48 with pDNA incubated in presence (right) or in absence (left) of $7.5 \mathrm{mM} \mathrm{DTT}$.

The right column of Figure 8.4 shows siRNA electrophoresis profiles of polyplexes incubated with glutathione. siRNA migration through the gel was observed for nearly all polyplexes, demonstrating that in spite of intercalative interactions between polymer fragments and nucleotide, siRNA was liberated successfully. The only exception is the polymer containing $67 \%$ of quaternary nicotinamide. At the highest polymer/siRNA weight ratio of 48/I siRNA was not liberated and spots at lower ratios were less faint. Maybe in this case (partially) degraded polymer fragments still have sufficient interaction with siRNA to prevent migration through the gel. Although an excess of

$156 \cdot$ Chapter 8 
glutathione was used in these experiments, complete degradation is not certain, since the reaction of glutathione with the disulfide groups in the polymer is a disulfide exchange reaction in which thiol and disulfide are in equilibrium. However, such equilibrium is not expected to thwart the final cellular application, since in cells glutathione is regenerated and this process will finally result in complete degradation of the polymer.

Similar experiments conducted on polyplexes with pDNA show the same trends as for siRNA, with the minor difference that slightly less polymer is required to prevent complete migration of pDNA through the gels and complete shielding of ethidium/DNA intercalation in the starting wells (Figure 8.5). At high polymer/pDNA weight ratios (data not shown), reductive degradation with glutathione proved to be unable to degrade the polymer sufficiently to allow pDNA migration, which may also here be attributed to the establishment of an equilibrium between glutathione and polymer fragments as mentioned above. When degradation is performed with DTT, the unreactive cyclic DTT oxidation product prevents equilibrium formation and the reduction of disulfide bonds in the polymer is forced to completion. This guarantees complete degradation of the polymer, as is clearly demonstrated in the right column of Figure 8.5 where complete release of pDNA is visible.

\subsubsection{Hemolysis}

Polycationic species are known to interact with negatively charged lipid membranes. Although membrane interactions are desired for proper gene delivery

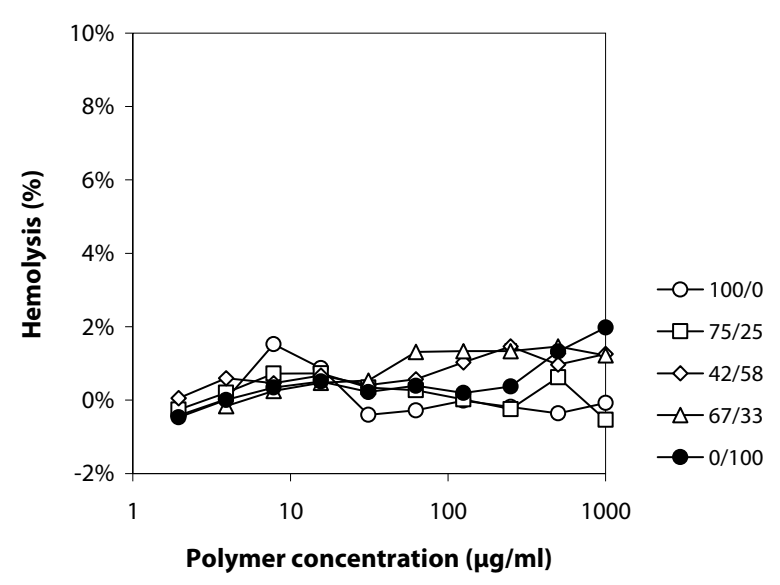

Figure 8.6: Hemoglobin leakage from human erythrocytes after 30 min incubation in $\mathrm{p}(\mathrm{CBA}-\mathrm{ABOL} / \mathrm{Nic})$ polymer solutions. systems, intense interactions have also the risk of damaging the cell membranes, resulting in cytotoxic side effects. The compatibility of the polymers with cell membranes was investigated against human erythrocytes by testing their hemolytic activity as a function of the polymer concentration. The hemolysis, defined as the release of hemoglobin, is plotted as a function of the polymer concentration in 
Figure 8.6. None of the polymers was observed to be hemolytic up to concentrations of I $\mathrm{mg} / \mathrm{ml}$. In chapter 3 it was already concluded that hemolysis primarily resulted from the primary or secondary amines of EDA or TETA functionalities and not from the lipophilic butanol side chains. Although the nicotinamide functionality contains a permanent cationic charge, it is dissipated over the aromatic ring by its $\pi$-electrons, resulting in a soft (polarizable) cationic character, that is more compatible with a lipid environment than hard (non-polarizable) ammonium ions. The absence of hemolysis on $\mathrm{p}(\mathrm{CBA}-\mathrm{ABOL} / \mathrm{Nic})$, indicating less disruptive membrane activity, is a great advantage over the former $\mathrm{p}$ (CBA-ABOL/EDA) siRNA delivery system.
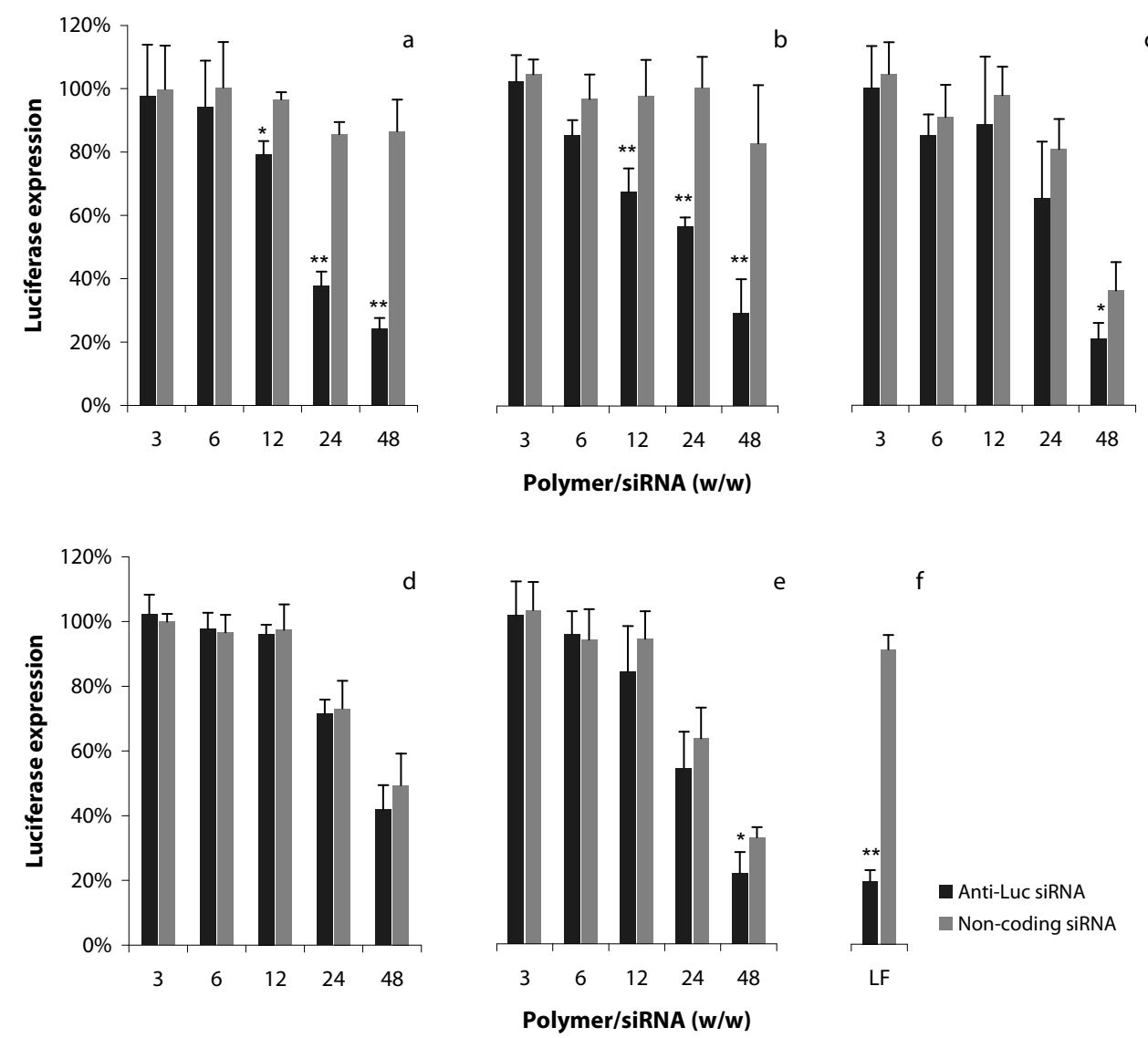

Figure 8.7: Luciferase expression of $\mathrm{H} 1299$ Fluct cells 48 hours after transfection with anti-luciferase siRNA (black) and non-coding control siRNA (grey) with $\mathrm{p}(\mathrm{CBA}-\mathrm{ABOL} / \mathrm{Nic}$ ) with ABOL/Nicotinamide ratios of 100/0 (a), 75/25 (b), 42/58 (c), 33/67 (d) and 0/100 (e). Lipofectamine 2000 (LF) was used as reference transfection agent (f). Each bar value represents the mean $\pm S D$ of $n=3,4$ or 5 . For statistical analysis of differences between antiluciferase and non-coding siRNA an unpaired Student's t-test was used $\left({ }^{*} \mathrm{p}<0.05 ;{ }^{* *} \mathrm{p}<0.01\right)$.

$158 \cdot$ Chapter 8 


\subsubsection{In vitro gene silencing}

To evaluate the silencing potential of the polymers Hi299 cells were used, which stably express luciferase. Polyplexes of five different polymer/siRNA weight ratios were prepared with anti-luciferase siRNA and with a non-coding control siRNA, respectively. After incubation of the Hi299 cells with these polyplexes for two hours, luciferase expressions were determined after 48 hours by measuring the intensity of emitted light in the enzyme-substrate reaction in the cell lysates mixed with luciferin. The results are plotted in Figure 8.7. Significant silencing was only observed for the p(CBA-ABOL) reference polymer with a knockdown of around $70 \%$ (corresponding with a remaining luciferase expression of $30 \%$ ), comparable to Lipofectamine 2000 (Figure $8.7 \mathrm{f}$ ).

Quite unexpectedly, all polyplexes with nicotinamide-containing polymers did not show any silencing. To verify cellular uptake of these particles, fluorescein labeled siRNA, complexed at 24/I polymer/siRNA weight ratio, was used for transfection of the Hi299 cells and analysed by flow cytometry immediately after 2 hours incubation with the polyplexes.

a

b
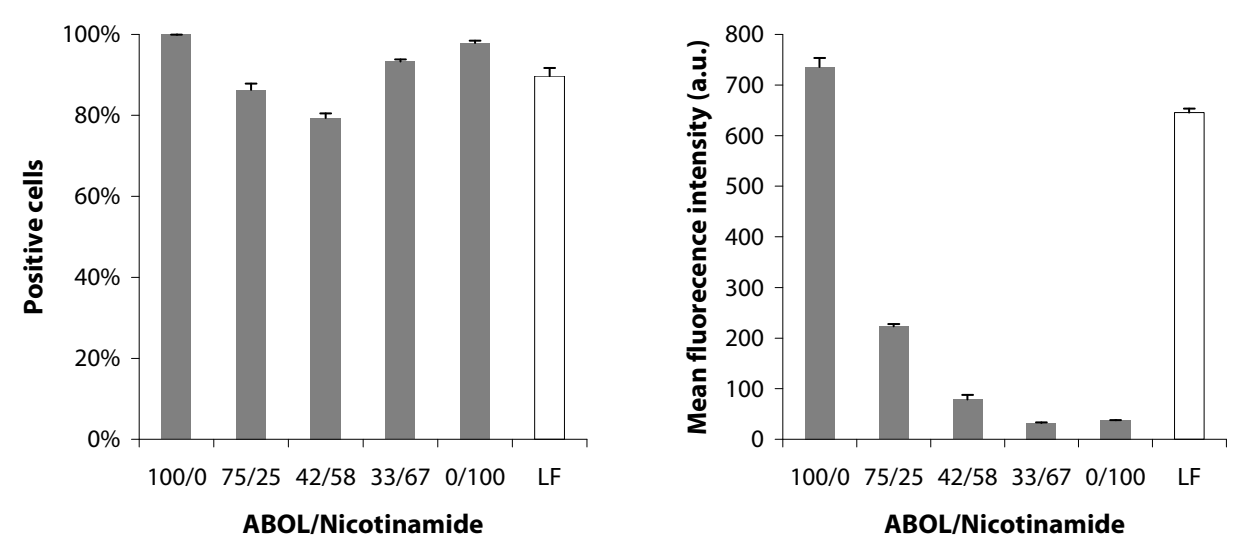

Figure 8.8: Uptake of fluorescein labeled siRNA complexed by $p(C B A-A B O L / N i c)$ copolymers in a polymer/siRNA weight ratio $24 / 1$ in H1299 cells: positive gated cells (a) and the mean fluorescence intensity per cell (b). Lipofectamine 2000 (LF) was used as reference transfection agent.

For all polymers a high uptake of 80 to 100\% positive cells was found, indicating successful delivery of polyplexes inside the cells (Figure $8.8 \mathrm{a}$ ). The mean fluorescence intensity per cell (Figure $8.8 \mathrm{~b}$ ) was however significantly lower for cells transfected with the nicotinamide-containing polymers than for the pure $\mathrm{p}(\mathrm{CBA}-\mathrm{ABOL})$ polymer, with a decreasing intensity with an increased nicotinamide content in the polymer. Thus, at first sight, it could be concluded that a lower polyplex uptake as a result of a lower 
$\mathrm{ABOL}$ content in the polymer could be the reason for the absence of gene silencing. However, such conclusion would contradict with the successful gene expression that is obtained with $\mathrm{p}\left(\mathrm{CBA}-\mathrm{ABOL}_{75} / \mathrm{Nic}_{25}\right)$ and $\mathrm{p}\left(\mathrm{CBA}-\mathrm{ABOL}_{42} / \mathrm{Nic}_{58}\right)$ polyplexes using plasmid DNA where the presence of quaternary nicotinamide groups showed to be advantageous (vide infra). Therefore, other factors should be taken into consideration. It is known that fluorescence can be quenched inside a polyplex [21]. Furthermore, it is possible that also the quaternized nicotinamide moieties contribute to the quenching of the fluorescence of fluorescein. Therefore, the fluorescence of free and complexed fluorescein labeled siRNA was determined in a separate experiment.
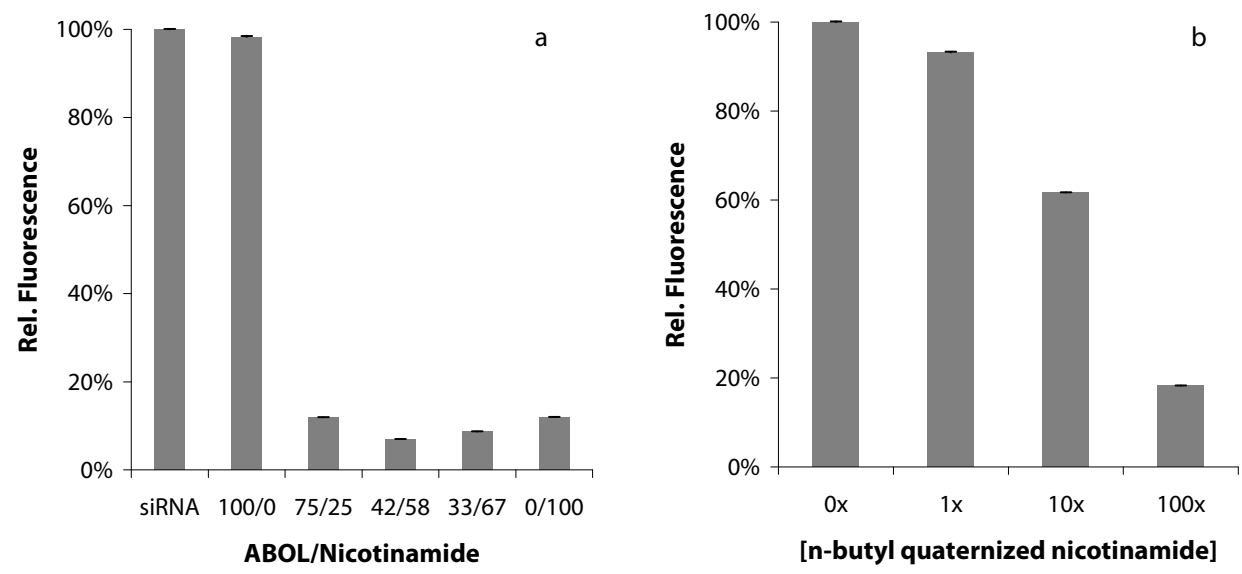

Figure 8.9: Relative fluorescence of fluorescein labeled siRNA: complexed in the different $p(C B A-A B O L / N i c)$ polyplexes prepared in a $24 / 1$ polymer/siRNA weight ratio (a) or in presence of $N$-butyl quaternized nicotinamide where $1 x$ concentration corresponds to the molar concentration of quaternized nicotinamide in $\mathrm{p}\left(\mathrm{CBA}-\mathrm{ABOL} / \mathrm{Nic}_{100}\right)$ polyplexes in a polymer/siRNA weight ratio $24 / 1$ (b).

From Figure 8.9a it becomes clear that indeed the presence of quaternized nicotinamide dramatically quenches the fluorescence (shifts in excitation and emission wavelengths were not observed, data not shown). It is apparent that the quenching is dependent on the local concentration of nicotinamide, which is logically lower when polyplexes are (partially) degraded intracellular. This is proved by the fluorescence of fluorescein labeled siRNA in the presence of different concentrations of $N$-butyl quaternized nicotinamide, that serves as a model for the degraded polymer fragments (Figure 8.9b). It is not clear for these polymers at which timescale the polymers degrade intracellularly, but it is reasonable to assume that immediately after incubation, the polyplexes are not completely degraded and the fluorescence can have been quenched indeed. Most quenching is then expected for the most stable particles, since the highest local concentration of quaternized nicotinamide is expected there. This is properly reflected by the increasing amount of nicotinamide in the polymer. In summary, from

$160 \cdot$ Chapter 8 
the lower fluorescence intensities observed in the flow cytometry experiments and since the gene expression after pDNA transfection with similar particles is excellent (vide infra), it cannot be concluded that the nicotinamide-containing polyplexes are taken up by the cells to a lower degree than pure $\mathrm{p}(\mathrm{CBA}-\mathrm{ABOL})$ polyplexes. It is hypothesized that the reason for the absence of gene silencing is originating in the specific RNAi pathway where the quaternary nicotinamide moieties from degraded polymer fragments are still intercalating in the double stranded siRNA, thereby inhibiting the uptake of siRNA in the dicer or RISC complex and the silencing process. However, verification of this assumption needs more detailed cell biology research.

\subsubsection{In vitro gene expression with pDNA polyplexes}

It was previously discovered that quaternary nicotinamide-containing poly(amido amine)s are promising candidates as vectors for the delivery of pDNA, resulting in high gene expressions [I6]. For that reason we have evaluated in this study our synthesized polymers also with polyplexes with a plasmid DNA encoding for green fluorescent protein (GFP) in COS-7 cells. Cell viability after polyplex treatment was assessed by a cell proliferation assay, based on XTT. The GFP expression induced by the different polyplexes was determined two days after incubation and was related to that caused by the use of linear PEI (Exgen 500) and plotted in Figure 8.roa together with cell viability. $\mathrm{p}(\mathrm{CBA}-\mathrm{ABOL})$ showed only high gene expressions at the highest polymer/pDNA weight ratio (48/I), which is in agreement with the results published previously [3]. However, notably higher efficiencies were obtained with the $25 \%$ nicotinamide-containing polymer, even when only half of the polymer dose was applied (i.e. polymer/pDNA ratio 24/I). Polymers having a nicotinamide content of $58 \%$ also showed a significantly higher gene expression than Exgen 500 and p(CBA-ABOL) at 24/I ratio. Higher nicotinamide contents in the polymer were not effective and even reduced the transfection efficiency. The decrease of the amount of $\mathrm{ABOL}$ functionality in these polymers may reduce cellular uptake, or intercalating polymer fragments may interfere with the DNA transcription, as was also postulated as a possible reason for the lack of gene silencing with these polymers. For all these polymers almost no cytotoxicity was observed with cell viabilities between $80 \%$ and $100 \%$.

For a good comparison with the siRNA gene silencing studies, these pDNA transfections were also done in $\mathrm{H} \mathrm{I} 299$ cells, using $\mathrm{p}(\mathrm{CBA}-\mathrm{ABOL})$ and $\mathrm{p}(\mathrm{CBA}-$ $\left.\mathrm{ABOL}_{75} / \mathrm{Nic}_{25}\right)$ (Figure 8.rob). The obtained results with $\mathrm{p}(\mathrm{CBA}-\mathrm{ABOL})$ are fully comparable with the transfection properties in COS-7 cells. The transfection of $\mathrm{p}$ (CBA$\mathrm{ABOL}_{75} / \mathrm{Nic}_{25}$ ) is comparable as well, but maximum transfection is there found at the lower polymer/pDNA weight ratio of $\mathrm{I} 2 / \mathrm{I}$. Based on these results, it remains difficult to explain why polyplexes containing $25 \%$ of nicotinamide perform excellent in inducing 
gene expression, but lack the ability to induce gene silencing. If remaining intercalation of polymer fragments in siRNA is the reason of inactivity in the gene silencing process, this phenomenon is apparently less prohibitive in the gene transcription process. Intercalation may there primarily occur in non-essential parts of the DNA plasmid or the intercalating moieties may have been expelled once the DNA-polymerase enzyme starts transcription of the plasmid. The lower gene expressions that are observed for polymers with higher nicotinamide content are in agreement with this assumption, but may also be caused by a lower cellular uptake as a result of an unfavorable shift in the hydrophilicity-lipophilicity balance due to the decrease of the ABOL content in the polymer.
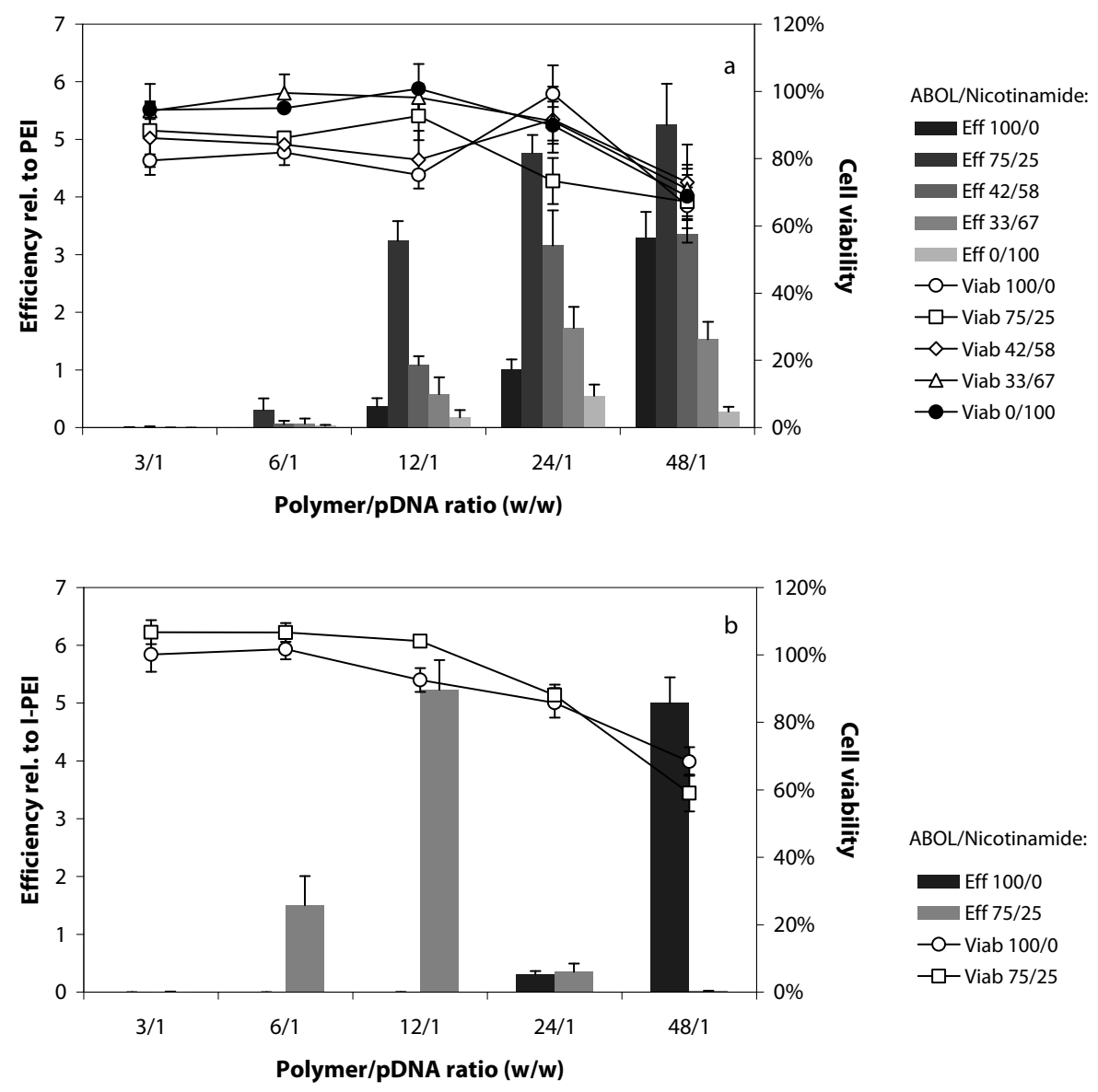

Figure 8.10: Transfection efficiencies (GFP expression, bars) and cell viabilities (lines) after polyplex incubation and 48 hours after transfection relative to I-PEI (Exgen 500) with p(CBA-ABOL/Nic) copolymers in COS-7 cells (a) and in $\mathrm{H} 1299$ cells (b). Cell viability of Exgen 500 treated cells showed a viability of $64 \pm 4 \%$ and $82 \pm 4 \%$ in COS-7 cells and H1299 cells, respectively. Each data point represents the mean \pm SD of $n=4$ or 5 . 


\subsection{Conclusions}

The incorporation of intercalating quaternary nicotinamide groups in the side chains of SS-PAA gene carrier polymers is an attractive alternative for high cationic charge densities to obtain stable polyplexes. The introduction of only $25 \%$ of these nicotinamide groups onto a $\mathrm{p}(\mathrm{CBA}-\mathrm{ABOL})$ polymer by a Zincke grafting turned out to be sufficient to reduce the amount of polymer needed to encapsulate both siRNA as pDNA into small polyplexes. Moreover, none of the polymers was hemolytic up to concentrations of $\mathrm{I} \mathrm{mg} / \mathrm{ml}$. Although the lack of gene silencing activity of siRNA polyplexes with these polymers was unexpected and not fully elucidated, pDNA polyplexes of these polymers proved to be powerful candidates in inducing gene (GFP) expression without any notable cytotoxicity. The presence of $25 \%$ of nicotinamide was found to be optimal and induced high GFP expressions of about $4-5$ times that of linear PEI in COS-7 and Hı299 cells. This was comparable with p(CBA-ABOL), but it could be achieved with twofold and fourfold lower polymer doses in COS-7 and Hi299 cells, respectively. To this end the development of these $\mathrm{p}(\mathrm{CBA}-\mathrm{ABOL} / \mathrm{Nic})$ copolymers can be considered as an important improvement of our existing $\mathrm{p}(\mathrm{CBA}-\mathrm{ABOL})$ transfection system.

\subsection{Acknowledgement}

Thanks to Gijs den Besten and Thomas Hartjes for doing explorative work on the nicotinamide-containing polymers.

\subsection{References}

I. Gary, D.J., N. Puri, and Y.-Y. Won, Polymer-based siRNA delivery: Perspectives on the fundamental and phenomenological distinctions from polymer-based DNA delivery. Journal of Controlled Release, 2007. I2I(I-2): p. 64-73.

2. Kim, W.J. and S.W. Kim, Efficient siRNA Delivery with Non-viral Polymeric Vehicles. Pharmaceutical Research, 2009. 26(3): p. 657-666.

3. Lin, C., et al., Novel Bioreducible Poly(amido amine)s for Highly Efficient Gene Delivery. Bioconjugate Chemistry, 2007. I8(I): p. I38-I45.

4. Lin, C., et al., Bioreducible poly(amido amine)s with oligoamine side chains: Synthesis, characterization, and structural effects on gene delivery. Journal of Controlled Release, 2008. 126(2): p. I66-174.

5. $\quad$ Piest, M., et al., Novel poly(amido amine)s with bioreducible disulfide linkages in their diamino-units: Structure effects and in vitro gene transfer properties. Journal of Controlled Release, 2008. 130(I): p. 38-45.

6. Spagnou, S., A.D. Miller, and M. Keller, Lipidic carriers of siRNA: Differences in the formulation, cellular uptake, and delivery with plasmid DNA. Biochemistry, 2004. 43(42): p. I3348-I3356. 
7. Lv, H.T., et al., Toxicity of cationic lipids and cationic polymers in gene delivery. Journal of Controlled Release, 2006. II4(I): p. Ioo-Io9.

8. Boussif, O., et al., $A$ Versatile Vector for Gene and Oligonucleotide Transfer into Cells in Culture and in-Vivo - Polyethylenimine. Proceedings of the National Academy of Sciences of the United States of America, I995. 92(I6): p. 7297-730I.

9. Neto, B.A.D. and A.A.M. Lapis, Recent Developments in the Chemistry of Deoxyribonucleic Acid (DNA) Intercalators: Principles, Design, Synthesis, Applications and Trends. Molecules, 2009. I4(5): p. I725-I746.

Io. Ihmels, H. and D. Otto, Intercalation of organic dye molecules into doublestranded DNA general principles and recent developments, in Supermolecular Dye Chemistry. 2005. p. I6I-204.

II. Baumhover, N.J., et al., Synthesis and In Vitro Testing of New Potent Polyacridine-Melittin Gene Delivery Peptides. Bioconjugate Chemistry, 20 o. 2I(I): p. 74-83.

I2. Fernandez, C.A., et al., Discovery of Metabolically Stabilized Electronegative Polyacridine-PEG Peptide DNA Open Polyplexes. Bioconjugate Chemistry, 20I0. 2I(4): p. 723-730.

I3. Shiraishi, T., R. Hamzavi, and P.E. Nielsen, Targeted delivery of plasmid DNA into the nucleus of cells via nuclear localization signal peptide conjugated to DNA intercalating bis- and trisacridines. Bioconjugate Chemistry, 2005. I6(5): p. III2-III6.

I4. Boulanger, C., C. Di Giorgio, and P. Vierling, Synthesis of acridine-nuclear localization signal (NLS) conjugates and evaluation of their impact on lipoplex and polyplex-based transfection. European Journal of Medicinal Chemistry, 2005. 40(I2): p. I295-I306.

15. Zhang, H.W., A. Mitin, and S.V. Vinogradov, Efficient Transfection of BloodBrain Barrier Endothelial Cells by Lipoplexes and Polyplexes in the Presence of Nuclear Targeting NLS-PEG-Acridine Conjugates. Bioconjugate Chemistry, 2009. 20(I): p. I20-I28.

I6. Mateos-Timoneda, M.A., et al., Poly(amido amine)s as Gene Delivery Vectors: Effects of Quaternary Nicotinamide Moieties in the Side Chains.

ChemMedChem, 2007. 3: p. 478-486.

I7. Ferguson, L.R. and W.A. Denny, Genotoxicity of non-covalent interactions: DNA intercalators. Mutation Research-Fundamental and Molecular Mechanisms of Mutagenesis, 2007. 623(I-2): p. I4-23.

I8. Lettre, H., W. Haede, and E. Ruhbaum, Zur Darstellung Von Derivaten Des Nicotinsaureamids. Annalen Der Chemie-Justus Liebig, I953. 579(2): p. I23-I32.

I9. Meyer, M., et al., A dimethylmaleic acid - melittin-polylysine conjugate with reduced toxicity, $\mathrm{pH}$-triggered endosomolytic activity and enhanced gene transfer potential. Journal of Gene Medicine, 2007. 9(9): p. 797-805.

20. Cheng, W.C. and M.J. Kurth, The Zincke reaction. A review. Organic Preparations and Procedures International, 2002.34(6): p. 585-608.

2I. Vader, P., et al., A method for quantifying cellular uptake of fluorescently labeled siRNA. Journal Of Controlled Release, 20I0. I48(I): p. Io6-Io9. 


\title{
Chapter
}

\section{Intercalating poly(amido amine)s for gene delivery based on quaternary nicotinamide derivatives}

\author{
L.J. van $\operatorname{der} A a$ \\ P. Vader \\ R.M. Schiffelers \\ G. Storm \\ J.F.J. Engbersen
}




\begin{abstract}
We have synthesized four reducible poly(amido amine)s containing structurally related quaternary nicotinamide moieties as side groups for the complexation of siRNA and pDNA. The intercalation interaction was tuned by the use of nicotinamides that were $N$-alkylated or $N$-phenylated via the amide functionality. Especially at low polymer/nucleotide weight ratios, the strongly intercalating nicotinamide (Nic) and $\mathrm{N}$ phenylnicotinamide $(\mathrm{NicPh})$ side groups were found to contribute significantly to the formation of small and cationic polyplexes. At higher polymer amounts this effect is overshadowed by the electrostatic interactions between the cationic polymer and the nucleotide. Gene silencing was only observed with polyplexes of polymers having the strongest intercalating sidegroup (NicPh). In pDNA transfection (GFP expression), the ability to intercalate turned out to be highly beneficial at low polymer/pDNA weight ratios, resulting in GFP expressions that were up to sixfold higher than were obtained with linear PEI, in absence of cytotoxicity. In general the cytotoxicity of the cationic quaternized nicotinamide derivatives was found to be lower than for polymers containing cationic primary amino groups.
\end{abstract}

\title{
9.1 Introduction
}

In the previous chapter we described a novel class of bioreducible poly(amido amine) polymers (SS-PAAs) that can form stable polyplexes with oligo- and polynucleotides, based on intercalation interactions induced by quaternary nicotinamide side groups in the polymer. The use of intercalative interactions, as described in Chapter 8 (Figure 8.I), can be a good alternative for electrostatic interactions to improve polymer / nucleotide binding, since a high density of cationic charge in a polymeric gene vector frequently effectuates toxic side effects. It was demonstrated that a ratio of $75 \%$ hydroxybutyl (ABOL) and $25 \%$ quaternary nicotinamide sidegroups in the $\mathrm{p}(\mathrm{CBA}-\mathrm{ABOL} / \mathrm{Nic})$ copolymer forms an optimal combination to obtain small polyplexes with siRNA and pDNA. Although the siRNA polyplexes of this polymer did not induce gene silencing, the pDNA loaded polyplexes induced an excellent GFP expression. In a recent study of our lab, it was found that quaternized nicotinamide is capable to intercalate between the base pairs of DNA. Furthermore, the quaternary nicotinamide was found to be very biocompatible, since it is only a weak intercalator and part of the naturally occurring and omnipresent coenzyme NAD ${ }^{+}[\mathrm{I}]$.

In this study we have synthesized a number of copolymers with quaternized nicotinamide groups that are differently substituted at the amide nitrogen (Scheme 9.I) to investigate the intercalation properties in more detail and their effects on polyplex

$166 \cdot$ Chapter 9 
formation and transfection. Nicotinamides with alkyl substituents at the amide (NicMe and $\mathrm{NicEt}_{2}$ ) were selected to reduce the number of hydrogen bond donation sites and are expected to weaken the intercalation strength. A phenyl substituent (NicPh) was chosen for its increased hydrophobic character and additional $\pi$-stacking capacity with the bases of the nucleotides. The selected nicotinamide derivatives were coupled to the polymer by the Zincke reaction with primary amines and the resulting polymers were tested as vectors in siRNA and pDNA transfections in Hi299 and COS-7 cells.

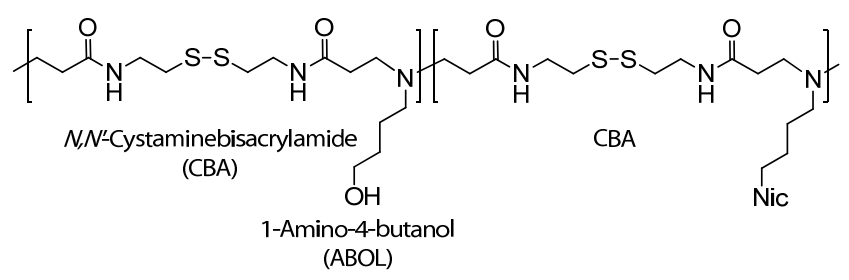

Nic:<smiles>CCN(CC)C(=O)c1ccc[n+](C)c1</smiles>

$N, N$-Diethylnicotinamide $\left(\mathrm{NicEt}_{2}\right)$<smiles>CNC(=O)c1ccc[n+](C)c1</smiles>

N-Methylnicotinamide (NicMe)<smiles>C[n+]1cccc(C(N)=O)c1</smiles>

Nicotinamide (Nic)

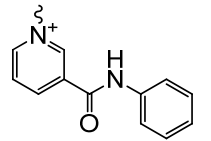

$N$-Phenylnicotinamide (NicPh)

Scheme 9.1: Schematic representation of the poly(CBA-ABOL/Nic) copolymer. The different quaternary sidegroups are attached on the polymer structure at the position marked with 'Nic'. The selected sidegroups, including their names and the used abbreviations are displayed as well.

\subsection{Materials and methods}

\subsubsection{Materials}

All chemicals and reference materials, nicotinamide (Fluka), pyridine (Acros), $\mathrm{N}$ methylnicotinamide (TCl Europe), N,N-diethylnicotinamide (Aldrich), $\quad N$ phenylnicotinamide (Aldrich), n-butylamine (Aldrich), I-bromobutane (Acros), I-chloro2,4-dinitrobenzene (Acros), 4-amino-I-butanol (ABOL, Merck), N-Boc-I,4diaminobutane (NHBoc, Fluka), N,N'-cystaminebisacrylamide (CBA, Polysciences), sodium 3'-[I-phenylamino-carbonyl]-3,4-tetrazolium]-bis[4-methoxy-6nitro]benzenesulfonic acid hydrate (XTT, Polysciences), phenazine methosulfate (PMS, Aldrich), branched poly(ethylene imine) (25 kg/mol, Aldrich), Exgen 500 (Fermentas) and Lipofectamine 2000 (Invitrogen) were purchased in the highest purity and used without further purification. For culturing the Hi299 Fluct cells RPMI I640 medium (Lonza) 
completed with $2 \%(\mathrm{v} / \mathrm{v})$ PennStrepp (Lonza), I\% (v/v) glutamine (Lonza) and Io\% (v/v) fetal bovine serum (Lonza) was used. COS-7 cells were cultured in DMEM containing $4.5 \mathrm{~g} / \mathrm{l}$ of glucose (Gibco), completed with completed with $2 \%$ (v/v) PennStrepp (Lonza), I\% (v/v) glutamine (Lonza) and Io\% (v/v) fetal bovine serum (Lonza). Negative control siRNA was purchased from Qiagen, anti-luciferase siRNA was kindly supplied by the University of Utrecht and the plasmid pCMV-GFP was purchased from Plasmid Factory (Bielefeld, Germany). Luciferase assay reagent was obtained from Promega.

\subsubsection{Synthesis of the Zincke salts}

\section{$N, N$-Diethylnicotinamide Zincke salt}

The Zincke salt of $N, N$-diethylnicotinamide was synthesized according to a slightly modified literature procedure [2]. $13.7 \mathrm{~g}(67.5 \mathrm{mmol}, 3 \mathrm{eq})$ of I-chloro-2,4-dinitrobenzene was dissolved in $30 \mathrm{ml}$ of acetone and $4.0 \mathrm{~g}(22.5 \mathrm{mmol}$, I eq) of $N, N$ diethylnicotinamide was added subsequently. After refluxing the solution for 48 hours, it was precipitated in diethyl ether twice. The precipitate was dissolved in $100 \mathrm{ml}$ of water and treated with activated carbon. After filtration, water was evaporated under reduced pressure and the Zincke salt was obtained as a yellow crystalline material. Yield: 5.92g (68\%). ${ }^{\mathrm{H}} \mathrm{H} \mathrm{NMR}\left(\mathrm{D}_{2} \mathrm{O}\right) \delta(\mathrm{ppm})$ : I.I4-I.22 (dt, $\left.6 \mathrm{H}, \mathrm{CON}\left(\mathrm{CH}_{2} \mathrm{CH}_{3}\right)_{2}\right) ; 3.37-3.57$ (dq, ${ }_{4} \mathrm{H}$, $\left.\mathrm{CON}\left(\mathrm{CH}_{2} \mathrm{CH}_{3}\right)_{2}\right) ; 8.25$ (d, IH, CCHCHCNO$\left.{ }_{2}\right) ; 8.44$ (t, $\left.\mathrm{IH}, \mathrm{CHCHCCO}\right) ; 8.89$ (d, IH, $\mathrm{CHCHCNO}_{2}$ ); 8.96 (d, IH, CHCHCCO); $9.26\left(\mathrm{~d}, \mathrm{IH}, \mathrm{CHCHN} \mathrm{N}^{+}\right) ; 9.36(\mathrm{~s}, \mathrm{IH}$, $\left.\mathrm{CNO}_{2} \mathrm{CHCNO}_{2}\right) ; 9.44\left(\mathrm{~s}, \mathrm{IH}, \mathrm{N}^{+} \mathrm{CHCCO}\right.$ ).

\section{$\mathbf{N}$-Methylnicotinamide Zincke salt}

The Zincke salt of $N$-methylnicotinamide was synthesized according to a literature procedure [3]. $4.0 \mathrm{~g}(29.4 \mathrm{mmol}$, I eq) of nicotinamide was added to I9.9 $\mathrm{g}(98.3 \mathrm{mmol}, 3$ eq) of molten I-chloro-2,4-dinitrobenzene and stirred at $100^{\circ} \mathrm{C}$. After I hour the flask was cooled to room temperature, the obtained yellow to brown solid was dissolved in 30 $\mathrm{ml}$ of methanol, followed by precipitation in diethyl ether thrice. The precipitate was dissolved in $100 \mathrm{ml}$ of water and treated with activated carbon. After filtration, water was evaporated under reduced pressure and the Zincke salt was obtained as a yellow crystalline material. Yield: 5.5Ig (55\%). ${ }^{\mathrm{H}} \mathrm{H}$ NMR $\left(\mathrm{D}_{2} \mathrm{O}\right) \delta(\mathrm{ppm}): 2.96\left(\mathrm{~s}, 3 \mathrm{H}, \mathrm{CONHCH} \mathrm{CH}_{3}\right.$; 8.2I (d, IH, CCHCHCNO${ }_{2}$ ); 8.42 (t, IH, CHCHCCO); 8.9I (d, IH, CHCHCNO $\mathrm{IH}, \mathrm{CHCHCCO}$ ); 9.28 (d, IH, CHCHN $\left.{ }^{+}\right) ; 9.36$ (s, IH, $\mathrm{CNO}_{2} \mathrm{CHCNO}_{2}$ ); 9.57 (s, IH, $\mathrm{N}^{+} \mathrm{CHCCO}$ ).

$168 \cdot$ Chapter 9 


\section{Nicotinamide Zincke salt}

A detailed description of the synthesis of the Zincke salt of nicotinamide can be found in chapter 7 of this thesis.

\section{N-Phenylnicotinamide Zincke salt}

The Zincke salt of $N$-phenylnicotinamide was synthesized from $2.0 \mathrm{~g}$ (Io.I mmol, I eq) $N$-phenylnicotinamide and $6.14 \mathrm{~g}(30.3 \mathrm{mmol}, 3 \mathrm{eq})$ I-chloro-2,4-dinitrobenzene under the same conditions as described for the $N$-methylnicotinamide Zincke salt without the active carbon treatment, employing $N$-phenylnicotinamide instead of $N$ methylnicotinamide. Yield: $3.29 \mathrm{~g}(8 \mathrm{r} \%) .{ }^{\mathrm{I}} \mathrm{H}$ NMR $\left(\mathrm{D}_{2} \mathrm{O}\right) \delta(\mathrm{ppm}): 7.30 \quad(\mathrm{t}, \quad \mathrm{IH}$, $\mathrm{NHCCHCHCHCHCH}) ; \quad 7.45$ (t, $2 \mathrm{H}, \quad \mathrm{NHCCHCHCHCHCH}) ; \quad 7.55 \quad(\mathrm{~d}, \quad 2 \mathrm{H}$, $\mathrm{NHCCHCHCHCHCH}$ ); 8.25 (d, IH, CCHCHCNO 2 ); 8.47 (t, IH, CHCHCCO); 8.89 (d, $\mathrm{IH}, \mathrm{CH} C H \mathrm{CNO}_{2}$ ); 9.32 (d, 2H, CHCHCHCCO); 9.36 (s, IH, $\mathrm{CNO}_{2} C H \mathrm{CNO}_{2}$ ); 9.69 (s, IH, $\mathrm{N}^{+} \mathrm{CHCCO}$ ).

\subsubsection{Synthesis n-butyl quaternary nicotinamide derivatives}

\section{1-Butylpyridinium bromide (BuPyr)}

I.o $\mathrm{ml}$ (I2.7 mmol, I eq) of pyridine was dissolved in $15 \mathrm{ml}$ of acetonitril and $4.1 \mathrm{ml}$ ( $38.0 \mathrm{mmol}, 3 \mathrm{eq}$ ) of I-bromobutane was added dropwise. After $2 \mathrm{oh}$ of refluxing, the solution was concentrated and the product was precipitated by addition of cold acetone. The obtained white crystals were collected by filtration, washed extensively with acetone and dried under vacuum. Yield: $\mathrm{I} .32 \mathrm{~g}(48 \%)$. ${ }^{\mathrm{H}} \mathrm{H} \mathrm{NMR}\left(\mathrm{D}_{2} \mathrm{O}\right) \delta(\mathrm{ppm}): 0.90\left(\mathrm{t},{ }_{3} \mathrm{H}\right.$, $\left.\mathrm{CH}_{3}\right)$; I.3I (m, $\left.2 \mathrm{H}, \mathrm{CH}_{2} \mathrm{CH}_{3}\right) ; \mathrm{I} .96\left(\mathrm{~m}, 2 \mathrm{H}, \mathrm{CH}_{2} \mathrm{CH}_{2} \mathrm{~N}^{+}\right) ; 4.58\left(\mathrm{t}, 2 \mathrm{H}, \mathrm{CH}_{2} \mathrm{~N}^{+}\right) ; 8.03(\mathrm{t}, 2 \mathrm{H}$, $\mathrm{CHCHCHCHCH}) ; 8.50(\mathrm{t}, \mathrm{IH}, \mathrm{CHCHCHCHCH}) ; 8.82(\mathrm{~d}, 2 \mathrm{H}, \mathrm{CHCHCHCHCH})$.

\section{1-Butyl-N, N-diethyl-3-carbamoylpyridinium chloride (BuNicEt ${ }_{2}$ )}

$0.5 \mathrm{~g}$ (I.3 mmol, I eq) of $N, N$-diethylnicotinamide Zincke salt was dissolved in $5 \mathrm{ml}$ of methanol. After the subsequent addition of $0.26 \mathrm{ml}$ ( $2.6 \mathrm{mmol}, 2 \mathrm{eq})$ of $\mathrm{n}$-butylamine, the color of the solution changed from yellow into deep red immediately. After the solution turned yellow again, indicating that the reaction was completed, methanol and the excess of $n$-butylamine were removed by evaporation. The yellow residue was dissolved in methanol again and triturated with $60 \mathrm{ml}$ of water to precipitate the 2,4dinitroaniline byproduct. The yellow precipitate was removed by filtration and active carbon was added until all residual yellow color had disappeared. Active carbon was 
removed by filtration and the product was isolated as a white material by lyophilization. Yield: 0.33 g (55\%). ${ }^{\mathrm{H}} \mathrm{H}$ NMR $\left(\mathrm{D}_{2} \mathrm{O}\right) \delta(\mathrm{ppm})$ : 0.9I (t, $\left.3 \mathrm{H}, \boldsymbol{C H}_{3}\right)$; I.II-I.22 (dt, $6 \mathrm{H}$, $\left.\mathrm{CON}\left(\mathrm{CH}_{2} \mathrm{CH}_{3}\right)_{2}\right) ; \mathrm{I} .34\left(\mathrm{~m}, 2 \mathrm{H}, \mathrm{CH}_{2} \mathrm{CH}_{3}\right) ; \mathrm{I} .97\left(\mathrm{~m}, 2 \mathrm{H}, \mathrm{CH}_{2} \mathrm{CH}_{2} \mathrm{~N}^{+}\right) ; 3.26-3.53(\mathrm{dq}, 4 \mathrm{H}$, $\left.\mathrm{CON}\left(\mathrm{CH}_{2} \mathrm{CH}_{3}\right)_{2}\right) ; 4.63\left(\mathrm{t}, 2 \mathrm{H}, \mathrm{CH}_{2} \mathrm{~N}^{+}\right) ; 8.14$ (t, IH, $\mathrm{CHCHCCO}$ ); 8.56 (d, IH, CHCHCCO);

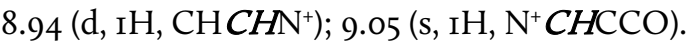

\section{1-Butyl- $\mathrm{N}$-methyl-3-carbamoylpyridinium chloride (BuNicMe)}

$0.5 \mathrm{~g}$ (I.5 mmol, I eq) of $\mathrm{N}$-methylnicotinamide Zincke salt was dissolved in $5 \mathrm{ml}$ of methanol. After the subsequent addition of $0.29 \mathrm{ml}$ (3.0 mmol, 2 eq) of n-butylamine, the color of the solution changed from yellow into deep red immediately. After the solution turned yellow again, indicating that the reaction was completed, it was triturated with diethyl ether to precipitate the product. The yellow precipitate was collected by filtration, dissolved in $\mathrm{I} 5 \mathrm{ml}$ of water and active carbon was added until all the yellow color was disappeared. Active carbon was removed by filtration and the product was isolated as a white crystalline material by lyophilization. Yield: o.Igg (31\%). ${ }^{\mathrm{I}} \mathrm{H}$ NMR $\left(\mathrm{D}_{2} \mathrm{O}\right) \delta(\mathrm{ppm}): 0.90\left(\mathrm{t}, 3 \mathrm{H}, \boldsymbol{C H}_{3}\right) ; \mathrm{I} .35\left(\mathrm{~m}, 2 \mathrm{H}, \mathrm{CH}_{2} \mathrm{CH}_{3}\right) ; \mathrm{I} .98(\mathrm{~m}, 2 \mathrm{H}$, $\left.\mathrm{CH}_{2} \mathrm{CH}_{2} \mathrm{~N}^{+}\right) ; 2.94\left(\mathrm{~s}, 4 \mathrm{H}, \mathrm{CONH} C_{3}\right) ; 4.64\left(\mathrm{t}, 2 \mathrm{H}, \mathrm{CH}_{2} \mathrm{~N}^{+}\right) ; 8.13(\mathrm{t}, \mathrm{IH}, \mathrm{CHCHCCO}) ; 8.77$ (d, $\mathrm{IH}, \mathrm{CH} C H \mathrm{CCO}) ; 8.96$ (d, IH, $\left.\mathrm{CHCHN}^{+}\right) ; 9.22\left(\mathrm{~s}, \mathrm{IH}, \mathrm{N}^{+} C H \mathrm{CCO}\right)$.

\section{1-Butyl-3-carbamoylpyridinium bromide (BuNic)}

I.o g ( $8.2 \mathrm{mmol}$, I eq) of nicotinamide was dissolved under reflux in $15 \mathrm{ml}$ of acetonitril and $2.7 \mathrm{ml}(24.6 \mathrm{mmol}, 3 \mathrm{eq})$ of I-bromobutane was added dropwise. After 2oh of refluxing, the precipitated white crystals were collected by filtration, washed extensively with acetonitril and dried under vacuum. Yield: $0.62 \mathrm{~g}(29 \%)$. ${ }^{\mathrm{H}} \mathrm{H}$ NMR $\left(\mathrm{D}_{2} \mathrm{O}\right)$ $\delta(\mathrm{ppm}): 0.9 \mathrm{I}\left(\mathrm{t}, 3 \mathrm{H}, \boldsymbol{C H}_{3}\right) ; \mathrm{I} .36\left(\mathrm{~m}, 2 \mathrm{H}, \boldsymbol{C H}_{2} \mathrm{CH}_{3}\right) ; \mathrm{I} .99\left(\mathrm{~m}, 2 \mathrm{H}, \boldsymbol{C H}_{2} \mathrm{CH}_{2} \mathrm{~N}^{+}\right) ; 4.66(\mathrm{t}, 2 \mathrm{H}$, $\left.\mathrm{CH}_{2} \mathrm{~N}^{+}\right) ; 8.15$ (t, IH, CHCHCCO); $8.86(\mathrm{~d}, \mathrm{IH}, \mathrm{CH} C H \mathrm{CCO}) ; 9.00\left(\mathrm{~d}, \mathrm{IH}, \mathrm{CH} C H \mathrm{~N}^{+}\right) ; 9.28$ $\left(\mathrm{s}, \mathrm{IH}, \mathrm{N}^{+} \mathrm{CHCCO}\right)$.

\section{1-Butyl-N-phenyl-3-carbamoylpyridinium chloride (BuNicPh)}

BuNicPh was synthesized from $0.5 \mathrm{~g}$ ( $1.3 \mathrm{mmol}$, I eq) $\mathrm{N}$-phenylnicotinamide Zincke salt and $0.25 \mathrm{ml}(2.5 \mathrm{mmol}, 2 \mathrm{eq}) \mathrm{n}$-butylamine under the same conditions as described for the BuNicMe, employing $N$-phenylnicotinamide Zincke salt instead of $N$ methylnicotinamide Zincke salt. Yield: o.29g (48\%). ${ }^{\mathrm{H}} \mathrm{H} \mathrm{NMR}\left(\mathrm{D}_{2} \mathrm{O}\right) \delta(\mathrm{ppm}): 0.92\left(\mathrm{t},{ }_{3} \mathrm{H}\right.$, $\left.C_{3}\right) ; \mathrm{I} .35\left(\mathrm{~m}, 2 \mathrm{H}, \boldsymbol{C H}_{2} \mathrm{CH}_{3}\right) ; 2.00\left(\mathrm{~m}, 2 \mathrm{H}, \boldsymbol{C H}_{2} \mathrm{CH}_{2} \mathrm{~N}^{+}\right) ; 4.67\left(\mathrm{t}, 2 \mathrm{H}, \boldsymbol{C H}_{2} \mathrm{~N}^{+}\right) ; 7.29$ (t, IH, $\mathrm{NHCCHCHCHCHCH}) ; \quad 7.45$ (t, $2 \mathrm{H}, \quad \mathrm{NHCCHCHCHCHCH}) ; \quad 7.53 \quad(\mathrm{~d}, \quad 2 \mathrm{H}$, 
$\mathrm{NHCCHCHCHCHCH}$ ); 8.17 (t, IH, CHCHCCO); 8.90 (d, IH, CHCHCCO); 8.99 (d, IH, $\mathrm{CHCH \textrm {N } ^ { + }}$ ); 9.34 (s, IH, $\mathrm{N}^{+} \mathrm{CHCCO}$ ).

\subsubsection{Synthesis of copolymers containing quaternary nicotinamide derivatives}

All polymers were synthesized from the same parent polymer $\mathrm{p}(\mathrm{CBA}$ $\left.\mathrm{ABOL}_{75} /\left(\mathrm{NH}_{2}\right)_{25}\right)$ containing $75 \%$ hydroxybutyl $(\mathrm{ABOL})$ and $25 \%$ aminobutyl $\left(\mathrm{NH}_{2}\right)$ sidegroups. This parent polymer was synthesized in a two step synthesis. Since this polymer has been described already in chapter 8 , the reader is referred to this chapter for a detailed description of the synthesis.

\section{p(CBA-ABOL/NicEt ${ }_{2}$ )}

Quaternary $N, N$-diethylnicotinamide functionalities were introduced on the primary amines of $\mathrm{p}\left(\mathrm{CBA}-\mathrm{ABOL}_{75} /\left(\mathrm{NH}_{2}\right)_{25}\right)$ via a Zincke reaction. Typically, $\mathrm{I5O} \mathrm{mg}$ of $\mathrm{p}\left(\mathrm{CBA}-\mathrm{ABOL}_{75} /\left(\mathrm{NH}_{2}\right)_{25}\right)$ (o.II mmol, I eq of primary amines) and $49 \mathrm{mg}$ (o.I5 mmol, I.2 eq) of $N, N$-diethylnicotinamide Zincke salt were dissolved in $1.5 \mathrm{ml}$ of methanol and stirred at room temperature. Drops of a methanolic sodium hydroxide solution were added until the color of the solution changed from yellow to deep red indicating that the Zincke reaction proceeded due to the deprotonation of the primary amines. After 2 hours of stirring, 2I $\mu \mathrm{l}$ (0.2I mmol, $2 \mathrm{eq}$ ) of $\mathrm{n}$-butylamine was added to finalize the reaction, yielding a yellow solution indicating that all the Zincke salt was converted. The 2,4-dinitroaniline by product was precipitated with $\mathrm{Io} \mathrm{ml}$ of water and removed by centrifugation and filtration through a $0.45 \mu \mathrm{m}$ syringe filter. The remaining polymer solution was finally purified by ultrafiltration (MWCO гоoо, $\left.\mathrm{pH}_{5}\right)$ and recovered as its $\mathrm{HCl}$ salt by lyophilization. Yield: $64 \mathrm{mg}(37 \%) ;{ }^{\mathrm{I}} \mathrm{H}$ NMR $\left(\mathrm{D}_{2} \mathrm{O}\right) \delta(\mathrm{ppm})$ : I.o8-I.I8 (dt, $6 \mathrm{H}$, $\left.\mathrm{CON}\left(\mathrm{CH}_{2} \mathrm{CH}_{3}\right)_{2}\right) ; \mathrm{I} .54\left(\mathrm{~m}, 2 \mathrm{H}, \boldsymbol{C H}_{2} \mathrm{CH}_{2} \mathrm{CH}_{2} \mathrm{OH}\right) ;$ I. 75 (m, $\left.2 \mathrm{H}, \mathrm{CH}_{2} \mathrm{CH}_{2} \mathrm{OH}\right) ; \mathrm{I} .83(\mathrm{~m}, 2 \mathrm{H}$, $\left.\mathrm{CH}_{2} \mathrm{CH}_{2} \mathrm{CH}_{2} \mathrm{~N}^{+}\right) ; 2.08\left(\mathrm{~m}, 2 \mathrm{H}, \mathrm{CH}_{2} \mathrm{CH}_{2} \mathrm{~N}^{+}\right) ; 2.73(\mathrm{t}, 2 \mathrm{H}, \mathrm{NHCOCH})_{2} ; 2.79(\mathrm{t}, 4 \mathrm{H}$, $\mathrm{CH}_{2} \mathrm{SSCH}_{2}$ ); $3.20\left(\mathrm{t}, 2 \mathrm{H}, \mathrm{CH}_{2} \mathrm{CH}_{2} \mathrm{CH}_{2} \mathrm{NR}_{2}\right) ; 3.4 \mathrm{I}\left(\mathrm{t}, 4 \mathrm{H}, \mathrm{CH}_{2} \mathrm{NRCH}\right) ; 3.47(\mathrm{t}, 4 \mathrm{H}$, NHCH $\left.\mathrm{CH}_{2} \mathrm{SSCH}_{2} \mathrm{CH}_{2} \mathrm{NH}\right) ; 3.52\left(\mathrm{~m}, 4 \mathrm{H}, \mathrm{CON}\left(\mathrm{CH}_{2} \mathrm{CH}_{3}\right)_{2}\right) ; 3.56\left(\mathrm{t}, 2 \mathrm{H}, \mathrm{CH}_{2} \mathrm{OH}\right) ; 4.68$ (t, $\left.2 \mathrm{H}, \mathrm{CH}_{2} \mathrm{~N}^{+}\right) ; 8.15(\mathrm{t}, \mathrm{IH}, \mathrm{CHCHCCO}) ; 8.57(\mathrm{~d}, \mathrm{IH}, \mathrm{CH} C H \mathrm{CCO}) ; 8.95\left(\mathrm{~d}, \mathrm{IH}, \mathrm{CH} C H \mathrm{~N}^{+}\right.$); $9.06\left(\mathrm{~s}, \mathrm{IH}, \mathrm{N}^{+} \mathrm{CHCCO}\right)$.

\section{p(CBA-ABOL/NicMe)}

$\mathrm{p}(\mathrm{CBA}-\mathrm{ABOL} / \mathrm{NicMe})$ was synthesized from $150 \mathrm{mg}$ of $\mathrm{p}\left(\mathrm{CBA}-\mathrm{ABOL}_{75} /\left(\mathrm{NH}_{2}\right)_{25}\right)$ (o.II mmol, I eq of primary amines) and $44 \mathrm{mg}$ (0.15 mmol, I.2 eq) of $N$-methylnicotinamide Zincke salt under the same conditions as described for $\mathrm{p}\left(\mathrm{CBA}-\mathrm{ABOL} / \mathrm{NicEt}_{2}\right)$, employing the Zincke salt of $N$-methylnicotinamide instead $N, N$-diethylnicotinamide. Yield: $56 \mathrm{mg}$ 
(33\%); ${ }^{\mathrm{H}} \mathrm{H}$ NMR ( $\left.\mathrm{D}_{2} \mathrm{O}\right) \delta(\mathrm{ppm})$ : I.58 (m, $2 \mathrm{H}, \boldsymbol{C H}_{2} \mathrm{CH}_{2} \mathrm{CH}_{2} \mathrm{OH}$ ); I.79 (m, $2 \mathrm{H}, \boldsymbol{C H}_{2} \mathrm{CH}_{2} \mathrm{OH}$ ); I. $88\left(\mathrm{~m}, 2 \mathrm{H}, \mathrm{CH}_{2} \mathrm{CH}_{2} \mathrm{CH}_{2} \mathrm{~N}^{+}\right) ; 2.12\left(\mathrm{~m}, 2 \mathrm{H}, \mathrm{CH}_{2} \mathrm{CH}_{2} \mathrm{~N}^{+}\right) ; 2.77(\mathrm{t}, 2 \mathrm{H}, \mathrm{NHCOCH}) ; 2.82$ (t, $\left.4 \mathrm{H}, \mathrm{CH}_{2} \mathrm{SSCH} \mathrm{CH}_{2}\right) ; 2.94\left(\mathrm{~s}, 3 \mathrm{H}, \mathrm{CONH} \mathrm{CH}_{3}\right) ; 3.22\left(\mathrm{t}, 2 \mathrm{H}, \mathrm{CH}_{2} \mathrm{CH}_{2} \mathrm{CH}_{2} \mathrm{NR}_{2}\right) ; 3.44(\mathrm{t}, 4 \mathrm{H}$, $\mathrm{CH}_{2} \mathrm{NRCH}$ ); 3.5I (t, $4 \mathrm{H}, \mathrm{NH} \mathrm{CH}_{2} \mathrm{CH}_{2} \mathrm{SSCH}_{2} \mathrm{CH}_{2} \mathrm{NH}$ ); $3.60\left(\mathrm{t}, 2 \mathrm{H}, \mathrm{CH}_{2} \mathrm{OH}\right) ; 4.7 \mathrm{I}(\mathrm{t}, 2 \mathrm{H}$, $\left.\mathrm{CH}_{2} \mathrm{~N}^{+}\right) ; 8.18(\mathrm{t}, \mathrm{IH}, \mathrm{CHCHCCO}) ; 8.84(\mathrm{~d}, \mathrm{IH}, \mathrm{CH} C H \mathrm{CCO}) ; 9.03\left(\mathrm{~d}, \mathrm{IH}, \mathrm{CHCHN} \mathrm{N}^{+}\right) ; 9.28$ (s, $\left.\mathrm{IH}, \mathrm{N}^{+} \mathrm{CHCCO}\right)$.

\section{p(CBA-ABOL/Nic)}

$\mathrm{p}(\mathrm{CBA}-\mathrm{ABOL} / \mathrm{Nic})$ was synthesized from $300 \mathrm{mg}$ of $\mathrm{p}\left(\mathrm{CBA}-\mathrm{ABOL}_{75} /\left(\mathrm{NH}_{2}\right)_{25}\right)(0.2 \mathrm{I}$ mmol, I eq of primary amines) and $84 \mathrm{mg}$ (0.3 $\mathrm{Imol}$, I.2 eq) of nicotinamide Zincke salt under the same conditions as described for $\mathrm{p}\left(\mathrm{CBA}-\mathrm{ABOL} / \mathrm{NicEt}_{2}\right)$, employing the Zincke salt of nicotinamide instead $\mathrm{N}, \mathrm{N}$-diethylnicotinamide. Yield: $\mathrm{I} 84 \mathrm{mg}(55 \%) ;{ }^{\mathrm{r}} \mathrm{H} \mathrm{NMR}$ $\left(\mathrm{D}_{2} \mathrm{O}\right) \delta(\mathrm{ppm}): \mathrm{I} .58\left(\mathrm{~m}, 2 \mathrm{H}, \boldsymbol{C H}_{2} \mathrm{CH}_{2} \mathrm{CH}_{2} \mathrm{OH}\right) ; \mathrm{I} .73\left(\mathrm{~m}, 2 \mathrm{H}, \boldsymbol{C H}_{2} \mathrm{CH}_{2} \mathrm{OH}\right) ; \mathrm{I} .87(\mathrm{~m}, 2 \mathrm{H}$, $\left.\mathrm{CH}_{2} \mathrm{CH}_{2} \mathrm{CH}_{2} \mathrm{~N}^{+}\right) ; 2.12\left(\mathrm{~m}, 2 \mathrm{H}, \mathrm{CH}_{2} \mathrm{CH}_{2} \mathrm{~N}^{+}\right) ; 2.76(\mathrm{t}, 2 \mathrm{H}, \mathrm{NHCOCH}) ; 2.8 \mathrm{I}(\mathrm{t}, 4 \mathrm{H}$, $\left.\mathrm{CH}_{2} \mathrm{SSCH}_{2}\right) ; 3.23\left(\mathrm{t}, 2 \mathrm{H}, \mathrm{CH}_{2} \mathrm{CH}_{2} \mathrm{CH}_{2} \mathrm{NR}_{2}\right) ; 3.44\left(\mathrm{t}, 4 \mathrm{H}, \mathrm{CH}_{2} \mathrm{NRCH}_{2}\right) ; 3.50(\mathrm{t}, 4 \mathrm{H}$, $\left.\mathrm{NH} \mathrm{CH}_{2} \mathrm{CH}_{2} \mathrm{SSCH}_{2} \mathrm{CH}_{2} \mathrm{NH}\right) ; 3.59\left(\mathrm{t}, 2 \mathrm{H}, \mathrm{CH}_{2} \mathrm{OH}\right) ; 4.74\left(\mathrm{t}, 2 \mathrm{H}, \mathrm{CH}_{2} \mathrm{~N}^{+}\right) ; 8.18(\mathrm{t}, \mathrm{IH}$,

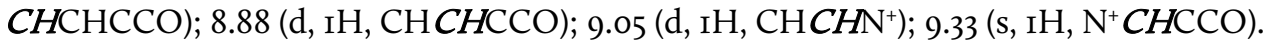

\section{p(CBA-ABOL/NicPh)}

$\mathrm{p}(\mathrm{CBA}-\mathrm{ABOL} / \mathrm{Nic} \mathrm{Ph})$ was synthesized from $\mathrm{I5}$ o mg of $\mathrm{p}\left(\mathrm{CBA}-\mathrm{ABOL}_{75} /\left(\mathrm{NH}_{2}\right)_{25}\right)(0.2 \mathrm{I}$ mmol, I eq of primary amines) and $52 \mathrm{mg}$ (0.3I mmol, I.2 eq) of $N$-phenylnicotinamide Zincke salt under the same conditions as described for $\mathrm{p}\left(\mathrm{CBA}-\mathrm{ABOL} / \mathrm{NicEt}_{2}\right)$, employing the Zincke salt of $N$-phenylnicotinamide instead $N, N$-diethylnicotinamide. Yield: $53 \mathrm{mg}$ (30\%); ' ${ }^{\mathrm{H}} \mathrm{NMR}\left(\mathrm{D}_{2} \mathrm{O}\right) \delta$ (ppm): I. 57 (m, $2 \mathrm{H}, \boldsymbol{C H}_{2} \mathrm{CH}_{2} \mathrm{CH}_{2} \mathrm{OH}$ ); I.77 (m, $2 \mathrm{H}, \boldsymbol{C H}_{2} \mathrm{CH}_{2} \mathrm{OH}$ ); I.9I (m, $\left.2 \mathrm{H}, \mathrm{CH}_{2} \mathrm{CH}_{2} \mathrm{CH}_{2} \mathrm{~N}^{+}\right) ; 2 . \mathrm{I} 6\left(\mathrm{~m}, 2 \mathrm{H}, \mathrm{CH}_{2} \mathrm{CH}_{2} \mathrm{~N}^{+}\right) ; 2.67$ (t, $\left.2 \mathrm{H}, \mathrm{NHCOCH}_{2}\right) ; 2.82(\mathrm{t}$, $\left.4 \mathrm{H}, \mathrm{CH}_{2} \mathrm{SSCH}_{2}\right) ; 3.2 \mathrm{I}\left(\mathrm{t}, 2 \mathrm{H}, \mathrm{CH}_{2} \mathrm{CH}_{2} \mathrm{CH}_{2} \mathrm{NR}_{2}\right) ; 3.44$ (t, $4 \mathrm{H}, \mathrm{CH}_{2} \mathrm{NRCH}$ ); $3.5 \mathrm{I}(\mathrm{t}, 4 \mathrm{H}$, $\left.\mathrm{NHCH} \mathrm{CH}_{2} \mathrm{SSCH}_{2} \mathrm{CH}_{2} \mathrm{NH}\right) ; 3.60\left(\mathrm{t}, 2 \mathrm{H}, \mathrm{CH}_{2} \mathrm{OH}\right) ; 4.74\left(\mathrm{t}, 2 \mathrm{H}, \mathrm{CH}_{2} \mathrm{~N}^{+}\right) ; 7.3 \mathrm{I}(\mathrm{t}, \mathrm{IH}$, $\mathrm{NHCCHCHCHCHCH}) ; \quad 7.47 \quad(\mathrm{t}, \quad 2 \mathrm{H}, \quad \mathrm{NHCCH} C H C H C H C H) ; \quad 7.58 \quad(\mathrm{~d}, \quad 2 \mathrm{H}$, $\mathrm{NHCCHCHCHCHCH}$ ); 8.22 (t, IH, CHCHCCO); 8.98 (d, IH, CHCHCCO); 9.07 (d, IH,

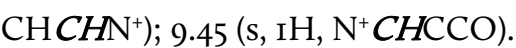

\subsubsection{Determination of the relative intercalation strength of the quaternary nicotinamide compounds}

$2 \mathrm{ml}$ of an ethidium bromide solution $(0.64 \mathrm{\mu g} / \mathrm{ml})$ in HSE buffer (2mM HEPES pH7.0, $8 \mathrm{mM} \mathrm{NaCl}$ and $50 \mu \mathrm{M}$ EDTA) was titrated with a concentrated plasmid DNA solution $(200 \mu \mathrm{g} / \mathrm{ml})$ in HSE buffer and the fluorescence of the solution was measured

172 - Chapter 9 
after every addition $\left(\lambda_{\mathrm{exc}}=510 \mathrm{~nm} ; \lambda_{\mathrm{em}}=595 \mathrm{~nm}\right)$ on a Varian Cary Eclipse fluorescence spectrophotometer. The saturation point of intercalated ethidium ions in the DNA base pairs was determined graphically as the DNA concentration where $90 \%$ of the available intercalation sites in DNA were occupied with intercalated ethidium ions in the DNA helix. A tangent line on the first data points was used to determine a linear relation based on 100\% occupied intercalation sites. Subsequently, 90\% occupation was found as the DNA concentration where the titration curve started to deviate more than Io\% from the tangent line. At the $90 \%$ occupation point, the ratio of the concentration of EtBr to the concentration of DNA basepairs was 0.18 and this ratio was finally used in the measurements of the intercalation strength of the model compounds. To determine the intercalation strength of the nicotinamide derivatives, DNA was incubated with the desired model compounds (molar ratio nicotinamide derivatives to DNA basepairs = IOoo:I) in HSE buffer with a final DNA concentration of $\mathrm{Io} \mu \mathrm{g} / \mathrm{ml}$ and incubated at room temperature. After one hour of incubation, $\mathrm{EtBr}$ was added resulting in an final $\mathrm{EtBr}$ concentration of $\mathrm{I} . \mathrm{I2} \mu \mathrm{g} / \mathrm{ml}$ and the fluorescence of intercalated ethidium ions was measured.

\subsubsection{Buffer capacity}

The buffer capacity was determined by an acid-base titration. All polymers were dissolved with a concentration of $\mathrm{I} .5 \mathrm{mM}$ of protonable nitrogens in $150 \mathrm{mM} \mathrm{NaCl}$. Io $\mathrm{ml}$ of these solutions were taken out and the $\mathrm{pH}$ was adjusted to 3.0 using $0.5 \mathrm{M} \mathrm{HCl}$. Subsequently, this solution was titrated with o.or $\mathrm{M} \mathrm{NaOH}$ to $\mathrm{pH}$ Io using an automated titrator (Metrohm 702 SM Titrino). As a reference, the same procedure was applied to branched PEI $(25 \mathrm{~kg} / \mathrm{mol})$ and $150 \mathrm{mM} \mathrm{NaCl}$ solutions. The buffer capacity is defined as the percentage of nitrogen becoming deprotonated from $\mathrm{pH}$ 5.I to $\mathrm{pH} 7.4$ and can be calculated from (I):

$$
\text { Buffer capacity }=\frac{C_{\mathrm{NaOH}}\left(\Delta V_{\mathrm{p}}-\Delta V_{\mathrm{NaCl}}\right)}{n} \times 100 \%
$$

Where $\Delta V_{p}$ and $\Delta V_{\mathrm{NaCl}}$ are the volumes of $\mathrm{NaOH}$ solution added between $\mathrm{pH}$ 5.I and 7.4 to the polymer solution and a blank $\mathrm{NaCl}$ solution, respectively, and $n$ is total amount of protonable nitrogens present in the polymer solution.

\subsubsection{Polyplex preparation}

Polyplexes at different polymer/nucleotide mass ratios were prepared in HEPES buffered glucose (HBG: $20 \mathrm{mM}$ HEPES, $\mathrm{pH}$ 7.4, $5 \mathrm{wt} \%$ glucose). The polymer solution 
was added to the nucleotide solution in a volume ratio of $4 / \mathrm{I}$, followed by $5 \mathrm{~s}$ vortexing and $30 \mathrm{~min}$ incubation at room temperature.

\subsubsection{Polyplex properties}

Polyplexes containing $6.25 \mu \mathrm{g} / \mathrm{ml}$ siRNA or $10 \mu \mathrm{g} / \mathrm{ml} \mathrm{pDNA}$ were prepared at five different polymer/nucleotide mass ratios (3/I, 6/I, I2/I, 24/I and 48/I) as described above. The hydrodynamic diameter and the $\zeta$-potential were measured by dynamic light scattering on a Zetasizer Nano ZS (Malvern Instruments) at $25^{\circ} \mathrm{C}$.

\subsubsection{In vitro gene silencing}

Knockdown efficiency was determined by silencing luciferase expression in $\mathrm{NCl}-$ Hı299 cells, stably expressing firefly luciferase. Knockdown and cell viability were evaluated in two parallel sessions, using anti-luciferase and non-coding siRNA, respectively. Cells were seeded in 96 well plates with a density of 8000 cells per well. After $24 \mathrm{~h}$ incubation at $37^{\circ} \mathrm{C}$ in a humidified atmosphere containing $5 \% \mathrm{CO}_{2}$, medium was replaced with $100 \mu$ fresh medium without FBS. Polyplexes containing $6.25 \mu \mathrm{g} / \mathrm{ml}$ siRNA were prepared at five different polymer/siRNA mass ratios (3/I, 6/I, I2/I, 24/I and $48 / \mathrm{I}$ ) as described above. Lipofectamine 2000 was used as a reference and complexes were prepared according to the manufacturer's protocol. Polyplexes ( $20 \mu \mathrm{l}$ per well) were added to the cells in quinto after I hour incubation with fresh medium, resulting in a final siRNA concentration of $66 \mathrm{nM}$. After 2 hours of transfection, polyplex medium was replaced by complete culture medium and the cells were incubated for another 48 hours. Cells were lysed in a freeze/thaw cycle and $50 \mu \mathrm{l}$ of the cell lysate was mixed with $50 \mu \mathrm{l}$ luciferase assay reagent containing the substrate luciferin. After too - 220 seconds (in this timeframe the emitted light is constant - data not shown) the luciferase activity was determined by measuring the luminescence at $25^{\circ} \mathrm{C}$ for 4 seconds on a PerkinElmer I420 Victor ${ }^{3}$ plate reader. Luciferase activity of untreated cells was defined as $100 \%$ expression.

\subsubsection{Uptake of siRNA complexes}

The uptake of siRNA complexes was studied by flow cytometry using NCl-Hi299 cells. Cells were seeded in 24 well plates with a density of 48000 cells per well. After $24 \mathrm{~h}$ incubation at $37^{\circ} \mathrm{C}$ in a humidified atmosphere containing $5 \% \mathrm{CO}_{2}$, medium was replaced with $600 \mu \mathrm{l}$ fresh medium without FBS. Polyplexes containing $6.25 \mu \mathrm{g} / \mathrm{ml}$ siRNA were prepared at polymer/siRNA mass ratio 24/I as described above using FITC labeled siRNA. Lipofectamine 2000 was used as a reference and complexes were

$174 \cdot$ Chapter 9 
prepared according to the manufacturer's protocol. Polyplexes (I20 $\mu \mathrm{l}$ per well) were added to the cells in duplo after I hour incubation with fresh medium, resulting in a final siRNA concentration of $66 \mathrm{nM}$. After 2 hours of transfection, the cells were washed with PBS, trypsinized and suspended in PBS containing Io \% (v/v) FBS. The mean fluorescence intensity per cell was determined on a Becton Dickenson FACSCalibur flow cytometer.

\subsubsection{In vitro gene expression}

Transfection and cell viability experiments were performed with COS-7 cells or $\mathrm{NCl}-\mathrm{H} 1299$ cells using pCMV-GFP DNA as a reporter gene. Gene expression (green fluorescent protein) and cell viability (XTT) were evaluated in two separate parallel sessions. Cells were seeded in 96 well plates with a density of Ioooo (COS-7) or 8000 (Hi299) cells per well. After $24 \mathrm{~h}$ incubation at $37^{\circ} \mathrm{C}$ in a humidified atmosphere containing $5 \% \mathrm{CO}_{2}$, medium was replaced with $100 \mu$ l fresh medium without FBS. Polyplexes containing Io $\mu \mathrm{g} / \mathrm{ml} \mathrm{pDNA}$ were prepared at five different polymer/siRNA mass ratios (3/I, 6/I, I2/I, 24/I and 48/I) as described above. Linear PEI (Exgen 500, N/P = $5 / \mathrm{I}$ ) was used as a reference. Optimized transfection conditions were used for both cell lines and polyplexes (Ioo $\mu \mathrm{l}$ (COS-7) or $50 \mu \mathrm{l}$ (Hi299) per well) were added to the cells in quinto after I hour incubation with fresh medium. After I hour (COS-7) or 2 hours (Hi299) of transfection, polyplex medium was replaced by complete culture medium and the cells were incubated for another 48 hours. Transfection efficiency was determined by measuring the GFP expression on a Magellan Tecan Safire Il 96 wells plate reader. Excitation was at $480 \mathrm{~nm}$ and optimal emission was determined at $503 \mathrm{~nm}$. Cell viability was assessed by an XTT proliferation assay in which untreated cells were defined as Ioo\% viable. $48 \mathrm{~h}$ after transfection the cells were washed and incubated for I hour in colorless culture medium supplemented with $0.5 \mathrm{mM}$ XTT and $25 \mu \mathrm{M}$ PMS. Absorption of the orange colored formazan salt, formed by metabolic active cells, was determined on a Magellan Tecan Safire Il 96 wells plate reader at $450 \mathrm{~nm}$ in colorless culture medium.

\subsection{Results and discussion}

\subsubsection{Synthesis and characterization of the copolymers}

Four bioreducible poly(amido amine) (SS-PAA) copolymers were synthesized having different quaternary nicotinamide groups in their side chains. All these polymers 
were synthesized from the same parent polymer to guarantee similar molecular weight and morphology, allowing for a good comparison between the different polymers. The synthesis of this polymer was already described in chapter 8 and proceeded by Michael addition polymerization with a mixture of $N, N^{\prime}$-cystaminebisacrylamide (CBA), Iamino-4-butanol (ABOL) and $N$-Boc-I,4-diaminobutane (NHBoc), yielding a polymer with hydroxybutyl and Boc-protected aminobutyl sidegroups. In the second step the Boc-protecting group was removed with trifluoroacetic acid, to obtain pending primary amine side groups. It was decided to use the polymer with $75 \mathrm{~mol}$ percent $\mathrm{ABOL}$ as side groups and $25 \mathrm{~mol}$ percent nicotinamide derivatives in this study, since the previous study has shown that the $\mathrm{p}\left(\mathrm{CBA}-\mathrm{ABOL}_{75} / \mathrm{Nic}_{25}\right)$ polymer formed small and positively charged polyplexes at low polymer excesses and showed good gene expression in pDNA transfections with negligible cytotoxicity. Therefore, the pending primary amines of the $\mathrm{p}\left(\mathrm{CBA}-\mathrm{ABOL}_{75} /\left(\mathrm{NH}_{2}\right)_{25}\right)$ polymer were functionalized with four different quaternary nicotinamide derivatives: $\quad N, N$-diethylnicotinamide, $\quad N$-methylnicotinamide, nicotinamide and $\mathrm{N}, \mathrm{N}$-phenylnicotinamide as is displayed in Scheme 9.I. The grafting was performed via the Zincke reaction following the same procedure as described in chapter 8 and Scheme 8.I. All the functionalized polymers were obtained as a yellow brittle material in yields of $30-55 \%$. The obtained $\mathrm{ABOL} /$ nicotinamide molar percent ratios were determined from the ${ }^{\mathrm{I}} \mathrm{H}$ NMR spectra at $75 / 25$ (data not shown), which is in good accordance with the parent polymer. Also the molecular weights of all the polymers were supposed to be similar, since all polymers were synthesized from the same parent polymer.

\subsubsection{Determination of the relative intercalation strength of the quaternary nicotinamide compounds}

Before doing the complexation studies of the polymers with siRNA and pDNA, first the complexation behavior of low molecular weight nicotinamide model compounds were investigated for their relative capacity to intercalate with pDNA. The relative intercalation strength was studied in an ethidium bromide (EtBr) competition assay of pDNA with $N$-butylated quaternary nicotinamide derivatives (Scheme 9.2). Quaternary pyridine and n-butyl amine, which is protonated at physiological $\mathrm{pH}$, were included as reference materials.

To be able to measure any competition effect, an $\mathrm{EtBr}$ concentration is required where $\mathrm{EtBr}$ intercalates in nearly every available site in DNA. This point was defined as the EtBr/DNA ratio where $90 \%$ of the available intercalation sites is occupied by ethidium ions and was determined from the fluorescence measured by titration of a solution of EtBr with DNA.

$176 \cdot$ Chapter 9 


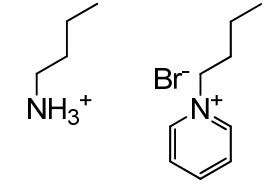

$\mathrm{BuNH}_{2}$

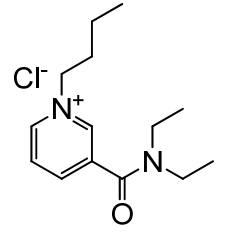

BuNicEt $_{2}$

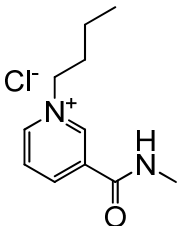

BuNicMe

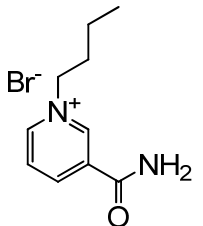

BuNic

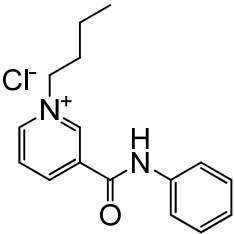

BuNicPh

Scheme 9.2: $\mathrm{N}$-butyl quaternized nicotinamide derivatives as models for the determination of the relative intercalation strength.

The intercalation strength relative to EtBr was determined from the fluorescence of EtBr/DNA solutions after incubation with the model compound and is shown in Figure 9.I. Butylamine, which is fully protonated at the used $\mathrm{pH}$, served as a control and it is shown that this compound does not compete with ethidium for DNA. Addition of potassium chloride and potassium bromide have only minor effects and the small reduction in fluorescence is probably caused by the change in ionic strength of the solution. Figure 9.I clearly demonstrates that the fluorescence is significantly lower when DNA was pre-incubated with the quaternary compounds and that there is quite some difference in intercalation strength among the different model intercalators. As discussed earlier in chapter 8 , intercalating species should be planar to fit in between the basepairs and the presence of positive charge, a $\pi$-electron system to interact with the aromatic basepairs and the ability to form and accept hydrogen bonds will further reinforce the intercalation strength. These four contributing parameters are clearly reflected in the measured intercalation strengths. Only the aromatic compounds show intercalation, where BuPyr, that does not have any ability to form or accept hydrogen bonds even did not show higher reduction in fluorescence than an equal amount of $\mathrm{KBr}$, indicating that it is only very weakly or not intercalating. In the nicotinamide series, BuNicEt $_{2}$ that can accept only two hydrogen bonds on the carbonyl oxygen atom is the weakest intercalator. BuNicMe, that can accept two hydrogen bonds and donate one hydrogen bond, shows an increased intercalation strength compared to $\mathrm{BuNicEt}_{2}$. BuNic is the second strongest intercalator and can donate two and accept two hydrogen

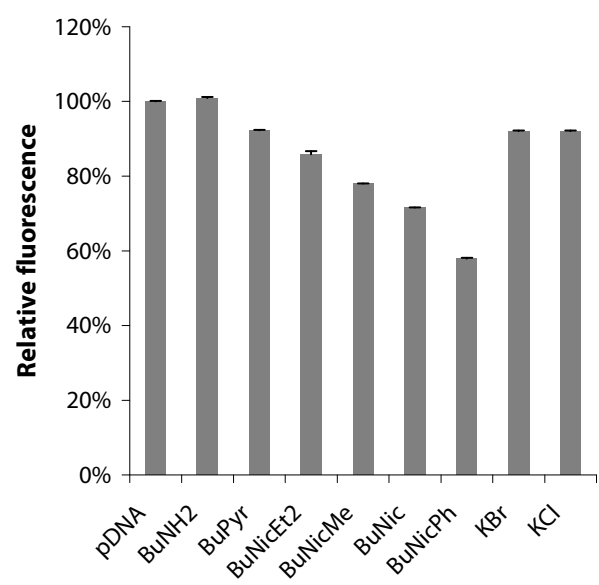

Figure 9.1: The relative fluorescence of ethidium/DNA intercalation of DNA pre-incubated with butyl quaternized model compounds (b). Butylamine $\left(\mathrm{BuNH}_{2}\right)$, potassium bromide $(\mathrm{KBr})$ and potassium chloride $(\mathrm{KCl})$ were used as negative controls. 
bonds. The strongest intercalator, $\mathrm{BuNicPh}$, can accept two hydrogen bonds and donate one hydrogen bond, but possesses an extra $\pi$-electron system, that can strengthen the $\pi$-interaction with the basepairs of DNA.

Although it is clearly demonstrated by the model compounds are intercalating, the intercalation is not very strong considering the high excess in concentration of the model compounds that was applied relative to $\mathrm{EtBr}$ (more than 5000 times). However, it should be realized that in case of the nicotinamide functionalized polymers, there exists a relatively high local concentration of intercalating sidegroups after complexation of DNA and polymer and the intercalation equilibrium undergoes a cooperative effect. For bis-intercalators the binding to DNA is already increased dramatically [4] and Kuruvilla et al. observed even a 36-fold increase in DNA binding for bisacridines [5]. Therefore, it can be expected that the binding strength of our intercalating polymers will also be a few orders of magnitude higher than those of the studied model compounds. Moreover, it is not desired to have very strong intercalation binding of every single side chain to DNA, since once arrived in the cytosol the degraded polymer fragments should also be able to release from the nucleic acid to allow further activity of the nucleic acid in the gene expression process. In addition, very strong intercalators may even turn out to be carcinogenic [6].

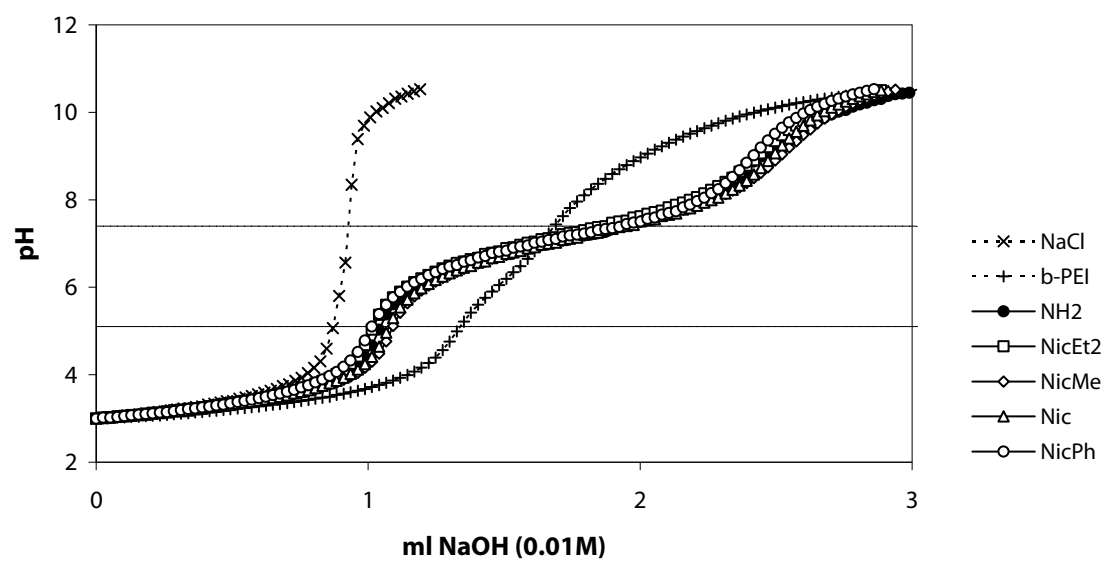

Figure 9.2: Titration curves of $\mathrm{p}(\mathrm{CBA}-\mathrm{ABOL} / \mathrm{Nic})$ obtained by titration of $0.015 \mathrm{mmol}$ protonable nitrogens (polymer) with $0.01 \mathrm{M}$ sodium hydroxide solution. b-PEI $(25 \mathrm{~kg} / \mathrm{mol})$ was included as a reference.

\subsubsection{Buffer capacity of the polymers}

In order obtain an indication of their endosomal escape capacity, the buffering behavior of the polymers was studied by titration of a standard polymer solution

178 - Chapter 9 
between $\mathrm{pH}$ 5.I and 7.4 (see chapter 8). All polymers show good buffer capacities in this range, as is indicated by flattening of the titration curve in Figure 9.2, and the derived values are given in Table 9.I. Based on these data, it is therefore not expected that limited endosomal escape will be a dominant factor in the performance of polyplexes from these polymers.

Table 9.1: Buffer capacity of all polymers determined by acid/base titration.

\begin{tabular}{ll}
\hline Polymer & Buffer capacity \\
\hline b-PEl & $15 \%$ \\
$\mathrm{p}\left(\mathrm{CBA}-\mathrm{ABOL} / \mathrm{NH}_{2}\right)$ & $53 \%$ \\
$\mathrm{p}\left(\mathrm{CBA}-\mathrm{ABOL} / \mathrm{NicEt}_{2}\right)$ & $52 \%$ \\
$\mathrm{p}(\mathrm{CBA}-\mathrm{ABOL} / \mathrm{NicMe})$ & $53 \%$ \\
$\mathrm{p}(\mathrm{CBA}-\mathrm{ABOL} / \mathrm{Nic})$ & $54 \%$ \\
$\mathrm{p}(\mathrm{CBA}-\mathrm{ABOL} / \mathrm{NicPh})$ & $57 \%$ \\
\hline
\end{tabular}

\subsubsection{Particle properties}

All the synthesized copolymers were used to form polyplexes with both siRNA and pDNA and the hydrodynamic diameters and surface potentials were determined by dynamic light scattering (DLS). Polyplexes were prepared in a non-ionic buffer to eliminate interference with other species in solution and allow the direct evaluation of structural effects on polymer / nucleotide complexation.

The particle size and $\zeta$-potential of the siRNA polyplexes of the different polymers are shown in Figure 9.3a. At the low 3/1 polymer/siRNA weight ratio all polymers form large aggregates with low or negative surface potentials, but at the 6/I polymer/siRNA weight ratio, there is a remarkable difference in particle size. At that ratio the polymers containing the strongest intercalating nicotinamides ( $\mathrm{Nic}$ and $\mathrm{NicPh}$ ) form the smallest particles. At higher polymer/siRNA ratios, the differences are less pronounced, indicating that the gained extra siRNA/polymer interaction from intercalation is now overruled by the presence of excess of cationic polymer in the solution. At the I2/I polymer/siRNA weight ratio and higher all polyplex sizes are generally around $200 \mathrm{~nm}$ or lower. The $\zeta$-potentials are positive for all polyplexes at measured polymer siRNA/weight ratios from 6/I and higher, indicating that the siRNA is in the interior of the complexes. All polyplexes smaller than $200 \mathrm{~nm}$ have $\zeta$-potentials between 20 and 33 $\mathrm{mV}$. It is remarkable that the $\zeta$-potentials of the stronger intercalating $\mathrm{Nic}$ and $\mathrm{NicPh}$ polymers at polymer/siRNA weight ratio I2/I and higher are generally higher than those of the non-intercalating $\mathrm{NH}_{2}$ and less intercalating $\mathrm{NicEt}_{2}$ and NicMe polymers. This may be caused by a more dense packing and the assembling of a higher amount of positively charged polymer on the complexes of the stronger intercalating polymers, resulting in a denser and higher net charge in the polyplexes. 
The general trends in complexation of pDNA with these polymers are generally the same as in complexing siRNA, although there are small differences (Figure 9.3b). Also here the particle size is decreasing with increasing amount of polymer and becomes below $200 \mathrm{~nm}$ at $\mathrm{I} 2 / \mathrm{I}$ polymer/pDNA weight ratio and higher. The smallest polyplexes were however not only formed from the best intercalating nicotinamides (Nic and $\mathrm{NicPh}$ ), but also from the polymer with the protonated $\mathrm{BuNH}_{2}$ sidegroups. The electrostatic interaction of the non-polarizable cationic charge on this amine with the phosphate anions of pDNA is considered to be stronger than the polarizable and dissipated cationic charge on pyridinium ions, where the cationic charge is partially distributed over the aromatic ring. Positively charged polyplexes ( $\zeta$-potentials between 20 and $35 \mathrm{mV}$ ) were formed from a polymer to pDNA weight excess of I2 and higher for all nicotinamide-containing polyplexes and there is no significant difference between the different polymers as was observed with siRNA.
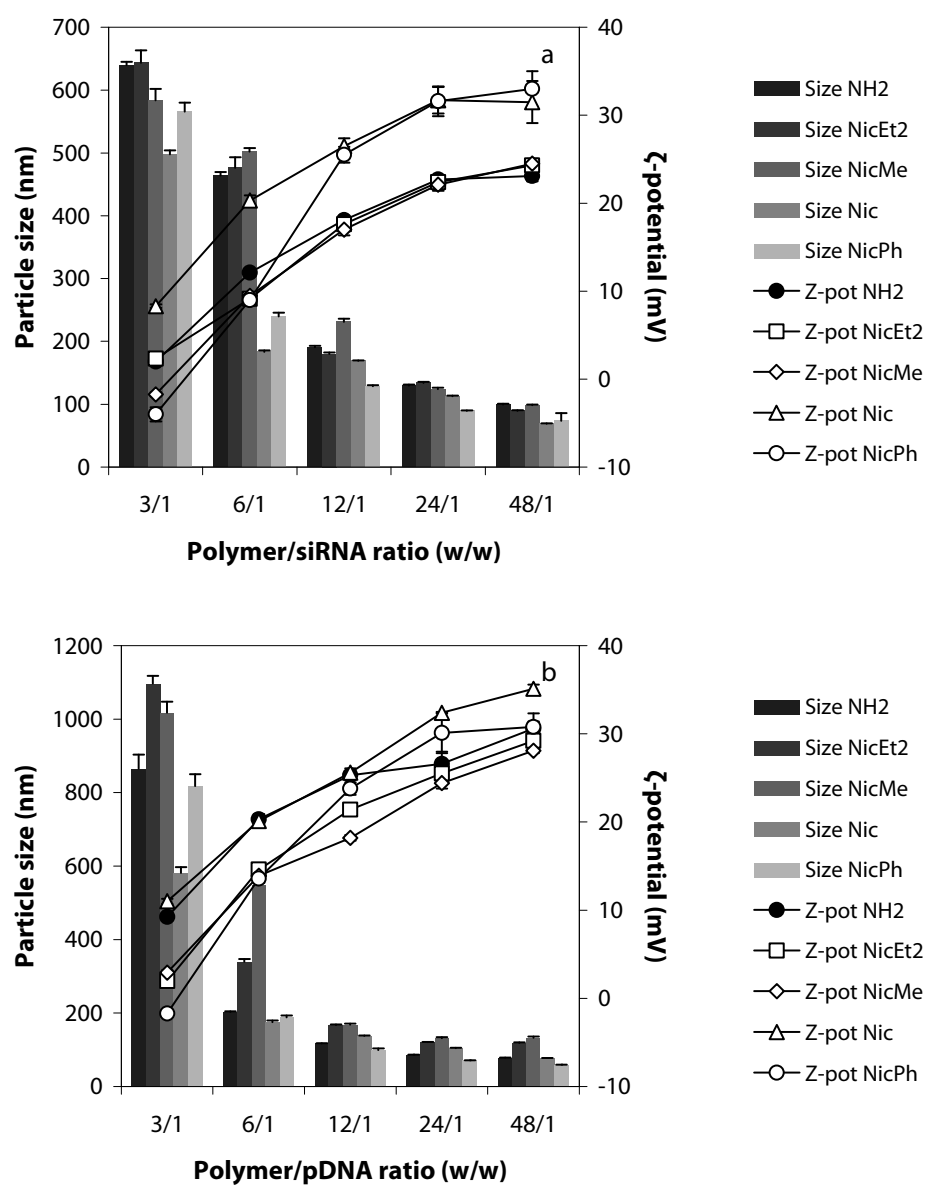

Figure 9.3: Particle size (bars) and $\zeta$-potential (lines) of polyplexes formed at several polymer/nucleotide weight ratios with siRNA (a) or PDNA (b).

$180 \cdot$ Chapter 9 


\subsubsection{In vitro gene silencing}

Hi299 cells were used to evaluate the silencing potential of the polymers and luciferase, which was stably expressed by these cells, was used as target for silencing. Polyplexes in five different polymer/siRNA weight ratios were prepared from antiluciferase siRNA and a non-coding control siRNA and were applied to the cells. Luciferase expressions two days after transfection were determined from emitted light in the enzyme-substrate reaction in the cell lysates mixed with luciferin and are plotted in Figure 9.4.
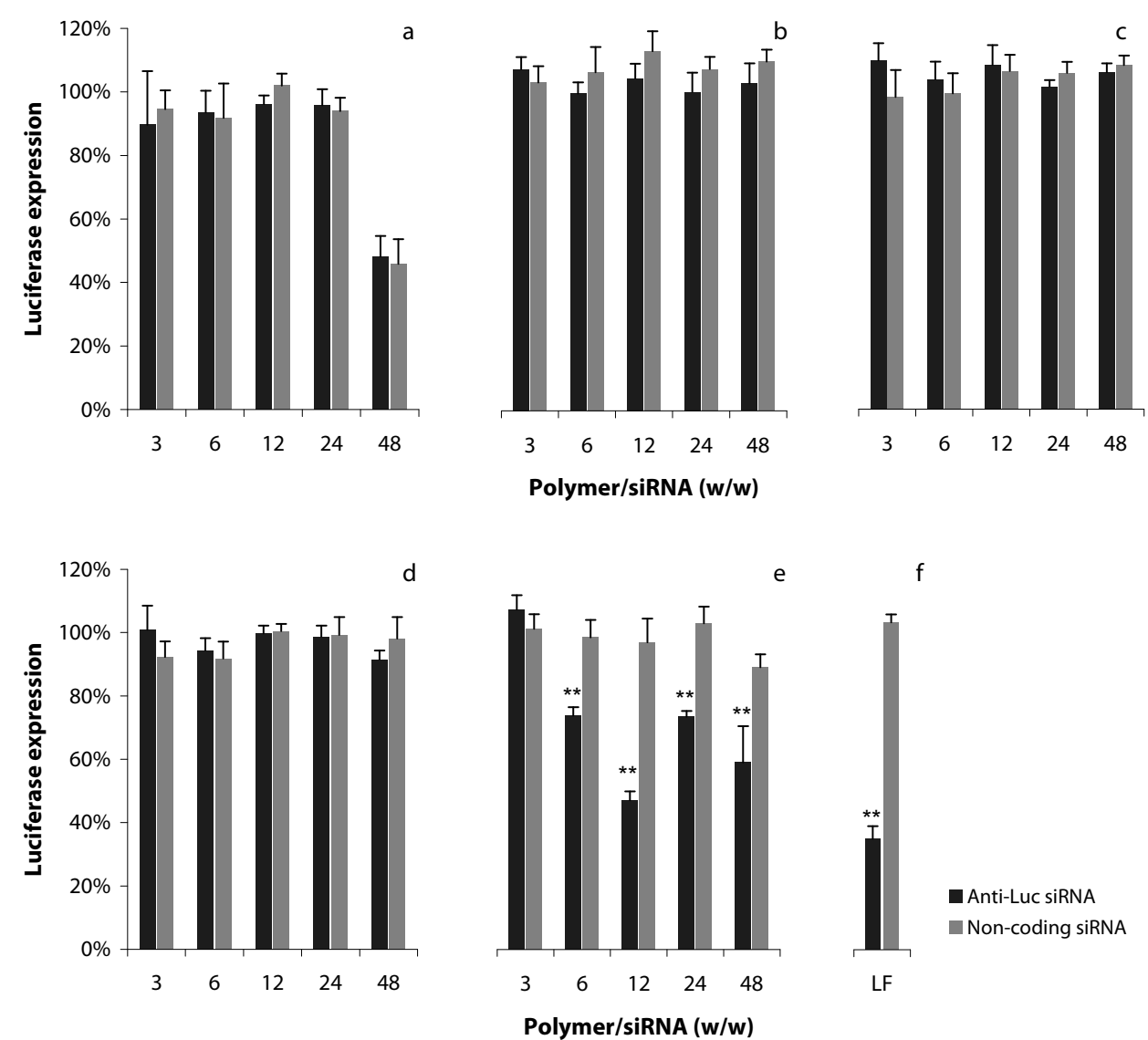

Figure 9.4: Luciferase expression of H1299 Fluct cells 48 hours after transfection with anti-luciferase siRNA (black) and non-coding control siRNA (grey) with the polymers containing different nicotinamide derivatives: $\mathrm{NH}_{2}(\mathrm{a}), \mathrm{NicEt}_{2}$ (b), NicMe (c), Nic (d) and NicPh (e). Lipofectamine 2000 (LF) was used as reference transfection agent $(f)$. Each bar value represents the mean $\pm S D$ of $n=4$ or 5 . For statistical analysis of differences between anti-luciferase and non-coding siRNA an unpaired Student's t-test was used $\left({ }^{*} \mathrm{p}<0.05 ;{ }^{* *} \mathrm{p}<0.01\right)$. 
Figure 9.4a-e show that only polyplexes of NicPh (Figure 9.4e) successfully silence luciferase. The highest gene silencing (50\% remaining luciferase expression) for this polymer was obtained with polyplexes prepared at a polymer/siRNA weight ratio of I2/I. It is not exactly clear why the highest silencing was found at the I2/I ratio, but it is supposed that at higher polymer concentrations intercalating $\mathrm{NicPh}$ from degraded polymer fragments inhibit uptake in the dicer and the RISC complex, resulting in a decreased gene silencing. Because of the unexpected outcome, the complete experiment was repeated with similar results (data not shown). The polymer with the butylamine sidegroup $\left(\mathrm{NH}_{2}\right.$, Figure 9.4a) does not show any gene silencing, and even becomes toxic at the highest concentration used. The other nicotinamide-containing polymers do not show gene silencing ( $\mathrm{NiCEt}_{2}$, NicMe and Nic, respectively Figure $9.4 \mathrm{~b}, \mathrm{c}$ and d), but are non-toxic at all the used concentrations, which illustrates an important advantage of the use of quaternized nicotinamides for binding nucleotides over the use of primary amines for this purpose.
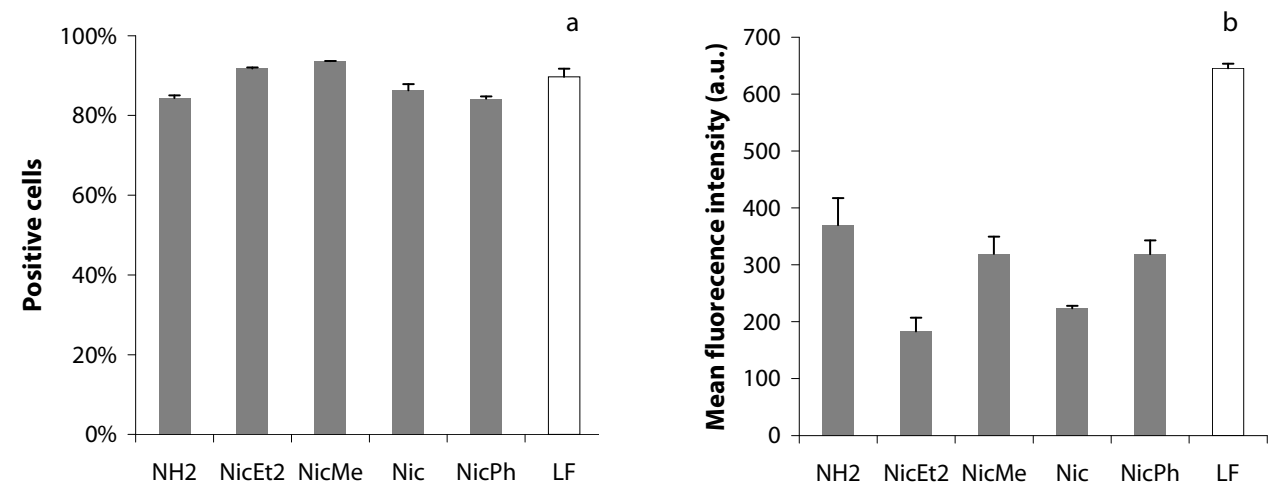

Figure 9.5: Uptake of fluorescein labeled siRNA complexed by the different nicotinamide-containing copolymers in H1299 cells: positive gated cells (a) and the mean fluorescence intensity per cell (b). Lipofectamine 2000 (LF) was used as reference transfection agent.

It is difficult to explain that there was only gene silencing when the strongest intercalating polymer ( $\mathrm{NicPh}$ ) was used. Uptake studies by flowcytometry, where these HI299 cells were transfected with polyplexes containing fluorescein labeled siRNA in a polymer siRNA weight ratio of 24/I, show that $80-100 \%$ of the cells was fluorescein positive for all the used polymers (Figure 9.5a), indicating successful cellular uptake. The mean fluorescence intensity differs between 200 and 400 arbitrary units, but does not show a relation to the intercalation capacity (Figure 9.5b). It is known that fluorescence is quenched inside a polyplex [7] and in chapter 8 it was found that quaternized nicotinamide significantly quenches the fluorescence of fluorescein. Also the

182 - Chapter 9 
quaternary nicotinamide derivatives quench fluorescein and it was found that the strongest intercalator $\mathrm{NicPh}$ induces the highest quenching (data not shown). Therefore, it may be possible that the intracellular siRNA concentration after transfection with $\mathrm{NicPh}$ is higher than when transfected with one of the other polymers, but that this is not observed because of the better quenching by the $\mathrm{NicPh}$ moieties in the polymer or in the degraded polymer fragments. A possible higher cellular uptake could be rationalized based on the more lipophilic character of $\mathrm{NicPh}$, as a result of the hydrophobic phenyl group, resulting in a better membrane interaction. It should, however, be noted that such explanation is only speculative and further experiments are required to obtain a better insight in the details of the uptake and silencing process.

\subsubsection{In vitro gene expression}

Previously, we discovered that quaternary nicotinamide-containing polymers are promising candidates as pDNA carriers [I]. In chapter 8 we showed that polyplexes from SS-PAAs with quaternary nicotinamide side chains in combination with hydroxylbutyl side chains $(\mathrm{ABOL})$ induce excellent gene expression, fivefold more efficient than linear PEI. In this chapter we evaluated the copolymers containing the nicotinamide derivatives for GFP expression in two different cell lines: COS-7 and Hi299. Also cell viabilities after polyplex treatment were assessed by a cell proliferation assay, based on XTT. The GFP expression induced by the different polyplexes was determined two days after incubation, and was compared to that caused by the use of linear PEI (Exgen 500) and is given together with cell viability in Figure 9.6a for COS-7 cells and in Figure 9.6b for Hi299 cells. At the relatively low polymer/pDNA weight ratio I2/I, the strongest intercalating polymers ( $\mathrm{Nic}$ and $\mathrm{NicPh}$ ) show already high GFP expression in COS-7 cells up to four times more efficient than linear PEI. At higher polymer/pDNA ratios, the gene expression of Nic increases even further to five times linear PEI. The gene expression of $\mathrm{NicPh}$ however dramatically decreases as a result of the increased cytotoxicity of this polymer as is indicated by a decrease in cell viability. The nonintercalating polymer with the primary amine sidegroups $\left(\mathrm{NH}_{2}\right)$ also gives gene expression, but with a maximum of three times linear PEI at the 24/I polymer/pDNA weight ratio. At a higher polymer concentration (48/I ratio), this polymer also becomes cytotoxic with a cell viability less than $50 \%$. The weaker intercalating polymers $\mathrm{NicEt}_{2}$ and NicMe show less gene expression than the stronger intercalating polymers Nic and $\mathrm{NicPh}$ at lower polymer/pDNA ratios, but perform comparable to Nic at 24/I ratio. This illustrates again that the added value of intercalation is most beneficial at lower polymer concentrations. It is supposed that at higher polymer concentrations the electrostatic interactions between the cationic charges in the rest of the polymer and the negative 
charges of the phosphate groups in pDNA overrule the intercalation effect in the formation of polyplexes.
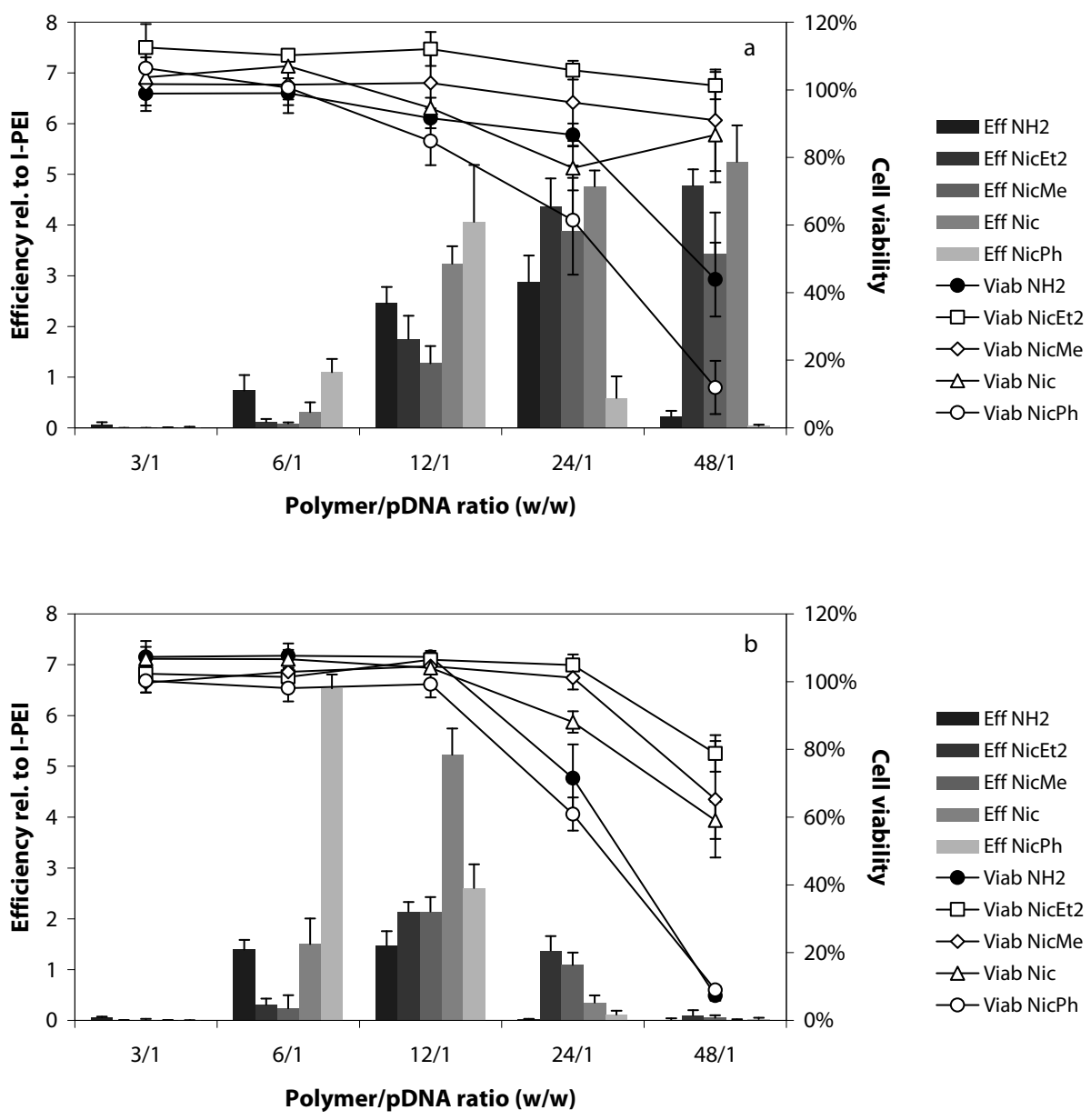

Figure 9.6: Transfection efficiencies (GFP expression, bars) and cell viabilities (lines) after polyplex incubation and 48 hours after transfection relative to I-PEI (Exgen 500) with the polymers containing different nicotinamide derivatives in COS-7 cells (a) and in $\mathrm{H} 1299$ cells (b). Cell viability of Exgen 500 treated cells showed a viability of $64 \pm 4 \%$ and $82 \pm 4 \%$ in COS-7 cells and H1299 cells, respectively. Each data point represents the mean $\pm S D$ of $n=4$ or 5 .

GFP expression was also studied in Hi299 cells, the same cell line as was used for gene silencing experiments. The results are in agreement with the transfection in COS7 cells, but the highest gene expression was found at lower polymer/pDNA weight ratio. Maximum gene expressions are achieved at a polymer/pDNA ratio of I2/I for Nic and 6/I for NicPh and are more than five and six times as efficient as linear PEI, respectively.

$184 \cdot$ Chapter 9 
The polymers become toxic in this cell line at higher ratios, especially $\mathrm{NicPh}$, which has a cell viability of less than I0\% at 48/I ratio. This is lower than observed in the gene silencing experiments in the same cell line and is the result of the higher polymer concentrations that are required in the pDNA tranfection protocol. $\mathrm{NicEt}_{2}$ and $\mathrm{NicMe}$ show a maximum in gene expression at I2/I polymer/pDNA ratio, which is $2-3$ times that of linear PEI and these polymers become slightly toxic at 48/I ratio, with cell viabilities between 60 and $80 \%$. The non-intercalating $\mathrm{NH}_{2}$ does not exceed an efficiency of two times linear PEI and appeared to be highly toxic, starting at a polymer/pDNA ratio of 24/I. This result again emphasizes the benefits of the use of quaternary nicotinamides over primary amines: similar or increased gene expressions are obtained with comparable polyplexes, but lacking a severe cytotoxic character. In addition, all the nicotinamide-containing polymers turned out to be non-hemolytic up to I $\mathrm{mg} / \mathrm{ml}$, where the $\mathrm{NH}_{2}$ polymer was slightly hemolytic (data not shown). Lastly, the polymers containing $\mathrm{Nic}$ and $\mathrm{NicPh}$ show gene expressions comparable to or higher than $\mathrm{p}(\mathrm{CBA}-\mathrm{ABOL})$, which is currently our most successful carrier for pDNA ([8], Chapter 3). These high gene expressions are already obtained at polymer concentrations that are four to eight times lower than required with $\mathrm{p}(\mathrm{CBA}-\mathrm{ABOL})$, making these polymers a very attractive alternative for pDNA delivery.

\subsection{Conclusions}

Four reducible poly(amido amine)s with $75 \%$ hydroxybutyl and $25 \%$ quaternary nicotinamide derivatives in their side chains were synthesized. The presence of these quaternary nicotinamide moieties resulted in improved properties to form stable polyplexes with siRNA and pDNA. It was found that the intercalating capacity of the quaternary nicotinamides is reduced by $\mathrm{N}$-alkylation of the amide functionality and is increased by $N$-phenylation of the amide functionality. Especially at low polymer/nucleotide weight ratios, strong intercalating side groups were found to contribute significantly in the formation of small and cationic polyplexes. At higher amounts of polymer, electrostatic interactions between the polymer and the nucleotide overruled the intercalative interactions. Gene silencing was only observed with polyplexes of polymers having the strongest intercalating sidegroup (NicPh). In pDNA transfections (GFP expression), the ability to intercalate turned out to be highly beneficial at low polymer/pDNA weight ratios. Both in COS-7 as well as in Hi299 cells this resulted in five to sixfold higher GFP expressions than those obtained with linear PEI, which is currently the standard in pDNA transfections. Such high level of gene expression is comparable to our existing $\mathrm{p}(\mathrm{CBA}-\mathrm{ABOL})$ transfection system, but with these quaternary nicotinamide-functionalized polymers this can be achieved with fourfold and eightfold lower polymer doses (COS-7 and Hi299 cells, respectively), 
without the occurrence of any cytotoxicity. Furthermore, it was found out that polymers with the quaternized nicotinamides are generally less toxic than a similar polymer with (protonated) primary amines, emphasizing that the introduction of quaternized nicotinamide groups is preferred over primary amino groups to achieve extra nucleotide binding capacity.

\subsection{Acknowledgement}

Thanks to Jan Hendriks for exploring the different nicotinamide derivatives.

\subsection{References}

I. $\quad$ Mateos-Timoneda, M.A., et al., Poly(amido amine)s as Gene Delivery Vectors: Effects of Quaternary Nicotinamide Moieties in the Side Chains.

ChemMedChem, 2007. 3: p. 478-486.

2. Steinhardt, S.E., J.S. Silverston, and C.D. Vanderwal, Stereocontrolled synthesis of $Z$-dienes via an unexpected pericyclic cascade rearrangement of 5-amino2,4-pentadienals. Journal of the American Chemical Society, 2008. 130(24): p. 7560-7561.

3. Lettre, H., W. Haede, and E. Ruhbaum, Zur Darstellung Von Derivaten Des Nicotinsaureamids. Annalen Der Chemie-Justus Liebig, I953. 579(2): p. I23-I32.

4. Ihmels, H. and D. Otto, Intercalation of organic dye molecules into doublestranded DNA general principles and recent developments, in Supermolecular Dye Chemistry. 2005. p. I6I-204.

5. Kuruvilla, E., J. Joseph, and D. Ramaiah, Novel bifunctional acridine-acridinium conjugates: Synthesis and study of their chromophore-selective electrontransfer and DNA-binding properties. Journal of Physical Chemistry B, 2005. I09(46): p. 21997-22002.

6. Ferguson, L.R. and W.A. Denny, Genotoxicity of non-covalent interactions: DNA intercalators. Mutation Research-Fundamental and Molecular Mechanisms of Mutagenesis, 2007. 623(I-2): p. I4-23.

7. Vader, P., et al., A method for quantifying cellular uptake of fluorescently labeled siRNA. Journal Of Controlled Release, 20I0. I48(I): p. Io6-Io9.

8. Lin, C., et al., Novel Bioreducible Poly(amido amine)s for Highly Efficient Gene Delivery. Bioconjugate Chemistry, 2007. I8(I): p. I38-I45. 


\section{Appendix}

Determining the molecular weight of poly(amido amine)s by viscosimetry and the influence of molecular

weight on the transfection efficiency

L.J. van $\operatorname{der} A a$

A. Zintchenko

J.F.J. Engbersen

Part of the work described in this chapter was published in: Macromolecular Rapid Communications, 32 (2011) 321-325 


\begin{abstract}
The molecular weight of a polymer carrier system for gene delivery can play an expressive role on the transfection properties. Exact molecular weight determination of non-standard polymers like poly(amido amine)s is however difficult and requires expensive equipment. In this study we show that simple viscosity measurements give good insight in the relative molecular weights of a series of poly(amido amine)s. A calibration series of polymers based on $\mathrm{CBA}$ and $\mathrm{ABOL}(\mathrm{p}(\mathrm{CBA}-\mathrm{ABOL}))$ was synthesized and their number average molecular weight was determined by endgroup analysis with ${ }^{1} \mathrm{H}$ NMR using tert-butyl endgroups. A Mark-Houwink relation was derived from the intrinsic viscosities using this calibration series, which proved to allow for absolute molecular weight determination of similar polymers. The influence of the molecular weight on the silencing efficiency was also studied and it was learned that a minimal molecular weight of $6 \mathrm{~kg} / \mathrm{mol}$ was required for these polymers to form small and positively charged complexes and to obtain gene silencing. Silencing efficiency is constant above this critical minimal molecular weight and cytotoxicity was not observed because of the bioreducibility of the polymers inside the cell.
\end{abstract}

\title{
A.1 Introduction
}

Transfection of exogenous DNA or RNA by polymeric vectors is a complex process. The efficiency is depending on many factors like cationic charge, polyplex size, hydrophobicity of the polymer, architecture of the polymer backbone and molecular weight. The molecular weight is playing an important role in polyplex formation, transfection efficiency and cytotoxicity and therefore it is important to have information about the molecular weight of the polymeric vector in order to obtain a good understanding of newly developed polymers for gene therapy. (Relative) molecular weights of macromolecules are usually determined by gel permeation chromatography, using different columns and different standards. Unfortunately, these sophisticated systems are not always available or suitable for all types of polymers. However, also other techniques are available for molecular weight determination. An easy accessible, low priced, but highly accurate technique is viscosimetry of polymer solutions. Ubbelohde viscosimetry allows for the determination of the intrinsic viscosity, which is related to the molecular weight of a polymer. The intrinsic viscosity is a perfect tool to compare molecular weights within a family of polymers on a relative base, providing that it is measured under the same conditions. Also absolute molecular weights can be derived from the intrinsic viscosities using the Mark-Houwink relation. However, when developing new polymers, the required constants are not known and have to be determined first from a calibration series of polymers with a known molecular weight.

188 - Appendix A 
In literature, Mark-Houwink constants can be found for many types of frequently used polymers, but to our knowledge no references are published concerning poly(amido amine)s. Therefore, we have synthesized a series of copolymers from $\mathrm{N}, \mathrm{N}$ cystaminebisacrylamide (CBA) and 4-amino-I-butanol (ABOL) polymers (p(CBA-ABOL)) of different molecular weights, which served as calibration polymers to determine a Mark-Houwink relation. The poly(amido amine) $\mathrm{p}(\mathrm{CBA}-\mathrm{ABOL})$ was selected since this is a linear polymer, which is the basis of all investigated polymers in this thesis. Its polymerization reaction easily allows for the synthesis of different molecular weights by termination at different time points. Termination was performed with tert-butylamine to ensure accurate molecular weight determination by ${ }^{1} \mathrm{H}$ NMR endgroup analysis to obtain the number average molecular weight $\left(\mathrm{M}_{\mathrm{n}}\right)$.

As mentioned before, the molecular weight of a polymeric vector is considered an important factor in the transfection efficiency. Systematic studies to the influence of molecular weight on particle formation, nucleic acid protection, transfection efficiency and cytotoxicity were done repeatedly for PEI and chitosan, but were not reported before for poly(amido amine)s. Although systematic studies were predominantly done on pDNA transfections, their results are also of great interest for interpreting molecular weight relations on siRNA applications. Generally, smaller polyplexes were formed with increasing polymer molecular weight for both PEI and chitosan. This is explained by more cooperative interactions from longer polycations combined with a lower loss of translational and rotational entropy of the polymer upon complexation. For PEI it was demonstrated that a molecular weight of at least $2 \mathrm{~kg} / \mathrm{mol}$ was necessary for establishing gene expression [I] and that higher molecular weights generally yielded higher transfection degrees [I-3], although this was highly dependent on the applied polymer/nucleotide ratio [4-5]. However, higher molecular weights are also strongly correlated to an increased cytotoxicity of PEI [I, 4-6]. For chitosan it was also found that polyplex size decreases with increasing molecular weight [7], but there is an optimum of $8 \mathrm{~kg} / \mathrm{mol}$ for gene expression [8]. Lower molecular weight chitosan supplied insufficient complexation power, whereas higher molecular weights lacked sufficient intracellular release of the nucleotides.

It can be expected that the general trends found for PEI and chitosan will also be present in our SS-PAA polymers. However, in the SS-PAA polymers the rapid intracellular reduction, introduced by the presence of the repetitive disulfide linker in the polymer backbone, has shown to be of great influence on the transfection properties [9-Io] and it may be quite possible that this property will overrule more subtle effects caused by differences in molecular weight. In order to elucidate whether differences in molecular weight play a role of significance on siRNA particle formation, gene silencing and cytotoxicity, the $\mathrm{p}(\mathrm{CBA}-\mathrm{ABOL})$ calibration polymers with different molecular weights were also used to evaluate these properties. 


\section{A.2 Methods}

\section{A.2.1 Polymer synthesis}

All chemicals and reference materials, 4-amino-I-butanol (ABOL, Merck), N,N'cystaminebisacrylamide (CBA, Polysciences), tert-butylamine (Sigma-Aldrich) and Lipofectamine 2000 (Invitrogen) were purchased in the highest purity and used without further purification. For culturing the Hi299 Fluct cells, RPMI I640 medium (Lonza) completed with $2 \%(\mathrm{v} / \mathrm{v})$ PennStrepp (Lonza), I\% (v/v) glutamine (Lonza) and Io\% (v/v) fetal bovine serum (Lonza) was used. Negative control siRNA was purchased from Qiagen, anti-luciferase siRNA was kindly supplied by the group of G. Storm from the University of Utrecht. Luciferase assay reagent was obtained from Promega.

\section{A.2.2 Polymer synthesis}

$\mathrm{p}(\mathrm{CBA}-\mathrm{ABOL})$ polymer was synthesized by Michael addition polymerization of 4amino-I-butanol (ABOL) with $N, N$ 'cystaminebisacrylamide (CBA) in presence of calcium chloride as a catalyst [II]. $2.00 \mathrm{~g}(7.7 \mathrm{mmol}) \mathrm{CBA}$ and $0.69 \mathrm{~g}(7.7 \mathrm{mmol}) \mathrm{ABOL}$ were dissolved in $3.85 \mathrm{ml}$ methanol/water $3 / \mathrm{I}(\mathrm{v} / \mathrm{v})$ containing $200 \mathrm{mM}$ of calcium chloride and were allowed to react at $70^{\circ} \mathrm{C}$ in the dark in a nitrogen atmosphere. At regular time intervals, aliquots of $350 \mu \mathrm{l}$ were taken from the polymerization mixture, added to $350 \mu$ tert-butylamine (2.5 eq. with respect to the initial acrylamide content) and stirred at $70^{\circ} \mathrm{C}$ in the dark in a nitrogen atmosphere to terminate the reaction. After $24 \mathrm{~h}$ terminating mixtures were diluted with I M hydrochloric acid and water, purified by ultrafiltration (MWCO Iooo, $\mathrm{pH}_{4}$ ), filtered through a $0.45 \mu \mathrm{m}$ syringe filter and recovered as its $\mathrm{HCl}$ salt by lyophilization. ${ }^{\mathrm{I}} \mathrm{H} \mathrm{NMR}\left(\mathrm{D}_{2} \mathrm{O}\right) \delta(\mathrm{ppm})=\mathrm{I} .33(\mathrm{~s}, 9 \mathrm{H}$, $\left.\left(\boldsymbol{C H}_{3}\right) \mathrm{C}\right) ; \mathrm{I} .58\left(\mathrm{~m}, 2 \mathrm{H}, \boldsymbol{C H}_{2} \mathrm{CH}_{2} \mathrm{NR}\right) ; \mathrm{I} .78\left(\mathrm{~m}, 2 \mathrm{H}, \boldsymbol{C H}_{2} \mathrm{CH}_{2} \mathrm{OH}\right) ; 2.76\left(\mathrm{t}, 4 \mathrm{H}, \boldsymbol{C H}_{2} \mathrm{CONH}\right)$; $2.82\left(\mathrm{t},{ }_{4} \mathrm{H}, \mathrm{CH}_{2} \mathrm{SSC} \boldsymbol{C H}_{2}\right) ; 3.2 \mathrm{I}\left(\mathrm{t}, 2 \mathrm{H}, \mathrm{CH}_{2} \boldsymbol{C H}_{2} \mathrm{NR}\right) ; 3.44$ (t, $\left.4 \mathrm{H}, \boldsymbol{C H}_{2} \mathrm{NR} \boldsymbol{C H}_{2}\right) ; 3.5 \mathrm{I}\left(\mathrm{t},{ }_{4} \mathrm{H}\right.$, $\left.\mathrm{NHCH}_{2} \mathrm{CH}_{2} \mathrm{SSCH}_{2} \mathrm{CH}_{2} \mathrm{NH}\right) ; 3.6 \mathrm{I}\left(\mathrm{t}, 2 \mathrm{H}, \mathrm{CH}_{2} \mathrm{OH}\right)$

\section{A.2.3 Molecular weight determination by NMR}

The number average molecular weight $\left(\mathrm{M}_{\mathrm{n}}\right)$ of the synthesized calibration polymers was calculated from their NMR spectra using the integrated areas of two methylene peaks of the butanol side groups (I.58 ppm and I.78 ppm) and the methyl peak of the tert-butyl endgroup (I.33 ppm). ${ }^{\mathrm{I}} \mathrm{H}$ NMR spectra were recorded on a Varian Innova spectrometer $(300 \mathrm{MHz})$

190 - Appendix A 


\section{A.2.4 Molecular weight determination by GPC}

The molecular weight $\left(\mathrm{M}_{\mathrm{w}}\right)$ of some previously synthesized polymers was measured on a Viscotec GPCmax GPC using acetate buffer (300 mM, pH 4.5) containing 30\% (v/v) methanol as eluent. Molecular weights were determined in an absolute manner, using a TDA 302 triple detector (refractive index, viscosity and right angle light scattering).

\section{A.2.5 Viscosimetry measurements}

Viscosity measurements were performed in an Ubbelohde micro viscosimeter in a thermostated bath at $25^{\circ} \mathrm{C}$. Polymers were dissolved in a sodium acetate buffer (Ioo $\mathrm{mM}, \mathrm{pH}$ 4.5) at a concentration of $5 \mathrm{mg} / \mathrm{ml}$ at least 4 hours before viscosity measurements. Intrinsic viscosities were determined from manually determined elution times of a constant volume through the capillary. If $\eta_{0}$ is the viscosity of the solvent and $\eta$ the viscosity of the polymer with concentration $c$, than these equations can be used to determine the intrinsic viscosity:

$\begin{array}{ll}\text { Relative viscosity: } & \eta_{r}=\frac{\eta}{\eta_{0}}=\frac{t}{t_{0}} \\ \text { Specific viscosity: } & \eta_{s p}=\eta_{r}-1 \\ \text { Reduced viscosity: } & \eta_{r e d}=\frac{\eta_{s p}}{c} \\ \text { Inherent viscosity: } & \eta_{\text {inh }}=\frac{\ln \eta_{r}}{c} \\ \text { Intrinsic viscosity: } & {[\eta]=\lim _{c \rightarrow 0}\left(\eta_{r e d}\right)=\lim _{c \rightarrow 0}\left(\eta_{i n h}\right)=\frac{\sqrt{2\left(\eta_{s p}-\ln \eta_{r e d}\right)}}{c}}\end{array}$

Next the intrinsic viscosity can be used in the Mark-Houwink equation (eq. 6) together with the molecular weight to determine the parameters $\mathrm{K}$ and a:

$$
[\eta]=K \cdot M^{a}
$$

\section{A.2.6 Polyplex preparation}

Polyplexes were prepared in HBG (HEPES buffered glucose: 20 mM HEPES, pH $7.4,5 \mathrm{wt} \%$ glucose) in a polymer/siRNA weight ratio of $48 / \mathrm{I}$. The polymer solution was added to the siRNA solution in a volume ratio of $4 / \mathrm{r}$, followed by $5 \mathrm{~s}$ vortexing and 30 min incubation at room temperature. 


\section{A.2.7 Polyplex properties}

Polyplexes containing $6.25 \mu \mathrm{g} / \mathrm{ml}$ siRNA were prepared as described above. The hydrodynamic diameter and the $\zeta$-potential were measured by dynamic light scattering on a Zetasizer Nano ZS (Malvern Instruments) at $25^{\circ} \mathrm{C}$.

\section{A.2.8 In vitro gene silencing}

Knockdown efficiency was determined by silencing luciferase expression in $\mathrm{NCl}-$ Hi299 cells, stably expressing firefly luciferase. Knockdown and cell viability were evaluated in two parallel sessions, using anti-luciferase and non-coding siRNA, respectively. Cells were seeded in 96 well plates with a density of 8000 cells per well. After $24 \mathrm{~h}$ incubation at $37^{\circ} \mathrm{C}$ in a humidified atmosphere containing $5 \% \mathrm{CO}_{2}$, medium was replaced with Ioo $\mu$ fresh medium without FBS. Polyplexes containing $6.25 \mu \mathrm{g} / \mathrm{ml}$ siRNA at were prepared as described above. Lipofectamine 2000 was used as a reference and complexes were prepared according to the manufacturer's protocol. Polyplexes (20 $\mu \mathrm{l}$ per well) were added to the cells in quinto after I hour incubation with fresh medium, resulting in a final siRNA concentration of $66 \mathrm{nM}$. After 2 hours of transfection, polyplex medium was replaced by complete culture medium and the cells were incubated for another 48 hours. Cells were lysed in a freeze/thaw cycle and $25 \mu \mathrm{l}$ of the cell lysate was mixed with $50 \mu \mathrm{l}$ luciferase assay reagent containing the substrate luciferin. After Ioo - 220 seconds (in this timeframe the emitted light is constant - data not shown) the luciferase activity was determined by measuring the luminescence at $25^{\circ} \mathrm{C}$ for 4 seconds on a PerkinElmer I 420 Victor ${ }^{3}$ plate reader. Luciferase activity of cells treated only with HBG was defined as Ioo\% expression.

\section{A.3 Results and discussion}

$\mathrm{p}(\mathrm{CBA}-\mathrm{ABOL})$ polymers were synthesized by Michael addition polymerization of an equimolar mixture of $\mathrm{CBA}$ and $\mathrm{ABOL}$. At various time intervals aliquots of the reaction mixture were terminated with an excess of tert-butylamine in order to obtain a series of calibration polymers with an increasing molecular weight. It was assumed that before termination the reaction mixture consisted of oligomers containing on average one acrylamide and one secondary amine endgroup. Although the basicity and also the nucleophilic reactivity is in general higher for secondary than for primary amines, the reaction of the secondary amines onto the acrylamide moiety is considered to be the rate determining step, because of the higher sterically hindered reaction site. Furthermore, tert-butylamine was expected to react only once in the termination reaction, because of the hindering tert-butyl group and also the high molar excess that 
was added. Taking these considerations into account, the terminated polymer solely exists of polymer chains containing statistically on average one tert-butyl endgroup. This allows for molecular weight determination by NMR based on the peak area of this endgroup relative to the areas of two methylene peaks from the butanolic side chain (Figure A.I). Even at the highest molecular weight the relative high integration peak originating from the nine protons of the tert-butyl group ensured an accurate molecular weight calculation.

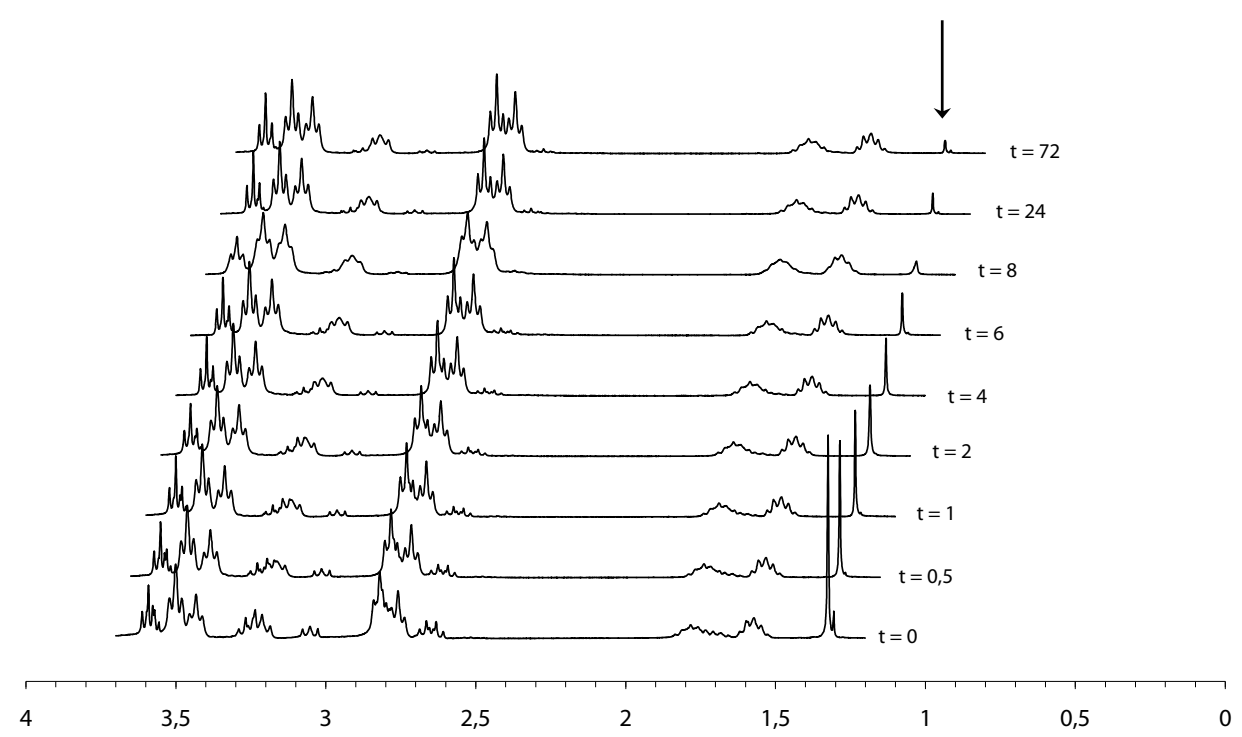

Figure A.1: ${ }^{1} \mathrm{H}$ NMR spectra of the $\mathrm{p}(\mathrm{CBA}-\mathrm{ABOL})$ calibration polymers. The arrow is indicating the specific tert-butyl endgroup peak at $1.33 \mathrm{ppm}$, which was used for molecular weight determination

The resulting molecular weights are plotted as a function of polymerization time in Figure A.2. After eight hours of polymerization the increase of the chain length starts to level off due decreasing in reactive group concentration and a lower mobility of the reactive sites due to increasing viscosity of the reaction solution. It is therefore not expected that polymerizations longer than three days will result in substantial higher molecular weights.

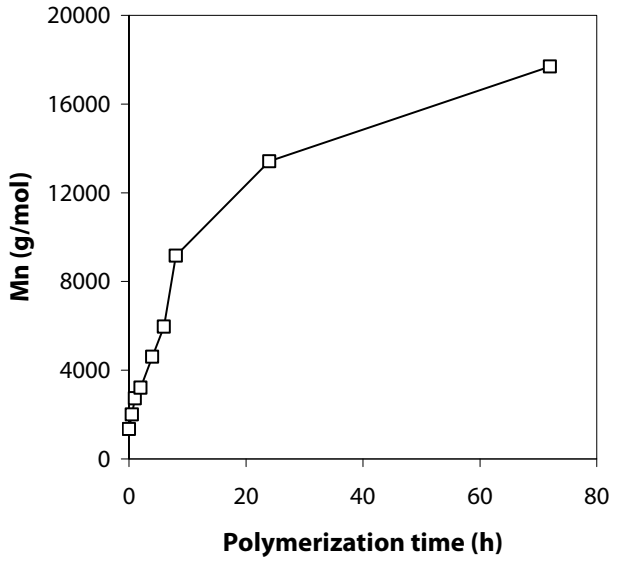

Figure A.2: Molecular weights of $p(C B A-A B O L)$ calibration polymers a function of the polymerization time. 
The synthesized calibration polymers were used to determine the Mark Houwink parameters of $\mathrm{p}(\mathrm{CBA}-\mathrm{ABOL})$ by capillary viscosity measurements. Viscosimetry of polyelectrolytes is usually done in a salt solution. Added salt ions compensate local effects of osmotic pressure near the polymer coil, caused by partial dissociation of the ionic groups at high concentrations, as well as coulomb repulsion forces by shielding the dissociated ionic groups at low concentrations. The addition of salts allows for an extrapolation of the reduced viscosity to zero and the determination of the intrinsic viscosity. To account for these interactions a strong Ioo $\mathrm{mM}$ acetate buffer was selected with a $\mathrm{pH}$ of 4.5. This $\mathrm{pH}$ was considered low enough for complete protonation of the polymer, but high enough to prevent acid catalyzed hydrolysis of the amide bonds. To verify if intramolecular interactions were indeed eliminated in the used buffer, the reduced viscosity of a $\mathrm{p}(\mathrm{CBA}-\mathrm{ABOL})$ polymer was plotted against the concentration (Figure A.3a) and the resulting linear plot confirms that this is the case. For the sake of completeness also the inherent viscosity is plotted in Figure A.za. Extrapolation to zero concentration converges to in an intercept of 0.13 for both lines, which is in accordance with the definition of the intrinsic viscosity and emphasizes once more that the used conditions are suitable for molecular weight determinations.

Subsequently, the intrinsic viscosities of the $\mathrm{p}(\mathrm{CBA}-\mathrm{ABOL})$ calibration polymers were determined and plotted against their molecular weight in a double logarithmic plot (Figure A.3b) to determine the Mark Houwink parameters using eq. 6. These parameters can be used for molecular weight determination of similar $\mathrm{p}(\mathrm{CBA}-\mathrm{ABOL})$ polymers by using viscosimetry.
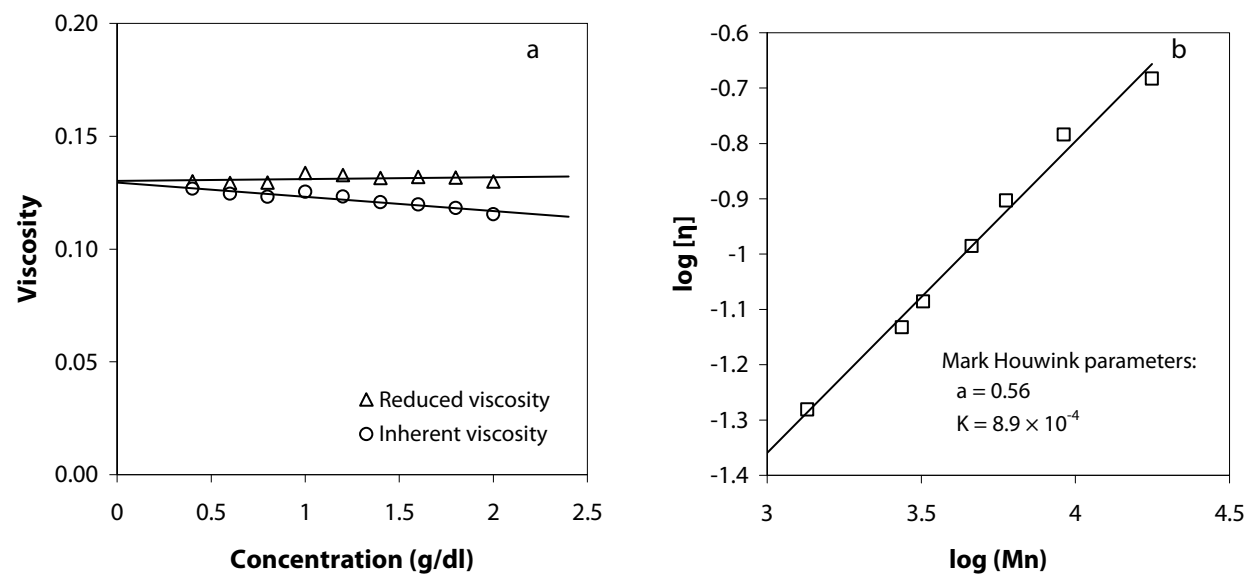

Figure A.3: The reduced and inherent viscosity of $\mathrm{p}(\mathrm{CBA}-\mathrm{ABOL})$ as a function of its concentration to validate that intramolecular interactions in the polymer coils are eliminated in the used buffer (100 $\mathrm{mM}$ acetate, $\mathrm{pH} 4.5)$ (a) and the intrinsic viscosity of the calibration polymer solutions as function of their molecular weights to determine the Mark Houwink parameters of $p(C B A-A B O L)(b)$. 
As a final check on the usability of the obtained Mark-Houwink relation, the intrinsic viscosity was determined from two types of disulfide-based poly(amido amine)s, which molecular weights were determined previously on a GPC system in an absolute manner (Table A.I). The molecular weight for $\mathrm{p}(\mathrm{CBA}-\mathrm{ABOL})$ calculated from the intrinsic viscosity is approximately I.5 times higher than the value determined by GPC. It is not clear if the molecular weights determined by NMR are overestimated or that the GPC determined molecular weights are underestimated. Although the polymers were extensively dried over phosphorus pentoxide before GPC measurements, the polymers are very hygroscopic and the possibility of traces of water in the sample cannot be ruled out and may explain (part of) the difference. Two other batches of this polymer (Table A.I: \#2 and \#3) were also included in the viscosimetry measurements. The resulting molecular weights are also slightly higher than those observed for the calibration polymers. A reason for this may be that these polymers were terminated with a lower excess of ABOL (o.I eq) instead of a large excess of tert-butylamine, allowing for some further polymerization to consume the last acrylamides.

Table A.1: Comparison molecular weights determined by GPC and viscosimetry of previously synthesized SSPAAs.

\begin{tabular}{|c|c|c|c|c|c|c|}
\hline \multirow[b]{2}{*}{ Exp. } & \multirow[b]{2}{*}{ Polymer } & \multicolumn{3}{|c|}{ GPC measurements } & \multicolumn{2}{|c|}{ Viscosity measurements } \\
\hline & & $\begin{array}{l}M_{n} \\
(\mathrm{~kg} / \mathrm{mol})\end{array}$ & $\begin{array}{l}M_{w} \\
(\mathrm{~kg} / \mathrm{mol})\end{array}$ & PDI & $\begin{array}{l}\text { [n] } \\
(d \mathbf{d} / g)\end{array}$ & $\begin{array}{l}M_{n}{ }^{a} \\
(\mathrm{~kg} / \mathrm{mol})\end{array}$ \\
\hline$\# 1$ & $\mathrm{p}(\mathrm{CBA}-\mathrm{ABOL})$ & 21 & 20 & 1.06 & 0.31 & 33 \\
\hline$\# 2$ & $\mathrm{p}(\mathrm{CBA}-\mathrm{ABOL})$ & - & - & - & 0.25 & 23 \\
\hline \#3 & $\mathrm{p}(\mathrm{CBA}-\mathrm{ABOL})$ & - & - & - & 0.28 & 27 \\
\hline$\# 4$ & $\mathrm{p}\left(\mathrm{CBA}-\mathrm{ABOL}_{75} / \mathrm{EDA}_{25}\right)$ & 39 & 38 & 1.03 & 0.58 & 99 \\
\hline
\end{tabular}

(a) Calculated from the intrinsic viscosity using the Mark Houwink constants of $p(C B A-A B O L)$.

The intrinsic viscosity of a previously synthesized $\mathrm{p}\left(\mathrm{CBA}-\mathrm{ABOL}_{75} / \mathrm{EDA}_{25}\right)$ was also included in Table A.I (\#4) and is higher than the intrinsic viscosities measured for $\mathrm{p}(\mathrm{CBA}-\mathrm{ABOL})$ polymers. The corresponding molecular weight, calculated with the Mark-Houwink constants of $\mathrm{p}(\mathrm{CBA}-\mathrm{ABOL})$ is however much higher and even unrealistic with respect to the previously obtained GPC values. The degree of coil expansion of a polymer in solution, which determines the viscosity, is not only depending on the molecular weight, but also depends on chain rigidity which is related with the degree of protonated groups in the polymer. In a fully protonated state the charge density of $\mathrm{p}(\mathrm{CBA}-\mathrm{ABOL} / \mathrm{EDA})$ is higher and the stronger intramolecular charge repulsion increases the extended state of the polymer chains. Furthermore, the two amino groups of EDA, which are both protonated according to the titration curve of $\mathrm{p}\left(\mathrm{CBA}-\mathrm{ABOL} \mathrm{L}_{80} / \mathrm{EDA}_{20}\right)$ in chapter 3 , are in so close vicinity to each other that the 
backbone conformation at this point is largely fixed, as was observed by Kataoka for other EDA containing polymers before [I2]. It is expected that this makes the polymer coils even stiffer, resulting in an even more increased intrinsic viscosity [I3]. These arguments show that the obtained Mark-Houwink relation is only valid for the $\mathrm{p}(\mathrm{CBA}-$ $\mathrm{ABOL})$ polymers.

The synthesized calibration polymers were also used to evaluate the relation between molecular weight of the polymer and the size and surface potential of their polyplexes. The polymers were complexed with siRNA at a polymer/siRNA weight ratio of $48 /$. This ratio was selected, since $\mathrm{p}(\mathrm{CBA}-\mathrm{ABOL})$ usually forms well-defined particles at this ratio (Chapter 3 ). Below $5 \mathrm{~kg} / \mathrm{mol}$, the size of the polyplexes is highly dependent on the molecular weight of the polymer, resulting in smaller polyplexes for longer polymers (Figure A.4a), as was observed before on chitosan/pDNA polyplexes [7]. Polymer molecular weights higher than $5 \mathrm{~kg} / \mathrm{mol}$, do not seem to have any influence on the size of the polyplexes and diameters of around roo $\mathrm{nm}$ were obtained. $\zeta$-Potentials between 20 and $30 \mathrm{mV}$ are generally observed for polyplexes formed of polymers longer than $5 \mathrm{~kg} / \mathrm{mol}$ (Figure A.4b), which correlates quite well with the small polyplex diameters of around Ioo $\mathrm{nm}$. Lower $\zeta$-potentials were observed for polymers smaller than $5 \mathrm{~kg} / \mathrm{mol}$ and are associated with larger particle sizes, indicating poorer nucleotide complexation.
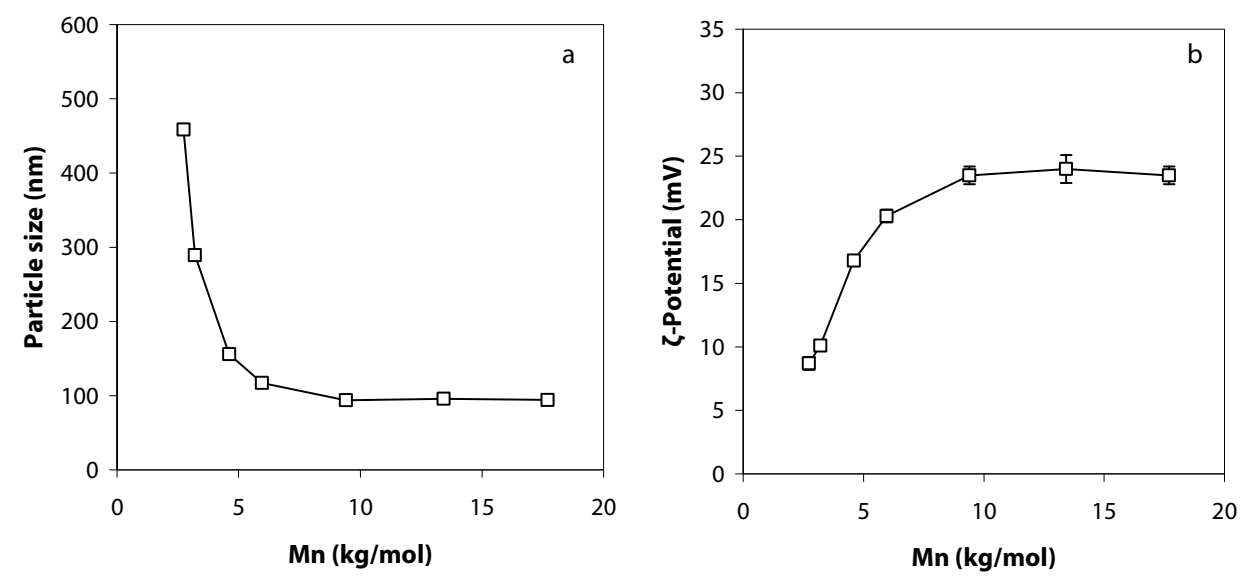

Figure A.4: Particle properties of polyplexes formed from the calibration polymers with siRNA measured by dynamic light scattering: particle size (a) and ל-potential (b). All polyplexes are formed at a 48/1 w/w ratio.

To test if there is also an effect of molecular weight on transfection properties, Hi299 cells were transfected with siRNA against luciferase. In Figure A.5 the luciferase 
silencing properties of polyplexes prepared from the calibration polymers at a polymer/siRNA weight ratio of $48 / \mathrm{r}$ are presented. There is no significant silencing for polymers with molecular weights up to $6 \mathrm{~kg} / \mathrm{mol}$. Above $6 \mathrm{~kg} / \mathrm{mol}$, silencing values of around $40 \%$ (60\% remaining luciferase expression) are observed and there is no significant increase in silencing potential at increasing molecular weights. Although the composition of cell culture medium is different from the HBG solution used in the DLS measurements, it is notable that only silencing is observed for small and positively charged polyplexes. It is not assured that the particle properties are the same in the saltcontaining cell culture medium, but these measurements are at least indicating that siRNA is inadequately complexed by the low molecular weight polymers, resulting in absence of silencing capacity. Thus in the measured range of molecular weights between 6 and I $8 \mathrm{~kg} / \mathrm{mol}$, where small and stable particles are formed, the differences in molecular weight have no effect on the silencing potential.

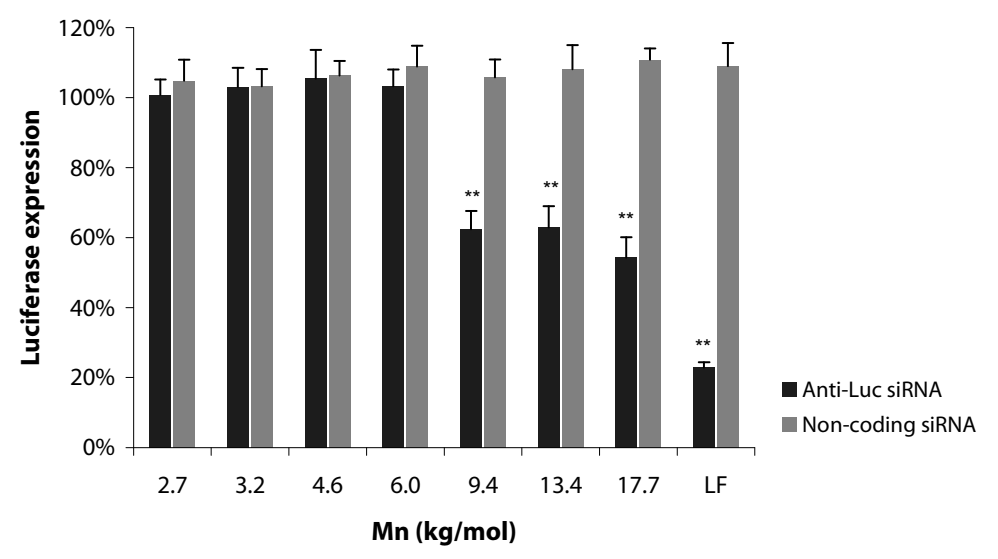

Figure A.5: Luciferase expression of H1299 Fluct cells 48 hours after transfection with anti-luciferase siRNA (black) and non-coding control siRNA (grey) with the calibration polymers. A polymer/siRNA weight ratio of 48/1 was applied and Lipofectamine 2000 (LF) was used as reference transfection agent. Each bar value represents the mean $\pm S D$ of $n=3,4$ or 5 . For statistical analysis of differences between anti-luciferase and non-coding siRNA an unpaired Student's t-test was used $(* * p<0.01)$.

These results obtained here are not completely in agreement with trends published about other polymers like PEI and chitosan. At higher molecular weights PEI is generally found to be more effective, but also more toxic [I, 4-5, I4], caused by the high charge density. Although chitosan is not toxic at high molecular weight, polyplexes from this polymer are dealing with a poor intracellular decomplexation, resulting in low transfection [8]. p(CBA-ABOL) does not suffer from these problems at high molecular weight: no molecular weight upper limit, neither cytotoxicity was observed, which is believed mainly to originate in its intracellular reducible character. Disulfide reduction 
lowers cytotoxicity by avoiding intracellular accumulation of polycations and increases the bioavailability of the contents of the carrier [15-I8]. Although disulfides were applied frequently in PEI formulations to limit the cytotoxicity of PEI [I9-20], Yu et al. showed that reducible branched PEI does not eliminate cytotoxicity completely, but for p(CBA$\mathrm{ABOL}$ ) cytotoxicity was never observed [2I]. It is plausible that the type and the position of the cationic charge also influence the cytotoxicity of the (degraded) polymer. The charge density is much higher for PEI fragments than for $\mathrm{p}(\mathrm{CBA}-\mathrm{ABOL})$ fragments. Finally, $\mathrm{p}(\mathrm{CBA}-\mathrm{ABOL})$ contains only tertiary amines, while branched $\mathrm{PEI}$ also possesses secondary and primary amines, of which especially the latter are considered to induce significant toxicity [22].

\section{A.4 Conclusions}

In this study we have shown that simple viscosity measurements give good insight in the relative molecular weights in a homologous series of poly(amido amine)s. A Mark-Houwink relation was established for $\mathrm{p}(\mathrm{CBA}-\mathrm{ABOL})$ allowing for absolute molecular weight determination of similar polymers. It was found that a minimal molecular weight of $6 \mathrm{~kg} / \mathrm{mol}$ was required to form small and positively charged complexes with siRNA and to obtain gene silencing. Silencing efficiency is constant above this critical minimal molecular weight and cytotoxicity was not observed because of the bioreducibility of the polymer inside the cell. It is expected that higher molecular weights than currently investigated will not change these characteristics and that other SS-PAAs possess similar molecular weight relations, with each type of polymer having its own critical molecular weight.

\section{A.5 References}

I. Breunig, M., et al., Gene delivery with low molecular weight linear polyethylenimines. Journal Of Gene Medicine, 2005. 7(10): p. 1287-1298.

2. $\quad \mathrm{Yu}, \mathrm{H} . \mathrm{J} ., \mathrm{V}$. Russ, and E. Wagner, Influence of the Molecular Weight of Bioreducible Oligoethylenimine Conjugates on the Polyplex Transfection Properties. Aaps Journal, 2009. II(3): p. 445-455.

3. Godbey, W.T., K.K. Wu, and A.G. Mikos, Size matters: Molecular weight affects the efficiency of poly(ethylenimine) as a gene delivery vehicle. Journal of Biomedical Materials Research, 1999. 45(3): p. 268-275.

4. Kunath, K., et al., Low-molecular-weight polyethylenimine as a non-viral vector for DNA delivery: comparison of physicochemical properties, transfection efficiency and in vivo distribution with high-molecular-weight polyethylenimine. Journal Of Controlled Release, 2003. 89(I): p. II3-I25.

$198 \cdot$ Appendix A 
5. Fischer, D., et al., A novel non-viral vector for DNA delivery based on low molecular weight, branched polyethylenimine: Effect of molecular weight on transfection efficiency and cytotoxicity. Pharmaceutical Research, I999. 16(8): p. I273-I279.

6. Breunig, M., et al., Breaking up the correlation between efficacy and toxicity for nonviral gene delivery. Proceedings of the National Academy of Sciences of the United States of America, 2007. I04(36): p. I4454-I4459.

7. $\quad$ Lavertu, M., et al., High efficiency gene transfer using chitosan/DNA nanoparticles with specific combinations of molecular weight and degree of deacetylation. Biomaterials, 2006. 27(27): p. 4815-4824.

8. Strand, S.P., et al., Molecular design of chitosan gene delivery systems with an optimized balance between polyplex stability and polyplex unpacking.

Biomaterials, 20I0. 3I(5): p. 975-987.

9. Lin, C., et al., Linear poly(amido amine)s with secondary and tertiary amino groups and variable amounts of disulfide linkages: Synthesis and in vitro gene transfer properties. Journal of Controlled Release, 2006. II6(2): p. I30-I37.

Io. Piest, M., et al., Novel poly(amido amine)s with bioreducible disulfide linkages in their diamino-units: Structure effects and in vitro gene transfer properties. Journal of Controlled Release, 2008. I30(I): p. 38-45.

II. Zintchenko, A., L.J. van der Aa, and J.F.J. Engbersen, Improved Synthesis Strategy of Poly(amidoamine)s for Biomedical Applications: Catalysis by "Green" Biocompatible Earth Alkaline Metal Salts. Macromolecular Rapid Communications, 20I0: p. Accepted manuscript.

I2. Miyata, K., et al., Polyplexes from Poly(aspartamide) Bearing I,2Diaminoethane Side Chains Induce pH-Selective, Endosomal Membrane Destabilization with Amplified Transfection and Negligible Cytotoxicity. Journal of the American Chemical Society, 2008. I30(48): p. I6287-16294.

I3. Kulicke, W.-M. and C. Clasen, Viscosimetry of polymers and polyelectrolytes. Springer laboratory. 2004, Berlin ; New York: Springer. xvii, I20 p.

I4. Grayson, A.C.R., A.M. Doody, and D. Putnam, Biophysical and structural characterization of polyethylenimine-mediated siRNA delivery in vitro. Pharmaceutical Research, 2006. 23(8): p. I868-1876.

I5. Bauhuber, S., et al., Delivery of Nucleic Acids via Disulfide-Based Carrier Systems. Advanced Materials, 2009. 2I(32-33): p. 3286-3306.

I6. Manickam, D.S., et al., Effect of innate glutathione levels on activity of redoxresponsive gene delivery vectors. Journal Of Controlled Release, 20IO. I4I(I): p. 77-84.

I7. Lin, C. and J.F.J. Engbersen, The role of the disulfide group in disulfide-based polymeric gene carriers. Expert Opinion on Drug Delivery, 2009. 6(4): p. 42I439 .

I8. Thomas, C.E., A. Ehrhardt, and M.A. Kay, Progress and problems with the use of viral vectors for gene therapy. Nature Reviews Genetics, 2003. 4(5): p. 346358.

I9. Lee, Y., et al., Visualization of the degradation of a disulfide polymer, linear poly(ethylenimine sulfide), for gene delivery. Bioconjugate Chemistry, 2007. I8(I): p. I3-I8. 
20. Breunig, M., et al., Mechanistic investigation of poly(ethylene imine)-based siRNA delivery: Disulfide bonds boost intracellular release of the cargo. Journal of Controlled Release, 2008. 130(I): p. 57-63.

21. Lin, C., et al., Novel Bioreducible Poly(amido amine)s for Highly Efficient Gene Delivery. Bioconjugate Chemistry, 2007. I8(I): p. I38-I45.

22. Fischer, D., et al., In vitro cytotoxicity testing of polycations: influence of polymer structure on cell viability and hemolysis. Biomaterials, 2003. 24(7): p. II2I-II3I. 


\title{
Appendix
}

\author{
Summary
}

Nederlandse samenvatting

Curriculum Vitae 


\section{Summary}

This thesis describes the development and optimization of novel bioreducible poly(amido amine) copolymers (SS-PAAs) for delivery of siRNA. Structure-function relations on physico-chemical properties, gene delivery, transfection capability, and cytotoxicity are discussed in detail.

A general background with regard to the work in this thesis and to RNA interference (RNAi) is provided in Chapter 1. In Chapter 2 the complete route from siRNA complexation to in vivo delivery of siRNA with the use of polymeric carriers is described and extensively illustrated with examples from recent scientific literature. In Chapter 3 SS-PAA copolymers were synthesized with tunable charge densities to obtain optimal interaction with short siRNA molecules. The polymers were synthesized by Michael addition polymerization of $N, N^{\prime}$-cystaminebisacrylamide (CBA) with variable ratios of 4-amino-I-butanol (ABOL) and ethylene diamine (EDA) or triethylenetetramine (TETA). It was observed that at least $20-30 \%$ EDA or TETA amino units in the copolymers is necessary to encapsulate siRNA into small and stable polyplexes. Copolymers with $20 \%$ EDA showed excellent gene silencing properties in vitro in Hi299 cells with negligible cytotoxicity. Incorporation of higher amounts of EDA or TETA in the copolymers did not further improve polyplex formation and stability, but the increased cationic charge density in these copolymers resulted in increased cytotoxicity and hemolytic activity of the polymer. The charge density in the $\mathrm{p}$ (CBA-ABOL/EDA) copolymer was further optimized in Chapter 4 for optimal performance of this cationic polymer in gene silencing. It was found that the optimal EDA content is between 20 and $30 \mathrm{~mol} \%$, since lower amounts of EDA resulted in lower silencing in Hi299 cells, whereas higher EDA contents only increased cytotoxicity. Parallel to a proper charge density a good balance between hydrophilic and lipophilic properties of polymeric gene vectors is known to contribute positively to the transfection efficiency. In Chapter 5 the alkyl chain length of the $\omega$-hydroxyalkyl side chains in $\mathrm{p}(\mathrm{CBA}-\mathrm{ABOL} / \mathrm{EDA})$ was varied to optimize gene silencing by finding an optimal balance in hydrophilicity and lipophilicity. It was found that the chain length does not significantly affect particle formation and gene knockdown, but has profound influence on the cytotoxicity and hemolysis of the polymer. The existing hydroxybutylcontaining polymer $\mathrm{p}(\mathrm{CBA}-\mathrm{ABOL} / \mathrm{EDA})$ appeared to be best candidate, since it showed excellent gene silencing properties combined with negligible cytotoxicity. This polymer was finally selected for further research on post-modification of siRNA containing polyplexes in the next two chapters. In Chapter $\mathbf{6}$ a pyridyl disulfide containing monomer (PDA) was synthesized to introduce thiol reactive sidegroups in the $\mathrm{p}(\mathrm{CBA}$ ABOL/EDA) copolymer. The PDA sidegroups were used for reversible post-crosslinking of polyplexes by a bifunctional thiol molecule in order to improve the long-term

202 - Appendix B 
stability of the polyplexes, which should finally contribute to the development of successful siRNA vectors for in vivo applications. Network formation in the nanoparticles was approved and size and surface potential of siRNA containing polyplexes were not affected by the crosslinking reaction. The crosslinked polyplexes showed lower gene silencing capacity than the non-crosslinked analogues. For high crosslinking degrees, where all the available PDA sidegroups were supposed to be involved in the crosslinking, this could be attributed to complex destabilization induced by a thiol disulfide exchange reaction with disulfide groups in the polymer backbone. For lower tested crosslinking degrees a delay in gene silencing is more likely since more disulfides need to be reduced for siRNA release. A post-PEGylation of PDA functionalized $\mathrm{p}(\mathrm{CBA}-\mathrm{ABOL} / \mathrm{EDA}) / \mathrm{siRNA}$ polyplexes using thiol-functionalized poly(ethylene glycol) (PEG-SH) was investigated in Chapter 7. The PEGylation effectively decreased the surface potential of the polyplexes without influencing the polyplex size. PEGylation also contributed dramatically to the colloidal stability of the polyplexes in physiological salt solutions and provided particles that were stable for more than one month, although stability against the competing polyanion heparin was not apparent. Moreover, nucleolytic degradation of siRNA was also prevented by PEGylation. The gene silencing of $20-30 \%$ obtained by siRNA polyplexes with up to 50 wt\% of PEG was still reasonable in view of the reduction of their surface charges. A new class of SS-PAA carriers for siRNA and pDNA is developed in Chapter 8. A nucleotide specific binding interaction based on intercalation was investigated to improve the polymer/nucleotide complex formation. For this purpose SS-PAAs were synthesized with both butanolic $(\mathrm{ABOL})$ and intercalating quaternary nicotinamide side chains. The presence of the quaternary nicotinamide moieties proved to effectively decrease the size of the complexes and reduce the amount of polymer required for complete encapsulation of both siRNA and pDNA. These polymers showed to be non-hemolytic, even at the maximum degree of nicotinamide moieties in the polymer backbone. Surprisingly, polyplexes with siRNA showed no appreciable gene silencing, but with pDNA excellent gene expression without any notable cytotoxicity was obtained. Polymers with $25 \%$ of nicotinamide in the side chains induced GFP expressions of about 4 - 5 times that of linear PEl. Four reducible poly(amido amine)s containing $75 \%$ of $\mathrm{ABOL}$ and $25 \%$ of structurally related quaternary nicotinamide moieties as side groups for the complexation of siRNA and pDNA were described in Chapter 9. The intercalation interaction was tuned by the use of quaternary nicotinamides that were $\mathrm{N}$ alkylated or $N$-phenylated at the amide functionality. The strongly intercalating quaternary nicotinamide (unsubstituted) and $N$-phenylnicotinamide side groups were found to contribute significantly to the formation of small and cationic polyplexes. Gene silencing was only observed with polyplexes of polymers having the strongest intercalating sidegroup ( $N$-phenylnicotinamide). For gene expression, the ability to 
intercalate turned out to be highly beneficial at low polymer/pDNA ratios, resulting in GFP expressions that were up to sixfold higher than were obtained with linear PEI, in absence of cytotoxicity. The molecular weight of a polymer carrier system for gene delivery can play an expressive role on the transfection properties, but exact molecular weight determination of non-standard polymers like poly(amido amine)s is difficult and requires expensive equipment. In Appendix $\mathbf{A}$ we show that simple viscosity measurements can give good insight in the relative molecular weights of a series of poly(amido amine)s. A calibration series of polymers based on $\mathrm{p}(\mathrm{CBA}-\mathrm{ABOL})$ was synthesized and a Mark-Houwink relation was obtained. Furthermore, it was learned that a minimal molecular weight of $6 \mathrm{~kg} / \mathrm{mol}$ was required for these polymers to form small and positively charged complexes and to obtain gene silencing. Silencing efficiency is constant above this critical minimal molecular weight and cytotoxicity was not observed because of the bioreducibility of the polymers inside the cell. 


\section{Nederlandse samenvatting}

Dit proefschrift beschrijft de ontwikkeling en optimalisatie van nieuwe bioreduceerbare poly(amido amine) copolymeren (SS-PAA's). Structuur-functie verbanden met betrekking tot de fysische en chemische eigenschappen, gen afgifte, transfectie vermogen en cytotoxiciteit worden in detail besproken.

Allereerst wordt er in Hoofdstuk 1 algemene achtergrond informatie gegeven over het werk in dit proefschrift en over RNA interferentie (RNAi). In Hoofdstuk 2 wordt de complete route van siRNA complexering tot in vivo afgifte met behulp van polymeren beschreven, rijkelijk geillustreerd met voorbeelden uit de recente wetenschappelijke literatuur. In Hoofdstuk 3 zijn SS-PAA copolymeren gesynthetiseerd met verschillende ladingsdichtheden om de interactie met de korte siRNA moleculen te optimaliseren. Deze polymeren zijn gesynthetiseerd in een Michael additie polymerisatie uit $N, N^{\prime}$ cystaminebisacrylamide (CBA) met 4-amino-I-butanol (ABOL) en ethyleendiamine (EDA) of triethyleentetramine (TETA), in variërende verhoudingen. Er kwam aan het licht dat de polymeren tenminste $20-30 \%$ EDA of TETA amine eenheden moeten bevatten om siRNA in kleine en stabiele polyplexen te kunnen verpakken. Het copolymeer met $20 \%$ EDA vertoonde uitstekende gen repressie eigenschappen in vitro in Hi299 cellen met een verwaarloosbare cytotoxiciteit. Het inbouwen van grotere hoeveelheden EDA of TETA in de copolymeren leidde niet tot de vorming van betere en stabielere polyplexen, maar door de verhoogde ladingsdichtheid resulteerde dit wel in zowel een verhoogde cytotoxiciteit als hemolytische activiteit van het polymeer. De ladingsdichtheid van het $\mathrm{p}(\mathrm{CBA}-\mathrm{ABOL} / \mathrm{EDA})$ copolymeer is verder geoptimaliseerd in Hoofdstuk 4. Hier is uit voortgekomen dat het optimale EDA gehalte tussen de 20 en $30 \mathrm{~mol} \%$ ligt. Lagere percentages EDA resulteerden in lagere gen repressie in Hi299 cellen, hogere percentages daarentegen verhoogden enkel de cytotoxiciteit. Naast een goed uitgebalanceerde ladingsdichtheid is het ook bekend dat een goede balans tussen de hydrofiele en de lipofiele eigenschappen van het polymeer positief bijdragen aan de transfectie efficiëntie. Daarom is in Hoofdstuk 5 de lengte van de $\omega$-hydroxyalkyl zijketens van het $\mathrm{p}(\mathrm{CBA}-\mathrm{ABOL} / \mathrm{EDA})$ copolymeer gevarieerd om zo de gen repressie verder te kunnen optimaliseren met het vinden van de optimale balans tussen hydrofiliciteit en lipofiliciteit. We hebben uitgevonden dat de ketenlengte zowel de polyplex vorming als de gen repressie niet significant beïnvloedt, maar dat ze wel grote invloed heeft op de cytotoxiciteit en de hemolytische eigenschappen van het polymeer. Het eerder bestudeerde polymeer met hydroxybutyl zijgroepen (p(CBA-ABOL/EDA)) bleek de beste kandidaat te zijn, aangezien het uitstekende gen repressie eigenschappen vertoonde in combinatie met een te verwaarlozen cytotoxiciteit. In Hoofdstuk $\mathbf{6}$ is er een pyridyldisulfide houdend monomeer (PDA) gesynthetiseerd om zodoende 
thiolreactieve zijgroepen te introduceren in het $\mathrm{p}(\mathrm{CBA}-\mathrm{ABOL} / \mathrm{EDA})$ copolymeer. Deze PDA zijgroepen zijn gebruikt om een reversibele post-vernetting van de polyplexen met behulp van een bifunctioneel thiol molecuul mogelijk te maken. Op deze manier kan de langdurige stabiliteit van de polyplexen verbeterd worden, wat uiteindelijk bijdraagt aan de ontwikkeling van succesvolle siRNA drager systemen voor in vivo doeleinden. We hebben netwerkvorming in de nanodeeltjes aangetoond, terwijl de vernettingsreactie de grootte en de oppervlakte potentiaal van de siRNA houdende polyplexen ongemoeid liet. De vernette polyplexen vertoonden een lager gen repressie vermogen dan hun niet vernette evenbeelden. Bij de hogere vernettingsgraden, waarbij wordt aangenomen dat alle beschikbare PDA zijgroepen participeren in de vernetting, kan dit toegeschreven worden aan destabilisatie van het complex, veroorzaakt door een thiol-disulfide uitwisselingsreactie met de zwavelbruggen in de polymeerketen. Bij de lagere vernettingsgraden is een vertraging van de gen repressie aannemelijker, doordat meer zwavelbruggen gereduceerd dienen te worden, alvorens het siRNA uit het polyplex kan ontsnappen. Een post-PEGylering van dezelfde PDA gefunctionaliseerde polyplexen met behulp van een thiol-gemodificeerd poly(ethyleen glycol) (PEG-SH) is onderzocht in Hoofdstuk 7. Deze PEGylering verlaagde effectief de oppervlakte potentiaal van de polyplexen, zonder de polyplex grootte te beïnvloeden. PEGylering droeg ook aanzienlijk bij aan de colloïdale stabiliteit van de polyplexen in fysiologische zoutoplossingen. Het leverde deeltjes op die langer dan een maand stabiel bleven, hoewel stabiliteit in aanwezigheid van heparine als concurrerend polyanion niet kon worden aangetoond. Verder werd ook nucleolytische degradatie van siRNA voorkomen door PEGylering. Ook de gen repressie van $20-30 \%$, verkregen met polyplexen die tot 50 gewichtsprocent PEG bevatten, is zeer acceptabel, in het licht van de verlaagde oppervlakte potentiaal. In Hoofdstuk 8 is een nieuwe klasse van SS-PAA dragermaterialen voor siRNA en pDNA ontwikkeld. Een nucleotide specifieke bindingsinteractie, gebaseerd op intercalatie, is onderzocht om de polymeer/nucleotide complex vorming te verbeteren. Voor dit onderzoek zijn SS-PAA's gesynthetiseerd met zowel butanolische $(\mathrm{ABOL})$ als intercalerende quaternaire nicotinamide zijgroepen. De aanwezigheid van quaternaire nicotinamide zijgroepen blijkt de grootte van de polyplexen effectief te verlagen en reduceert tevens de minimale hoeveelheid polymeer, die benodigd is voor complete complexering van zowel siRNA als pDNA. De polymeren waren geenszins hemolytisch, zelfs niet bij de maximale hoeveelheid nicotinamide zijketens. Verrassenderwijs realiseerden de siRNA geladen polyplexen geen noemenswaardige gen repressie, maar werd er met pDNA een uitstekende gen expressie gemeten, zonder enige cytoxiciteit. Polymeren met $25 \%$ nicotinamide in de zijketens bewerkstelligden GFP expressies, vier tot vijf keer zo hoog als lineair poly(ethyleen imine). Vier andere SS-PAA's met $75 \%$ ABOL en $25 \%$ structureel verwante nicotinamides als zijgroep zijn bestudeerd in Hoofdstuk 9 voor de complexering van zowel siRNA als 
pDNA. De intercalatie sterkte werd gevarieerd door middel van $\mathrm{N}$-alkylering of $\mathrm{N}$ fenylering van het quaternaire nicotinamide op de amide functionaliteit. De sterk intercalerende nicotinamide (niet gesubstitueerd) en $N$-fenylnicotinamide zijgroepen droegen significant bij aan de vorming van kleine en kationische polyplexen. Gen repressie werd slechts waargenomen bij polyplexen van polymeren met de sterkst intercalerende zijgroep ( $N$-fenylnicotinamide). Voor gen expressie bleek een groot intercalerend vermogen ook zeer bevordelijk bij lage polymeer/pDNA verhoudingen. Dit resulteerde in GFP expressies zes keer zo groot als verkregen met lineair poly(ethyleen imine) polyplexen, zonder cytotoxiciteit. De moleculaire massa van een dragermateriaal voor gen afgifte kan van grote invloed zijn op de transfectie eigenschappen, maar laat zich vaak lastig exact bepalen in het geval van niet-gangbare polymeren zoals poly(amido amine)s en vergt dure apparatuur. In Appendix A laten we zien dat eenvoudige viscositeitsmetingen een goed beeld kunnen geven van de relatieve molecuulmassa's van een serie poly(amido amine)s. Er is een ijk reeks gemaakt van $\mathrm{p}(\mathrm{CBA}-\mathrm{ABOL})$ en daarmee is de Mark-Houwink relatie van dat polymeer bepaald. Verder werd er gevonden dat een minimale moleculaire massa van $6 \mathrm{~kg} / \mathrm{mol}$ benodigd is voor dit polymeer om kleine kationische polyplexen te vormen en om gen repressie te bewerkstelligen. De repressie efficiëntie is constant boven deze kritieke minimale molecuulmassa en cytotoxiciteit is niet waargenomen, vanwege de bioreduceerbaarheid van de polymeren binnen in de cel. 


\section{Curriculum Vitae}

Hans van der Aa was born on October $3 \mathrm{I}^{\text {st }}$, 1980 in Hengelo $(\mathrm{O})$, The Netherlands and was raised in Twello, The Netherlands. In 1999 he obtained his Gymnasium diploma at 'Gymnasium Apeldoorn' and in the same year he started studying Chemical Engineering with a major in polymer chemistry and biomaterials at the University of Twente, Enschede, The Netherlands. He obtained his propaedeutic degree in 2000 and in 2004 he visited polyMaterials AG in Kaufbeuren, Germany, for a three month internship regarding polyurethane based scaffolds for cartilage regeneration. In spring of 2006 he became his Master of Science and 'Ingenieur's' degree in the research group of prof. dr. J. Feijen at the University of Twente under daily supervision of dr. ir. C. Hiemstra with the research entitled: 'Injectable dextran hydrogels formed by Michael type addition for cartilage regeneration'. After his study he worked one season at the traditional Dutch sailing ship 'Res Nova'. Late 2006, he came back to the University of Twente to join the Biomedical Chemistry group as a Ph.D. candidate. He worked under direct supervision of prof. dr. J.F.J. Engbersen and the results of his research are presented in this thesis. Since April 20II, he works as research scientist for PolyVation BV in Groningen, The Netherlands. 